
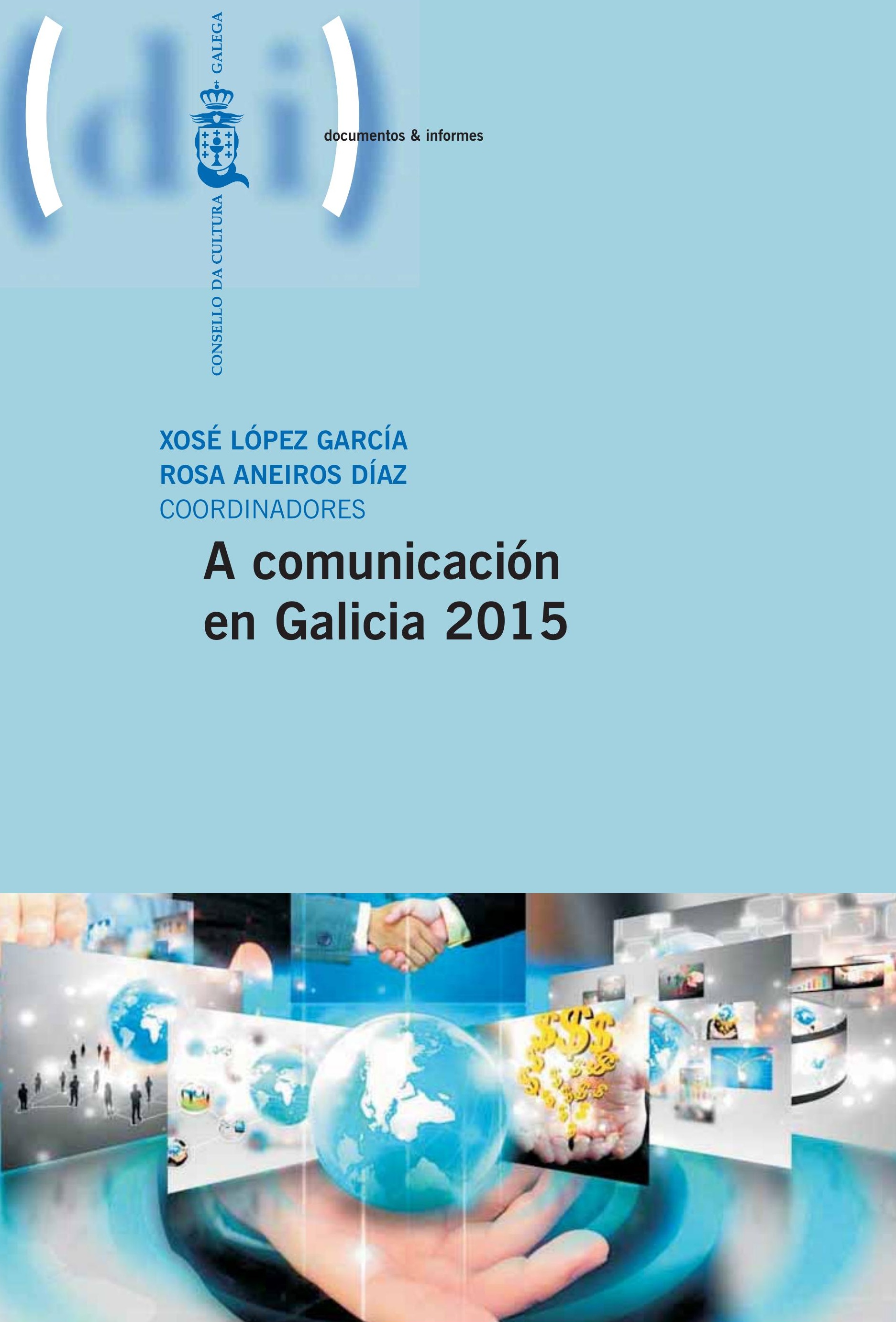

A comunicación en Galicia 2015 
Edita

C) CONSELLO DA CULTURA GALEGA, 2016

Pazo de Raxoi - $2^{0}$ andar · Praza do Obradoiro

15705 - Santiago de Compostela

T $981957202 \cdot$ F 981957205

corre0@consellodacultura.gal

www.consellodacultura.gal

Maquetación

Lugami Artes Gráficas

Proxecto gráfico

Imago Mundi Deseño

Doi:10.17075/aceg.2016 
XOSÉ LÓPEZ GARCÍA ROSA ANEIROS DÍAZ

COORDINADORES

\section{A comunicación en Galicia 2015}

$\stackrel{5}{n}$

CONSELLO

++ DA CULTURA

+ GALEGA $^{+}$ 


\section{Presentación}

Xosé López García, Rosa Aneiros Díaz 


\section{NOS TEMPOS DA ACCESIBILIDADE E A MOBILIDADE}

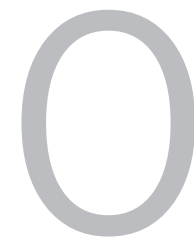

s informes A comunicación en Galicia que periodicamente promove o Consello da Cultura Galega comezan unha nova etapa con esta edición, só en formato dixital, que tenta facer unha aproximación a algúns aspectos da evolución do ecosistema nos últimos anos. Non se trata dunha radiografía de todas as dimensións do ecosistema, senón só dalgunhas arredor das que as e os investigadores das universidades galegas teñen feito traballos e que amablemente aceptaron o convite. Tamén se inclúe un capítulo de novas experiencias no campo da comunicación en galego no que se combinan estudos e iniciativas analizadas por algún dos seus protagonistas. Hai, pois, ausencias, aínda que non esquecementos porque en futuros traballos está previsto analizar aspectos que neste número quedaron fóra.

Se a edición do ano 2013 foi a do vinte aniversario, esta de 2015 representa o primeiro volume dos estudos que nacen nun escenario renovado e marcado pola accesibilidade e a mobilidade. 0 que non mudou foi a liña argumental dos obxectivos que persegue o Consello con esta iniciativa. Trátase, como diciamos na presentación do anterior número, de situar as reflexións no escenario dun mundo conectado por Internet, coa arañeira mundial no centro dos eixes comunicativos e co desafío de estar no mundo en galego e como galegos/as, para o que non só hai que producir mensaxes, senón tamén xestionalas e interactuar. A existencia dunha industria da comunicación propia e de iniciativas cidadás de autocomunicación resultan vitais para asentar esa comunicación con voz propia nun escenario de comunicación caracterizado por unha dobre e simultánea tendencia ao mundial e ao local.

Nesta edición do ano 2015 recóllense traballos de Francisco Campos, que analiza os modelos de negocio; Valentín Alejandro e Óscar Juanatey sobre as perspectivas para a prensa galega en papel; Xosé Ramón Pousa acerca da evolución da radio; Silvia García e Mónica Valderrama arredor da situación do medio televisivo; Miguel Anxo Fernández sobre o cine; Domingo Docampo arredor das infraestruturas de telecomunicacións; Berta García sobre os gabinetes de comunicación online; Alberto Pena arredor da evolución do sector publicitario, e Xosé Baamonde, Iván Puentes e Xosé Rúas sobre as relacións públicas no noso país.

No apartado das novas experiencias no campo da comunicación, Emma Torres reflexiona sobre a perspectiva profesional da formación universitaria en comunicación, con atención ao emprendemento; Carmen Costa analiza as novas estratexias para as industrias da cultura coas iniciativas transmedia e de ludificación; Xaime Fandiño, Zósimo López e Henrique Neira fan unha aproximación ao escenario laboral da industria da música en Galicia, e a xornalista Montse Dopico analiza como facer da necesidade virtude no campo da cultura en Internet.

O conxunto de traballos mostra interesantes achegas de datos e puntos de vista concernentes á evolución do ecosistema comunicativo galego nos tempos da accesibilidade e a mobilidade.

Dende o Consello da Cultura Galega o noso agradecemento a todas e todos os participantes pola súa colaboración. 
0

Índice

U

(0

r

(a 


\section{PRESENTACIÓN}

Xosé López García e Rosa Aneiros Díaz

11 A terceira década dixital Francisco Campos Freire

45 A prensa galega en papel: sen luz ao final do túnel Valentín-Alejandro Martínez-Fernández e Óscar Juanatey-Boga

55 A radio en Galicia 2012-2014: máis emisoras, menos negocio Xosé Ramón Pousa

77 Situación do medio televisivo en Galicia (2012-2014): contexto, audiencia, investimento publicitario, uso do galego e tendencias

Silvia García Mirón e Mónica Valderrama Santomé

89 O cine: Un sector convulso

Miguel Anxo Fernández

99 Internet, sociedade e comunicación en Galicia Manuel Gago, Xosé López e Xosé Pereira

115 As infraestruturas de telecomunicacións Domingo Docampo

129 Os gabinetes de comunicación online en Galicia Berta García Orosa

143 Achega sobre a publicidade en Galicia, 2012-2014 Alberto Pena Rodríguez

153 As relacións públicas en Galicia: estado da comunicación empresarial e institucional Xosé Baamonde-Silva, Iván Puentes-Rivera e Xosé Rúas-Araújo 


\section{NOVAS EXPERIENCIAS NO CAMPO DA COMUNICACIÓN}

167 A perspectiva profesional da formación universitaria en comunicación: iniciativas de emprendemento

Emma Torres-Romay

183 Narrativas transmedia e ludificación. Novas estratexias para as industrias da cultura Carmen Costa-Sánchez

195 Unha aproximación ao escenario laboral da industria da música en Galicia Xaime Fandiño Alonso, Zósimo López Pena e Henrique Neira Pereira

211 A cultura en Internet: facer da necesidade virtude Montse Dopico 


\section{A TERCEIRA DÉCADA DIXITAL}

Francisco Campos Freire

Universidade de Santiago de Compostela

Doi:10.17075/aceg.2016.001 

Dicimos terceira pero, en realidade, pode ser cuarta ou quinta porque o proceso de converxencia dixital se remonta aos últimos vinte anos do pasado século xx se botamos o ollo á xenealoxía da sociedade da información. Pero a idea do titular non é mirar cara a atrás, senón pensar a futuro, é dicir, na próxima terceira década do século XXI. O obxectivo deste traballo é pasar revista á situación actual da estrutura da industria cultural e das políticas institucionais coa perspectiva posta na próxima década que se aveciña. Unha revisión que inevitablemente hai que enmarcar nunha transición dixital que avanza máis rápido que a capacidade de xestión e reacción que teñen as políticas institucionais e as principais empresas tradicionais da prensa, radiotelevisión, audiovisual e produción editorial.

A converxencia dixital é un proceso da sociedade contemporánea que se remonta á orixe das industrias modernas da comunicación (telégrafo, teléfono e audiovisual) ao aproximar tecnoloxías eléctricas e mecánicas e que ten a súa eclosión (Flichy 1982) na confluencia das chamadas novas tecnoloxías da información (informática e telecomunicacións).

Aínda que a noción da converxencia se remonta aos séculos XVIII e XIX (William Derham e Charles Darwin xa a empregaron) e logo ao tránsito da sociedade postindustrial á da información (Brzezinski chámalle tecnotrónica e Negroponte ou John Sculley convértena en tecnoutopía), a dixitalización (que é a tradución da información a díxitos en expresión orixinal básica de Pierre Lévy 2007: 36-37) dálle un novo sentido permitindo a súa compresión, integración multimedia e transmisión.

A converxencia dixital, que se estudou e definiu logo máis amplamente (Jenkins 2006), é unha cultura e un conxunto de procesos de transformación tecnolóxica, económica, organizativa e social que afectan os usuarios (consumidores e audiencias) e os fluxos de información e comunicación así como a case todas as industrias e, especialmente, as culturais. Outro efecto da converxencia é a ruptura da relación física dos contidos cos seus soportes analóxicos, convertendo os produtos en servizos intanxibles, desmaterializando o soporte de lexitimación da transación intelectual e provocando a ruptura dos modelos tradicionais de negocio das industrias culturais.

A revolución dixital transcendeu os ámbitos tecnolóxicos e non só se converteu en interface disruptiva da economía e das industrias tradicionais da cultura, senón tamén nunha especie de paradigma do home novo biotecnolóxico, conectado e prosumer, que Pierre Calmard (2015) retrata no seu ensaio L'homme à venir. Comment le numérique va nous transformer. Polo tanto, a converxencia tecnolóxica non só está afectando os dispositivos que nos rodean, senón tamén as nosas propias vidas.

A revolución da última década do século xx foi a da web (a comunicación a través de Internet), a dos primeiros dez anos do XXı foi a da autocomunicación (a da web social 2.0 e as redes dixitais), a da segunda década é a da Internet das cousas (automatización das comunicacións e da web semántica 3.0) e a da terceira vai ser a da intelixencia artificial (a comunicación intelixente das máquinas, a web 4.0, cos homes).

A biotecnoloxía aspira liberar a mente humana do sobrealmacenamento de datos para poder ampliar a súa capacidade de atención, reacción e multitarefa das persoas. Por iso, Google contrataba en 2012 como director de enxeñaría o científico Ray Kurzweil, experto en comunicación home-máquina. Coa biotecnoloxía «nada impide a creación de novos xéneros, novas formas de representación da especie e da plurisexualidade», segundo imaxina Pierre Calmard (2015) no seu futurista ensaio sobre a revolución dixital. 
Fronte a esas prospectivas futuristas da biotecnoloxía, da apropiación máis intensiva do cerebro e do corpo humano por parte da industria, os cambios no mundo das comunicacións e das plataformas mediáticas xa son reais e actuais. Google, Apple, Facebook ou Amazon son tres veces máis poderosas e teñen maiores ganancias que a empresa de comunicación tradicional máis grande do mundo.

Os medios de comunicación tradicionais, a escala global ou local, enfróntanse a moitos retos ao mesmo tempo: perda de control sobre os seus sistemas de distribución; sobre os seus modelos de negocio e monetización; sobre a capacidade de ser gardiáns editoriais, de reputación e credibilidade; sobre a converxencia, hibridación e confusión da información coa publicidade; sobre a lexitimidade da opinión pública e a súa sustentabilidade; e sobre a adaptación a un proceso radical de novas formas de economía da atención, da afiliación, da pescuda da pegada dixital, da recomendación e colaboración, como describe Michel Bauwens na súa recente obra Sauver le monde, vers une économie post-capitaliste avec le peer-to-peer (2015), que prologa Bernard Stiegler sentenciando que «non vivimos nunha época de cambios, senón nun cambio de época».

A reacción dos medios tradicionais fronte á disrupción da economía dixital é de desconcerto, incerteza e axuste económico para compensar a perda de ingresos que rexistran os seus modelos de negocio da vella economía. 0 dilema non é fácil de resolver porque os modelos de negocio tradicionais están perdendo valor fronte aos da nova economía polo cambio no comportamento dos consumidores e pola alteración nos custos de transación. Debido á dificultade de asumir os cambios disruptivos, a alternativa para os medios tradicionais é a innovación adaptativa (Campos 2015) para a recuperación do valor e a compensación a medio prazo dos vellos e novos modelos de negocio.

A transición da economía analóxica á dixital é complexa pero é inevitable. E, ademais, estase producindo a maior velocidade da que precisan algunhas empresas e industrias para a súa adaptación. Aínda que non é o noso obxectivo facer predicións agoireiras, as análises de tendencias dos tres principais sectores da industria da comunicación -a prensa, o audiovisual e a publicidade- delimitan unha década (2015-2025) de radical transformación. Máis adiante reproducimos datos, estatísticas e gráficas.

\section{A TRANSICIÓN DIXITAL}

As previsións sobre a industria dos medios de comunicación e o entretemento que ofrecen os informes de prospectiva de 2015-2019 de PWC (PricewaterhouseCoopers 2015) e Global Digital Media da Asociación Mundial de Diarios (WNMN 2014) son coincidentes en que o crecemento deste hipersector estará protagonizado nos próximos anos polos servizos dixitais mentres os negocios tradicionais da edición, impresión, audiovisual e publicidade rexistran perdas continuadas nas súas evolucións. Ao resumo dos datos destes informes, seguirán as cifras da nosa pescuda sobre a situación dos medios en Europa, España e Galicia, que tamén son coincidentes coas tendencias de carácter xeral.

A difusión da prensa impresa nos últimos cinco anos foi claramente á baixa, especialmente en Europa, cun descenso xeral situado arredor do 20 \% da súa circulación, como dan conta as cifras ponderadas do informe de 2014 de World Trends da Asociación Mundial de Diarios (WAN-IFRA). Dicimos ponderadas porque as porcentaxes comparativas de 2013 fronte a 2009 só son con respecto a aqueles países dos que hai datos de ambos os anos. E o investimento publicitario é lineal, sen repercusión da inflación. 
Cadro 1. Evolución mundial da prensa impresa

\begin{tabular}{lrrrrrrr} 
Continentes & $\mathbf{2 0 0 8}$ & $\mathbf{2 0 0 9}$ & $\mathbf{2 0 1 0}$ & $\mathbf{2 0 1 1}$ & $\mathbf{2 0 1 2}$ & $\mathbf{2 0 1 3}$ & 2013-2009 \\
\hline África & 9065 & 9581 & 10110 & 12805 & 5583 & 1346 & $-22,34 \%$ \\
\hline Asia & 316981 & 342649 & 344000 & 333945 & 333338 & 66640 & $-0,04$ \\
\hline América & 81722 & 78504 & 76179 & 75258 & 72606 & 15513 & $-1,53$ \\
\hline Europa & 129791 & 117501 & 105956 & 99710 & 91600 & 78640 & $-23,59$ \\
\hline Mundo & 537762 & 548867 & 536880 & 520338 & 504107 & 162139 & $-17,45$ \\
\hline \multicolumn{7}{c}{ Número de cabeceiras } \\
\hline África & 178 & 186 & 185 & 185 & 21 & 21 & 5 \\
\hline Asia & 5626 & 5834 & 5968 & 7336 & 6539 & 708 & 3,82 \\
\hline América & 3240 & 3148 & 3136 & 3136 & 3206 & 2327 & 6,37 \\
\hline Europa & 2383 & 2365 & 2292 & 2296 & 2146 & 1524 & $-10,49$ \\
\hline Mundo & 11427 & 11533 & 11582 & 12926 & 11912 & 4580 & $-5,13$ \\
\hline \multicolumn{7}{c}{ Investimento publicitario } \\
\hline África & 3500 & 3650 & 4220 & 4400 & 4682 & 4381 & 20,02 \\
\hline Asia & 113757 & 114310 & 127825 & 135796 & 140765 & 137414 & 20,21 \\
\hline América & 170210 & 177902 & 186844 & 193329 & 203451 & 212567 & 19,48 \\
\hline Europa & 115785 & 116260 & 122468 & 126294 & 122819 & 121293 & 4,32 \\
\hline Mundo & 403252 & 412123 & 441359 & 459820 & 471718 & 475656 & 15,41 \\
\hline
\end{tabular}

Fonte: elaboración propia con cifras de World Trends WAN-IFRA, 2014. Os datos de difusión son en millóns de exemplares e os de investimento publicitario en millóns de dólares. Os datos de 2013 non están completos na base de WAN-IFRA e por iso a evolución porcentual só se refire á comparación dos países e anos dos que hai cifras homoxéneas. En Asia agréganse os datos de Australia, Oceanía, Turquía e Emiratos Árabes.

Para os próximos cinco anos a previsión de ingresos da prensa segue sendo negativa, cun descenso porcentual situado entre o -0,9 e o-0,7 a partir de 2017, segundo as estimacións de PWC.

Eses descensos afectan tanto os ingresos pola venda de exemplares como por publicidade, a pesar de que aumentará lixeiramente a circulación (de 552,7 millóns de copias en 2014 a 580,7 millóns en 2019), pero a prezos máis reducidos nos mercados dos países emerxentes. China e India, como expresión da alfabetización e das novas economías de consumo, son os países que protagonizarán en 2019 o crecemento e o 57,3% da circulación mundial da prensa.

Outra significativa tendencia é a converxencia das porcentaxes de ingresos por publicidade e circulación, que se ben as primeiras eran maiores (o 54,4 \%) que as segundas en 2010, para o ano 2019 estímase que se igualarán arredor do $50 \%$. Os ingresos pola subscrición dixital (paywall, muro de pago) non compensan aínda os descensos da publicidade e da circulación do sistema tradicional impreso. Estímanse eses ingresos dixitais nunha media de entre o 8 \% e o 12 \% (Picard 2014) da facturación xeral dos xornais, equivalente aínda a un negocio de troco de dólares analóxicos por centavos dixitais (como afirma Mathew Ingram). A monetización dos accesos e transaccións a través do móbil é outra parte do desafío porque a partir de 2017 máis da metade da poboación mundial estará conectada á Internet de mobilidade.

Hai varios estudos e predicións sobre a evolución da prensa en papel. O máis recente con respecto á elaboración deste traballo é un informe -publicado en agosto de 2015- de Ken Goldstein, analista dos negocios de comunicación, acerca da evolución da prensa en Canadá, que rexistra unha caída da súa circulación de pago en máis do 
Cadro 2. Proxección mundial dos ingresos da prensa
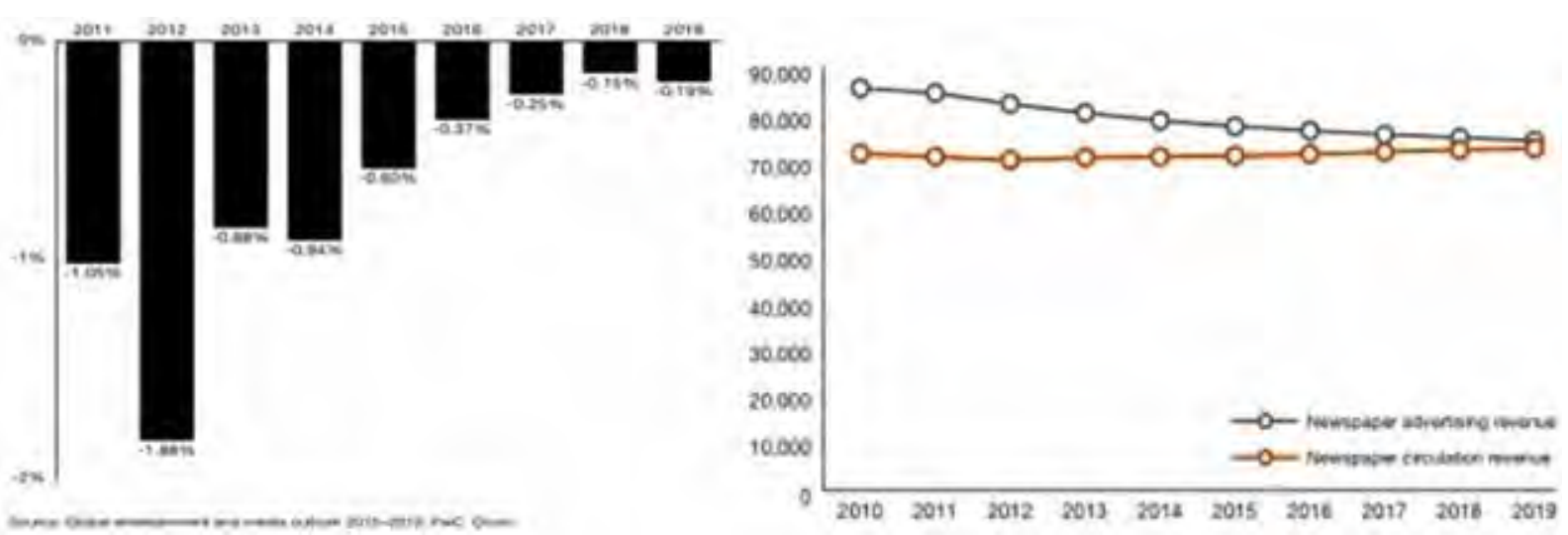

Fonte: PWC 2015. Evolución porcentual dos ingresos da prensa e converxencia das vendas por circulación e publicidade.

20 por cento entre 1995 e 2014 e proxecta a mesma continuidade do desprazamento ata 2025, ano para o que prevé apenas entre un 5 e un 10 por cento de fogares canadenses con xornais impresos, mentres que hai 20 anos esa taxa era dez veces superior. Este analista conclúe que as empresas xornalísticas teñen dez anos por diante para adaptar os seus negocios de información aos modelos de negocio dixitais.

Cadro 3. Proxección da prensa de Canadá, 1995-25
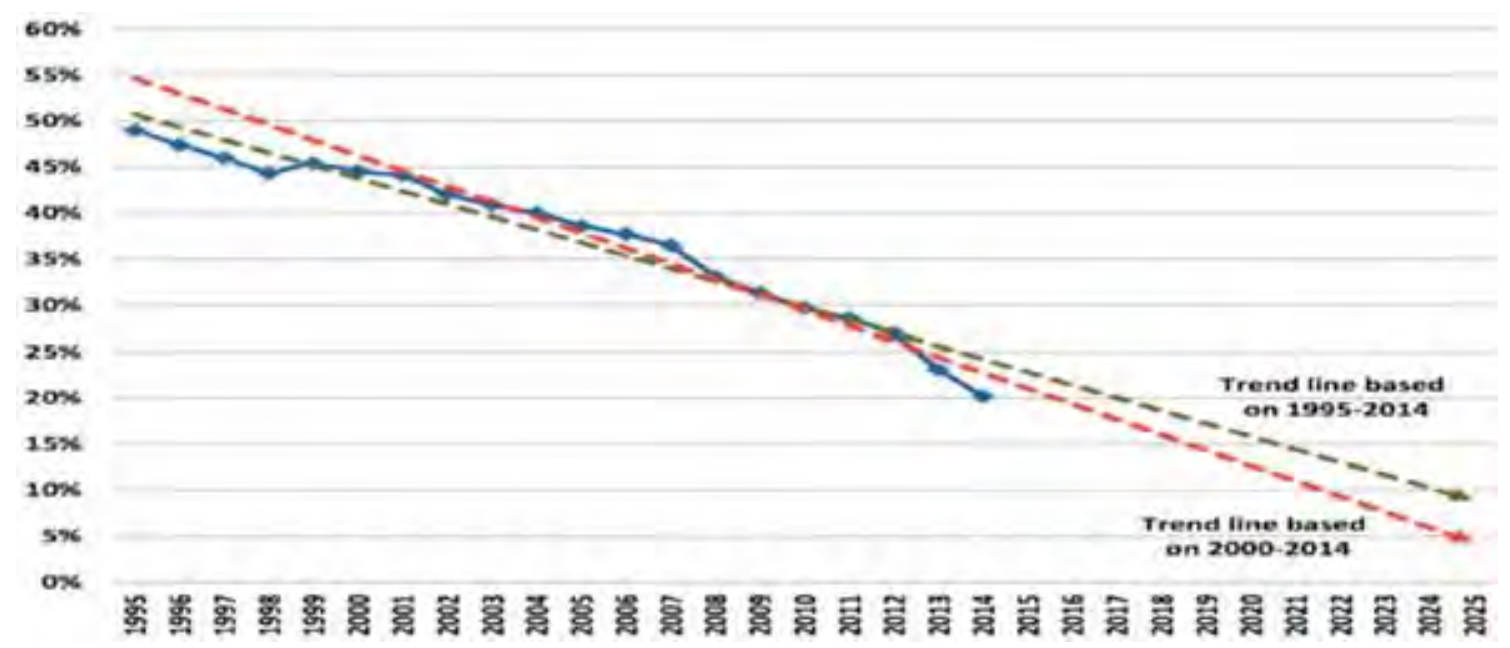

O comportamento global da migración na industria do libro en papel é semellante ao da prensa, manténdose nos países de alfabetización recente e adaptándose aos ecosistemas dixitais no resto do mundo occidental, aínda que con conxunturais fluxos e refluxos, coma no caso de España en 2014 (medrou a impresión fronte ao dixital). A da música foi a primeira que sufriu a transformación. Se a crise das industrias da impresión (nos soportes de papel e vinilo) empeza a notarse na última década do século xx, a da televisión convencional chega dez anos máis tarde coa emerxencia de diversas formas de acceso e consumo do audiovisual mediante descargas (streaming) e novos dispositivos móbiles. O consumo da televisión en liña e en vivo, baseado na programación e no soporte da publicidade como sistema de financiamento, empeza a trocarse por novas formas de acceso e sistema multicanle, sobre todo nas franxas de idades por debaixo dos 35 anos. 
Cadro 4. Trocos no consumo da TV tradicional
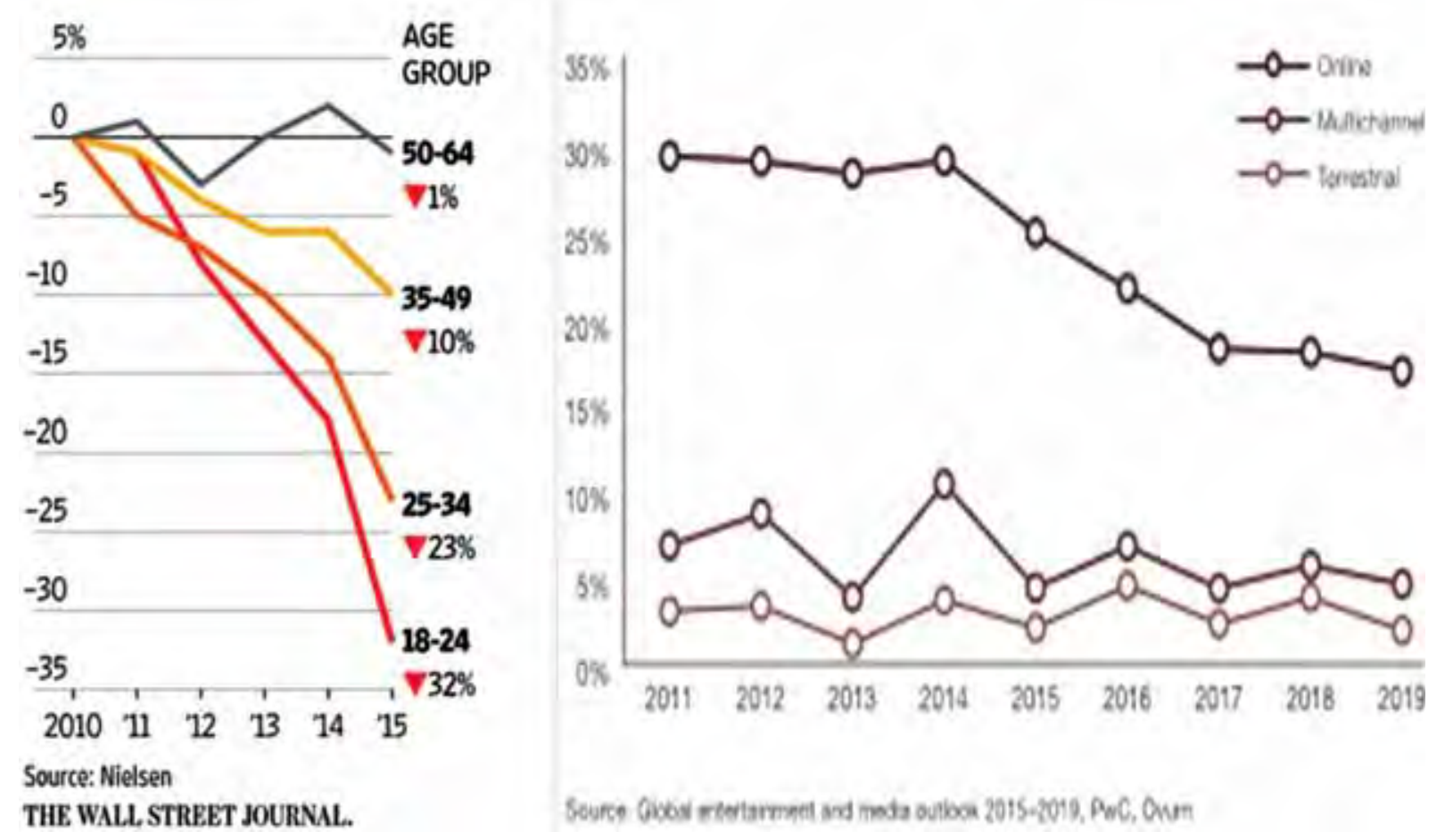

Fontes: De Nielsen-The Wall Street Journal e Global Entertainment and Media Outlook 2015-19 de PWC.

As previsións de ingresos por publicidade na televisión convencional son de clara desaceleración (un 2,8 \% de crecemento na terrestre e un 5,1\% na multicanle) mentres que para o audiovisual en liña o informe de PWC 2015 rexistra un incremento do $20 \%$ a cinco anos vista.

De feito, en Europa, con relación á difusión da TV por ondas hertzianas, que culminou o seu apagamento analóxico en 2014, xa se fala de que entre 2025 e 2030 habería que producir o apagado definitivo da televisión dixital terrestre para liberar as súas radiofrecuencias para a telefonía móbil e Internet (banda 470-694 Mhz). Esta proposta de supresión total da TDT foi levada á Conferencia Mundial de Radiofrecuencias de 2015 e rexeitada polos operadores tradicionais de televisión, que recorreron a informes de Pascual Lamy e de impacto económico negativo por máis de 38500 millóns de euros. 0 tema é dramático para a televisión en aberto e, sobre todo, para a radiotelevisión pública, que, cada vez que se produce un apagamento tecnolóxico, perde máis peso e forza.

A versatilidade dos diversos equipos e redes de acceso está cambiando radicalmente os usos do audiovisual, descargando e elaborando menús personalizados a medida dos distintos gustos e tempos de consumo dispoñibles, sen necesidade de estar pendentes da programación horaria en liña nin sometidos á atención dos anuncios publicitarios. Un estudo de Ericson (2015) revela, baseándose nunha enquisa realizada nos 20 principais mercados mundiais, que os espectadores durante a emisión da publicidade deciden, pola seguinte orde, cambiar de canle para ver outros programas; deixar de prestar atención á pantalla para facer outra cousa; navegar por Internet coa computadora ou co teléfono intelixente; interactuar nos medios sociais; usar un bloqueador de publicidade; buscar servizos sen publicidade; ou gravar contidos para descárgalos logo en streaming noutro momento.

Estas novas formas de uso e consumo cambian o concepto orixinal de televisión (broadcasting) por outro máis amplo de audiovisual e, polo tanto, tamén os seus modelos de negocio. Os servizos audiovisuais a través de Internet ofrecen novas experiencias para os consumidores consonte a súa flexibilidade (consumir o que se quere e cando se quere), contidos exclusivos personalizados e de maior calidade. Este auxe dos servizos de vídeo (over-the-top, 
OTT) está cambiando pouco a pouco as formas da publicidade. As previsións de ingresos de PWC 2015 sobre a publicidade na televisión xeralista, que ata agora era un investimento maioritario, reflicten unha caída do $5 \%$ para os próximos cinco anos, aínda que se manterán arredor do $90 \%$.

Nas enquisas, os consumidores comprenden que a publicidade é un sistema de financiamento necesario para a produción de contidos pero rexeitan a saturación e a intrusión desta (Ericson 2015). Valoran máis favorablemente a inclusión da publicidade ao comezo ou ao final das reproducións -porque a poden saltar- que a intrusión dela no medio dos contidos. Por iso a chamada publicidade nativa de colocación de produto (encaixada dentro dos contidos) e os servizos coma YouTube, Netflix, Amazon ou Hulu están a cobrar grande importancia nos modelos de distribución e negocio do audiovisual. Eses modelos están orientando tamén a publicidade cara ao patrocinio, bartering, márketing data, xeolocalización e personalización dos receptores.

O impacto económico global deses novos operadores dixitais detectouse rechamantemente a mediados de agosto de 2015 nas cotizacións dos principais grupos de medios audiovisuais (Disney, 21st Century Fox, Time Warner ou Viacom) do Index 500 de Standard \& Poor's de Nova York, no que en dous días perderon máis de mil millóns de capitalización -a caída máis forte desde 2008- ao revelarse as baixas nas subscricións da televisión de pago (principalmente da canle ESPN dos grandes acontecementos deportivos) fronte ao ascenso espectacular de Netflix, que xa ten 41 millóns de afiliados en Estados Unidos e unha valoración bolsista de 54000 millóns de dólares, case ao mesmo nivel que a Fox de Rupert Murdoch.

O modelo Netflix está comezando a atacar igualmente as marxes de negocio dos operadores europeos. En Francia xa acada unha cota do $10 \%$ do mercado. Tanto que as empresas tradicionais reaccionan con ofertas semellantes (BBC) e alianzas a distintas bandas (NBC/Universal/Concast buscando a Vox Media e BuzzFed, Facebook creando Live ou Fox Sports xuntándose con YouTube) para non perder a carreira da innovación.

Outra estratexia reactiva é a concentración dos grupos mediáticos. As 50 maiores empresas do mundo neste sector facturan máis de 400000 millóns de dólares, o 66,49 \% dese importe (264 131 millóns) é de Estados Unidos, o 17,2 \% (68 500 millóns) de Europa, o 12,5 \% (49 798 millóns) de Xapón e o 17,2% (15 112 millóns) doutros países. E dos 50 principais grupos audiovisuais presentes en Europa, 27 son de EE.UU. (máis do 50 \%), 6 de Xapón, 4 de Alemaña, 3 do Reino Unido, 2 de Francia, 2 de Italia, 1 de Brasil e outro de México (OBS 2014).

O panorama audiovisual europeo de 2008 a 2012, período do que se dispón de datos comparativos homoxéneos, apuntaba as tendencias que agora se están a revelar, coa excepción de que nese intre aínda non se apreciaba o impacto na televisión de pago tradicional dos novos servizos dixitais, que porén xa despuntaban con altas porcentaxes de crecemento; e como tamén o facía o vídeo baixo demanda. A industria audiovisual europea (incluíndo os videoxogos) reporta arredor de 135000 millóns de euros e 640000 empregos por parte de 122755 empresas. A televisión tradicional xera preto de 75000 millóns de euros; a televisión de pago, 35000 millóns, e o cine, case 7000 millóns.

Cadro 5. Panorama audiovisual europeo

\begin{tabular}{lrrrrrrr} 
Operadores & $\mathbf{2 0 0 8}$ & $\mathbf{2 0 0 9}$ & $\mathbf{2 0 1 0}$ & $\mathbf{2 0 1 1}$ & $\mathbf{2 0 1 2}$ & $\mathbf{2 0 1 2 - 2 0 1 1}$ & $\mathbf{2 0 1 2 - 2 0 0 8}$ \\
\hline \multicolumn{7}{c}{ Relevisión en aberto } \\
\hline RTV públicas & 32370 & 33434 & 33815 & 33687 & 32626 & $-3,1 \%$ & $0,7 \%$ \\
\hline Publicidade TV & 21664 & 20096 & 21139 & 21941 & 21057 & $-4,0$ & $-2,8$ \\
\hline TV temática & 9021 & 9791 & 10859 & 12334 & 12578 & 2,0 & 39,43 \\
\hline Televenda & 2442 & 2423 & 2577 & 2719 & 2800 & 3,0 & 14,66 \\
\hline TV local & 1607 & 1555 & 1573 & 1496 & 1423 & $-4,9$ & $-11,44$ \\
\hline Radio privada & 4167 & 3893 & 4040 & 4168 & 4115 & $-1,3$ & $-1,24$ \\
\hline Total TV & 71270 & 71192 & 74002 & 76345 & 74599 & $-2,3$ & 4,67 \\
\hline
\end{tabular}




\begin{tabular}{|c|c|c|c|c|c|c|c|}
\hline Operadores & 2008 & 2009 & 2010 & 2011 & 2012 & 2012-2011 & 2012-2008 \\
\hline \multicolumn{8}{|c|}{ Ingresos da TV de pago } \\
\hline Cable & 11201 & 11314 & 12050 & 12328 & 12952 & 5,0 & 15,63 \\
\hline Satélite & 13255 & 13298 & 14954 & 15470 & 16219 & 4,8 & 22,36 \\
\hline IPTV & 1395 & 2042 & 2899 & 3343 & 4168 & 24,7 & 198,78 \\
\hline DTT & 598 & 954 & 1439 & 1525 & 1613 & 5,8 & 169,73 \\
\hline Total & 26448 & 27609 & 31342 & 32677 & 34952 & 7,0 & 32,15 \\
\hline \multicolumn{8}{|c|}{ Cine e vídeo } \\
\hline Recadación cine & 5626 & 6087 & 6373 & 6445 & 6570 & 1,9 & 16,77 \\
\hline DVD venda & 7727 & 6729 & 6198 & 5532 & 4913 & $-11,2$ & $-36,41$ \\
\hline DVD alugueiro & 1372 & 1167 & 1037 & 900 & 763 & $-15,2$ & $-44,38$ \\
\hline Blu-ray venda & 234 & 500 & 807 & 982 & 1126 & 14,7 & 381,19 \\
\hline Bluray alugueiro & 16 & 42 & 84 & 116 & 163 & 41,3 & 918 \\
\hline Total vídeo & 9348 & 8438 & 8126 & 7530 & 6966 & $-7,55$ & $-25,48$ \\
\hline \multicolumn{8}{|c|}{ Ingresos do vídeo en liña } \\
\hline VOD TV & 97 & 161 & 298 & 392 & 575 & 46,6 & 482,78 \\
\hline VOD cine & 26,8 & 59,0 & 117,2 & 189,2 & 380,9 & $10,1,3$ & 132,12 \\
\hline VOD total & 124 & 220 & 415 & 582 & 596 & 64,4 & 380,64 \\
\hline Videoxogos & 10848 & 10683 & 11061 & 11150 & 10886 & $-2,4$ & 0,35 \\
\hline Total audiovis. & 123664 & 124230 & 131318 & 134729 & 134929 & 0,1 & 9,10 \\
\hline \multicolumn{8}{|c|}{ Empresas audiovisuais europeas, ingresos e emprego } \\
\hline$\overline{N^{\circ}}$ empr. AV & & 110151 & 122165 & 122755 & & 11,4 & 11,44 \\
\hline Ingresos & & 126639 & 130768 & 131239 & & 0,4 & 3,63 \\
\hline Emprego & & 648053 & 643603 & 639450 & & $-0,6$ & $-1,32$ \\
\hline
\end{tabular}

Fonte: elaboración propia con datos de ingresos en millóns de euros do European Audiovisual Observatory (OBS 2014). No apartado de empresas e emprego, os datos refírense ás comparacións dos anos 2011-2010 e 2009, respectivamente.

A taxa de crecemento da televisión de pago, pola saturación de ofertas e a entrada dos novos operadores, tamén está trastornándose e desacelerándose, sobre todo en América do Norte e Europa Occidental, baixou dun 5,3\% de incremento entre 2010 e 2014 a un 3,4 \% de 2015 a 2019, segundo o informe de PWC. A batalla está agora na conformación das ofertas, prezos e economías de escala coas que se teñen que enfrontar os vellos e novos operadores. As microofertas multiflexibles por 9 dólares ao mes dos novos operadores (Netflix ou Amazon) rompen os prezos e as programacións das plataformas tradicionais de pago.

A flexibilidade desas novas plataformas de distribución de contidos a través de Internet -con capacidade e custos de estrutura moitísimo máis baixos que as redes terrestres, de cable ou satélite- permiten amplas e variadas ofertas de contidos que impulsan a industria cinematográfica e tamén oportunidades para os creadores independentes. Non obstante, esas plataformas están empezando, pola súa vez, a introducirse na produción de series e películas para nutrir os seus catálogos.

Esa demanda xunto cos novos dispositivos de acceso móbil (tabletas e teléfonos) e cos mercados emerxentes de Asia e América Latina fortalecen as previsións de recuperación da industria cinematográfica, que se estima que medrará arredor do 4,1 \% anual ata 2019. O mesmo ocorre coa produción de videoxogos, nos que tamén se está a dar o troco dos modelos analóxicos aos dixitais, ao xogo social, á distribución a través da nube e á irrupción da realidade virtual tanto para os espazos de entretemento como para os de información xornalística e formación educativa. 
A análise da evolución dos ingresos e resultados dos grandes grupos audiovisuais privados europeos confirma de igual maneira as tendencias que se veñen comentando. Aínda que cada un deles é o resultado dunha estrutura económico-financeira diferente, a partir de 2011-12 pódese apreciar unha clara contención nos ingresos e resultados froito da apertura do punto de inflexión online do negocio tradicional do audiovisual.

Cadro 6. Resultados dos grandes grupos audiovisuais da UE

\begin{tabular}{|c|c|c|c|c|c|c|c|c|}
\hline Grupos e país matriz & & 2008 & 2009 & 2010 & 2011 & 2012 & 2013 & 2014 \\
\hline \multirow{2}{*}{$\overline{\text { RTL Luxemburgo }}$} & Ingresos & 5774 & 5410 & 5591 & 5765 & 5998 & 5889 & 5808 \\
\hline & Resultados & 296 & 298 & 730 & 795 & 690 & 948 & 714 \\
\hline \multirow[t]{2}{*}{ BSKyBReino Unido } & Ingresos & 6250 & 7293 & 7772 & 8980 & 9244 & 9846 & 10386 \\
\hline & Resultados & -173 & 352 & 1185 & 1102 & 1232 & 1331 & 1174 \\
\hline \multirow[t]{2}{*}{ Canal + Francia } & Ingresos & 1813 & 1775 & 1787 & 1846 & 1878 & 1882 & 1830 \\
\hline & Resultados & 56 & 57 & 59 & 60 & 62 & 63 & 63 \\
\hline \multirow[t]{2}{*}{ TF1Francia } & Ingresos & 2594 & 2364 & 2622 & 2619 & 2215 & 2085 & 2091 \\
\hline & Resultados & 176 & 101 & 313 & 282 & 153 & 146 & 116 \\
\hline \multirow[t]{2}{*}{ PRISAEspaña } & Ingresos & 994 & 902 & 977 & 1138 & 1333 & 1546 & \\
\hline & Resultados & -269 & -676 & -407 & -277 & -195 & -133 & \\
\hline \multirow[t]{2}{*}{ Modern TimesSuecia } & Ingresos & 1385 & 1486 & 1378 & 1417 & 1403 & 1486 & \\
\hline & Resultados & 308 & 308 & 372 & -135 & 168 & 123 & \\
\hline \multirow[t]{2}{*}{ Prosieben SatAlemaña } & Ingresos & 3054 & 2760 & 2601 & 2199 & 2356 & 2605 & 2875 \\
\hline & Resultados & 125 & 150 & 346 & 312 & 295 & 637 & 312 \\
\hline \multirow[t]{2}{*}{ MediasetItalia } & Ingresos & 3271 & 3228 & 3438 & 3241 & 2835 & 2588 & \\
\hline & Resultados & 272 & 272 & 352 & 225 & -287 & 8,9 & \\
\hline \multirow[t]{2}{*}{ CEMEBermudas } & Ingresos & 905 & 605 & 654 & 767 & 626 & 562 & 604 \\
\hline & Resultados & -226 & -95 & 85 & -159 & -484 & -249 & -205 \\
\hline \multirow[t]{2}{*}{ TVN-ITIPolonia } & Ingresos & 393 & 369 & 392 & 394 & 337 & 327 & 323 \\
\hline & Resultados & 95 & 98 & 65 & 266 & 7,1 & -40 & 26 \\
\hline
\end{tabular}

Fonte: elaboración propia con datos en millóns de euros, a partir dos resultados publicados polas respectivas empresas.

\section{MODELOS DE NEGOCIO E ESTRATEXIAS}

A industria mediática actual está experimentando unha acelerada transición dos modelos tradicionais físicos e analóxicos aos da economía dixital e intanxible. Pero o gran reto e desafío é como xestionar esa economía dixital para protexer dereitos básicos individuais e equilibrar a sustentabilidade de moitas organizacións imprescindibles para o mantemento do pluralismo e a diversidade.

A innovación disruptiva que introduciu Internet e a dixitalización abriron as comportas de novos modelos de negocio, de espazos desregulamentados, desprotección da propiedade intelectual e a privacidade, de novas economías da colaboración, da gratuidade, do troco e da pescuda do data márketing a partir das pegadas dixitais producidas pola navegación. Pero o paradoxo dalgunhas desas economías é a sobreexplotación da atención, a experiencia, as interacións, o procomún dos prosumer e a privacidade das individualidades porque, cando non se paga polo produto, o usuario é o produto. 
Os modelos de negocio representan as bases mediante as cales unha empresa ou organización crea, proporciona e capta valor para a súa clientela, socios, empregados, asociados e para a sociedade en xeral a partir dos seguintes elementos: mercados e clientes, propostas de valor dos produtos ou servizos, canles de distribución e comunicación, sistemas de relación cos clientes, fontes de ingresos e prezos, recursos e actividades clave, asociacións estratéxicas e estrutura e tipos de custos. Os principais modelos de negocio das industrias da comunicación, segundo os seus sistemas de transacción (Celaya 2014), pódense agrupar nas seguintes categorías:

1. De propiedade, financiamento e xestión pública (radiotelevisións): canon, subvención, convenios, préstamos financiados, bonificacións e/ou exencións fiscais.

2. De pago do produto: por unidade, paquete, subscrición e alugueiro.

3. De publicidade: acceso aberto ou libre, patrocinio, bartering, merchandising e product placement (colocación de produto/publicidade nativa).

4. De pago do servizo dixital audiovisual: triplo e múltiple play, pago por visión (PPV), por descarga, por paquete, subscrición e alugueiro de acceso a streaming.

5. De paywall de prensa: micropagos, paquete (blendle), muro fechado de pago total, freemium-premium; pago mediado; e membresía ou club.

6. De agregadores de multiservizos e plataformas de fidelización de clientes (ofrecer contidos gratis para gañar clientes para servizos de pago).

7. De márketing data: comercialización de datos dixitais de afiliación rexistrados polos usuarios nas plataformas e redes sociais.

8. De recomendación (economía do click) e reputación dixital de servizos.

9. De comunidades de filantropía, crowfunding e mecenado.

10. Doutras formas híbridas: P2P-MOOC'S, crowdsourcing ou gamificación.

Pero a converxencia dixital non só revoluciona os modos de consumo e modelos de negocio tradicionais, senón tamén as estruturas e formas de organización da creación, produción e xestión das empresas, que necesitan situar os consumidores moito máis no centro do seu corazón estratéxico para recuperar a súa confianza con rapidez, axilidade e innovación. Un reto enorme para moitas organizacións tradicionais e, sobre todo, en Europa para as da radiotelevisión pública -que abordaremos a continuación- que aínda permanecen ancoradas nas vellas estruturas burocratizadas e politizadas do século xx.

As principais barreiras, porén, coas que as empresas chocan para enfrontar o cambio -segundo o informe de Global Digital Media (WNMN 2014), realizado a partir dunha enquisa a 340 expertos en xestión de medios de comunicaciónson as seguintes: falta de talento nas áreas emerxentes das organizacións e na alta dirección delas, necesidades de capital e crédito para novos investimentos, conflitos de prioridades nas axendas internas (é dicir, como abandonar 0 pasado e presente febles, pero coñecidos, polo incerto futuro descoñecido), baixo nivel de investigación e innovación rigorosas, culturas obsoletas e necesidades de reestruturación, adaptación de novas métricas e ferramentas de xestión.

Nas prioridades que marcan os directivos da mostra mundial de medios de comunicación sobresaen as necesidades de reestruturación das organizacións, investimentos en tecnoloxía, desenvolver novos produtos, impulsar a creatividade e a innovación, racionalizar os sistemas e procesos produtivos, expansión nos mercados internos e externos, profundamento en sectores verticais, externalizar procesos de pouco valor engadido e cooperación para a sindicación de contidos. A necesidade convértese na matriz da innovación, tanto no ámbito organizacional coma no da creatividade de novos contidos e formatos, que converxen cara ao vídeo móbil, consumos non lineais e baixo demanda, busca de novas métricas e sistemas de monetización dos novos modelos de negocio. 


\section{O FUTURO DA RADIOTELEVISIÓN PÚBLICA}

O debate aberto no verán de 2015 sobre a próxima Carta Real da BBC (o documento estratéxico da corporación británica para 2017-2027) marca as tendencias de futuro da radiotelevisión pública en Europa. O Goberno conservador de David Cameron presentou diante do Parlamento do Reino Unido a BBC Charter Review Public Consultation (16 july-8 october 2015), que é a primeira consulta pública para elaborar a Carta Real da corporación de radiodifusión británica que deberá estar vixente o día 1 de xaneiro de 2017 e que marcará a estratexia para os dez anos seguintes, nos que precisamente esa corporación celebrará o seu centenario (2022).

Sen considerar que o modelo xeral europeo de radiotelevisión pública é equiparable á corporación británica, o seu debate e definición serven de referencia para outros países. A clasificación dos distintos modelos europeos de radiotelevisión pública pódese establecer sobre cinco grandes criterios: a) segundo o modelo de sistemas mediáticos comparados (Hallin / Mancini 2008); b) segundo o sistema de financiamento; c) segundo a súa configuración da organización institucional e territorial; d) segundo o seu sistema de gobernanza e control; e) segundo a súa penetración e audiencias fronte á competencia privada. A partir deses cinco grandes criterios pódense formular dez modelos diferenciais:

1. Modelos de sistemas mediáticos comparados: a) liberal (BBC do Reino Unido e RTE de Irlanda); b) corporativo-democrático (países do norte: Finlandia, Suecia, Alemaña, Noruega); c) pluralista partidista (países mediterráneos: Francia, Italia, España, Grecia, Portugal).

2. Modelos financiados maioritariamente a través de taxas impositivas: a) de canon directo sobre fogares (BBC, RTE, RTBF, VRT, ERT, ORF, ARD, ZDF, RAI, France TV); b) canon directo persoal (que se tributa a través da declaración do imposto da renda das persoas físicas, YLE de Finlandia); e c) canon indirecto (a través de operadores de telecomunicacións e televisión comerciais, RTVE e France TV).

3. Modelos de financiamento mixto de publicidade, canon e/ou subvención: radiotelevisións autonómicas de España, Alemaña, Bélxica, Países Baixos, Portugal, Italia e Irlanda.

4. Modelo único de diversidade institucional independente (países nórdicos e Suíza) mediante organización federal de canles rexionais integradas.

5. Modelo estatal confederado (España e Alemaña) a través dunha organización estatal (RTVE e ZDF) e outra de corporacións independentes asociadas (FORTA e ARD).

6. Modelo de diversidade rexional nacional (Bélxica) mediante tres organizacións independentes (RTBF, VRT e BRF) para as comunidades francesa, flamenca e alemá, respectivamente.

7. Modelo estatal rexionalizado (Francia e Italia) con ventás e desconexións, tamén compartido por RTVE de España.

8. Modelo estatal de cooperación institucional e local (Reino Unido, Holanda e Irlanda). No caso do Reino Unido a través de 15 ventás rexionais da BBC para Inglaterra, Gales, Escocia e Irlanda de Norte, compartido coas canles locais das redes de ITV, STV de Escocia e UTV do Ulster.

9. Segundo os sistemas de gobernanza: a) órganos de control interno e externo independente e converxente (Reino Unido, Irlanda, Italia, Portugal, Bélxica, Austria, Finlandia e España); b) de control interno e externo audiovisual independente (Francia, Alemaña, Cataluña e Andalucía).

10. Segundo a súa penetración e audiencias respecto ás televisións privadas: a) de liderado e impacto maioritario (BBC e países nórdicos); b) de perda de influencia e menores audiencias (países mediterráneos).

A pesar desa tipoloxía de singularidades, os principais problemas da radiotelevisión pública son comúns e pasan pola súa perspectiva de futuro diante do novo escenario dixital no que o sistema dual tradicional europeo (público-privado) é moito máis aberto e complexo que hai dez anos. Eses principais problemas pódense concretar 
en cinco aspectos de regulación, financiamento, gobernanza, rendición de contas e reconversión e innovación. Por iso, o documento DCMS Green Paper on Charter Renewal da BBC, ao que voltaremos máis adiante, ten tanta importancia como rumbo estratéxico de futuro. Con eses cinco problemas estruturais en mente e o documento da Secretaría de Cultura (DCMS) do Reino Unido á man poñemos por diante neste documento dez ideas sobre o futuro da radiotelevisión pública europea.

1.- As políticas de regulación e comunicación, tanto da Unión Europea como dos seus Estados, teñen que ser menos retóricas e máis realistas ou concretas sobre o futuro do servizo público audiovisual se queren autorrecoñecer e proxectar a súa diversidade de sociedades no contexto da sociedade global.

Non só o futuro, senón tamén o presente, da radiotelevisión é dixital e audiovisual. A radiotelevisión do século XXI é un servizo audiovisual que cada vez converxe máis con Internet. Chama moito a atención que o documento BBC Paper on Charter Renewal para a súa nova Carta Real 2017-2027 non mencione a televisión dixital terrestre, que en 2022 pasará da banda 470-862 MHz á de 470-694 MHz. Pero desta última tamén pode ser excluída pola presión e requirimento de maior espazo radioeléctrico dos operadores de telefonía móbil. Esta posibilidade cambiaría radicalmente os modelos de difusión e negocio do audiovisual, que pasarían integramente a Internet. Se isto vai adiante -o tema só foi temporalmente descartado ata 2030 na Conferencia Mundial de Radiocomunicacións-, á radiotelevisión tradicional, masiva e aberta, que hoxe coñecemos -principalmente á de propiedade pública- quédanlle apenas 15 anos de vida.

Por iso, vale a pena a reflexión e a chamada de atención sobre o futuro dos servizos audiovisuais públicos en Europa, tras dúas décadas de políticas brandas e desregulatorias. O modelo tradicional de eclecticismo dual público-privado non vale para a próxima década porque Europa, os seus estados e as comunidades nacionais con competencias transferidas nesa materia terán que decantarse por atopar un novo estatuto de reestruturación e promoción do audiovisual público ou dar vía libre ao seu desmantelamento final. Se a opción é a favor da salvagarda, a tarefa urxente é impulsar e asentar a estratexia dixital.

O documento oficial da consulta pública do Goberno británico sobre a reforma da Carta Real da BBC aborda as mesmas cinco cuestións formuladas de carácter xeral ao inicio desta epígrafe: misión e propósito da BBC, servizos que debe prestar, modo de financiamento, gobernanza e transparencia. A propia presentación do propio informe británico acendeu a polémica, por estar a cargo do novo secretario de Cultura, John Whittingadle, un dos «falcóns» do partido conservador e crítico coa BBC pola súa chamada «cultura da progresía». A propia prensa británica xa se posicionou claramente en dous bandos, un deles crítico -The Times, The Daily Telegraph, Daily Mail- e claramente a favor de recortarlle o voo á corporación pública británica, e outro (The Guardian e Daily Mirror) máis condescendente. A nivel de partidos, os conservadores, que gobernan, están por unha reforma con redimensionamento da corporación; e os laboristas, co novo líder Jeremy Corbyn á fronte, a favor da potenciación para compensar a falla de apoios que teñen da prensa privada. A este respecto, tras o referendo do Brexit e o debate sobre o liderado no Partido Laborista, a BBC foi acusada de tratamento parcial en contra de Corbyn por varios académicos e investigadores, entre os que destacan Annabelle Sreberny, Graham Murdock, David Hesmondhalgh, Greg Philo, David Miller, Bev Skeggs e Martin Moore. Ese desequilibrio foi atribuído á autocensura interna por temor ao último tramo de negociación da Carta Real co Goberno conservador.

A proposta de reforma do Goberno británico para a BBC dos próximos dez anos somete a reflexión o ata agora inamovible principio da universalidade do servizo público por algo máis concreto e específico, así como a súa escala e alcance. Malia recoñecer a importancia nacional e global da BBC (chega ao 75 \% dos británicos cada semana e a 300 millóns de persoas en todo o mundo), consideran os tories que o servizo público de ningún modo pode socavar os intereses dos operadores audiovisuais privados. Reclámanlle á corporación máis transparencia, rendición de contas e políticas de control dos escándalos coma os ocorridos en 2012 (casos de pedofilia do ex-presentador Jimmy Savile e das acusacións non verificadas contra o Lord Alistair McAlpine). 
Para a súa gobernanza, o Executivo conservador propuxo a supresión do BBC Trust (creado en 2010 e que representa os intereses dos abonados) e, tamén, tres alternativas: un consello de administración unitario de xestión e control, un órgano interno de control independente ou unha entidade externa de supervisión (o actual regulador converxente, OFCOM).

E para o financiamento da BBC, o Goberno suxeriu tres alternativas: un canon reformado para fogares e todos os dispositivos de radiotelevisión (ata agora só se pagaba polo televisor e non pola recepción a través de Internet, por exemplo na canle iPlayer), un sistema híbrido (taxa e publicidade ou subvención) e, a medio prazo, un sistema de subscrición, coma o da televisión privada. Como se pode apreciar, a reforma da Carta Real abre as portas de par en par da BBC ao futuro de Internet.

2. - Establecemento dunha nova estratexia para o audiovisual conectado e multiplataforma. Diante dun contexto globalizado de sistemas multiplataforma e de intermediarios dixitais globais de agregación de contidos, seguen sendo necesarios os operadores estatais e de proximidade. A UER e os grandes operadores públicos (BBC, ZDF, ARD, FT) así o ven e por iso buscan alianzas para non perder oportunidades de competencia a nivel dixital e global. A televisión do presente e do futuro inmediato é unha tableta polivalente que conecta múltiples canles e metaservizos dixitais de comunicación.

3. - O servizo público debe recuperar terreo a través dos medios sociais dixitais para fortalecer a democracia porque a esfera pública é unha interface que conecta cultura, economía e política na sociedade actual (Fuchs 2014). Esta idea require máis vontade e firmeza das políticas europeas (non só da revisión da Directiva 2010/13UE de servizos audiovisuais e da Axenda Dixital Europea) a través dunha nova estratexia global para a comunicación audiovisual por Internet.

No caso de España e das súas comunidades autónomas, é tamén necesaria de novo a reforma da Lei xeral estatal do audiovisual 7/2010 e a Lei 9/2011 dos medios audiovisuais públicos de Galicia, parcialmente inaplicada cinco anos despois da súa aprobación. 0 marco regulatorio do audiovisual español -intervido pola politización partidista de cada un dos gobernos do momento- segue estando obsoleto e indo moito por detrás dos cambios que se producen no sector.

4.- As malas prácticas de gobernanza deben ser corrixidas mediante modelos expertos, transparentes e avaliados, de regulación, autorregulación e corregulación. Os órganos de regulación e gobernanza dos medios audiovisuais públicos seguen sendo patrimonializados por partidos políticos, sindicatos e asesores/as de comunicación a cambio de prebendas e formas indirectas non transparentes de autofinanciamento dos e das representantes desas institucións.

Fronte a ese modelo de meritocracia política, debería desenvolverse unha alternativa de meritocracia técnica experta independente, transparente e sometida a rendición pública de contas. A regulación da gobernanza institucional debería combinarse con sistemas máis esixentes de autorregulación (rendición de contas, probas de valor público, informes de Responsabilidade Social Corporativa) e de corregulación diante de consellos audiovisuais sectoriais ou converxentes.

5.- As radiotelevisións públicas deben evolucionar da audimetría comercial a outros novos modelos de indicadores de servizo público converxente. Se o seu modelo de negocio non é ou é cada vez menos a comercialización publicitaria mediante a economía da atención, a medición cuantitativa de audiencias xa non se corresponde coa súa propia identidade.

Non se trata só de evolucionar cara a unha nova medición de audiencias sociais senón tamén de buscar outros novos sistemas cualitativos e experimentais de relación cos usuarios dos servizos audiovisuais, na liña da alfabetización mediática e das alternativas de empoderamento a través das web converxentes (método Damian, por exemplo) para aproveitar a conversación social para a transparencia, autocontrol e recuperación da credibilidade e impacto dos servizos audiovisuais públicos. A deflación dos indicadores tradicionais de audiencia das radiotelevisións públicas aconsella, cando menos, unha seria reflexión sobre a busca de alternativas a esa perda de penetración. 
Cadro 7. Evolución das audiencias de TV en España, 1992-2015

19921993199419951996199719981999200020012002200320042005200620072008200920102011201220132014 *2015

\begin{tabular}{|c|c|c|c|c|c|c|c|c|c|c|c|c|c|c|c|c|c|c|c|c|c|c|c|}
\hline .al & 325 & 298 & 27,6 & 627,6 & 26,9 & 25,2 & 25,6 & 24,9 & 24,5 & 24,8 & 24,7 & 23,4 & 21,4 & 19,6 & $18,3 \quad 17,2$ & 16,9 & 16,4 & 16 & 14,5 & 12,21 & 10,2 & 10 & 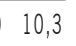 \\
\hline La2 & 8 & 9,5 & 9,8 & 99,2 & 9,1 & 8,9 & 8,8 & 8,1 & 7,9 & 7,8 & 7,7 & 7,2 & 6,8 & 5,8 & $\begin{array}{ll}4,8 \quad 4,6 \\
\end{array}$ & 4,5 & 3,8 & 3,1 & 2,6 & 2,5 & 2,4 & 2,8 & 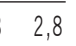 \\
\hline AN & 0 & 0 & 0 & 0 & 0 & 0 & 0 & 0 & 0 & 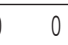 & 0 & 0 & 0 & 0 & $0,1 \quad 0,2$ & 0,6 & 1,4 & 3,2 & 3,2 & 2,5 & 2,4 & 2,3 & $?$ \\
\hline & 0 & 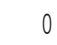 & 0 & 0 & 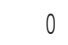 & 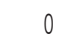 & 0 & 0 & 0 & 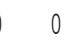 & 0 & 0 & 0 & 0 & $0 \quad 0,1$ & 0,2 & 0,4 & 0,7 & 0,9 & 0,9 & 0,8 & 0,8 & 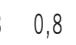 \\
\hline LED & 0 & 0 & 0 & 0 & 0 & 0 & 0 & 0 & 0 & 0 & 0 & 0 & 0 & 0,1 & $0,1 \quad 0,3$ & 0,4 & 0,6 & 1,1 & 1 & 0,8 & 0,9 & 0,9 & 0,7 \\
\hline UPC & 3 & 39,3 & 37,4 & 36,7 & 36 & 34,1 & 34,4 & 33 & 32,4 & 32,6 & 32,4 & 30,7 & 28,3 & 25,4 & $23,3 \quad 22,4$ & 22,6 & 22,7 & 24,1 & 22,3 & 18,91 & 16,7 & 16,7 & 16,7 \\
\hline 2 & 20,7 & 21,4 & 19 & 918,5 & 20,2 & 21,7 & 20,4 & 21 & 22,3 & 21,1 & 20,3 & 21,4 & 22,1 & 22,3 & $21,2 \quad 20,3$ & 18,1 & 15,1 & 14,6 & 14,2 & 13,91 & 13,5 & 14,5 & 14,8 \\
\hline ET & 0 & 0 & 0 & 0 & 0 & 0 & 0 & 0 & 0 & 0 & 0 & 0 & 0 & 0 & 0 & 0,1 & 0,6 & 1,4 & 1,5 & 1,4 & 1,2 & 0,3 & \\
\hline F.T5 & 0 & 0 & 0 & 0 & 0 & 0 & 0 & 0 & 0 & 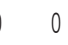 & 0 & 0 & 0 & 0 & 0 & 0,2 & 0,5 & 1,5 & 2,6 & 2,9 & 2,9 & 3,5 & 3, \\
\hline $30 I N G$ & 0 & & 0 & 0 & 0 & 0 & 0 & 0 & 0 & 0 & 0 & 0 & 0 & 0 & 0 & 0 & 0 & 0,2 & 1,1 & 1,7 & 1,7 & 1,7 & 1 \\
\hline TRO & 0 & 0 & 0 & 0 & 0 & 0 & 0 & 0 & 0 & 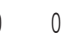 & 0 & 0 & 0 & 0,8 & $6,4 \quad 7,7$ & 8,6 & 8,2 & 7 & 6,1 & 6 & 6 & 6,7 & 7 \\
\hline VINITY & 0 & 0 & 0 & 0 & 0 & 0 & 0 & 0 & 0 & 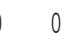 & 0 & 0 & 0 & 0 & 0 & 0 & 0 & 0 & 0,7 & 1,4 & 1,7 & 2,1 & 2 \\
\hline ERG & 0 & 0 & 0 & 0 & 0 & 0 & 0 & 0 & 0 & 0 & 0 & 0 & 0 & 0 & 0 & 0 & 0 & 0 & 0 & 0,9 & 1,2 & 1,5 & ; \\
\hline DIAS & 7 & 21,4 & 19 & 18,5 & 20,2 & 21,7 & 20,4 & 21 & 22,3 & 21,1 & 20,3 & 21,4 & 22,1 & 23,1 & $27,6 \quad 28$ & 27 & 24,4 & 24,7 & 26,2 & 28,12 & 28,3 & 30,4 & 31,4 \\
\hline 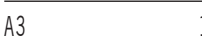 & 14,7 & 21,1 & 25,7 & 26 & 25 & 22,9 & 22,8 & 22,8 & 21,6 & 20,5 & 20,3 & 19,5 & 20,8 & 21,3 & $19,4 \quad 17,4$ & 16 & 14,7 & 11,7 & 11,5 & 12,51 & 13,4 & 13,6 & 13 \\
\hline VA & 0 & 0 & 0 & 0 & 0 & 0 & 0 & 0 & 0 & 0 & 0 & 0 & 0 & 0 & $0,1 \quad 0,1$ & 0,4 & 0,7 & 1,5 & 1,5 & 1,6 & 2,1 & 2,5 & 2 \\
\hline IEOX & 0 & 0 & 0 & 0 & 0 & 0 & 0 & 0 & 0 & 0 & 0 & 0 & 0 & 0 & $0,1 \quad 0,2$ & 0,6 & 1,2 & 2,2 & 2,7 & 2,6 & 2,3 & 2,6 & 2, \\
\hline $\mathrm{RO}^{*}$ & 0 & 0 & 0 & 0 & 0 & 0 & 0 & 0 & 0 & 0 & 0 & 0 & 0 & 0 & 0 & 0 & 0 & 0,4 & 1,4 & 1,6 & 1,7 & 0,6 & \\
\hline SEXT & 0 & 0 & 0 & 0 & 0 & 0 & 0 & 0 & 0 & 0 & 0 & 0 & 0 & 0 & 0 & 0 & 0 & 0,1 & 0,6 & 0,2 & 0 & 0 & 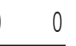 \\
\hline SEX & 0 & 0 & 0 & 0 & 0 & 0 & 0 & 0 & 0 & 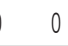 & 0 & 0 & 0 & 0 & 0 & 0 & 0 & 0,1 & 1,4 & 1,6 & 1,6 & 0,6 & \\
\hline SEXT & 0 & 0 & 0 & 0 & 0 & 0 & 0 & 0 & 0 & 0 & 0 & 0 & 0 & 0 & 1,8 & 5,5 & 6,8 & 6,6 & 5,7 & 4,9 & 6 & 7,2 & 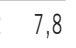 \\
\hline RESMEDIA & 4,7 & 21,1 & & 726 & 26 & 22,9 & 22,8 & 22,8 & 21,6 & 20,5 & 20,3 & 19,5 & 20,8 & 21,3 & $21,3 \quad 21,8$ & 22,5 & 23,4 & 22,6 & 24,7 & 24,92 & 27,1 & 27,1 & 26,7 \\
\hline NEY & 0 & 0 & 0 & 0 & 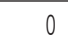 & 0 & 0 & 0 & 0 & 0,1 & 0,1 & 0,1 & 0,1 & 0,1 & $0,2 \quad 0,1$ & 0,4 & 1,4 & 2,1 & 1,7 & 1,6 & 1,5 & 1,5 & 1, \\
\hline NTEREC & 0 & 0 & 0 & 0 & 0 & 0 & 0 & 0 & 0 & 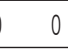 & 0 & 0 & 0 & 0 & 0 & 0,1 & 0,5 & 1,1 & 1,4 & 1,2 & 0,9 & 0,1 & \\
\hline$V * *$ & 0 & 0 & 0 & 0 & 0 & 0 & 0 & 0 & 0 & 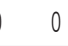 & 0 & 0 & 0 & 0 & 0 & 0 & 0 & 0,1 & 0,5 & 0,7 & 0,6 & 0,1 & \\
\hline PARAMO & $\begin{array}{cl}\text { EL } & 0 \\
\end{array}$ & 0 & 0 & 0 & 0 & 0 & 0 & 0 & 0 & 0 & 0 & 0 & 0 & 0 & 0 & 0 & 0 & 0 & 0 & 0,8 & 1,4 & 1,9 & 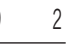 \\
\hline RUPO & 0 & 0 & 0 & 0 & 0 & 0 & 0 & 0 & 0 & 0,1 & 0,1 & 0,1 & 0,1 & 0,1 & $0,2 \quad 0,1$ & 0,5 & 1,9 & 3,3 & 3,6 & 4,4 & 4,4 & 3,5 & 3,4 \\
\hline V & 0 & 0 & 0 & 0 & 0 & 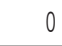 & 0 & 0 & 0 & 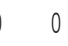 & 0 & 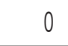 & 0 & 0 & 0 & 0 & 0 & 0 & 0,4 & 1 & 1,3 & 1,6 & 1, \\
\hline MARCA TV & 0 & 0 & 0 & 0 & 0 & 0 & 0 & 0 & 0 & 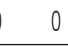 & 0 & 0 & 0 & 0 & 0 & 0 & 0 & 0,2 & 0,8 & 1 & 0,6 & 0 & ) \\
\hline ISCOV & 0 & 0 & 0 & 0 & 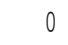 & 0 & 0 & 0 & 0 & 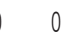 & 0 & 0 & 0 & 0 & 0 & 0 & 0 & 0 & 0 & 1,2 & 1,6 & 2,1 & 2, \\
\hline GRUPO UNID. ED. & 0 & 0 & 0 & 0 & 0 & 0 & 0 & 0 & 0 & 0 & 0 & 0 & 0 & 0 & 0 & 0 & 0 & 0,2 & 1,2 & 3,2 & 3,5 & 3,6 & 3 \\
\hline$\varepsilon$ & 8 & & 1 & 81,2 & 81,2 & 78,7 & 77,6 & 76,8 & 76,3 & 74,3 & 73,1 & 71,7 & 71,3 & 69,9 & $72,4 \quad 72,3$ & 72,6 & 72,4 & 74,9 & 78 & 79,5 & 80 & 81,3 & 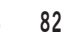 \\
\hline
\end{tabular}

O contraste da evolución dos resultados de audiencia da televisión pública e privada en España é rechamante no transcurso dos últimos 20 anos. As televisión públicas acaparaban en 1992 o $65 \%$ da audiencia fronte ao $30 \%$ das privadas, pero 23 anos despois as tornas vólvense ao revés. As autonómicas resisten mellor arredor do $10 \%$ as canles das comunidades históricas, entre elas a de Galicia. 
Cadro 8. Audiencias das TV autonómicas, 1992-2015

19921993199419951996199719981999200020012002200320042005200620072008200920102011201220132014 *2015

\begin{tabular}{lllllllllllllllllllllllllll}
\hline TVG & 17 & 15,5 & 14,6 & 15,4 & 16,5 & 18,5 & 18,1 & 18,6 & 19 & 18,3 & 16,7 & 18 & 17,4 & 17,2 & 14,4 & 14,1 & 15,5 & 14,3 & 12,3 & 12,3 & 11,5 & 10,9 & 10 & 9,8
\end{tabular}

\begin{tabular}{llllllllllllllllllllllllll}
\hline TVG2 & 0 & 0 & 0 & 0 & 0 & 0 & 0 & 0 & 0 & 0 & 0 & 0 & 0 & 0 & 0 & 0 & 0 & 0,1 & 0,8 & 0,9 & 0,9 & 0,9 & 0,8 & 0,7
\end{tabular}

\begin{tabular}{lllllllllllllllllllllllll}
\hline GRUPO CRTVG & 17 & 15,5 & 14,6 & 15,4 & 16,5 & 18,5 & 18,1 & 18,6 & 19 & 18,3 & 16,7 & 18 & 17,4 & 17,2 & 14,4 & 14,1 & 15,5 & 14,4 & 13,2 & 13,2 & 12,4 & 11,8 & 10,9 & 10,4
\end{tabular} \begin{tabular}{lllllllllllllllllllllllllll}
\hline CSUR HD & 0 & 0 & 0 & 0 & 0 & 0 & 0 & 0 & 0 & 0 & 0 & 0 & 0 & 0 & 0 & 0 & 0 & 0 & 0 & 0 & 0 & 0 & 0 & 0,3
\end{tabular} \begin{tabular}{llllllllllllllllllllllllll}
\hline C. SUR & 20,1 & 18,9 & 16,6 & 16,4 & 16,3 & 19,5 & 19,5 & 18,8 & 17,8 & 17,3 & 17,2 & 17,9 & 19,2 & 20,2 & 17,5 & 16,9 & 16,8 & 15,6 & 12,7 & 10,7 & 10,1 & 9,9 & 9,5 & 9,1
\end{tabular} \begin{tabular}{lllllllllllllllllllllllllll}
\hline $\operatorname{CS2}^{* *}$ & 0 & 0 & 0 & 0 & 0 & 0 & 0,5 & 2,1 & 3,5 & 4,2 & 4,6 & 5,2 & 5,5 & 5,5 & 4,2 & 3,9 & 4,1 & 3,2 & 1,9 & 1,5 & 1 & 0 & 0 & 0
\end{tabular} \begin{tabular}{lllllllllllllllllllllllll}
\hline GRUPO C. SUR & 20,1 & 18,9 & 16,6 & 16,4 & 16,3 & 19,5 & 20 & 20,9 & 21,3 & 21,5 & 21,8 & 23,1 & 24,7 & 25,7 & 21,7 & 20,8 & 20,9 & 18,8 & 14,6 & 12,2 & 11,1 & 9,9 & 9,5 & 9,4
\end{tabular} \begin{tabular}{llllllllllllllllllllllllllll}
\hline TV3 & 21,5 & 19,2 & 22,5 & 21,4 & 19,1 & 22 & 23,6 & 22,1 & 21,2 & 21,8 & 21,4 & 21,1 & 19,9 & 19,6 & 18,2 & 16,6 & 14,6 & 14,5 & 14,8 & 14,1 & 14,3 & 13,5 & 12,6 & 12,6
\end{tabular} \begin{tabular}{llllllllllllllllllllllllll}
\hline $33^{* *}$ & 6,1 & 5,6 & 5,2 & 4,3 & 6,9 & 7,1 & 5,7 & 5,2 & 5,1 & 6,1 & 7 & 6,8 & 6,2 & 5,3 & 4,3 & 3,4 & 2,9 & 1,9 & 1,6 & 1,6 & 1,1 & 0 & 0 & 0
\end{tabular} \begin{tabular}{lllllllllllllllllllllllll}
\hline SUPER 3/33 & 0 & 0 & 0 & 0 & 0 & 0 & 0 & 0 & 0 & 0 & 0 & 0 & 0 & 0 & 0,3 & 0,5 & 0,5 & 0,7 & 1,1 & 1,1 & 1,3 & 1,2 & 1,3 & 1,4
\end{tabular} \begin{tabular}{llllllllllllllllllllllllll}
\hline SUPER 3** & 0 & 0 & 0 & 0 & 0 & 0 & 0 & 0 & 0 & 0 & 0 & 0 & 0 & 0 & 0 & 0,1 & 0,4 & 0,5 & 1,3 & 1,6 & 1,1 & 0 & 0 & 0 \\
\hline
\end{tabular} \begin{tabular}{lllllllllllllllllllllllll}
\hline ESPORT3 & 0 & 0 & 0 & 0 & 0 & 0 & 0 & 0 & 0 & 0 & 0 & 0 & 0 & 0 & 0 & 0 & 0 & 0 & 0 & 0,9 & 1,1 & 1,4 & 1,2 & 1,2 \\
\hline
\end{tabular} \begin{tabular}{lllllllllllllllllllllllllll}
\hline GRUPO TV3 & 27,6 & 24,8 & 27,7 & 25,7 & 26 & 29,1 & 29,3 & 27,3 & 26,3 & 27,9 & 28,4 & 27,9 & 26,1 & 24,9 & 22,8 & 20,6 & 18,4 & 17,6 & 18,8 & 19,3 & 18,9 & 16,1 & 15,1 & 15,2
\end{tabular} \begin{tabular}{llllllllllllllllllllllllll}
\hline ETB1 & 4,3 & 5,5 & 5,1 & 5,9 & 6,7 & 7,5 & 6,7 & 5,4 & 4,6 & 5,3 & 5,6 & 6,2 & 5,3 & 5 & 4,4 & 3,7 & 3,4 & 3,2 & 2,2 & 2 & 2,1 & 2,1 & 2 & 1,9 \\
\hline
\end{tabular} \begin{tabular}{llllllllllllllllllllllllll}
\hline ETB2 & 9,4 & 10,7 & 12,4 & 14,8 & 16,1 & 17,2 & 16,5 & 15,6 & 16,3 & 17,8 & 18,5 & 18 & 17,1 & 18,4 & 15,8 & 14,8 & 15,1 & 13,4 & 9,4 & 8,2 & 9,9 & 9,6 & 9 & 8,9 \\
\hline
\end{tabular}

ETB3

GRUPO ETB

$\begin{array}{llllllllllllllllllllllll}0 & 0 & 0 & 0 & 0 & 0 & 0 & 0 & 0 & 0 & 0 & 0 & 0 & 0 & 0 & 0 & 0,1 & 0,3 & 0,5 & 0,7 & 0,9 & 0,9 & 0,9 & 0,6\end{array}$
\begin{tabular}{lllllllllllllllllllllllll}
\hline TELEMADRID & 18,4 & 18,8 & 17,8 & 20 & 19 & 20,3 & 20,6 & 20 & 19,7 & 17,8 & 17,2 & 17,1 & 14,9 & 14,4 & 11,6 & 10,5 & 10,5 & 9,7 & 8 & 6,4 & 5,3 & 3,8 & 4,2 & 4,1 \\
\hline
\end{tabular} \begin{tabular}{lllllllllllllllllllllllll}
\hline LAOTRA & 0 & 0 & 0 & 0 & 0 & 0 & 0 & 0 & 0 & 0 & 0 & 0 & 0 & 0 & 0,1 & 0,2 & 0,3 & 0,4 & 0,7 & 0,8 & 0,9 & 0,7 & 0,8 & 0,8 \\
\hline
\end{tabular}

\begin{tabular}{lllllllllllllllllllllllll}
\hline GRUPO TVM & 18,4 & 18,8 & 17,8 & 20 & 19 & 20,3 & 20,6 & 20 & 19,7 & 17,8 & 17,2 & 17,1 & 14,9 & 14,4 & 11,7 & 10,7 & 10,8 & 10,1 & 8,7 & 7,2 & 6,2 & 4,5 & 5 & 4,9
\end{tabular}
\begin{tabular}{lllllllllllllllllllllllll}
\hline $\mathrm{Cg**}$ & 23,5 & 19,9 & 17,7 & 18,5 & 17,3 & 20,6 & 18,2 & 18,7 & 20,2 & 18,7 & 18,4 & 18,2 & 17 & 16,3 & 14,3 & 12,7 & 12 & 11,8 & 8,4 & 6 & 5 & 3,7 & 0 & 0
\end{tabular} \begin{tabular}{llllllllllllllllllllllllll}
\hline NOUDOS** & 0 & 0 & 0 & 0 & 0 & 0,1 & 0,9 & 1,4 & 2 & 2 & 1,8 & 2 & 2,1 & 2,4 & 2,1 & 1,8 & 1,3 & 0,6 & 0,5 & 0,4 & 0,4 & 0,2 & 0 & 0
\end{tabular} \begin{tabular}{lllllllllllllllllllllllll}
\hline NOU24** & 0 & 0 & 0 & 0 & 0 & 0 & 0 & 0 & 0 & 0 & 0 & 0 & 0 & 0 & 0 & 0 & 0 & 0,5 & 0,3 & 0,3 & 0,3 & 0,4 & 0 & 0 \\
\hline
\end{tabular} \begin{tabular}{llllllllllllllllllllllllll}
\hline GRUPO TVV & 22,5 & 19,9 & 17,7 & 18,5 & 17,3 & 20,7 & 19,1 & 20,1 & 22,2 & 20,7 & 20,2 & 20,2 & 19,1 & 18,7 & 16,4 & 14,5 & 13,3 & 12,9 & 9,2 & 6,7 & 5,7 & 4,3 & 0 & 0
\end{tabular} \begin{tabular}{lllllllllllllllllllllllllll}
\hline CMT & 0 & 0 & 0 & 0 & 0 & 0 & 0 & 0 & 0 & 0 & 7,3 & 11,1 & 11,6 & 12,8 & 12 & 11,1 & 10,2 & 10,3 & 7,5 & 6,4 & 5,1 & 4,4 & 4,6 & 4,3
\end{tabular} \begin{tabular}{lllllllllllllllllllllllll}
\hline CMT2** $^{* *}$ & 0 & 0 & 0 & 0 & 0 & 0 & 0 & 0 & 0 & 0 & 0 & 0 & 0 & 0 & 0 & 0 & 0 & 0,2 & 0,7 & 0,6 & 0 & 0 & 0 & 0 \\
\hline
\end{tabular} \begin{tabular}{lllllllllllllllllllllllll}
\hline GRUPO CMT & 0 & 0 & 0 & 0 & 0 & 0 & 0 & 0 & 0 & 0 & 7,3 & 11,1 & 11,6 & 12,8 & 12 & 11,1 & 10,2 & 10,5 & 8,2 & 7 & 5,1 & 4,4 & 4,6 & 4,3 \\
\hline
\end{tabular}

\begin{tabular}{lllllllllllllllllllllllll}
\hline TVCAN & 0 & 0 & 0 & 0 & 0 & 0 & 0 & 0,8 & 5,4 & 7,1 & 11,1 & 12,7 & 10,3 & 9,9 & 9,2 & 9,3 & 10,2 & 11,6 & 10 & 7,9 & 7,6 & 7,2 & 7,3 & 7
\end{tabular}

\begin{tabular}{llllllllllllllllllllllllll}
\hline TVCAN2** $^{2}$ & 0 & 0 & 0 & 0 & 0 & 0 & 0 & 0 & 0 & 0 & 0 & 0 & 0 & 0 & 0 & 0 & 0,2 & 0,6 & 1 & 1 & 0,5 & 0 & 0 & 0
\end{tabular}

\begin{tabular}{lllllllllllllllllllllllll}
\hline GRUPO TVCAN & 0 & 0 & 0 & 0 & 0 & 0 & 0 & 0,8 & 5,4 & 7,1 & 11,1 & 12,7 & 10,3 & 9,9 & 9,2 & 9,3 & 10,4 & 12,2 & 11 & 8,9 & 8,1 & 7,2 & 7,3 & 7
\end{tabular}
\begin{tabular}{lllllllllllllllllllllllllll}
\hline ARAGON TV & 0 & 0 & 0 & 0 & 0 & 0 & 0 & 0 & 0 & 0 & 0 & 0 & 0 & 0 & 4,7 & 6,7 & 8,8 & 9,6 & 9,4 & 10,7 & 11,3 & 11,5 & 11,3 & 11,1
\end{tabular}

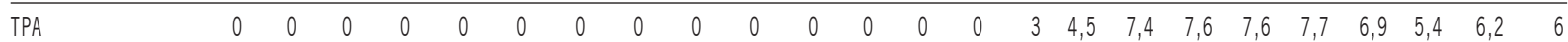

\begin{tabular}{lllllllllllllllllllllllll}
\hline TPA2 & 0 & 0 & 0 & 0 & 0 & 0 & 0 & 0 & 0 & 0 & 0 & 0 & 0 & 0 & 0 & 0 & 0,1 & 0,3 & 0,8 & 0,8 & 0,8 & 0,7 & 0,7 & 0,7
\end{tabular}

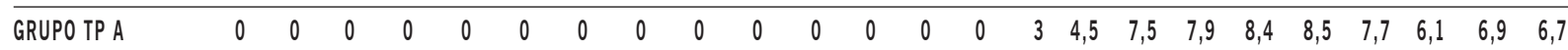

\begin{tabular}{lllllllllllllllllllllllll}
\hline IB3 & 0 & 0 & 0 & 0 & 0 & 0 & 0 & 0 & 0 & 0 & 0 & 0 & 0 & 0 & 6,7 & 6,5 & 4,7 & 5,1 & 5,5 & 5,2 & 6,3 & 5,9 & 5,8 & 6,1 \\
\hline
\end{tabular}

\begin{tabular}{lllllllllllllllllllllllll}
\hline $7 \mathrm{RM} * *$ & 0 & 0 & 0 & 0 & 0 & 0 & 0 & 0 & 0 & 0 & 0 & 0 & 0 & 0 & 1,5 & 2,8 & 4,1 & 5,2 & 4,6 & 4 & 2,5 & 0,5 & 0 & 0
\end{tabular}

\begin{tabular}{llllllllllllllllllllllllllll}
\hline AUTONÓMICAS & 16,5 & 15,6 & 15,1 & 15,5 & 15,3 & 16,9 & 16,6 & 16,4 & 17 & 17,2 & 17,9 & 18,4 & 17,7 & 17,6 & 15,4 & 14,7 & 14,5 & 13,6 & 11,3 & 10,4 & 9,8 & 8,7 & 8 & 7,7 \\
\hline
\end{tabular}

* 2015: Datos ata o 28/02/2015 inclusive

** Canles desaparecidas no 2015 
6. - A sustentabilidade e independencia do financiamento do servizo público audiovisual requiren novas fontes de ingresos máis aló da crise fiscal e publicitaria. O documento da BBC, que ata agora dispuxo do sistema máis estable e independente de financiamento, abriu o debate a novas fontes e alternativas. 0 modelo de negocio do servizo público audiovisual, que é social e non económico, ten que contemplar as posibilidades que ofrece Internet e, entre elas, o pago por visión e a subscrición. Polo momento, esas posibilidades están acoutadas pola comunicación europea de 2009, derivada do Protocolo de Amsterdam de 1997. Outra alternativa sería poñer enriba da mesa a comercialización de contidos premium e a corresponsabilidade de financiamento cívico -a través de crowfunding ou membresía de subscrición- para reforzar o servizo público e contrarrestar a manipulación político partidista da súa independencia. A crise fiscal dos estados dos últimos anos viuse reflectida na contención dos orzamentos das televisión públicas.

Cadro 9. Orzamentos das RTV públicas europeas

\begin{tabular}{|c|c|c|c|c|c|c|c|}
\hline Países & RTV & 2008 & 2009 & 2010 & 2011 & 2012 & 2013 \\
\hline Alemaña & ARD/ZDF & 8469,2 & 8745,9 & 8740,8 & 8867,2 & 8523,4 & $4180 \mathrm{ZDF}$ \\
\hline Austria & $\mathrm{ORF}$ & 1044,8 & 971,1 & 971,2 & 991,5 & 1001,9 & - \\
\hline Bélxica & VRT/RTBF/BRF & 783,8 & 799 & 787,8 & 776,5 & 796,6 & 323 RTBF \\
\hline Chipre & CyBC & 43,3 & 35,8 & 45 & 36,8 & 37,7 & - \\
\hline Croacia & HRT & - & 192,2 & 193,3 & 187,6 & 189,9 & - \\
\hline Dinamarca & $\mathrm{DR}$ & 786,4 & 763 & 805,8 & 828,6 & 872,6 & - \\
\hline Eslovaquia & RTVS & 103,6 & 103 & 101,9 & 114,1 & 97,4 & 121,8 \\
\hline Eslovenia & RTVSLO & - & 128,8 & 133,5 & 130,7 & 131,7 & \\
\hline España & RTVE/FORTA & 2675 & 2871 & 2794 & 2572 & 2165 & 1955,37 \\
\hline Estonia & ERR & 32,1 & 29,7 & 28,4 & 28,3 & 28,5 & 27,6 \\
\hline Finlandia & YLE & 397,5 & 411,2 & 420,1 & 432,5 & 456,1 & 469,1 \\
\hline Francia & FT & 4020,6 & 4246,7 & 4375,5 & 4443,1 & 4207 & - \\
\hline Grecia & ERT & 366 & 366,3 & 386 & 328,8 & - & - \\
\hline Hungría & MTV & - & 184,3 & 158 & 290 & 296,8 & - \\
\hline Irlanda & RTÉ & 440,8 & 374,9 & 371,7 & 350,9 & 337,2 & 327,6 \\
\hline Italia & RAI & 3315 & 3208 & 3040 & 2998 & 2761 & 2561,7 \\
\hline Lituania & LRT & 26,3 & 19,4 & 17,3 & 19 & 20,7 & 20,4 \\
\hline Malta & PBS & 6068 & 5832 & 8215 & 9071 & - & - \\
\hline Países Baixos & NPO & 815,1 & 829,2 & 857,2 & 855,9 & 864,5 & 799,2 \\
\hline Polonia & TVP & - & 489,5 & 497,5 & 475,7 & 393,1 & \\
\hline Portugal & RTP & 298,5 & 305,6 & 308,7 & 318,1 & 259 & 234,7 \\
\hline Reino Unido & BBC & - & 7850,3 & 7830,2 & 8091,3 & 7746,1 & 6439,5 \\
\hline R. Checa & CT & 330,6 & 333,3 & 337 & 321,9 & 316,5 & 246 \\
\hline Romanía & TVR & 205,6 & 211,7 & 211,4 & 215,8 & - & - \\
\hline Suecia & SVT & 711,7 & 694 & 751,5 & 756,8 & 786,9 & 792 \\
\hline
\end{tabular}

Fonte: elaboración propia a partir do Observatorio Audiovisual Europeo, 2014. Datos en millóns de euros e moedas locais dos países que non teñen a divisa europea.

7.- Reconverter as corporacións e canles de radiotelevisión en plataformas converxentes de comunicación. 0 modelo estrutural e organizativo de hai 25 anos é ineficiente e insostible hoxe en día. A estrutura e xestión das cor- 
poracións públicas ten que evolucionar cara a un ecosistema empresarial integrado por distintas unidades produtivas internas e externas, tanto profesionais como formadas polos seus propios usuarios. Deberán integrar radio, televisión, espazos web e redes sociais nunha mesma plataforma ou ecosistema converxente de xestión da información, entretemento e comunicación de múltiples colaboracións. O proxecto da nova Carta Real da BBC critica a burocracia e corporativismo ao mesmo tempo que abre a porta á privatización dalgunhas das súas unidades produtivas.

A clásica división de produción propia e allea, interna e externa, perde sentido nese novo ecosistema converxente porque todo pasa a ser propio, interno e externo ao mesmo tempo, pásase da metáfora de xestión da factoría á da torre de control do aeroporto. Evidentemente, esta concepción revoluciona e cambia a estrutura organizativa tradicional de forma radical. Quedan con pouco sentido os modelos departamentais, xerárquicos e matriciais, fronte ás necesidades de estímulos e necesidades horizontais de coordinación dos equipos operativos.

8.- Reconversión ou refundación do modelo. O dilema é máis teórico que práctico. A refundación, sen dúbida, podería ser teoricamente máis fácil que a reconversión pero, para empezar de novo, é necesario, primeiro, facer borrón e deseñar a conta nova. Xa imos vendo o que ocorre coas empresas que cerraron e volven empezar (casos de Grecia e Valencia). Xa imos vendo se a refundación só significa continuar cos vicios anteriores. Xa veremos como é a rexeneración. A rexeneración e a reconversión son posibilistas, porque dependen da vontade, pero non son máis fáciles nin menos complexas.

Para afrontar a reconversión, as corporacións públicas actuais teñen sobre elas catro pesadas lousas: unha regulación ríxida e anticuada, unhas bases de financiamento inestables cada vez máis axustadas, unhas pesadas infraestruturas técnicas obsoletas e uns cadros laborais sobrecargados, envellecidos e desaxeitados para afrontar o reto da converxencia dixital.

9.- A creatividade e a innovación como valores dinámicos de renovación do servizo público. Son elementos esenciais para a renovación do modelo e a innovación forma parte dos seis valores establecidos pola UER para o seu esquema de 24 indicadores de avaliación das probas de valor público. Eses seis principios da proba de valor público son a universalidade, excelencia, independencia, diversidade, innovación e rendición de contas. Estas probas son realizadas actualmente por seis televisións públicas europeas (BBC, ZDF, ARD, RTBF, DR, YLE y RAI) e outras doce elaboran tamén memorias de Responsabilidade Social Corporativa (ZDF, ORF, RTBF, RTVE, CRTVG, CMAC, EITB, YLE, FTV, RTE, RTP e BBC).

10.- Reforzo do discurso, presenza e representación institucional do servizo público audiovisual a nivel estatal e global. Refundada, reconvertida ou pendente de rexeneración, a radiotelevisión pública e o servizo audiovisual público necesitan reforzar tanto o seu discurso sobre a súa necesidade e defensa como a súa presenza e representación institucional. 0 discurso de rexeneración e defensa revitalizouse na Academia, mais languidece tanto na sociedade coma na propia gobernanza. Talvez por falta de capacidade de estratexia, escenarios e alternativas. Non obstante, os retos están reclamando novos movementos estratéxicos. A competitividade comercial e a representación diante de Bruxelas esixen maior eficacia da UER e esta debería abrirse definitivamente tamén aos pequenos operadores públicos rexionais e locais. No caso de España, as autonómicas de FORTA e a RTVE estatal deberían converxer nunha mesma plataforma de representación e distribución global.

\section{A INDUSTRIA DA COMUNICACIÓN EN GALICIA}

O panorama económico da industria da comunicación en Galicia nos últimos cinco anos, á vista das contas de resultados das súas principais empresas presentadas diante do Rexistro Mercantil, non é mellor nin moi diferente, na súa escala, das tendencias xerais de carácter global. No período de 2007 a 2012, a industria da comunicación en Galicia, se descartamos a facturación da empresa de telecomunicacións R, rexistrou un descenso da súa actividade económica dun 25 por cento, ao pasar de 337 millóns de euros a 225 millóns, respectivamente. A caída foi máis grande na radio e na prensa, con descensos do $51,6 \%$ e $36,25 \%$. 
Pero os problemas destas industrias, mirando cara ao escenario dos próximos dez anos, tampouco son menores no plano estratéxico que no económico. Entre eles pódense enumerar a falla de proxección estratéxica para a transición dixital, horizontes limitados e problemas de sucesión no liderado das principais empresas, carencias de fortaleza para a formación do capital necesario para acometer novos investimentos, forte apancamento e limitada capacidade de xeración de recursos para reducir os seus endebedamentos, pouca forza de creatividade e innovación, estruturas pesadas e burocráticas e perda de penetración (audiencias) da súa capacidade competitiva nos mercados de proximidade. A iso poderíase engadir a carencia de políticas institucionais de longo alcance, máis aló das solucións e rutinas conxunturais, para visualizar a situación e dependencia do sector no escenario do ano 2020.

Cadro 10. Resultados dos medios de Galicia, 2007-2014

\begin{tabular}{lrrrrrrrrrrrr}
\multicolumn{1}{c}{ Empresa } & \multicolumn{10}{c}{ Ingresos } \\
\hline Anos & 2013 & 2012 & 2011 & 2008 & 2007 & 2013 & 2014 & 2012 & 2011 & 2008 & 2007 & 2014 \\
\hline Grupo R & 239489 & 238157 & 230463 & 182922 & 134093 & 8081 & 234600000 & 12270 & 16717 & 14611 & 12053 & 92000000 \\
\hline CRTVG & 107900 & 117100 & 121500 & 131700 & 122900 & 1500 & 99470030 & 530 & 210 & 371 & 3700 & 312362 \\
\hline Voz Galicia & 52942 & 56451 & 60335 & 78308 & 83880 & 681 & 52591698 & 522 & -2487 & 2010 & 7368 & 862861 \\
\hline Faro de Vigo & 21101 & 22098 & 24749 & 28821 & 31276 & 204 & 20562119 & 1071 & 1972 & 3335 & 4979 & 1573798 \\
\hline Ed. Compostela & 14661 & 21518 & 22242 & 27196 & 28468 & -1017 & 14460490 & -1123 & -1375 & 367 & 343 & -1049600 \\
\hline La Región & 7847 & 8798 & 12064 & 13191 & 14894 & 174 & n. d. & -48 & 637 & 189 & 128 & n. d. \\
\hline El Progreso & - & - & 13094 & 16083 & 15819 & - & 11013164 & - & -201 & 731 & 854 & -316714 \\
\hline Lérez Edics. & 4069 & 4987 & 5095 & 5614 & 5547 & -272 & 3974913 & 52 & 218 & 107 & 69 & -245077 \\
\hline La Capital & 5448 & 6065 & 6612 & 7598 & 8400 & -646 & 5199397 & -842 & -621 & -250 & 324 & -706556 \\
\hline La Opinión & 3074 & 3289 & 3544 & 4710 & 5139 & -340 & 2735712 & -479 & -769 & -275 & 64 & -382334 \\
\hline Atlántico & - & 2209 & 3087 & 3031 & 3315 & - & $n . d$. & -416 & -403 & -515 & -392 & n. d. \\
\hline R Coruña & 1924 & 2315 & 2642 & 3464 & 3787 & -201 & 1946439 & 70 & 153 & 298 & 322 & -429431 \\
\hline R Lugo & 599 & 771 & 1003 & 1342 & 1415 & -259 & 705838 & -198 & -71 & 212 & 27 & -157716 \\
\hline R Orense & 709 & 919 & 949 & 1266 & 1327 & -48 & 790916 & 78 & 41 & 212 & 288 & 31366 \\
\hline R Pontevedra & 1572 & 1890 & 2076 & 2056 & 2190 & -174 & 1590977 & -83 & -98 & 181 & -395 & -5808 \\
\hline R Vigo & 1709 & 2417 & 2586 & 2938 & 3076 & 42 & 1739585 & 314 & 282 & 377 & 154 & 99089 \\
\hline Voz Radio & 1458 & 1922 & 2397 & 3399 & 3525 & -239 & 1671536 & -329 & -195 & 6 & 79 & -75774 \\
\hline R Principal & 278 & 302 & 359 & 415 & 419 & -39 & 288717 & -46 & -4 & 49 & 29 & -17706 \\
\hline C. Noroeste & 180 & 266 & 395 & 1704 & 1679 & -7 & n. d. & -7 & -287 & 11 & 8 & n. d. \\
\hline
\end{tabular}

Fonte: datos obtidos de SABI (Sistema de Análise de Balances Ibéricos), procedentes do Rexistro Mercantil. As cifras están en miles de euros. A sociedade de Atlántico Diario é Rías Baixas Comunicación SA, a de Ed. Compostela corresponde á cabeceira de El Correo Gallego, Lérez Edics. a Diario de Pontevedra e a de La Capital ao grupo de El Ideal Gallego.

A industria da comunicación en Galicia, incluíndo a actividade do Grupo R, que, ademais de telefonía e acceso a Internet, tamén presta servizos de difusión audiovisual, sumou 465 millóns de euros en 2013 fronte aos 471 millóns de 2007. Se descartamos os ingresos de explotación do grupo R, que en 2015 foi mercado por Eskaltel en 1190 millóns de euros, a facturación do resto da industria da comunicación baixou en 2014 a 218,74 millóns e os resultados pasaron a ser negativos en máis de medio millón de euros. 0 descenso do 4,3\% ascende ao $25 \%$ se descontamos a facturación de R e xuntamos a actividade audiovisual (da CRTVG e das produtoras audiovisuais), da prensa, da radio e da industria editorial, ao pasar de 337 millóns de euros de 2007 a 225,4 millóns de 2013. Ao sumar os seus resultados, en termos de beneficios ou perdas, pasan a ser negativos de 2011 a 2013. A perda 
de emprego neses sectores tamén é significativa porque acada o 13,4 \% ao baixar de 2716 postos de traballo de 2007 aos 2169 de 2013.

Hai que precisar que as cifras económicas que se recollen neste estudo e nas súas correspondentes táboas proceden das contas presentadas polas empresas diante do Rexistro Mercantil e procesadas polo Sistema de Análises de Balances Ibéricos (SABI). Naquelas epígrafes en que non se achegan cifras é por mor de que as empresas non presentaron eses datos diante do Rexistro Mercantil e que, polo tanto, non constan no sistema SABI.

Cadro 11. Emprego e endebedamento dos medios de Galicia

\begin{tabular}{lrrrrrrrrrrrr} 
Empresa & \multicolumn{10}{c}{ Emprego } \\
\hline Anos & 2013 & 2012 & 2011 & $\mathbf{2 0 0 8}$ & $\mathbf{2 0 0 7}$ & $\mathbf{2 0 1 4}$ & $\mathbf{2 0 1 3}$ & $\mathbf{2 0 1 2}$ & $\mathbf{2 0 1 1}$ & $\mathbf{2 0 0 8}$ & $\mathbf{2 0 0 7}$ & $\mathbf{2 0 1 4}$ \\
\hline CRTVG & 916 & 781 & 804 & 698 & 675 & 916 & 31,23 & 34,40 & 37,27 & 46,74 & 72,09 & 35 \\
\hline R Cable & 202 & 205 & 203 & 194 & 184 & - & 81,07 & 82,45 & 84,60 & 58,22 & 60,97 & - \\
\hline Voz Galicia & 328 & 358 & 411 & 545 & 540 & 316 & 40,17 & 44,60 & 45,16 & 43,42 & 53,84 & 32,76 \\
\hline Ed. Compostela & 154 & 170 & 199 & 209 & 199 & 178 & 87,52 & 91,84 & 87,80 & 82,47 & 81,81 & 96,53 \\
\hline La Región & 84 & 108 & 139 & 204 & 209 & 84 & 79,32 & 80,43 & 80,34 & 66,56 & 68,43 & 79,32 \\
\hline Faro Vigo & 146 & 160 & 160 & 177 & 184 & - & 24,17 & 26,60 & 23,15 & 26,67 & 31,56 & 28,33 \\
\hline El Progreso & 145 & 145 & 148 & 152 & 143 & 127 & - & - & 42,24 & 49,03 & 53,17 & 58,73 \\
\hline Lérez Edics. & 64 & 64 & 66 & 82 & 82 & 60 & 91,47 & 83,13 & 85,86 & 85,73 & 82,46 & 87,06 \\
\hline La Capital & 119 & 148 & 156 & 178 & 175 & 135 & 86,31 & 64,93 & 52,61 & 41,62 & 39,29 & 112,81 \\
\hline La Opinión & 44 & 51 & 59 & 74 & 75 & 42 & 51,27 & 71,76 & 93,13 & 70,70 & 61,78 & 52,88 \\
\hline Atlántico & 38 & 41 & 52 & 25 & 77 & n. d. & - & 72,37 & 56,30 & 131,34 & 105,7 & n. d. \\
\hline R Coruña & 26 & 30 & 31 & 38 & 38 & 23 & 45,13 & 40,47 & 36,73 & 33,64 & 31,94 & 74,23 \\
\hline R Lugo & 14 & 15 & 16 & 18 & 16 & 14 & 23,07 & 19,22 & 17,54 & 23,09 & 25,48 & 28,99 \\
\hline R Orense & 19 & 21 & 23 & 18 & - & 19 & 5,30 & 5,45 & 5,43 & 7,37 & 8,77 & 5,83 \\
\hline R Pontevedra & 14 & 17 & 17 & 21 & - & 14 & 37,04 & 15,76 & 19,80 & 27,91 & 37,07 & 30,77 \\
\hline R Vigo & 14 & 17 & 18 & 20 & 23 & 12 & 38,04 & 25,27 & 27,10 & 15,43 & 12,57 & 41,66 \\
\hline Voz Radio & 16 & 19 & 27 & 40 & 47 & 17 & 20,96 & 18,57 & 21,97 & 25,34 & 30,31 & 30,02 \\
\hline R Principal & 6 & 6 & 5 & 7 & 6 & 6 & 31,16 & 24,22 & 22,36 & 20,81 & 17,21 & 33,50 \\
\hline C. Noroeste & 3 & 14 & 16 & 42 & 43 & n. d. & 97,72 & 97,50 & 97,04 & 68,27 & 71,26 & n. d. \\
\hline & & & & & & & & & & &
\end{tabular}

Fonte: datos de $\mathrm{SABI}$ (que recolle do Rexistro Mercantil). As cifras están en miles de euros e as de débeda en porcentaxe.

A perda da actividade económica na prensa, radio e audiovisual, tomando como referencia os anos de 2007 e 2012 (por dispoñer de datos máis completos), está relacionada coa crise económica, co descenso no investimento publicitario e coa migración da economía do consumo analóxico ao dixital. Na radio a caída da actividade económica supera o $51 \%$, na prensa acada o $36 \%$, na produción audiovisual é do $35 \%$ e na industria editorial supera o $42 \%$. A perda de emprego na radio foi do $35 \%$, na prensa superou o $33 \%$ e no audiovisual chegou ao $26 \%$. As maiores cotas de apancamento financeiro corresponden ás organizacións de produción de editorial, case todas elas microempresas ou autónomos, seguidas das produtoras audiovisuais e das editoras de prensa. A radio segue a súa tradición de cotas máis baixas de endebedamento.

Os resultados da prensa impresa, con respecto ao conxunto de España, foron aínda peores que os de Galicia porque as súas vendas pasaron de 2426 millóns de euros en 2007 a 1176 millóns en 2013, o que significa unha caída do preto do 50 \% da súa facturación. E a súa conta de resultados agregada pasa de rexistrar 293 millóns de beneficios en 2007 a 64 millóns de perdas en 2012 e 29 millóns de recuperación positiva en 2013. 
A prensa en papel perdeu en Europa, entre 2009 e 2013, uns 39 millóns de exemplares de circulación diaria, un $17,45 \%$, segundo datos da Asociación Mundial de Diarios (WAN 2014). A prensa difunde diariamente no mundo uns 500 millóns de exemplares, dos cales 78,6 millóns corresponden a Europa (en 2009 eran 117,5 millóns). 0 afundimento da circulación da prensa impresa, tanto de pago como gratuíta, aínda foi maior en España porque pasou de 6,5 millóns de exemplares difundidos en 2009 a 2,6 millóns en 2013. Canto á difusión da prensa de pago, a baixada supera o 27 \%, ao pasar de 3537395 exemplares de 2008 aos 2568348 de 2013.

Cadro 12. Evolución da difusión da prensa

\begin{tabular}{lrrrrrrrr} 
Anos & $\mathbf{2 0 0 8}$ & $\mathbf{2 0 0 9}$ & $\mathbf{2 0 1 0}$ & $\mathbf{2 0 1 1}$ & $\mathbf{2 0 1 2}$ & $\mathbf{2 0 1 3}$ & $\mathbf{2 0 1 4}$ & $\mathbf{2 0 1 3 / 0 8}$ \\
\hline Total España & 3537395 & 3413657 & $3 \mathbf{3 9 4 7 2 7}$ & 3173279 & 2752460 & 2568348 & $1975006^{*}$ & $-27,39$ \\
\hline Total Galicia & 183586 & 179389 & 173886 & 166238 & 155797 & 144966 & 142792 & $-21,03$ \\
\hline Voz Galicia & 102858 & 100664 & 97016 & 91131 & 84843 & 80077 & $80077^{*}$ & $-22,14$ \\
\hline Faro de Vigo & 40336 & 39154 & 38004 & 36816 & 34804 & 31852 & 30234 & $-21,03$ \\
\hline El Progreso & 15846 & 15402 & 15258 & 14991 & 14219 & 13412 & $13412^{*}$ & $-15,36$ \\
\hline La Región & 11334 & 11324 & 11104 & 10906 & 10555 & 9200 & $9200^{*}$ & $-18,82$ \\
\hline D. Pontevedra & 7119 & 6917 & 6888 & 6867 & 6313 & 5742 & 5411 & $-19,34$ \\
\hline Opinión Coruña & 6093 & 5928 & 5616 & 5527 & 5063 & 4683 & 4458 & $-23,14$ \\
\hline
\end{tabular}

Fonte: datos dos xornais controlados por OJD. Compáranse os de 2008 e 2013 porque algúns de 2014 non están completos (*).

A difusión da prensa en Galicia, entre 2008 e 2013, baixou tamén por riba do 21 \%, aínda que tamén algo menos que no conxunto de España. Por cabeceiras, son as editadas na Coruña as que rexistran as porcentaxes máis altas de baixada. Tómanse como referencia, para os efectos comparativos, os datos de 2013 por non dispoñer das cifras completas de 2014 da Oficina de Justificación de la Difusión (OJD).

Botando man das enquisas do Estudio General de Medios (EGM), podemos calibrar o impacto do consumo e a audiencia de cada un dos principais medios de comunicación. O consumo de prensa diaria en España entre 2008 e 2014, segundo os datos do EGM, baixou do $42,1 \%$ ao 29,8 \%, respectivamente. Case unha mesma tendencia rexistran os suplementos e revistas. Polo contrario, subiu de forma importante o consumo de radio, sobre todo a de carácter temático. Tamén sobe o consumo de televisión e o uso de Internet.

Cadro 13. Consumo de medios, 2008-2014

\begin{tabular}{lrrrrrrr} 
Anos & $\mathbf{2 0 0 8}$ & $\mathbf{2 0 0 9}$ & $\mathbf{2 0 1 0}$ & $\mathbf{2 0 1 1}$ & $\mathbf{2 0 1 2}$ & $\mathbf{2 0 1 3}$ & $\mathbf{2 0 1 4}$ \\
\hline Universo & 38261 & 39462 & 39435 & 39485 & 39449 & 39331 & 39681 \\
\hline Diarios & 42,1 & 39,8 & 38,0 & 37,4 & 36,1 & 32,4 & 29,8 \\
\hline Suplementos & 21,7 & 21,9 & 19,2 & 18,2 & 16,2 & 14,6 & 12,7 \\
\hline Revistas & 53,3 & 51,3 & 50,4 & 48,9 & 45,4 & 43,4 & 41,0 \\
\hline Total radio & 53,1 & 55,3 & 56,9 & 58,5 & 61,9 & 61,5 & 61,0 \\
\hline Radio xeralista & 27,9 & 27,9 & 27,8 & 28,3 & 30,2 & 29,2 & 28,7 \\
\hline Radio temática & 28,5 & 31,1 & 33,0 & 34,6 & 37,3 & 37,4 & 37,4 \\
\hline Radio por Internet & 4,1 & 3,9 & 3,5 & 3,4 & 3,4 & 2,9 & 2,9 \\
\hline Televisión & 49,0 & 51,0 & 52,4 & 53,8 & 56,9 & 56,5 & 55,9 \\
\hline Internet (últ. 30 días) & 45,4 & 49,3 & 53,0 & 57,1 & 60,4 & 64,5 & 69,3 \\
\hline
\end{tabular}

Fonte: datos en porcentaxes e miles de persoas do universo poboacional do Estudio General de Medios. 
O fenómeno da prensa gratuíta foi un raio de sol que luciu mentres non chegou a crise da economía e da publicidade en 2008. Nese momento, as cabeceiras da prensa gratuíta comezaron a caer como follas secas en outono. No consumo xeral de prensa, a partir da eclosión da crise económica, destaca a caída dos xornais gratuítos en papel, ao mesmo tempo que a desaparición da maioría das súas cabeceiras, o estancamento da de información xeralista e a resistencia da deportiva.

Os xornais locais e de cobertura galega manteñen certa estabilidade pero non logran incrementar as súas cotas de audiencia mentres perden difusión no reconto da súa circulación a través da OJD. 0 certo é tamén que o número de lectores de prensa en Galicia descende a partir de 2012, fenómeno que tamén se aprecia no conxunto de España, pero a partir de 2013.

Cadro 14. Audiencia da prensa en Galicia

$\begin{array}{lllllllllll}2004 & 2005 & 2006 & 2007 & 2008 & 2009 & 2010 & 2011 & 2012 & 2013 & 2014\end{array}$

\begin{tabular}{|c|c|c|c|c|c|c|c|c|c|c|c|}
\hline Pob. España & 36408 & 37084 & 37439 & 37911 & 38261 & 39462 & 39435 & 39485 & 39449 & 39331 & 39681 \\
\hline Lectores España & 14980 & 15252 & 15660 & 15664 & 16102 & 15725 & 14994 & 14782 & 14223 & 12752 & 11809 \\
\hline Inf. xeral & 13534 & 13823 & 14211 & 14193 & 14547 & 13897 & 13127 & 12819 & 12353 & 10974 & 10146 \\
\hline Pob. Galicia & 2415 & 2422 & 2415 & 2422 & 2418 & 2447 & 2442 & 2436 & 2431 & 2414 & 2441 \\
\hline Lectores Galicia & 1158 & 1144 & 1259 & 1155 & 1194 & 1185 & 1132 & 1173 & 1152 & 1086 & 1068 \\
\hline Inf. xeral Galicia & 1114 & 1093 & 1210 & 1109 & 1132 & 1130 & 1062 & 1100 & 1095 & 1024 & 1011 \\
\hline Deportivos & 301 & 295 & 276 & 269 & 286 & 315 & 313 & 335 & 333 & 325 & 293 \\
\hline Gratuítos & 39 & 134 & 148 & 154 & 187 & 98 & 53 & 59 & 52 & & \\
\hline La Voz & 677 & 570 & 663 & 580 & 600 & 591 & 582 & 619 & 621 & 580 & 603 \\
\hline Faro Vigo & 301 & 290 & 290 & 267 & 274 & 273 & 268 & 267 & 285 & 259 & 279 \\
\hline Marca & 246 & 232 & 225 & 223 & 234 & 258 & 246 & 255 & 263 & 275 & 237 \\
\hline Que & & 116 & 137 & 126 & 143 & 48 & & & & & \\
\hline El País & 108 & 83 & 99 & 105 & 117 & 137 & 119 & 134 & 145 & 138 & 112 \\
\hline Progreso & 101 & 94 & 102 & 90 & 100 & 102 & 93 & 90 & 99 & 94 & 97 \\
\hline 20 Minutos & & & 98 & 101 & 148 & 83 & 46 & 55 & 45 & & \\
\hline Correo Gallego & 92 & 81 & 90 & 83 & 81 & 93 & 79 & 82 & 84 & 73 & 62 \\
\hline Mundo & 86 & 67 & 76 & 65 & 65 & 76 & 63 & 63 & 82 & 62 & 60 \\
\hline Región & 78 & 78 & 84 & 88 & 84 & 79 & 81 & 83 & 79 & 85 & 75 \\
\hline As & 57 & 64 & 58 & 62 & 83 & 79 & 83 & 87 & 90 & 93 & 86 \\
\hline Metro & 52 & 73 & 81 & & & & & & & & \\
\hline Diario Pontevedra & 46 & & & 50 & 38 & 45 & 44 & 43 & 47 & 46 & 45 \\
\hline Diario Ferrol & 44 & 30 & 29 & 28 & 33 & 24 & 31 & 26 & 25 & 31 & 27 \\
\hline Sport & 40 & 34 & 28 & 33 & 26 & 34 & 40 & 49 & 51 & 35 & 41 \\
\hline Opinión & 36 & 34 & 45 & & & & & & & 38 & 35 \\
\hline Deporte Campeón & 33 & 35 & 20 & & 13 & & & & & & 15 \\
\hline Ideal Gallego & 30 & 35 & 34 & 20 & 25 & 33 & 19 & 26 & 21 & 31 & 17 \\
\hline Atlántico & 29 & 25 & 18 & 18 & 18 & 13 & 18 & 17 & 16 & 14 & 18 \\
\hline$A B C$ & 20 & & 15 & & 18 & 19 & 23 & 25 & 23 & 18 & 17 \\
\hline SuperDepor & & & 13 & & & & & & & & \\
\hline Diar. Arousa & & & 13 & 15 & 14 & & & 16 & 17 & 12 & \\
\hline Mundo Deportivo & & & 13 & & & & 14 & 17 & 15 & 13 & 16 \\
\hline$A D N$ & & & & 64 & 80 & 48 & & & & & \\
\hline Luns Venres & & & & 30 & 35 & & 28 & 28 & 38 & & \\
\hline
\end{tabular}

Fonte: elaboración propia, con cifras en miles, a partir do Estudio General de Medios. 
Fronte á perda de audiencia da prensa, que se corresponde coa tendencia de descenso do seu consumo, aumenta a da radio en xeral, tanto a nivel de España como en Galicia. Pero ese incremento non está protagonizado pola radio xeralista, senón pola de carácter temático. Esta tendencia apunta a que os receptores dos medios tradicionais perden máis interese polos contidos de información xeral que polos de entretemento e especialización, especialmente os de ámbito deportivo.

Cadro 15. Audiencia da radio en Galicia

\begin{tabular}{lrrrrrrrrrrrrr} 
Emisoras & $\mathbf{2 0 0 2}$ & $\mathbf{2 0 0 3}$ & $\mathbf{2 0 0 4}$ & $\mathbf{2 0 0 5}$ & $\mathbf{2 0 0 6}$ & $\mathbf{2 0 0 7}$ & $\mathbf{2 0 0 8}$ & $\mathbf{2 0 0 9}$ & $\mathbf{2 0 1 0}$ & $\mathbf{2 0 1 1}$ & $\mathbf{2 0 1 2}$ & $\mathbf{2 0 1 3}$ & $\mathbf{2 0 1 4}$ \\
\hline Poboación & 2371 & 2401 & 2436 & 2422 & 2416 & 2422 & 2418 & 2447 & 2442 & 2436 & 2431 & 2414 & 2441 \\
\hline Audiencia & 1334 & 1428 & 1398 & 1345 & 1415 & 1413 & 1358 & 1410 & 1492 & 1502 & 1596 & 1521 & 1527 \\
\hline Xeralista & 813 & 859 & 890 & 809 & 807 & 788 & 749 & 784 & 770 & 799 & 863 & 802 & 780 \\
\hline Ser & 381 & 407 & 416 & 335 & 357 & 355 & 318 & 373 & 347 & 332 & 330 & 343 & 336 \\
\hline Onda Cero & 98 & 130 & 121 & 110 & 120 & 95 & 124 & 116 & 133 & 139 & 143 & 130 & 108 \\
\hline RNE 1 & 77 & & & 78 & 69 & 68 & 53 & 68 & 54 & 90 & 94 & 68 & 58 \\
\hline COPE & 135 & 124 & 147 & 161 & 138 & 142 & 137 & 121 & 103 & 126 & 148 & 135 & 167 \\
\hline R. Galega & 134 & 139 & 149 & 168 & 175 & 165 & 149 & 121 & 158 & 147 & 173 & 174 & 143 \\
\hline Radio Voz & & & 31 & 40 & 27 & 27 & 36 & 30 & 30 & 46 & 53 & 39 & 52 \\
\hline Temática & 547 & 602 & 587 & 606 & 662 & 716 & 629 & 717 & 840 & 797 & 876 & 847 & 862 \\
\hline C40 & 208 & 200 & 161 & 206 & 262 & 242 & 255 & 248 & 261 & 244 & 243 & 235 & 216 \\
\hline Dial & 150 & 136 & 116 & 129 & 110 & 123 & 97 & 92 & 96 & 102 & 118 & 104 & 109 \\
\hline C100 & 60 & 70 & 67 & 68 & 57 & 97 & 136 & 176 & 191 & 194 & 184 & 174 & 175 \\
\hline Kyss & 18 & 27 & 38 & 43 & 37 & 37 & 48 & 35 & 44 & 33 & 49 & 39 & 34 \\
\hline M80 & 56 & 64 & 88 & 77 & 77 & 78 & 50 & 50 & 51 & 45 & 46 & 45 & 35 \\
\hline Máxima & & 24 & 35 & 21 & 12 & 19 & 18 & 39 & 37 & 56 & 23 & 16 & 16 \\
\hline RNE 3 & 17 & & & & 34 & 22 & 22 & 15 & 28 & 31 & 29 & 26 & 33 \\
\hline Europa FM & 6 & 28 & 31 & 27 & 53 & 62 & 80 & 99 & 111 & 112 & 125 & 122 & 113 \\
\hline RG Música & & & & & & & & & 17 & 15 & 16 & 13 & 17 \\
\hline RNE5tn & 52 & & & 46 & 36 & 48 & 34 & 26 & 36 & 21 & 35 & 28 & 26 \\
\hline R. Marca & & 7 & 13 & 22 & 25 & 30 & 30 & 26 & 36 & 41 & 37 & 28 & 20 \\
\hline
\end{tabular}

Fonte: elaboración propia con cifras en miles de persoas, a partir do Estudio General de Medios.

Os cinco primeiros anos da segunda década do século xx son de grandes movementos no sector audiovisual pola repercusión da crise económica, os cambios no marco regulatorio e as transformacións tecnolóxicas. No ano 2013, a radio española rexistra os peores resultados económicos dos últimos dez anos (318 millóns de euros fronte a 391,6 millóns en 2010). Nese mesmo ano desaparece o cuarto operador nacional privado, prodúcese a adquisición pola Cope das emisores de ABC Punto Radio (grupo Vocento). As tres grandes cadeas (SER, Onda Cero-Uniprex e Cope) suman o 95,3 \% do negocio publicitario radiofónico. A concentración en televisión prodúcese pola absorción da publicidade de RTVE (a partir de 2010), a fusión de Telecinco e Cuatro (2011), Antena 3 e La Sexta (2012). Mediaset e A3Media pasan a controlar o $88 \%$ do mercado publicitario e o 57,7 da audiencia.

Neste último quinquenio prodúcese o primeiro apagamento analóxico (2010) e a segunda (2015) migración das emisións televisivas dixitais terrestres; a entrada en vigor da Lei xeral do audiovisual (7/2010); a aprobación da nova lei dos medios de comunicación audiovisual públicos de Galicia (9/2011); a supresión da publicidade en RTVE (Lei 8/2009) e o cambio no sistema de gobernanza desa corporación (2012); a flexibilización dos modos de xestión das radiotelevisións autonómicas (Lei 6/2012); a integración de Telecinco e Cuatro para formar 
Mediaset España; a absorción de La Sexta por Antena 3 en A3Media; a creación das plataformas de televisión online Mitele de Mediaset, A3 Player de A3M e Yomvi de Canal Plus; o peche de emisións de Canal 9 de Valencia (2013); a anulación polo Tribunal Supremo da concesión en 2010 dun múltiple completo de TDT a Antena 3, Telecinco, Sogecable, Veo7, Net TV e La Sexta; o peche de emisións (2014) de Net TV (Vocento) e Veo (Unedisa); e a adquisición de Ono por Vodafone (2013), de Canal Plus por Telefónica e do Grupo R por Euskaltel (en 2015). Os cambios legais, a crise económica e a concentración da publicidade repercuten de forma notoria nos orzamentos das radiotelevisións autonómicas.

Cadro 16. Orzamentos das RTVP autonómicas, 2007-2014

\begin{tabular}{|c|c|c|c|c|c|c|c|c|}
\hline \multirow[t]{2}{*}{ RTV de FORTA } & \multicolumn{2}{|c|}{2007} & \multicolumn{2}{|c|}{2008} & \multicolumn{2}{|c|}{2009} & \multicolumn{2}{|c|}{2010} \\
\hline & Orzam. & Subv. & Orzam. & Subv. & Orzam. & Subv. & Orzam. & Subv. \\
\hline Andalucía & 229,024 & 165,910 & 243,285 & 177,388 & 247,324 & 181,838 & 238,982 & 172,940 \\
\hline Cataluña & 393,888 & 217,205 & 378,409 & 206,079 & 383,805 & 226,255 & 390,566 & 256,070 \\
\hline Madrid & 157,053 & 85,293 & 161,724 & 89,579 & 143,284 & 89,564 & 150,792 & 111,341 \\
\hline Valencia & 276,819 & 188,912 & 309,146 & 219,217 & 238,561 & 150,506 & 182,280 & 141,452 \\
\hline Galicia & 122,953 & 97,139 & 131,790 & 103,808 & 134,183 & 106,999 & 138,049 & 102,168 \\
\hline P. Vasco & 183,327 & 121,324 & 173,733 & 139,072 & 183,723 & 148,920 & 176,292 & 149,060 \\
\hline Auton. históricas & 1363,06 & 875,78 & 1398,08 & 935,14 & 1330,88 & 904,08 & 1276,96 & 933,03 \\
\hline$\overline{\text { Canarias }}$ & 50,495 & 69,402 & 50,495 & 69,402 & 58,381 & 58,381 & 56,476 & 56,476 \\
\hline C. Mancha & 69,402 & 55,356 & 69,402 & 55,356 & 71,349 & 58,076 & 67,591 & 57,587 \\
\hline Murcia & 0 & 0 & 0 & 0 & 55,529 & 53,089 & 48,468 & 46,654 \\
\hline Aragón & 59,156 & 45,394 & 59,156 & 45,394 & 62,665 & 54,868 & 65,355 & 56,717 \\
\hline Baleares & 32,765 & 28,256 & 32,765 & 28,256 & 32,765 & 28,256 & 48,352 & 42,952 \\
\hline Outras autonomías & 231,81 & 202,4 & 231,81 & 202,4 & 300,68 & 256,67 & 306,24 & 264,37 \\
\hline Total & 1594,87 & 1078,18 & 1629,89 & 1137,54 & 1631,56 & 1160,75 & 1583,20 & 1197,4 \\
\hline \multirow[t]{2}{*}{ RTV de FORTA } & \multicolumn{2}{|c|}{2011} & \multicolumn{2}{|c|}{2012} & \multicolumn{2}{|c|}{2013} & \multicolumn{2}{|c|}{2014} \\
\hline & Orzam. & Subv. & Orzam. & Subv. & Orzam. & Subv. & Orzam. & Subv. \\
\hline Andalucía & 232,433 & 166,887 & 219,661 & 152,562 & 185,51 & 160 & 191,2 & 162,7 \\
\hline Cataluña & 367,898 & 241,390 & 310,248 & 202,475 & 378,55 & 260,77 & 293,05 & 226,6 \\
\hline Madrid & 147,114 & 105,364 & 147,114 & 105,364 & 99,15 & 84,15 & 85,37 & 74,87 \\
\hline$\overline{\text { Valencia }}$ & 165,644 & 124,110 & 138,003 & 99,246 & 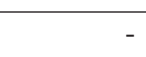 & - & - & \\
\hline Galicia & 121,550 & 101,147 & 117,164 & 99,147 & 107,9 & 94,07 & 103,6 & 90,32 \\
\hline P. Vasco & 171,654 & 140,762 & 167,106 & 130,964 & 175,15 & 139,01 & 135 & 112,13 \\
\hline Auton. históricas & 1206,29 & 879,66 & 1099,28 & 789,75 & 946,26 & 738 & 808,2 & 666,62 \\
\hline Canarias & 37,720 & 37,720 & 37 & 37 & 33,37 & 33,37 & 33,9 & 33,9 \\
\hline C. Mancha & 61,405 & 50,009 & 50,9 & 40,7 & 46,39 & 38,75 & 43,5 & 36,7 \\
\hline Murcia & 32,504 & 30,109 & - & - & - & - & - & - \\
\hline Aragón & 62,392 & 54,344 & 54,6 & 48 & 46,61 & 42,40 & 46,9 & 43 \\
\hline Baleares & 48,352 & 42,952 & 50,7 & 42,7 & 36,70 & 34 & 34 & 32,05 \\
\hline Asturias & & & 37,9 & 29,9 & 23,07 & 20,10 & 23,07 & 20,1 \\
\hline Estremadura & 32,22 & 31,05 & 27,3 & 26,6 & 24,8 & 23 & 24,8 & 23 \\
\hline Outras autonomías & 294,59 & 250,18 & 258,4 & 224,9 & 211 & 191,62 & 206,17 & 188,75 \\
\hline Total & 1501 & 1130 & 1357,4 & 1014,65 & 1157,2 & 929,62 & 1014,37 & 855,37 \\
\hline
\end{tabular}

Fonte: elaboración propia (cifras en millóns de euros) a partir dos orzamentos das RTVP autonómicas. 
Entre 2007 e 2014 os orzamentos das radiotelevisións autonómicas baixan un 36 \%, de 1594 a 1014 millóns. Neste período, a subvención directa das autonomías redúcese un $20 \%$, de 1078 a 855 millóns de euros. Os ingresos por publicidade nese período caen un $64 \%$ polo descenso da audiencia e a concentración do duopolio da televisión privada. Así, os aprovisionamentos das RTV autonómicas públicas baixan un 52 \%, de 586 a 278 millóns, e a contratación de servizos exteriores descende un 27 \% de 340 a 247 millóns de euros, entre 2007 e 2014. Ese impacto repercute negativamente na produción audiovisual privada, tamén na realizada en Galicia. A perda de recursos da CRTVG dana todo o audiovisual galego.

Cadro 17. Produción audiovisual galega

\begin{tabular}{|c|c|c|c|c|c|c|c|c|c|c|}
\hline \multirow{2}{*}{$\frac{\text { Empresa }}{\text { Anos }}$} & \multicolumn{5}{|c|}{ Ingresos } & \multicolumn{5}{|c|}{ Resultados } \\
\hline & 2013 & 2012 & 2011 & 2008 & 2007 & 2013 & 2012 & 2011 & 2008 & 2007 \\
\hline Abano & 270 & 122 & 408 & 34 & - & 7 & 7 & 16 & -5 & \\
\hline$\overline{\text { Adivina }}$ & 505 & 977 & 529 & 620 & 1223 & 5 & 2 & 5 & -32 & 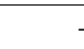 \\
\hline Arantia & 2324 & 2465 & 1713 & 533 & 888 & 89 & 359 & -130 & -564 & -158 \\
\hline Area 5.1 & 454 & 787 & 660 & 1022 & 784 & -68 & -26 & 1 & 2 & 137 \\
\hline Artemática & 431 & 177 & 140 & 128 & 29 & -4 & 0 & 0 & 25 & -27 \\
\hline Bambú & 18398 & 19377 & 22974 & 4393 & 68 & 26 & 136 & 194 & 10 & 12 \\
\hline Besteiro & 212 & 255 & 513 & 407 & 1027 & 13 & 12 & 45 & 14 & 384 \\
\hline Marcote & 904 & 808 & 796 & 1086 & 806 & 46 & 57 & 19 & 15 & 16 \\
\hline E. Cine & 32 & 72 & 128 & 161 & 159 & -28 & -58 & -27 & -9 & -10 \\
\hline Congo & 606 & 721 & 718 & 1597 & 1044 & 24 & 41 & 45 & 175 & 34 \\
\hline CTV & 5045 & 5365 & 6262 & 6865 & 7859 & 53 & -257 & 109 & 450 & 453 \\
\hline Enxebre & 38 & 89 & 87 & 217 & 148 & 12 & 24 & -32 & -42 & -8 \\
\hline Faro & 1963 & 2836 & 2362 & 5719 & 5261 & -258 & 50 & 54 & 116 & 62 \\
\hline Faro Lérez & 22 & 100 & 33 & 839 & 819 & -60 & 48 & 15 & 35 & 86 \\
\hline Ficción & 1397 & 1229 & 1338 & 963 & 1179 & 95 & 51 & 133 & 32 & 39 \\
\hline Filmanova I & 20 & 616 & 327 & 510 & 267 & 21 & -1025 & 202 & -431 & -711 \\
\hline Filmanova S & 1 & 49 & 46 & 113 & 321 & -4 & -11 & -14 & -18 & 32 \\
\hline Filmanova & 18 & 224 & 523 & 3169 & 4076 & -225 & -597 & 148 & -460 & 40 \\
\hline FilmaxAn. & - & - & - & 688 & 6608 & - & - & - & -1286 & 574 \\
\hline Formato & 455 & 528 & 603 & 938 & 802 & 5 & 4 & 11 & 4 & 23 \\
\hline Interdix & 123 & 187 & 222 & 168 & 196 & 1 & -21 & 1 & -38 & -22 \\
\hline Ilux & 639 & 290 & 185 & - & - & 5 & 1 & 3 & - & - \\
\hline Interacción & - & 109 & 272 & 363 & 447 & - & -1 & 5 & 8 & 9 \\
\hline Loroestudio & - & - & - & 362,67 & 447,31 & - & - & - & 7,62 & 9,44 \\
\hline Lugopress & - & 147 & 82 & 118 & 358 & - & -165 & -121 & 4 & 6 \\
\hline Milou & 485 & 2763 & 153 & 6391 & 1026 & 2 & 12 & 5 & -1057 & 4 \\
\hline Mondotropo & 191 & 450 & 382 & 772 & 514 & 4 & 5 & 0 & 0 & 0 \\
\hline Nos & 140 & 74 & 125 & 36 & 195 & -13 & 3 & 22 & -8 & 23 \\
\hline Raio Verde & 98 & 124 & 226 & 156 & 175 & 1 & 3 & 3 & -8 & 3 \\
\hline Openor & 354 & 343 & 384 & 275 & 238 & 13 & -32 & -62 & 66 & 30 \\
\hline Otiiplanet & 164 & 59 & 104 & 135 & - & 2 & 17 & -11 & 4 & 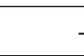 \\
\hline Pequerrecho & 49 & 57 & 16 & - & - & 0 & 0 & 2 & - & . \\
\hline Perro Verde & - & - & 62 & 174 & 138 & - & - & 1 & -29 & 4 \\
\hline
\end{tabular}




\begin{tabular}{lrrrrrrrrrr} 
Empresa & \multicolumn{9}{c}{ Ingresos } & \multicolumn{7}{c}{ Resultados } \\
\hline Anos & $\mathbf{2 0 1 3}$ & $\mathbf{2 0 1 2}$ & $\mathbf{2 0 1 1}$ & $\mathbf{2 0 0 8}$ & $\mathbf{2 0 0 7}$ & $\mathbf{2 0 1 3}$ & $\mathbf{2 0 1 2}$ & $\mathbf{2 0 1 1}$ & $\mathbf{2 0 0 8}$ & $\mathbf{2 0 0 7}$ \\
\hline Pórtico & - & 1493 & 1474 & 2549 & 2351 & - & 30 & 6 & 158 & 223 \\
\hline P. Vigo & 91 & 106 & 179 & 161 & 147 & -71 & -123 & -82 & -148 & -127 \\
\hline Saga & - & - & 338 & 324 & 333 & - & - & 0 & 0 & 0 \\
\hline Spica & 1810 & 3252 & 2342 & 3837 & 6407 & 50 & 71 & -11 & 69 & 282 \\
\hline Studio XXI & 599 & 644 & 992 & 1071 & 1077 & -48 & -24 & 105 & 145 & 99 \\
\hline Telecable C & 732 & 862 & 1728 & 2382 & 2276 & -285 & -202 & -128 & 58 & 5 \\
\hline Telemiño & 494 & 471 & 828 & 855 & 636 & 2 & -111 & 104 & 68 & 66 \\
\hline TV Siete & 930 & 653 & 685 & 1659 & 2043 & -30 & -112 & -38 & 113 & 126 \\
\hline Voz Audiov. & 3964 & 5396 & 6268 & 7882 & 10839 & 805 & 738 & 512 & 241 & 507 \\
\hline Canal Voz & 3964 & 1850 & 1606 & 1537 & 1644 & 62 & 111 & 95 & 182 & 195 \\
\hline Xamalú & 442 & 246 & 265 & 238 & 201 & 8 & 4 & 4 & 4 & 4 \\
\hline Cinemar & 175 & 197 & 265 & 112 & 15 & -88 & 22 & -28 & -9 & -73 \\
\hline Continental & - & - & - & 6771 & 6513 & - & - & - & 206 & 57 \\
\hline Sodinor & - & 485 & 671 & 848 & 1414 & - & -86 & -56 & 6 & 65 \\
\hline Vaca & 415 & 399 & 1179 & 148 & 406 & 48 & 80 & 876 & -27 & -35 \\
\hline Vía Láctea & 499 & 440 & 169 & 428 & 374 & 15 & 24 & 24 & 9 & 5 \\
\hline Zenit & 691 & 1235 & 1142 & 968 & 4776 & 10 & -51 & 1 & 46 & $-673,4$ \\
\hline ZircoZine & 830 & 1069 & 932 & 84 & - & 12 & -18 & 8 & -3 & -1 \\
\hline & & & & & & & & &
\end{tabular}

Fonte: datos de SABI (que recolle do Rexistro Mercantil). As cifras están en miles de euros e as de débeda en porcentaxes.

Os ingresos da produción audiovisual galega, tomando como referencia a relación das principais produtoras, sofren un impacto negativo superior ao $35 \%$ entre 2008 e 2013. E os ingresos desas empresas aínda caen moito máis nese período, ata un $85 \%$. Os efectos, como é obvio, repercuten no emprego, que sofre tamén un descenso do $25 \%$, e no incremento da débeda das empresas de produción audiovisual.

Cadro 18. Emprego e apancamento do audiovisual galego

\begin{tabular}{lrrrrrrrrrr} 
Empresa & \multicolumn{1}{c}{ Empregados declarados no R. Mercantil } & \multicolumn{5}{c}{ Porcentaxe de endebedamento } \\
\hline Anos & $\mathbf{2 0 1 3}$ & $\mathbf{2 0 1 2}$ & $\mathbf{2 0 1 1}$ & $\mathbf{2 0 0 8}$ & $\mathbf{2 0 0 7}$ & $\mathbf{2 0 1 3}$ & $\mathbf{2 0 1 2}$ & $\mathbf{2 0 1 1}$ & $\mathbf{2 0 0 8}$ & $\mathbf{2 0 0 7}$ \\
\hline Abano & 1 & 1 & 1 & 1 & - & 80,88 & 67,50 & 76,17 & 119,43 & - \\
\hline Adivina & - & - & - & - & - & 63,88 & 73,76 & 68,52 & 73,64 & 71,83 \\
\hline Arantia & 13 & 13 & 12 & 9 & 7 & 45,26 & 50,11 & 48,66 & 26,23 & 81,04 \\
\hline Area 5.1 & 9 & 9 & 11 & 15 & 21 & 32,69 & 35,47 & 29,95 & 39,43 & 44,49 \\
\hline Artemática & 2 & - & 3 & 3 & - & 78,99 & 80,04 & 76,38 & 95,91 & 87,55 \\
\hline Bambú & 140 & 116 & 185 & 43 & - & 93 & 94,76 & 97,67 & 97,10 & 43,34 \\
\hline Besteiro & 1 & 1 & 1 & 2 & 1 & 52,34 & 41,53 & 36,77 & 23,11 & 29,44 \\
\hline Marcote & 12 & 10 & 9 & 10 & 16 & 39,35 & 40,25 & 40,32 & 44,71 & 24,74 \\
\hline E. Cine & 1 & 2 & 1 & 2 & 6 & 155,11 & 138,28 & 105,11 & 171,95 & 164,96 \\
\hline Congo & 10 & 5 & 5 & 7 & 6 & 55,57 & 44,20 & 59,20 & 62,33 & 75,41 \\
\hline CTV & 101 & 101 & 89 & 75 & - & 48,23 & 45,98 & 47,15 & 47,36 & 55,87 \\
\hline Enxebre & 1 & 3 & 3 & 3 & 5 & 52,98 & 58,09 & 71,25 & 60,38 & 46,21 \\
\hline Faro & 43 & 55 & 44 & 98 & - & 72,89 & 69,09 & 71,73 & 81,43 & 86,29 \\
\hline
\end{tabular}




\begin{tabular}{|c|c|c|c|c|c|c|c|c|c|c|}
\hline \multirow{2}{*}{$\frac{\text { Empresa }}{\text { Anos }}$} & \multicolumn{5}{|c|}{ Empregados declarados no R. Mercantil } & \multicolumn{5}{|c|}{ Porcentaxe de endebedamento } \\
\hline & 2013 & 2012 & 2011 & 2008 & 2007 & 2013 & 2012 & 2011 & 2008 & 2007 \\
\hline Faro Lérez & 1 & 1 & 1 & 22 & - & 49,19 & 31,40 & 43,76 & 64,20 & 73,09 \\
\hline Ficción & 28 & 29 & 42 & 31 & 22 & 67,99 & 72,43 & 81,05 & 80,78 & 74,74 \\
\hline Filmanova I & 1 & 15 & 1 & - & - & 19,01 & 43,70 & 23,16 & 16,93 & 6,43 \\
\hline Filmanova S & 1 & 1 & 1 & - & - & 147,16 & 105,82 & 78,96 & 69,40 & 57,35 \\
\hline Filmanova & 3 & 3 & 13 & 31 & 49 & 101,88 & 90,00 & 63,24 & 91,74 & 82,81 \\
\hline FilmaxAn. & - & - & - & 4 & 13 & - & - & - & 70,10 & 85,45 \\
\hline Formato & 6 & 9 & 7 & 6 & 7 & 38,48 & 53,73 & 50,33 & 74,51 & 77,41 \\
\hline Interdix & 2 & 1 & 1 & 2 & 2 & 71,12 & 70,24 & 68,19 & 72,26 & 172,98 \\
\hline Ilux & 6 & 6 & 6 & - & - & 87,37 & 86,62 & 26,84 & - & \\
\hline Interacción & - & 6 & 7 & 11 & 10 & - & 59,64 & 66,32 & 71,51 & 71,16 \\
\hline Loroestudio & - & - & - & 4 & 3 & - & - & - & 61,85 & 10,84 \\
\hline Lugopress & - & 5 & 6 & 4 & 4 & - & 110,38 & 77,06 & 6,36 & 10,84 \\
\hline Milou & 1 & 2 & 2 & & & 19,69 & 25,39 & 34,87 & 44,32 & 6,85 \\
\hline Mondotropo & 3 & 4 & 5 & 4 & 4 & 90,60 & 96,04 & 98,39 & 98,03 & 98,03 \\
\hline Nos & 2 & 2 & 3 & - & - & 64,80 & 78,62 & 78,84 & 65,74 & 75,45 \\
\hline Raio Verde & 5 & 5 & - & 2 & 3 & 74,55 & 78,37 & 82,37 & 98,42 & 85,67 \\
\hline Openor & 2 & 2 & 3 & 1 & 1 & 135,63 & 132,73 & 23,64 & 47,09 & 29,75 \\
\hline Otiiplanet & 3 & 3 & 3 & 2 & - & 33,94 & 14,70 & 18,72 & 86,98 & 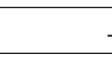 \\
\hline Pequerrecho & - & - & - & - & - & 78,87 & 77,05 & 55,28 & - & \\
\hline Perro Verde & - & - & 1 & 1 & 3 & - & - & 68,03 & 100,38 & 99,66 \\
\hline Pórtico & - & 31 & 31 & 46 & 47 & - & 43,41 & 48,09 & 60,08 & 66,76 \\
\hline P. Vigo & 4 & 5 & 6 & 3 & 4 & 120,20 & 109,96 & 92,88 & 219,65 & 198,95 \\
\hline Saga & - & - & 5 & 7 & 7 & - & - & 88,35 & 89,36 & 83,13 \\
\hline Spica & 21 & 24 & 25 & 25 & 24 & 30,23 & 48,79 & 48,73 & 56,64 & 75,33 \\
\hline Studio XXI & 13 & 13 & 15 & 24 & 24 & 25,41 & 16,48 & 17,48 & 12,89 & 15,85 \\
\hline Telecable C & 22 & 68 & 64 & 58 & 54 & 146,50 & 116,37 & 103,30 & 63,55 & 59,93 \\
\hline Telemiño & 16 & 24 & 25 & 25 & 19 & 20,48 & 19,19 & 26,09 & 46,93 & 52,91 \\
\hline TV Siete & 14 & 9 & 8 & 28 & 46 & 17,70 & 16,71 & 8,49 & 33,86 & 40,69 \\
\hline Voz Audiov. & 70 & 70 & 84 & 92 & 109 & 15,53 & 12,60 & 12,38 & 24,46 & 41,89 \\
\hline Canal Voz & 11 & 10 & 17 & 16 & 14 & 54,75 & 55,13 & 66,82 & 35,19 & 66,52 \\
\hline Xamalú & - & 2 & 1 & - & - & 36,17 & 61,40 & 62,60 & 94,73 & 79,06 \\
\hline Cinemar & 5 & 4 & 3 & - & - & 67,81 & 56,36 & 56,80 & 46,88 & 80,53 \\
\hline Continental & - & - & - & 35 & 40 & - & - & - & 94,72 & 95,97 \\
\hline Sodinor & - & 6 & 8 & 8 & - & - & 72,01 & 63,90 & 62,48 & 68,69 \\
\hline Vaca & 3 & 4 & 4 & 25 & 3 & 56,89 & 52,68 & 50,35 & 90,43 & 67,85 \\
\hline Vía Láctea & 2 & 3 & 9 & - & - & 69,98 & 62,35 & 92,27 & 87,92 & 90,41 \\
\hline Zenit & 9 & 18 & 11 & 10 & 12 & 80,93 & 84,65 & 79,55 & 81,84 & 87,62 \\
\hline ZircoZine & 3 & 3 & 1 & - & - & 41,94 & 56,00 & 46,88 & 100,30 & 38,77 \\
\hline
\end{tabular}

Fonte: elaboración a partir dos datos que as empresas entregan no Rexistro Mercantil procesados por SABI.

Unha tendencia aínda máis sobranceira rexístrase na actividade económica das principais editoriais galegas, que, no seu conxunto e nese mesmo período de 2008-2013, perden un $43 \%$ do seu negocio. Tamén destaca a perda 
de emprego e o seu incremento no nivel de apancamento, segundo os datos rexistrados polas editoras (todas elas pequenas e microempresas). Para reflectir a tendencia xeral, coma no caso das produtoras, recolléronse os datos dunha mostra diversa -aínda que non completa- de empresas dos sectores da produción de libros e audiovisual.

Cadro 19. Ingresos e resultados das editoriais galegas

\begin{tabular}{|c|c|c|c|c|c|c|c|c|c|c|}
\hline \multirow{2}{*}{$\frac{\text { Empresa }}{\text { Anos }}$} & \multicolumn{5}{|c|}{ Ingresos das contas segundo R. Mercantil } & \multicolumn{5}{|c|}{ Resultados das contas segundo R. Mercantil } \\
\hline & 2013 & 2012 & 2011 & 2008 & 2007 & 2013 & 2012 & 2011 & 2008 & 2007 \\
\hline Editora 2.0* & 155 & 144 & 296 & 340 & - & 2 & 6 & 5 & -10 & - \\
\hline Alvarellos & - & - & - & 19 & - & - & - & - & 1 & - \\
\hline Andavira & 186 & 193 & 236 & 252 & 242 & 0 & 1 & 14 & 2 & 3 \\
\hline Baía & 349 & 407 & 464 & 509 & 421 & 0 & 1 & 4 & 6 & 5 \\
\hline Biblos & 155 & 142 & 130 & 217 & 207 & -12 & -15 & -12 & -1 & -8 \\
\hline Difusora & 4 & 16 & 44 & 131 & 159 & 1 & 1 & 4 & 28 & 2 \\
\hline Linteo & 70 & 2558 & 1543 & 51 & 202 & -15 & -16 & -47 & -46 & -4 \\
\hline Do Castro & - & - & - & 95 & 170 & 0 & 0 & 0 & -173 & -165 \\
\hline Do Cumio & 364 & 317 & 439 & 554 & 369 & 9 & -59 & 21 & 36 & 10 \\
\hline Laiovento & 29 & 50 & 89 & 91 & 94 & -30 & -21 & -7 & -9 & 1 \\
\hline Lea & 2 & 12 & 18 & 52 & 66 & -14 & -16 & -16 & 1 & 3 \\
\hline Lóstrego & 7 & 16 & 17 & - & - & -19 & 6 & 4 & - & - \\
\hline Nigra Trea & 121 & 160 & 232 & 393 & 339 & -5 & -5 & -4 & 9 & 12 \\
\hline Obradoiro & 500 & 482 & 446 & 512 & 427 & 1 & 1 & 0 & 1 & 1 \\
\hline Danú & - & - & 150 & 23 & 40 & - & - & 2 & 0 & 0 \\
\hline Everest Gal. & 96 & 88 & 114 & 165 & 162 & -48 & -34 & -32 & 1 & 2 \\
\hline Galaxia & 1403 & 1505 & 1919 & 2164 & 1941 & -35 & -123 & 9 & 23 & 23 \\
\hline Galicia Media & 586 & 797 & 817 & 1197 & 2377 & -29 & 26 & 67 & 23 & 198 \\
\hline Netbiblo & - & 376 & 533 & 600 & 342 & - & 1 & 1 & 1 & 0 \\
\hline Novosvieiros & 60 & 169 & 451 & 293 & 620 & -69 & -39 & -1 & -84 & 12 \\
\hline Primerapersona** & & & & 35 & 59 & & & & -33 & -18 \\
\hline Toxosoutos & 263 & 315 & 369 & 531 & 494 & -29 & -3 & -5 & 2 & 1 \\
\hline Tris Tram & 1 & 2 & 5 & 19 & 20 & 0 & 0 & 0 & -2 & 0 \\
\hline Xerais & 1796 & 1807 & 2021 & 2921 & 2679 & -304 & -187 & -362 & -155 & -87 \\
\hline El Patito*** & - & - & 149 & 105 & - & - & - & 0 & -27 & - \\
\hline Galinova & 1070 & 1281 & 1376 & 1444 & 1212 & 448 & 512 & 493 & 622 & 475 \\
\hline Hércules & 1284 & 1328 & 2232 & 2875 & 3350 & -264 & -367 & 2 & 72 & 251 \\
\hline Ideaspropias & 574 & 718 & 1148 & 1633 & 1259 & 13 & 32 & 44 & 192 & 180 \\
\hline Kalandraka & 2000 & 1823 & 2084 & 2157 & 1884 & 65 & 25 & 34 & 22 & 42 \\
\hline Nova Galicia & 594 & 507 & 643 & 822 & 1099 & -7 & 3 & 1 & 31 & 32 \\
\hline QQO & 776 & 596 & 959 & 1100 & 691 & 60 & 8 & 51 & 32 & 38 \\
\hline Ouvirmos & 61 & 105 & 104 & 195 & 132 & 5 & 9 & 1 & 31 & 1 \\
\hline Sotelo & 99 & 117 & 106 & 308 & 350 & 4 & -7 & -13 & 8 & 14 \\
\hline Teófilo & 346 & 678 & 631 & 962 & 821 & -206 & 5 & 6 & 9 & 9 \\
\hline TresCtres $* * * *$ & - & - & - & 385 & 990 & - & - & - & 3 & 38 \\
\hline Xerme & 772 & 949 & 721 & 861 & 781 & 89 & -53 & 4 & -792 & 296 \\
\hline
\end{tabular}

Fonte: elaboración propia con cifras das contas presentadas no Rexistro Mercantil e procesadas por SABI. * Reverso Comunicación Cultura e Lingua SL ** Monllor y Gey editores SL *** Fausto Deseño Asociados **** 314 Euroediciones SL. 
A actividade destas empresas está directamente relacionada co investimento e gasto cultural. En 2013, segundo a enquisa de orzamentos familiares realizada polo Instituto Nacional de Estadística, o gasto cultural en España ascendeu a 12 261,7 millóns de euros, un 2,5 \% do destinado a bens e servizos en xeral. Os equipamentos audiovisuais e de Internet (43,9\%) representan o maior volume, seguido dos servizos culturais $(33,6 \%)$ e os libros e publicacións periódicas (15,8 \%). Galicia está por baixo da media de España en gasto cultural (arredor de 600 euros ao ano por fogar). Segundo a enquisa de hábitos e prácticas culturais, os máis frecuentes son escoitar música, ler e ir ao cine, con taxas do 84,4 \%, 58,7 \% e 49,1\%, respectivamente.

A produción editorial española aumentou en 2014 un 1,9 por cento con respecto ao ano anterior, ao pasar de 89130 en 2013 a 90802 libros. 0 aumento foi maior (un 3,7 \%) na publicación de libros en papel (68 378 en 2014 fronte a 65 942) mentres a edición noutros soportes (entre eles o dixital) descendeu nun 3,3 \% (22 424 títulos fronte a 23188 en 2013). A edición dixital representa o 25 \% da publicación editorial española, cun volume de actividade económica por riba dos 75 millóns de euros, aínda que de momento a súa facturación non pasa do $5 \%$ da actividade económica total do sector.

A edición en galego representa o 2,1 \% do total; en éuscaro, o 2 \%; en valenciano, o 1,4 \%; en catalán, o 9,9 \%, e en castelán, o 84,5\%. Durante 2014 editáronse en Galicia 2877 libros, nas provincias da Coruña (1421), Pontevedra (1321), Ourense (78) e Lugo (57). Esta última provincia foi a única que rexistrou un descenso $(-49,1 \%)$ no número de publicacións. O sector editorial en Galicia, como se aprecia nos seus resultados e apancamento, é feble e inestable.

Cadro 20. Emprego e endebedamento das editoriais galegas

\begin{tabular}{|c|c|c|c|c|c|c|c|c|c|c|}
\hline \multirow{2}{*}{$\frac{\text { Empresa }}{\text { Anos }}$} & \multicolumn{5}{|c|}{ Emprego segundo datos do Rexistro } & \multicolumn{5}{|c|}{ Mercantil Porcentaxes de endebedamento } \\
\hline & 2013 & 2012 & 2011 & 2008 & 2007 & 2013 & 2012 & 2011 & 2008 & 2007 \\
\hline Editora 2.0 & 2 & 4 & 8 & 10 & - & 92,53 & 95,27 & 99,86 & 100,22 & - \\
\hline Alvarellos & - & - & - & 2 & - & - & - & - & 7,88 & 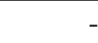 \\
\hline Andavira & 1 & 1 & 1 & 2 & - & 77,77 & 79,02 & 77,28 & 84,92 & 87,22 \\
\hline Baía & - & 3 & 3 & - & - & 91,24 & 83,32 & 81,44 & 85,39 & 84,96 \\
\hline Biblos & 3 & 2 & 2 & 2 & 2 & 41,60 & 31,03 & 30,87 & 29,81 & 27,85 \\
\hline$\overline{\text { Difusora }}$ & 1 & - & - & 1 & 2 & 16,30 & 14,25 & 29,29 & 63,23 & 93,49 \\
\hline Linteo & 3 & 2 & 2 & 2 & 1 & 0,22 & 3,58 & 0,26 & 1,52 & 65,78 \\
\hline Do Castro & - & - & - & 5 & 6 & 251,43 & 240,60 & 240,47 & 233,08 & 84,96 \\
\hline Do Cumio & 3 & 5 & 6 & 7 & 4 & 67,85 & 73,86 & 69,03 & 77,64 & 82,89 \\
\hline Laiovento & 1 & 1 & 1 & 1 & 1 & 57,70 & 28,76 & 15,91 & 77,52 & 72,55 \\
\hline Lea & - & 1 & 1 & 2 & 2 & 184,03 & 139,37 & 94,78 & 28,18 & 34,65 \\
\hline Lóstrego & - & - & - & - & - & 5,73 & 5,94 & 8,33 & - & \\
\hline Nigra Trea & 2 & 2 & 4 & 2 & 2 & 94,36 & 92,27 & 89,84 & 50,01 & 52,19 \\
\hline Obradoiro & 6 & 5 & 4 & 4 & 4 & 56,02 & 49,74 & 52,28 & 61,19 & 46,23 \\
\hline Danú & - & - & - & - & - & - & - & 72,98 & 71,80 & 65,68 \\
\hline Everest Gal. & 2 & 2 & 3 & 3 & 2 & 116,64 & 107,66 & 106,27 & 70,63 & 80,19 \\
\hline Galaxia & 16 & 19 & 19 & 17 & 18 & 49,10 & 39,62 & 38,87 & 51,40 & 52,65 \\
\hline Galicia Media & 4 & 3 & 4 & 3 & 4 & 12,18 & 21,05 & 14,02 & 32,96 & 39,86 \\
\hline Netbiblo & - & 1 & 1 & 2 & 2 & - & 97,13 & 97,84 & 97,80 & 97,84 \\
\hline Novosvieiros & 2 & - & 8 & 8 & 8 & 180,77 & 134,48 & 118,50 & 105,06 & 91,98 \\
\hline Primerapersona & - & - & - & 1 & 1 & - & - & - & 89,98 & 93,69 \\
\hline Toxosoutos & 4 & 3 & 4 & 5 & 5 & 100,09 & 95,25 & 94,96 & 94,38 & 94,90 \\
\hline
\end{tabular}




\begin{tabular}{lrrrrrrrrrr} 
Empresa & \multicolumn{1}{c}{ Emprego segundo datos do Rexistro } & \multicolumn{3}{c}{ Mercantil Porcentaxes de endebedamento } \\
\hline Anos & $\mathbf{2 0 1 3}$ & $\mathbf{2 0 1 2}$ & $\mathbf{2 0 1 1}$ & $\mathbf{2 0 0 8}$ & $\mathbf{2 0 0 7}$ & $\mathbf{2 0 1 3}$ & $\mathbf{2 0 1 2}$ & $\mathbf{2 0 1 1}$ & $\mathbf{2 0 0 8}$ & $\mathbf{2 0 0 7}$ \\
\hline Tris Tram & - & - & - & - & 1 & 84,22 & 83,87 & 83,40 & 77,79 & 69,60 \\
\hline Xerais & 14 & 14 & 14 & 16 & 14 & 91,40 & 88,01 & 94,33 & 58,58 & 50,29 \\
\hline El Patito & - & - & 2 & 3 & - & - & - & 68,82 & 107,58 & - \\
\hline Galinova & 4 & 3 & 3 & 4 & 3 & 12,62 & 17,32 & 17,87 & 21,42 & 24,26 \\
\hline Hércules & 22 & 27 & 29 & 36 & 37 & 11,66 & 10,05 & 8,90 & 16 & 13,85 \\
\hline Ideaspropias & 11 & 13 & 17 & - & - & 53,00 & 55,25 & 64,17 & 67,11 & 66,83 \\
\hline Kalandraka & 13 & 12 & 14 & 16 & 14 & 60,11 & 65,14 & 71,01 & 65,50 & 70,19 \\
\hline Nova Galicia & 6 & 7 & 12 & 13 & - & 35,11 & 28,63 & 31,32 & 24,88 & 30,65 \\
\hline OQO & 8 & 9 & 9 & 5 & 5 & 57,62 & 66,73 & 65,18 & 88,17 & 89,31 \\
\hline Ouvirmos & 1 & 2 & 2 & 2 & & 58,20 & 64,99 & 73,44 & 67,45 & 89,54 \\
\hline Sotelo & 2 & 2 & 2 & 2 & 2 & 98,08 & 99,04 & 97,82 & 97,33 & 98,49 \\
\hline Teófilo & 4 & 8 & 6 & 9 & 9 & 150,97 & 69,55 & 78,30 & 86,88 & 82,19 \\
\hline TresCtres & - & - & - & 3 & 1 & - & - & - & 48,62 & 42,43 \\
\hline Xerme & - & - & - & - & - & 83,67 & 113,44 & 98,63 & 156,31 & 67,36 \\
\hline
\end{tabular}

Fonte: elaboración propia con datos das contas do Rexistro Mercantil procesadas por SABI de Informa.es.

\section{CONCLUSIÓN}

Concluímos con intención futurista, pero non agoireira. A transición dixital avanza de forma incuestionable. Os medios de comunicación e as industrias culturais tradicionais teñen por diante unha década de retos inevitables. As proxeccións de cambio nos consumos dos produtos en papel, dos sistemas de difusión e modelos de negocio tradicionais son bastantes contundentes. A fragmentación das audiencias tradicionais e a obsolescencia das vellas tecnoloxías (posibilidade de desaparición da televisión dixital terrestre en 2025-30) poñen ás organizacións audiovisuais na carreira de dez anos para adaptarse á supervivencia en Internet. Iso é o que aventa o informe da nova Carta Real da BBC para o seu período de 2017-2027.

Esa supervivencia é máis vital para as radiotelevisións públicas porque as súas actuais estruturais están máis anquilosadas, a gobernanza máis burocratizada, o modelo de financiamento máis deteriorado e as políticas de regulamentación máis desorientadas. Porén, os medios de comunicación e servizos audiovisuais, tanto públicos como privados, son elementos esenciais de interacción social, simbólica e económica dos que as sociedades modernas non poden claudicar. Por iso, as políticas institucionais europeas, estatais e rexionais deben volver á reflexión dura sobre a importancia do seu valor estratéxico para os próximos anos.

$\mathrm{O}$ dilema do cambio nas organizacións tradicionais seguramente é o reto máis transcendente. Saber como, canto e cando cambiar é o gran dilema. Pero é un dilema que ten que ser dinámico e non estático. É o dilema da innovación e do talento da xestión. As organizacións tradicionais teñen grandes dificultades para acoplarse á innovación disruptiva (non poden abandonar os vellos modelos de negocio e adaptar os novos porque estes aínda non son rendibles e aqueles xa non producen o suficiente para a sustentabilidade) pero non poden abdicar da innovación adaptativa.

Mirando o noso territorio máis próximo, ese reto institucional e innovador aínda se presenta máis transcendente se observamos as perspectivas económicas e estratéxicas das distintas organizacións. A nova década dixital é aínda máis transcendente para a nosa cultura e identidade galegas. Trátase, pois, de poñer conciencia e visión de como pode ser e como debería ser a comunicación e as industrias culturais da Galicia de 2025. Un compromiso que abrangue as propias organizacións, as políticas institucionais e, tamén, a nosa sociedade no seu conxunto. 


\section{RECOÑECEMENTO DA INVESTIGACIÓN}

Os resultados deste artigo forman parte das actividades de investigación promovidas a través da Rede XESCOM (R2014/026 XESCOM), aprobada pola Consellería de Cultura, Educación e Ordenación Universitaria da Xunta de Galicia; das tarefas exploratorias do proxecto do Programa estatal de Fomento da Investigación Científica e Técnica de Excelencia, subprograma estatal de Xeración de Coñecemento do Ministerio de Economía e Competitividade de España sobre «Indicadores de gobernanza, financiamento, rendición de contas, innovación, calidade e servizo público das RTV europeas aplicables a España no contexto dixital» (Referencia CSO2015-66543-P); e do Programa Prometeo da Secretaría Nacional de Educación Superior, Ciencia, Tecnoloxía e Innovación (SENESCYT) de Ecuador, desenvolvido na Universidad Técnica Particular de Loja (UTPL) e na Pontificia Universidad Católica de Ibarra (PUCESI). 


\section{REFERENCIAS BIBLIOGRÁFICAS}

AETHA (2014): «Future use of the 470-694 MHz band. Report for Abertis, Arqiva, BBC, BNE, EBU and TDF», 31 de outubro. AlLE, Verna / Oliver SchwaBer (2011): Value Networks and the true nature of collaboration, ValuetNet Works, ed. (http://www. valuenetworksandcollaboration.com/).

BAuWEns, Michel (2015): Sauver le monde. Vers une économie post-capitaliste avec le peer-to-peer, París, Éditions Les Liens qui Libèrent.

Benghozı, Paul-Jean (2011): Télévision, l'ère du numérique, París, La Documentation Française.

Boyd, Danah M. / Nicole B. Eluıson (2007): «Social Network Sites: Definition, History, and Scholarship», Journal of ComputerMediated Communicaton, 13(1), 210-230.

Burnley, Richard (2015): Public Fundic Principles for Service Media, EBU (http://www3.ebu.ch/home).

BustamAnte, Enrique (1999): La television económica. Financiación, estrategias y mercados, Barcelona, Gedisa.

CALmard, Pierre (2015): L'homme à venir. Comment le numérique va nous transformer, París, Éditions Télémaque.

CAmpos-Freire, Francisco (2012): «Modelos de financiación de las televisiones públicas autonómicas», en Juan Carlos Miguel de Bustos / Miguel Ángel Casado del Río (coords.), Televisiones autonómicas. Evolución y crisis del modelo público de proximidad, Barcelona, Gedisa.

CAmpos Freire, Francisco. (coord.) (2011): El nuevo escenario mediático, Zamora / Sevilla, Comunicación Social.

CASTELLS, Manuel (2009): Comunicación y poder, Madrid, Alianza Editorial.

CELAYA, Javier et al. (2014): «Nuevos modelos de negocio en la era digital». Estudo elaborado por Dosdoce.com para CEDRO con motivo do lanzamento da plataforma Conlicencia.com (www.dosdoce.com).

Christensen, Clayton M. (1997): The Innovator's Dilemma: When New Technologies Cause Great Firms to Fail, Harvard Business Press.

Christensen, Clayton M. (2014): «Disruptive Innovation», en Mads Soegaard / Rikke Friis Dam (eds.), The Encyclopedia of Human-Computer Interaction, 2nd Ed., Aarhus, Denmark, The Interaction Design Foundation (https://www.interactiondesign.org/encyclopedia/disruptive innovation.html).

Christensen, Clayton M. / Joseph L. Bower (1995): "Disruptive Technologies: Catching the Wave», en Harvard Business Review (https://hbr.org/1995/01/disruptive-technologies-catching-the-wave).

CNMC (2014): «Informe económico de las telecomunicaciones y del sector audiovisual 2014» (www.cnmc.es).

DAvenport, Thomas H. / John C. Beck (2002): La economía de la atención: el nuevo valor de los negocios, Barcelona, Paidós.

DCMS (2015): «BBC Charter Review Public Consultation 16 july-8 october 2015», Department for Culture, Media and Sport (https://www.gov.uk/government/organisations/department-for-culture-media-sport)

DigitAl FutURE (2014): The 2014 Digital Future Report. Surveying The Digital Future. Year Twelve, Annenberg School Center for the Digital Future, University of Southern California. Jeffrey I. Cole director World Internet Project, Michael Suman, Phoebe.

DiRECTIVAS UE: 89/552/CEE de la TV Sin Fronteras, 2007/65/CE de Servicios de Comunicación Audiovisual e 2010/13/UE de Medios Audiovisuales (www.europa.eu).

Donders, Karen (2011): Public service media and policy in Europe, Londres, Palgrave Macmillan.

Donders, Karen / Hallvard Moe (2011): «Exporting the Public Value Test: The Regulation of Public Broadcasters' New Media Services across Europe», Göteborg, Nordicom.

Doyle, Gillian (2012): «Economía audiovisual: los mercados audiovisuales en la Unión Europea», Quaderns del CAC, 38, vol. $\mathrm{XV}(1), 15-24$.

EBU (2012): «EBU Viewpoint PSM Funding», EBU-UER, European Broadcasting Union (EBU) (http://www3.ebu.ch/home).

ERICSON (2015): «TV and Media 2015. The empowered TV and Media consumer's influence» (http://www.ericsson.com/res/ docs/2015/consumerlab/ericsson-consumerlab-tv-media-2015.pdf).

Fernández Lombao, Tania / Francisco Campos FreiRe (2013): «La Responsabilidad Social Corporativa en las radiotelevisiones públicas en Europa», Cuadernos Info, Chile, 33, 145-157. DOI 107764/cdi. 33.530.

FINE, Charles H. (2000): El nuevo ciclo empresarial. Ventajas competitivas en la era de la velocidad, Barcelona, Paidós.

FLICHY, Pierre (1980): Les industries de l'imaginaire: pour une anályse économique des media, París, INA.

Fuchs, Christian (2014): "Medios sociales y esfera pública», Telos, 98, xuño-setembro.

GoyAnEs, Manuel (2013): «Estrategias y modelos de negocio: Aclaración de conceptos y terminología de la prensa en Internet», Estudios sobre el Mensaje Periodístico, 1, 419-431. 
Hallin, Daniel C. / Paolo Mancini (2008): Sistemas mediáticos comparados. Tres modelos de relación entre los medios de comunicación y la política, Barcelona, Editorial Hacer.

IOSIFIDIS, Petros (2010): «Servicio público de televisión en Europa», Infoamérica, Málaga (www.infoamerica.org/icr/n03-04/ iosifidis.pdf).

IoSIFIDIS, Petros (2011): «Growing pains? The transition to digital TV in Europe», European Journal of Communication, 26(1), 3-17.

Jenkins, Henry (2006): Convergence Culture: Where Old and New Media Collide, Nova York, New York University Press.

Jost, Françols (2011): «Place du produit télévisuel dans I'espace public et I'espace social», en J.-Ch. Paracuellos / P.-J. Benghozi, Télévision, I'ère du numérique, París, La Documentation Française.

KEvin, Deirdre (2015): Snapshot: Regional and local television in Spain, European Audiovisual Observatory.

KEvin, Deirdre (2015): Snapshot: Regional and local television in United Kingdom, European Audiovisual Observatory.

LANGE, André (2011): "Convergence et diversité des systèmes européens», en J.-Ch. Paracuellos / P.-J. Benghozi, Télévision, I'ère du numérique, París, La Documentation Française

LÉvY, Pierre (2007): Cibercultura. La cultura de la sociedad digital, Barcelona, Anthropos.

LloRÉns MaLuquer, Carlos (2008): «Las políticas de Internet de RTVE y la BBC: la redefinición e implementación del servicio público en los nuevos medios», EPTIC, Revista de Economía Política de las Tecnologías de la Información y Comunicación, X(2) (www.eptic.com.br) [última consulta: 20/9/2914].

LóPez CEPEDA, Ana María (2010): Órganos de control e xestión da Radiotelevisión pública estatal e autonómica en España. A cualificación e profesionalidade de Directores xerais, Consellos de Administración, Comisións de Control Parlamentario e Consellos Audiovisuais, tese de doutoramento, Facultade de Ciencias da Comunicación, Universidade de Santiago de Compostela.

López García, Xosé (2010): La metamorfosis del periodismo. Historia de lo que permanece y de lo que cambia en el ciberperiodismo del tercer milenio, Zamora / Sevilla, Comunicación Social.

Manovich, Lev (2005): El lenguaje de los nuevos medios de comunicación: la imagen en la era digital, Barcelona, Paidós.

Manovich, Lev (2008): Software takes command, Nova York, Georgetown University (http://faculty.georgetown.edu/irvinem/ theory/Manovich-Software-Takes-Command-ebook-2008-excerpt.pdf).

Manovich, Lev (2013): Software Takes Command (International Texts in Critical Media Aesthetics), Nova York, Blomsbury.

Marzal Felicl, Javier / Jessica IzQuierdo CAstillo / Andreu CASERo Ripollés (eds.) (2015): La crisis de la televisión pública. El caso de RTVV y los retos de la nueva gobernanza, Barcelona, Aldea Global.

MatTelart, Armand (2007): Historia de la sociedad de la información, Barcelona, Paidós.

MECD (2015): «Anuario de Estadísticas Culturales 2014 | Principales resultados», Ministerio de Educación, Cultura e Deporte (http://www.mecd.gob.es/cultura-mecd/areas-cultura/libro.html).

Negroponte, Nicholas (1995): Ser digital, Bos Aires, Atlántida.

Noguera Vivo, José Manuel (2012): Redes y periodismo, Barcelona, UOC.

Noguera Vivo, José Manuel (2014): Economía de la participación, Madrid, Fundación EOI.

NYT (2014): Innovation, The New York Times (http://www.nytinnovation.com/).

OBS (2014): Yearbook 2014. Television, cinema, video on-demand audiovisual services-the pan-European picture, European Audiovisual Observatory, pdf.

Osterwalder, Alexander (2004): The Business Model Ontology. A proposition in a design science approach, Laussanne, Université de Lausanne, tese de doutoramento.

Osterwalder, Alexander / Yves Pigneur / Christopher L. Tuccl (2005): «Clarifying Business Models: origins, present, and future of the concept», Communications of the Association for Information Systems, 15.

PICARD, Robert G. (2014): «Twilight or New Dawn of Journalism. Evidence from the changing news ecosystem», Journalism Studies, 15, 5.

PICARD, Robert G. / Paolo SICILIANI (eds.) (2013): Report. Is there Still a Place for Public Service Television? Effects of the Changing Economics of Broadcasting, Oxford, Reuters Institute for the Study of Journalism / BBC Trust / Universidade de Oxford.

Prado, Emili (2015): «La televisión pública», en Javier Marzal Felici / Jessica Izquierdo Castillo / Andreu Casero Ripollés (eds.), La crisis de la televisión pública. El caso de RTVV y los retos de la nueva gobernanza, Barcelona, Aldea Global.

PuppIS, Manuel (2010): «Media Governance: A New Concept for the Analysis of Media Policy and Regulation», Communication, Culture \& Critique, 3(2), 134-149. 
PuPPIS, Manuel (2012): «Between independence and autonomous adaptation: The Europeanization of television regulation in non-EU member states», Communications. European Journal of Communication Research, 37(4), 393-416. DOI: 10.1515/ commun-2012-0022.

Puppis, Manuel / Martino Maggetti / Fabrizio Gilardi / Jan Biela / Yannis Papadopoulos (2014): «The Political Communication of Independent Regulatory Agencies», Swiss Political Science Review, 20(3), 388-400.

PWC (2015): «Global Entertainment and Media Outlook 2015-2019» (www.pwc.com).

Report Reuters Digital (2014): «News Report 2014 Tracking The Future of News», Reuters Institute Digital, Reuters Institute for the Study of Journalism.

Rushkoff, Douglas (2014): «The next Big think. On the economy likes», Rhapsody Magazine (http://www.rushkoff.com/storage/ Rhapsody \%20magazine \%20_ \%20Apr \%202014 \%20 \%20Ink \%20eMagazines.pdf).

SABI (2014): Base de datos de Análisis de Balances Ibéricos de Empresas (http://sabi.bvdep.com/ip////).

WAN (2014): «World Trends Database», Asociación Mundial de Diarios, WAN-IFRA (www.wan-ifra.org).

WNMN (2014): «Global Digital Media Trendbooks 2014», World News Media Network (www.wnmn.org). 
A PRENSA GALEGA EN PAPEL:
SEN LUZ AO FINAL DO TÚNEL

Valentín-Alejandro Martínez-Fernández Óscar Juanatey-Boga

Universidade da Coruña

Doi:10.17075/aceg.2016.002 

Xa poucas dúbidas parecen reflectir os datos de difusión dos xornais galegos nos últimos anos sobre as enormes dificultades que atravesa o sector da prensa impresa na Comunidade Galega.

A crise económica e financeira que asolou as economías occidentais en xeral e con especial virulencia a economía española, ou o cambio de paradigma na comunicación social como consecuencia da aparición e desenvolvemento das Tecnoloxías da Información e a Comunicación (Scolari 2008) son, sen dúbida, dous dos factores máis relevantes que hai que considerar para tratar de encontrar explicación a un feito que se constata e recrúa ano tras ano: o sector dos xornais impresos agoniza.

O mercado xornalístico galego segue a sufrir un profundo reaxuste que se manifesta na continua perda de difusión tal e como se recolle mes a mes, ano a ano, nas actas da Oficina de Justificación de la Difusión (OJD), e que amosan unha perda de preto de 50000 exemplares de pago diarios na última década.

O inicio do novo milenio supuxo o punto máximo, o cumio do ciclo de vida dun produto, o xornal impreso, que comezou dende aquela un descenso vertixinoso que o levou dende os preto de 200000 exemplares diarios de difusión nos albores deste século a menos de 150000 na actualidade. En canto á venda ao número, os exemplares vendidos no punto de venda, caeron case que á metade ao pasaren de preto de 140000 exemplares diarios a arredor de 70000 agora mesmo.

Os dous últimos anos, 2013 e 2014, non amosan datos que permitan pensar con maior optimismo. A difusión caeu en case 20000 exemplares dende o ano 2012 e a venda ao numero, en preto de 13000 . 0 único dato que parece manterse é o da difusión gratuíta, que se move arredor dos 10000 exemplares e que polo seu intrínseco carácter non xera senón custos nas contas dos grupos xornalísticos, salvo pola súa repercusión na audiencia total das cabeceiras e con isto nas tarifas da mancha publicitaria, variable, en todo caso tamén en claro declive, nos últimos anos.

Só o nacemento de novos xornais en galego, como foi o caso da confluencia no ano 2012 da aparición de Sermos Galiza e Praza Pública, que nos dous últimos anos amosan datos cando menos esperanzadores en canto ao número de usuarios únicos e visitas, parecen transmitir certa luz ao sector, se ben, por suposto, dentro xa do ámbito exclusivamente dixital.

\section{A PRENSA IMPRESA EN GALICIA: ¿FIN DO SEU CICLO DE VIDA?}

A evolución do sector dos xornais en papel en Galicia amosa con claridade un fenómeno xa descrito e vaticinado por algúns autores nos últimos anos e vinculado á aparición e desenvolvemento da prensa dixital: un proceso de convivencia entre os novos medios e os tradicionais, no que inicialmente uns non chegan a substituír os outros senón que se leva a cabo un proceso de reinvención (Campos 2010). Pero nese proceso, como apunta McLuhan (2009), o novo pouco a pouco oprime o vello ata forzalo a unha nova forma e posición.

Agora ben, non son poucos os autores que formulan que ese proceso está encamiñado, de forma máis ou menos explosiva, á desaparición do xornalismo impreso, que, se ben durante longo tempo supuxo un puntal no sector cultural, está a sufrir una profunda transformación que fai que o seu futuro pareza dubidoso (Carr 2009).

De feito, algúns mostran poucas dúbidas ao respecto, como Meyer (2004), ao establecer a desaparición dos diarios impresos nos Estados Unidos de Norteamérica para o primeiro cuadrimestre do ano 2043, ou como Ramo- 
net (2011), que formula a aparición de Internet para os xornais impresos de forma paralela á chegada do meteorito que provocou a extinción dos dinosauros na Terra hai millóns de anos.

O inicio da segunda década do novo milenio supuxo, sen dúbida, neste sentido un punto de inflexión destacado no que se refire ao sector xornalístico, na medida en que por primeira vez o número de persoas que acceden a Internet a diario superou o de lectores e lectoras de xornais impresos; así, se no ano 2010 por primeira vez a penetración, segundo os datos do Estudio General de Medios elaborado pola Asociación para la Investigación de Medios de Comunicación (AIMC 2014), igualábase entre xornais e Internet nun 38 \%, na actualidade, segundo o último dato ofrecido a finais de 2014, a penetración dos xornais descendeu a un 30 \%, namentres a de Internet continúa cun forte crecemento que sitúa xa a rede nunha taxa de penetración do $60 \%$.

Deste xeito, e xa no que se refire ao ámbito galego, os datos amosan con claridade nos últimos anos una perda constante de difusión das distintas cabeceiras de prensa impresa en Galicia ${ }^{1}$. Así e conforme os datos facilitados pola OJD, como se aprecia no gráfico 1, tanto a difusión total como a difusión de pago -a diferenza entre unha e outra está na difusión de exemplares gratuítos- sofren unha forte caída coincidindo co arranque da crise económica e financeira, un descenso que supón, como media anual, unha perda de 7000 exemplares diarios de pago cada ano que pasa, e que nos últimos anos non fixo senón agravarse, ao caer a difusión media diaria en 11000 exemplares do ano 2011 ao 2012, outros 11000 do ano 2012 ao 2013, e outros 6000 do ano 2013 ao 2014, se ben hai que ter en conta que os datos de 2014 recollen só a media do primeiro semestre do ano.

Gráfico 1. Difusión total e de pago dos xornais galegos en OJD

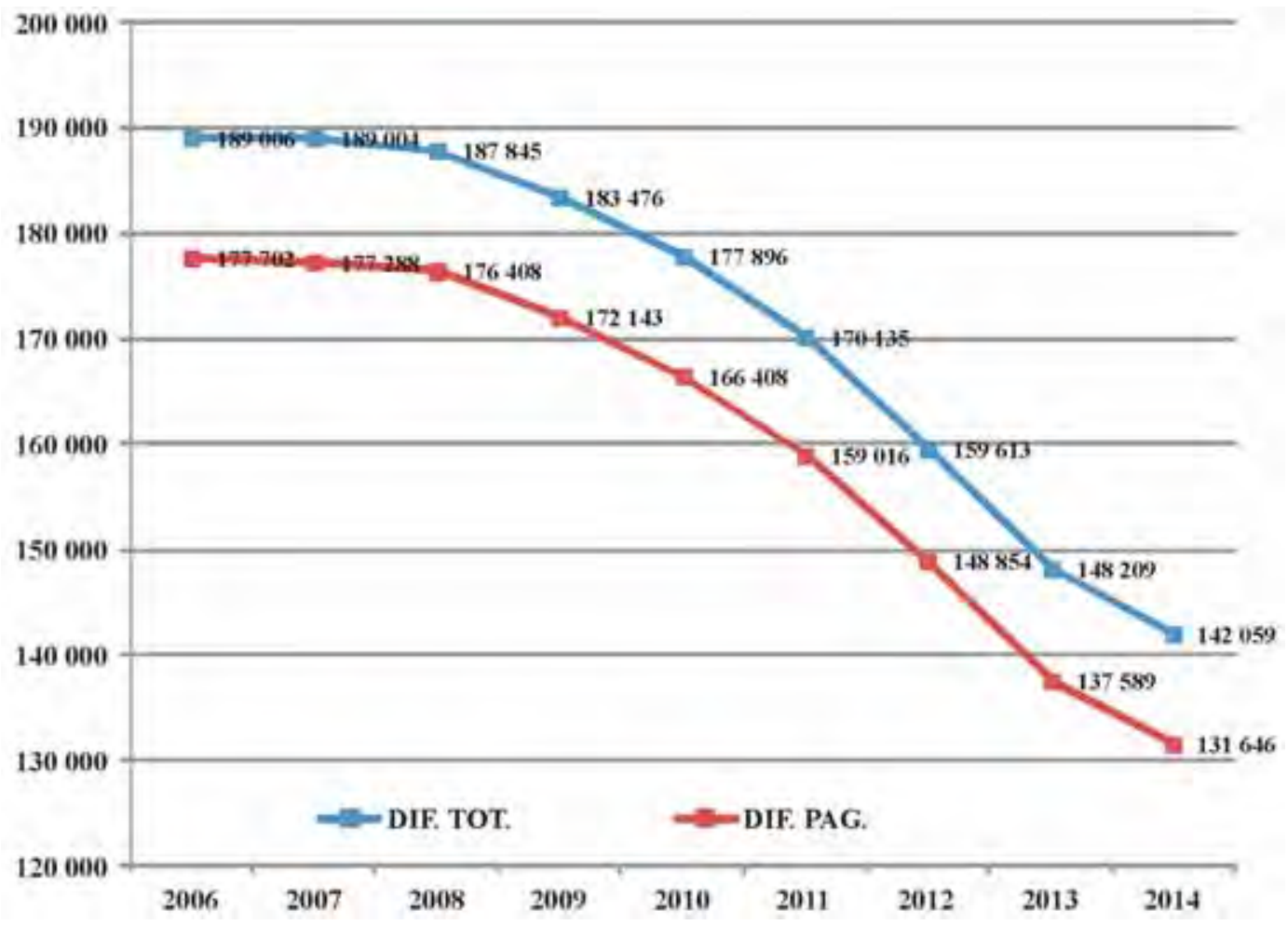

Fonte: elaboración propia a partir de datos da OJD.

\footnotetext{
${ }^{1}$ A pesar da existencia doutros xornais en Galicia como El Ideal Gallego, El Correo Gallego, Diario de Ferrol ou Diario de Arousa, polo feito de non ter a súa difusión acreditada na OJD non se inclúen na análise, pois enténdese que a súa relativamente baixa difusión respecto aos analizados permite que as conclusións nos se vexan significativamente alteradas.
} 
Na mesma liña, a venda ao número, que recolle os exemplares adquiridos polos consumidores finais nos distintos puntos de venda como quioscos, librarías e outros, experimenta un profundo retroceso dende os inicios do novo século, cando, tras acadar un máximo preto dos 140000 exemplares no ano 2002, marca unha mingua media anual de 5500 exemplares diarios, ata perder un total de 66000 exemplares diarios de venda ao numero, o que supuxo un descenso continuo de 12 anos a unha media anual do 5,5\%. Isto pon de manifesto que o consumidor está a sufrir un importante proceso de cambio no seu comportamento e hábitos no que se refire ao seu proceso de compra de xornais, e no que a compra de prensa impresa nas canles máis tradicionais de distribución está claramente a ser abandonada e substituída por outras formas de achegarse á información ofrecida por estes medios de comunicación social.

Estas cifras son similares nos últimos dous anos, 2013 e 2014, pois a venda ao numero caeu máis dun 15 \%, ao perder outros 13000 exemplares de media diaria dende os 84578 de 2012, tal e como se pode apreciar no gráfico 2.

Gráfico 2. Venda ao número dos xornais galegos en OJD

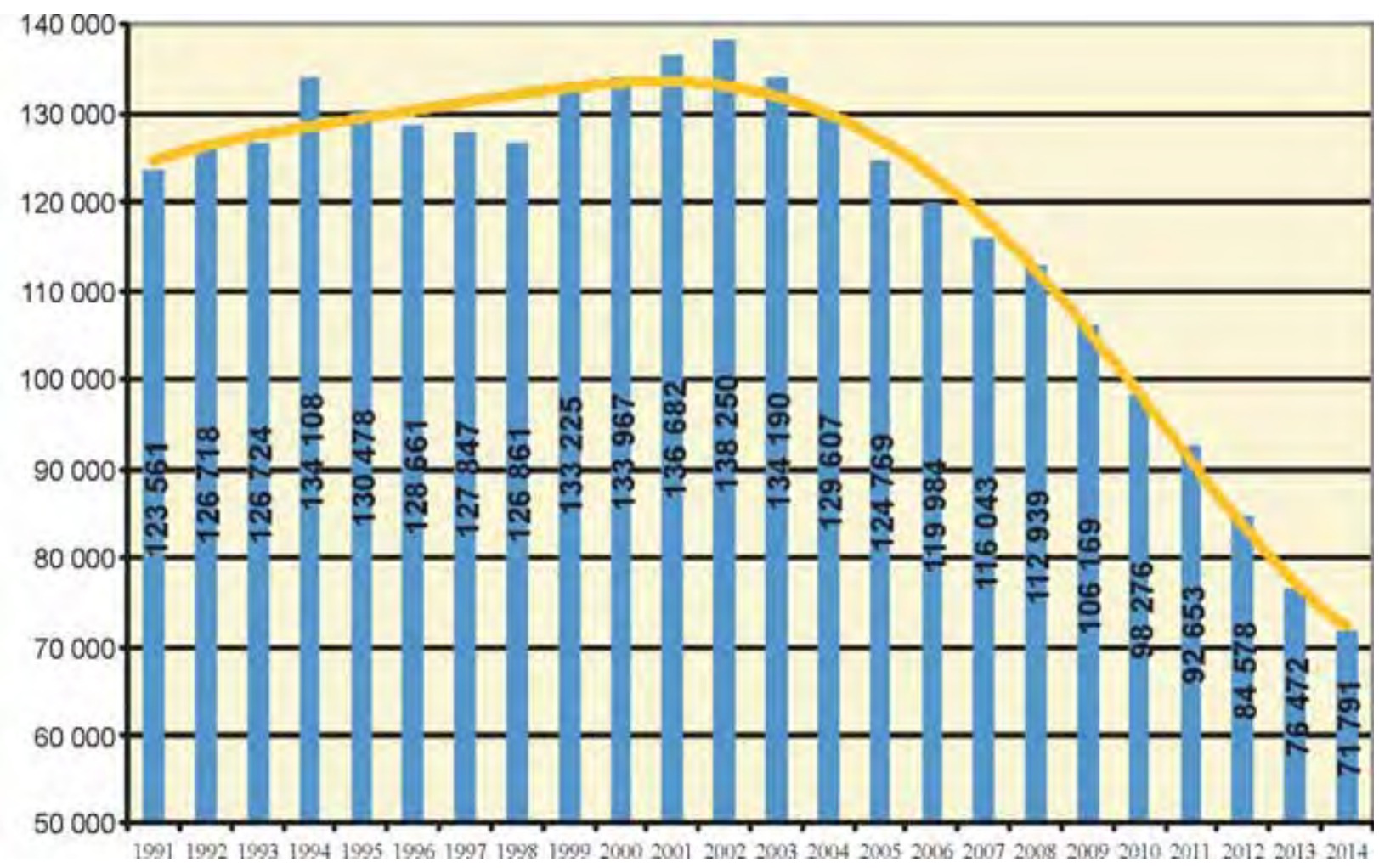

Fonte: elaboración propia a partir de datos da OJD.

A forte caída da difusión desde o inicio da crise económica veu acompañada dun maior esforzo de venda de cada exemplar (Martínez-Fernández / Juanatey-Boga 2013), é dicir, dun incremento de custos na medida en que para vender un exemplar no punto de venda faise necesario un maior número de exemplares á disposición dos consumidores en proporción, de xeito que se hai quince anos se perdía un exemplar como invendido por cada catro vendidos, cun esforzo de venda do 26 \% no ano 2001, na actualidade, nos anos 2013 e 2014, pérdese máis dun exemplar por cada tres que se venden no punto de venda, xa que o índice de esforzo de venda se move por riba do 30 \%, o que supón un incremento dos custos da venda, tal e como se recolle na táboa 1. 
A isto debe engadirse o incremento no número de exemplares difundidos de forma gratuíta, que practicamente se duplicou dende hai vinte anos, aínda que os datos de difusión son case os mesmos, e que nos últimos anos permanecen por riba dos 10000 exemplares diarios a pesar da caída de máis dun 10 \% na difusión de pago nos últimos tres anos, o que só se pode entender como un intento das empresas xornalísticas para manter no posible as cifras de difusión de cara a unha mellor posición negociadora dos seus espazos publicitarios, fonte de ingresos que tamén vén soportando un gran retroceso nos últimos anos segundo os datos de Infoadex (2014) sobre investimento publicitario en España.

Táboa 1. Principais datos da difusión dos xornais galegos na OJD

\begin{tabular}{lrrrrrrrr} 
Xornais de Galicia en OJD & $\mathbf{1 9 9 1}$ & $\mathbf{1 9 9 6}$ & $\mathbf{2 0 0 1}$ & $\mathbf{2 0 0 6}$ & $\mathbf{2 0 1 1}$ & $\mathbf{2 0 1 2}$ & $\mathbf{2 0 1 3}$ & $\mathbf{2 0 1 4}$ \\
\hline DIFUSIÓN TOTAL & 160861 & 176883 & 195638 & 189006 & 170135 & 159613 & 148209 & 142059 \\
\hline DIFUSIÓN DE PAGO & 154438 & 169554 & 185121 & 177702 & 159016 & 148854 & 137589 & 131646 \\
\hline VENDA AO NÚMERO & 123561 & 128661 & 136682 & 119984 & 92653 & 84578 & 76472 & 71791 \\
\hline VENDA EN BLOQUE & 1596 & 3209 & 5871 & 7608 & 9820 & 8128 & 7793 & 7777 \\
\hline SUBSC. NORMAL & 26292 & 32607 & 35519 & 41651 & 48667 & 49100 & 47897 & 47276 \\
\hline SUBSC. COLECTIVA & 2989 & 5077 & 7045 & 8492 & 7894 & 7049 & 5426 & 4802 \\
\hline DIF. GRATUÍTA & 6424 & 7329 & 10518 & 11304 & 11118 & 10759 & 10621 & 10413 \\
\hline INVENDIDOS & 29574 & 37272 & 35855 & 32888 & 27769 & 27046 & 24462 & 24867 \\
\hline ESFORZO DE VENDA & $23,93 \%$ & $28,97 \%$ & $26,23 \%$ & $27,41 \%$ & $29,97 \%$ & $31,98 \%$ & $31,99 \%$ & $34,64 \%$ \\
\hline
\end{tabular}

Fonte: elaboración propia a partir de datos da OJD.

Cómpre, finalmente, destacar nesta análise dos datos agregados que, nos últimos tres anos, dúas das partidas que tradicionalmente ían compensando a perda de difusión, como eran a venda en bloque e a subscrición colectiva, reflicten tamén un importante recorte, lonxe de cifras do lustro anterior, cando dalgún xeito estas partidas de difusión especial, tal e como as cataloga a propia OJD polas súas connotacións, compensaban a perda de difusión ordinaria.

Non obstante, convén destacar que si parece que as empresas editoras de xornais buscaron unha maior fidelización dos lectores a través das subscricións ordinarias, pois o número de compradores que adquirían o seu xornal mediante esta fórmula foise incrementado ata alcanzar preto dos 50000 individuos no ano 2012, se ben nos dous últimos anos, 2013 e 1014, parecen mostrar tamén certos síntomas de debilidade, malia que aínda é cedo para tratar de concluír algunha tendencia nesta variable.

\section{A EVOLUCIÓN DAS CABECEIRAS EN GALICIA}

Ningún xornal galego escapa da dura tendencia actual do sector. É difícil atopar, tal e como se pode apreciar no gráfico 3, algún fío de optimismo. A difusión de todas as cabeceiras galegas recollidas na OJD, sen excepción, mostra unha clara senda baixista, de xeito que sería complicado matizar cal delas vai algo peor ou mellor que as demais, pois a pendente de descenso é moi similar para todas elas e amosa que nos últimos anos o sector se converteu de forma moi marcada no que se podería, sen dúbida, catalogar como un mercado en declive. 
Gráfico 3. A difusión das cabeceiras galegas

Difusión Total La Voz de Galicia

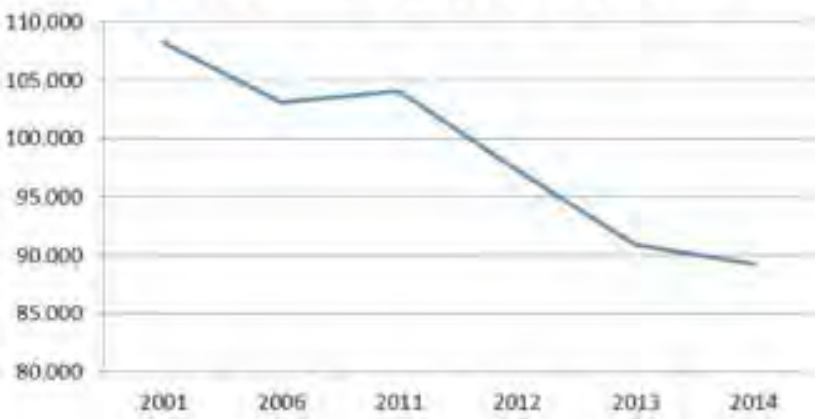

Difusión Total El Progreso

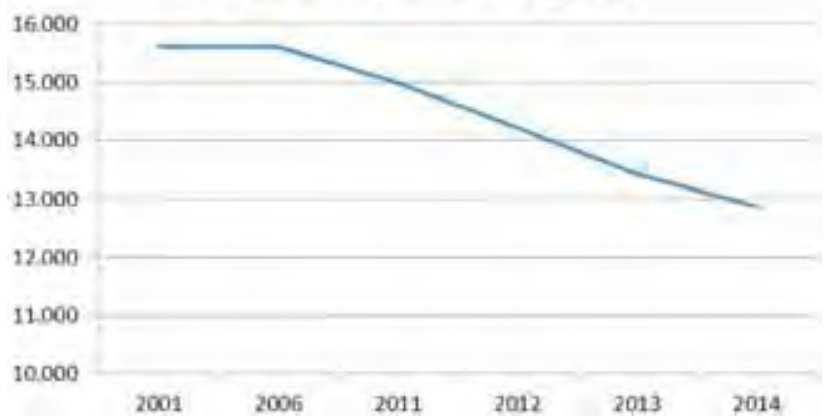

Difusión Total Diario de Pontevedra

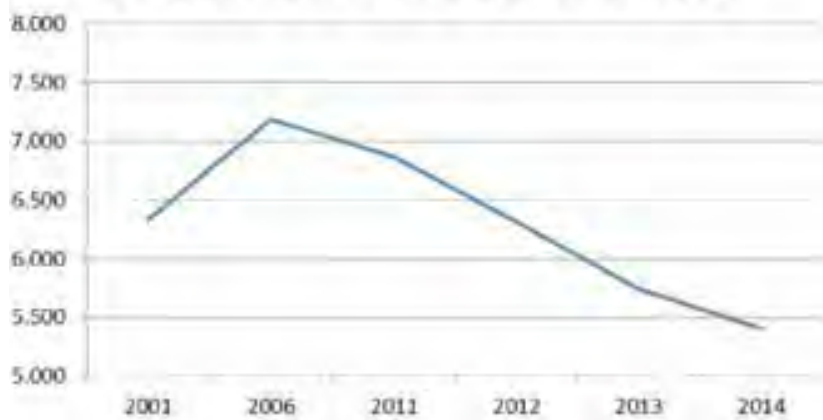

\section{Difusión Total Atlántico Diario}

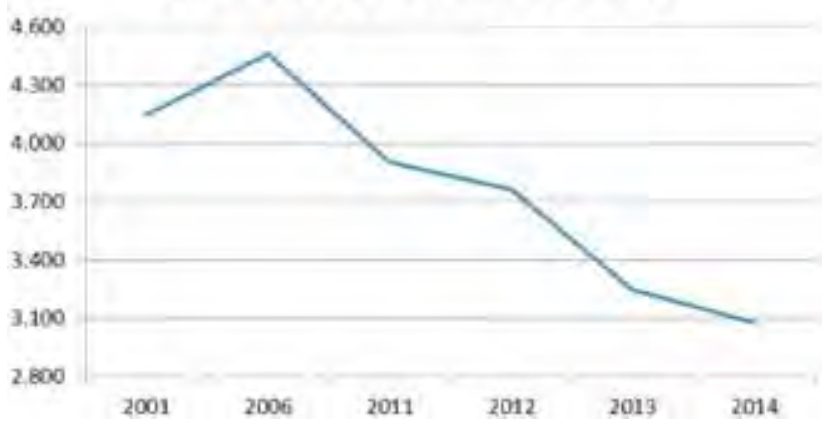

Fonte: elaboración propia a partir de datos da OJD.
Difusión Total Faro de Vigo

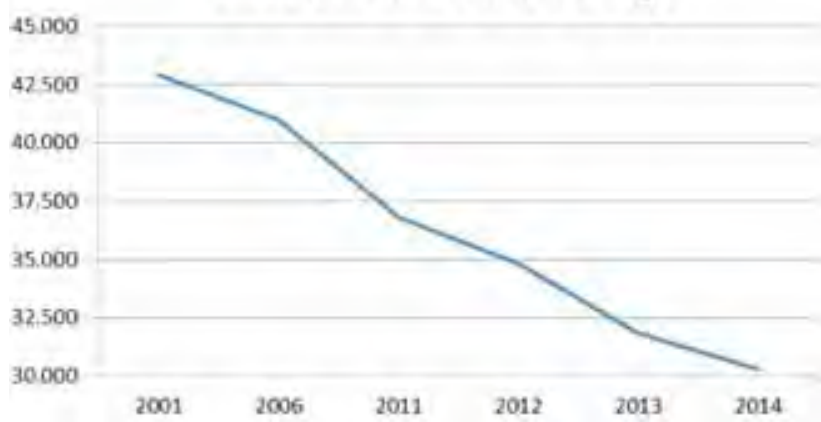

Difusión Total La Región

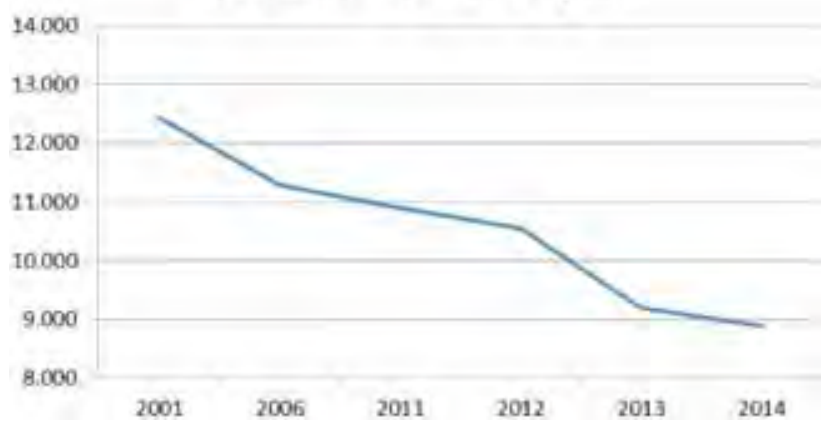

\section{Difusión Total La Opinión Coruña}

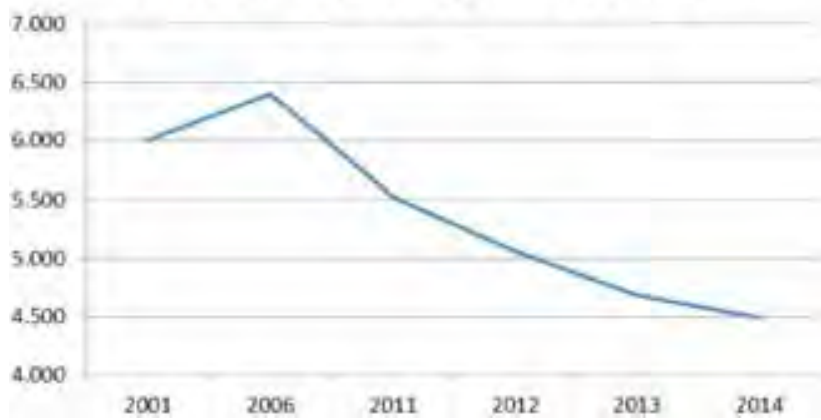

\section{Difusión Total xornais galegos}

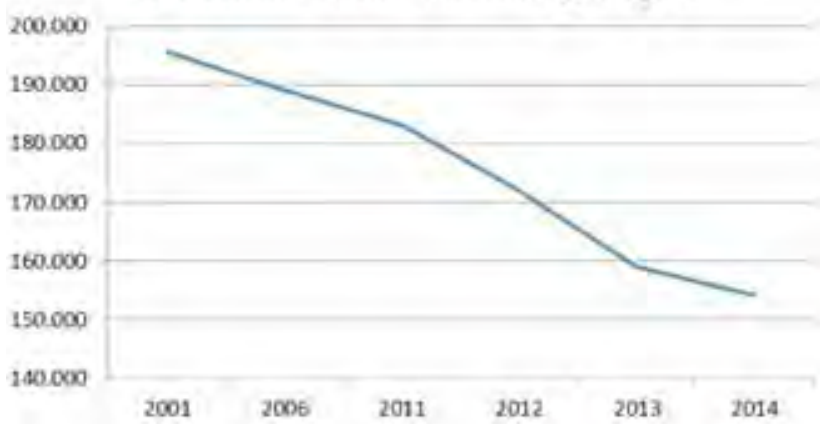


Deste xeito, os distintos xornais galegos perderon unha importante parte tanto da súa difusión total como da referente á venda ao número e, tal e como se recolle na táboa seguinte, as porcentaxes de redución nos tres últimos anos amosan nalgún caso valores próximos ao $30 \%$.

\begin{tabular}{|c|c|c|c|c|c|c|c|c|c|c|}
\hline \multicolumn{2}{|l|}{ Xornais de Galicia en OJD } & 1991 & 1996 & 2001 & 2006 & 2011 & 2012 & 2013 & 2014 & $2014 / 2011$ \\
\hline \multirow[t]{2}{*}{ La Voz de Galicia } & Difusión total & 101727 & 109582 & 108201 & 103093 & 104027 & 97250 & 90883 & 89223 & $-14,2 \%$ \\
\hline & Venda ao número & 83842 & 85134 & 81487 & 70308 & 48650 & 43456 & 39337 & 36749 & $-24,5 \%$ \\
\hline \multirow[t]{2}{*}{ Faro de Vigo } & Difusión total & 34081 & 37429 & 42913 & 40982 & 36816 & 34804 & 31852 & 30272 & $-17,8 \%$ \\
\hline & Venda ao número & 27501 & 29983 & 34335 & 30897 & 28536 & 26788 & 24082 & 22911 & $-19,7 \%$ \\
\hline \multirow[t]{2}{*}{ El Progreso } & Difusión total & 12342 & 13836 & 15610 & 15613 & 14992 & 14220 & 13412 & 12876 & $-14,1 \%$ \\
\hline & Venda ao número & 4890 & 6439 & 7379 & 7445 & 6414 & 6073 & 5637 & 5305 & $-17,3 \%$ \\
\hline \multirow[t]{2}{*}{ La Región } & Difusión total & 12712 & 11095 & 12433 & 11290 & 10905 & 10555 & 9199 & 8880 & $-18,6 \%$ \\
\hline & Venda ao número & 7327 & 6045 & 5486 & 4419 & 3614 & 3191 & 2869 & 2534 & $-29,9 \%$ \\
\hline \multirow[t]{2}{*}{ La Opinión de A Coruña } & Difusión total & & & 6004 & 6392 & 5524 & 5063 & 4682 & 4492 & $-18,7 \%$ \\
\hline & Venda ao número & & 4702 & 3375 & 2406 & 2273 & 2036 & 1934 & $-19,6 \%$ & \\
\hline \multirow[t]{2}{*}{ Diario de Pontevedra } & Difusión total & & & 6332 & 7180 & 6866 & 6313 & 5741 & 5403 & $-21,3 \%$ \\
\hline & Venda ao número & & 2541 & 2989 & 2598 & 2382 & 2189 & 2053 & $-21,0 \%$ & \\
\hline \multirow[t]{2}{*}{ Atlántico Diario } & Difusión total & & 4942 & 4146 & 4457 & 3899 & 3765 & 3246 & 3078 & $-21,1 \%$ \\
\hline & Venda ao número & 1061 & 753 & 552 & 436 & 414 & 323 & 306 & $-29,9 \%$ & \\
\hline
\end{tabular}

Fonte: elaboración propia a partir de datos da OJD.

Así, a difusión total reduciuse para todos os xornais analizados entre, aproximadamente, un $15 \%$ e un $20 \%$, destacando no lado negativo o Atlántico Diario e o Diario de Pontevedra, con valores incluso algo por riba do $20 \%$.

Pero o problema agudízase máis se cabe ao analizar as cifras de venda ao número, pois as porcentaxes de caída son aínda maiores, con valores polo xeral por riba do 20 \% e alcanzando o 30 \% no caso de La Región e do Atlántico Diario.

Esta paisaxe non é distinta para os xornais de información xeral de ámbito nacional que contan con edición para Galicia e teñen auditadas as súas cifras de difusión por parte da OJD, como é o caso de El País e El Mundo. Neste caso, ambas as cabeceiras presentan cifras moi similares tanto en datos como en evolución. Así, a difusión total dos dous xornais cae preto dun $30 \%$, e no caso da venda ao número este descenso supera incluso o $30 \%$ nos últimos tres anos, é dicir, tan só dende o inicio desta segunda década deixaron de vender 1 de cada 3 exemplares que antes vendían, o que pon de manifesto, como xa se evidenciou, a profunda crise do sector con independencia de que se trate de xornais galegos ou non.

\begin{tabular}{llrrrrrrrrrr}
$\begin{array}{l}\text { Edición galega de } \\
\text { xornais nacionais }\end{array}$ & 2007 & 2008 & 2009 & 2010 & 2011 & 2012 & 2013 & 2014 & 2014/2011 \\
\hline \multirow{2}{*}{ El País } & Difusión total & 20950 & 20762 & 18470 & 16390 & 15773 & 14150 & 12585 & 11234 & $-28,8 \%$ \\
\cline { 2 - 11 } & Venda ao número & 17848 & 17392 & 15488 & 13418 & 13274 & 11434 & 9994 & 8833 & $-33,5 \%$ \\
\hline \multirow{2}{*}{ El Mundo } & Difusión total & 21836 & 21829 & 19876 & 18506 & 17560 & 15679 & 14256 & 12355 & $-29,6 \%$ \\
\cline { 2 - 10 } & Venda ao número & 12317 & 11867 & 10743 & 9896 & 9708 & 8845 & 7962 & 6287 & $-35,2 \%$ \\
\hline
\end{tabular}

Fonte: elaboración propia a partir de datos da OJD. 


\section{A PRENSA EN GALEGO: NOVOS SOPORTES, NOVOS MEDIOS, NOVAS ESPERANZAS}

Tras un comezo de década marcado polas malas novas en forma de desaparición do único xornal de pago en galego editado ata ese momento, Galicia Hoxe, no ano 2011, e o peche doutros medios en galego cun certo afianzamento xa en formato dixital, como o caso de Vieiros, o último bienio parece amosar unha certa consolidación dalgúns dos proxectos iniciados recentemente e que dalgún xeito tratan de cubrir o espazo mediático da prensa escrita en galego.

No ano 2012 e con menos de tres meses de diferenza, naceron, cunha clara aposta polo ámbito dixital, dúas cabeceiras como Praza Pública e Sermos Galiza. Ambas as dúas, neste último bienio, parecen lograr un certo asentamento no mercado xa que calquera delas supera o medio millón de usuarios únicos, con crecementos medios anuais dun $20 \%$ nesta cifra.

En paralelo e en consonancia coa súa propia dimensión dixital, estes xornais caracterizáronse por unha proactividade moi importante nas redes sociais como Twitter e Facebook. Así, Praza Pública conta con preto de 15000 seguidores en Twitter e 9000 en Facebook, namentres que Sermos Galiza ten case 13000 adherentes en Twitter e 12000 en Facebook, amosando, como se ve, unhas cifras moi parellas tanto en usuarios únicos na súa web como followers nas principais redes sociais.

A isto deberíase engadir, para finalizar, a edición dun semanario impreso en galego que Sermos Galiza editou case que dende a súa aparición como complemento á súa edición diaria en soporte dixital.

Esta situación parece amosar un caldo de cultivo interesante para que se poida asentar, de xeito máis estable, un ecosistema de xornais en lingua galega que cubran o espazo que outras cabeceiras tradicionais foron pouco a pouco deixando ata ofrecer o que parecía un panorama cando menos preocupante.

\section{CONCLUSIÓNS}

O sector xornalístico galego, no que se refire á súa vertente de edicións impresas, parece abocado, cos últimos datos de difusión que amosan, á súa paulatina desaparición.

Os novos hábitos dos consumidores de produtos informativos, a consolidación da prensa dixital ou, en relación con isto, o propio efecto da pirámide poboacional, na que os máis novos substitúen dende hai tempo o consumo de xornais en papel pola información procedente de Internet, constitúen algúns dos máis relevantes factores que xunto á crise económica e financeira que afectou a economía occidental nos últimos anos explican a forte recesión e declive do sector da prensa impresa non só en Galicia, senón tamén noutros ámbitos xeográficos.

Deste xeito, tanto os principais xornais galegos como aqueles que sen selo contan cunha presenza relevante en Galicia, a través de edicións propias para a nosa Comunidade Autónoma, amosan nos últimos anos unha clara debilidade nas súas cifras de difusión, que xa non parecen reflectir unha tendencia propia dun fenómeno cíclico, senón máis ben dun proceso de ocaso dun sector que está definitivamente obrigado a unha reconversión cara a outros soportes e modelos de negocio que permitan a súa continuidade no tempo.

A edición electrónica dos xornais constitúese deste xeito, e cada vez con máis claridade, na vía para un sector en que as edicións impresas constituirán, nun horizonte non moi afastado, un mercado residual ou nicho no que só outro tipo de produto informativo menos condicionado pola inmediatez que permiten as novas tecnoloxías lle facilite manter unha demanda mínima para a súa supervivencia.

En calquera caso, resulta tamén evidente que as novas tecnoloxías, en especial no que se refire a Internet en xeral e as Redes Sociais en particular, constitúen unha importante oportunidade para consolidar novas formas de practicar o xornalismo que poden facilitar a consolidación dun segmento de prensa en galego que ata o de agora sempre amosou profundas dificultades para a súa consolidación. 


\section{REFERENCIAS BIBLIOGRÁFICAS}

AIMC (2014): Estudios General de Medios, Febrero a Noviembre.

Campos FreiRe, F. (2010): «Los nuevos modelos de gestión de las empresas mediáticas», Estudios sobre el Mensaje Periodístico, 16, 13-30, Madrid, Universidad Complutense.

CARR, N. (2009): El gran interruptor. El mundo en red, de Edison a Google, Barcelona, Deusto.

INFOADEX (2014): Estudio de la Inversión Publicitaria en España.

Martínez-Fernández, V. A. / O. Juanatey-Boga (2013): «A prensa diaria no seu labirinto», en X. López García / M. Rivas Barrós

/ R. Aneiros Díaz (coords.), A comunicación en Galicia 2013, Santiago de Compostela, Consello da Cultura Galega, 47-56. McLuhAn, M. (2009): Comprender los medios de comunicación. Las extensiones del ser humano, Barcelona, Paidós.

MeYer, P. (2004): The Vanishing Newspaper: Saving journalism in the Information Age, Nova York, Publisher Inc.

RAmonet, I. (2011): La explosión del periodismo. De los medios de masas a la masa de medios, Madrid, Clave Intelectual.

ScolARI, C. (2008): Hipermediaciones. Elementos para una Teoría de la Comunicación Digital Interactiva, Barcelona, Gedisa. 


\section{A RADIO EN GALICIA 2012-2014: MÁIS EMISORAS, MENOR NEGOCIO Xosé Ramón Pousa \\ Universidade de Santiago de Compostela}

Doi:10.17075/aceg.2016.003 



\section{INTRODUCIÓN}

No sector radiofónico, o 2012-14 foi un bienio caracterizado polo incremento do número de emisoras legais e a diminución de emisoras alegais en Galicia, que migraron ás novas frecuencias, grazas á posta en marcha da maioría das 124 novas emisoras adxudicadas no ano 2012, coincidindo co final do seu primeiro mandato, pola Xunta de Núñez Feijóo. Con todo, este crecemento en canto ao número de frecuencias legais non é un indicador de boa saúde do medio. Coma o bienio anterior, este período 2012-14 tamén estivo marcado pola crise económica europea e, moi particularmente, pola fonda recesión económica do Estado español, que continúa afectando o tecido industrial e o nivel de vida do conxunto da sociedade.

Esta longa e profunda crise incrementou a xa difícil situación financeira pola que viñan atravesando dende antes da crise económica os medios de comunicación tradicionais, abocados a grandes cambios, orixinados pola transición dixital, a irrupción de Internet e a modificación dos hábitos de consumo de medios por parte das audiencias. A radio comercial, a pesar de non depender como o xornal das vendas do exemplar, que tanto diminuíron nos medios impresos, e estar habituada a cobrar exclusivamente pola publicidade, padece a anemia dun mercado publicitario que non acaba de recuperarse, se ben é certo que na segunda metade de 2014 a publicidade radiofónica modificou a súa curva descendente, anunciando para o 2015 unha lixeirísima repunta do 0,1\%. Pola súa banda, a radiodifusión pública continuou a sufrir os rigores da política de redución de gasto imposta polo Estado dende o 2010 e trasladada á Xunta e aos concellos.

Tanto no sector público coma no privado, a radio viña arrastrando nos oito últimos anos transformacións irreversibles, encamiñadas á súa adaptación ao novo marco tecnolóxico e de mercado. Na radiodifusión comercial, estes reaxustes continuaron orientados fundamentalmente á redución dos custos de produción para paliar as consecuencias da caída dun mercado publicitario actualmente baixo mínimos. Continuaron, deste modo, diminuíndo os postos de traballo das redaccións e dos servizos técnicos e, tamén en estancamento ou descenso, os salarios dos profesionais das emisoras.

No sector público, a reformulación de Radio Nacional de España, iniciada no ano 2006 dentro da reforma emprendida en RTVE, mantívose nas estreitezas impostas hai cinco anos pola contención dos orzamentos, a importante redución do cadro de persoal e, mesmo, dos contidos elaborados pola radio pública estatal en Galicia. A radio pública autonómica -a Radio Galega (RG) - tamén experimentou os fortes axustes orzamentarios ditados polo Goberno galego. A contabilidade -agora unificada- da Compañía de Radio Televisión de Galicia non permite distinguir entre os números da Televisión de Galicia e os propios da Radio Galega, pero o presuposto do ente público autonómico continúa a súa caída, un $11 \%$, en 2013, un 4,24 \%, en 2014. A mesma situación de limitación presupostaría vivírona as 26 emisoras municipais galegas, 15 das cales están integradas baixo o paraugas de EMUGA (Emisoras Municipais de Galicia), compartindo espazos de programación común no proxecto Radiofusión. Unha experiencia apoiada inicialmente polo Goberno Bipartito e a Deputación da Coruña que, anos despois, sofre importantes restricións, ao igual que as 11 emisoras que funcionan independentemente e que tamén viron minguados os seus presupostos por parte dos concellos.

No plano económico, a radiodifusión galega continuou inmersa na crise iniciada en 2008, que afectou o mercado publicitario e, consecuentemente, os recortes na programación, que, coma sempre, afectaron a produción local 
das emisoras de cadea, moitas das cales quedaron convertidas en meros postes repetidores, con «ventás» para a publicidade local. Porén, a Radio logrou manter unha alta taxa de penetración, un 62,6 \% en Galicia, 1,2 puntos superior á media do Estado, situada nun 61,0 \%, segundo datos do Estudio General de Medios (EGM) do ano 2014. O medio radiofónico, no bienio 2012-2014, superou por vez primeira nos últimos tempos unha penetración do $60 \%$, algo que non acontecía dende 1984. Isto supón que en Galicia 6 e cada 10 persoas escoitan diariamente a radio, fronte a 4 que len o xornal ou 8 que ven a televisión. Dato de particular importancia tendo en conta que todos os medios, agás Internet, perden penetración nos últimos anos, se ben hai que ter en conta que Galicia dá a taxa máis baixa do Estado español en canto á penetración de Internet, cun 58,4 \% dos usuarios, fronte a unha media estatal do 60,9 \%. Cataluña está 6,5 puntos por riba de Galicia e Estremadura 2,3 puntos máis, tamén segundo datos do EGM correspondentes ao acumulado de 2014.

\section{MEDIDAS LEXISLATIVAS}

\subsection{Retoques no marco estatal}

O Goberno de Mariano Rajoy modificou, en agosto de 2012, a Lei 7/2010, xeral da comunicación audiovisual, promulgada polo anterior Goberno de José Luis Rodríguez Zapatero, que entrara en vigor o 1 de maio dese mesmo ano. Fronte á ameaza da derrogación e elaboración dun novo proxecto, anunciado nos tempos de oposición, o Goberno do Partido Popular limitouse a efectuar retoques, algúns singularmente significativos, encamiñados a permitir a privatización das emisións autonómicas, medida que o PP de Galicia nunca barallou.

O Goberno xustifica o cambio, dentro do clima de contención do gasto público, como unha medida para «flexibilizar» a prestación do servizo público por parte das comunidades autónomas, de forma que «podrán decidir sobre la prestación del servicio público de comunicación audiovisual, pudiendo optar por la prestación directa o indirecta del mismo», de maniera que «podrán transferirlo a un tercero». Como medida adicional, o cambio permite que os prestadores de servizo público autonómico establezan acordos para a produción ou a edición conxunta de contidos co obxecto de «mejorar la eficiencia de su actividad». Ou, o que é o mesmo, os gobernos poden, a partir de agora, adxudicar directamente a radio e a televisión pública a unha empresa ou empresas de comunicación comerciais. Esta modificación, na mesma liña de limitar o gasto, permite a privatización dos medios públicos autonómicos, baixo o pretexto da redución do gasto público.

Para entender os cambios e a moderación neoliberal do Partido Popular, que rebaixou moitas das súas intencións iniciais, hai que ter en conta que o novo marco legal do Goberno Zapatero xa mudara o complexo panorama lexislativo do sector audiovisual, variando numerosos aspectos reguladores e unificando nunha mesma lei as 12 normativas anteriores. 0 documento, cuestionado en moitos dos seus aspectos polo Partido Popular, foi a culminación dun proceso de liberalización iniciado seis anos atrás coa estruturación da televisión e da radio públicas, que nun primeiro paso desembocou na lei de creación da corporación da RTVE, aprobada en xuño de 2006.

A lexislación socialista do ano 2010 impuxo unha filosofía liberalizadora da radiofonía terrestre privada que afondou na desregularización do sector audiovisual, así como na mingua das competencias que en materia radiofónica dispoñían as comunidades autónomas, especialmente Cataluña, que tiña plenamente desenvolvidas as súas competencias en materia audiovisual. O novo marco legal estatal impulsado nos últimos momentos do Goberno socialista flexibilizou as medidas contra a concentración empresarial no sector radiofónico e estableceu unha redefinición ambigua do termo «servizo público» -ata non hai moito tempo principal xustificación dos medios públicos-como obxectivo tamén compartido polos medios privados.

Este conxunto de medidas liberalizadoras da radiofonía terrestre privada concrétanse na supresión do tradicional modo de concesións por un sistema de licenzas e de comunicación previa que vai facilitar a absorción das pequenas 
emisoras polas grandes cadeas, que, por outra parte, xa non van ter problemas en utilizar diferentes frecuencias nunha mesma cidade. A nova disposición favoreceu descaradamente a concentración empresarial de medios, eliminando as febles medidas anticoncentración vixentes ata o momento que, polo menos sobre o papel, impedían a concesión a un operador de varias frecuencias nun mesmo lugar.

Entre as novidades, a lei fixa un prazo dun ano -incumprido xa de forma reiterada- para a posta en marcha do Plan Técnico de Dixitalización da Radio, instrumento que debería rematar co escenario caótico aberto no ano 2000 polo Plan Técnico Nacional para o Digital Audio Broadcasting (DAB). A lei socialista tranquilizou os operadores tradicionais e puxo punto final ao medo das empresas radiofónicas a quedar fóra do dial dixital, posto que garante a futura emisión en dixital de todas as empresas que operen en analóxico, tanto na Onda Media como na Frecuencia Modulada. Esta visión, moito menos restritiva, explota as grandes posibilidades de crecemento do dial dixital, xa que as novas tecnoloxías dixitais, independentemente do que diga o mercado, permitirán a presenza case ilimitada de emisoras no dial.

Outro dos aspectos modificados polo Goberno de Mariano Rajoy no ano 2012 foi a supresión da Agencia Estatal de Radiocomunicaciones, organismo de carácter plural que tería como misión a vixilancia, control e sanción dos excesos cometidos polos operadores. Así, o «Real Decreto-ley 13/2012, de 30 de marzo, por el que se transponen directivas en materia de mercados interiores de electricidad y gas y en materia de comunicaciones electrónicas» suprimiu este organismo e as súas competencias pasaron á Secretaría de Estado de Telecomunicaciones y para la Sociedad de la Información.

\subsection{A radio pública baixo mínimos}

Oito anos despois da reforma máis importante que sufriron os medios públicos, coa posta en marcha da lei de creación da corporación da RTVE, aprobada en xuño de 2006, a radio pública estatal continúa na súa liña de adaptación ás novas circunstancias, cunha importante diminución do cadro de persoal e dos orzamentos. A contribución do Estado a RTVE descendeu; nos presupostos de 2012, un 37,4 \% con respecto ao ano anterior, en 2013 caeu un 14,5\% máis e estabilizouse en 2014 cun descenso de só o 0,01 \%. Este descenso da participación pública no financiamento dos medios públicos estatais pasou de $12 €$ por persoa e ano aos $6,2 €$ actuais. A consecuencia foi especialmente dura para a programación radiofónica nos circuítos territoriais de RNE coa supresión da maior parte dos contidos territoriais, sobre todo os comarcais e locais canalizados a través de Radio 1 e Radio 5, emisoras que limitaron ao mínimo os contidos da radio pública estatal en Galicia, con consecuencias importantes sobre a audiencia, aínda baixo mínimos históricos. A perda dos contidos de proximidade na radio pública estatal é alarmante, sobre todo se temos en conta que en RNE-5 chegaron a supoñer o 30 \% da grella de emisión (Ortiz Sobrino 2012), con 47 desconexións diarias para emitir noticias de carácter local e autonómico. Unha investigación realizada neste sentido no ano 2007 pon de manifesto a importancia da achega dos centros locais e territoriais de Radio 5 á información emitida para todo o Estado (Chomón 2011: 199-216). Os resultados reflicten que o 71 \% das noticias canalizadas pola emisora procedían dos centros territoriais, o que implicaba unha gran descentralización da visión do Estado, agora perdida e recentralizada máis que nunca.

A nivel autonómico, os presupostos da Compañía de Radiotelevisión de Galicia (CRTVG ) seguiron neste bienio a liña de baixada marcada nos últimos seis anos e que colocan o ente público galego nunha situación orzamentaria insostible, ata o punto que os gastos de persoal supoñen o $50 \%$ do presuposto total, a achega da Xunta sitúase nun $89,9 \%$ dos orzamentos e a publicidade queda en apenas un 7,4 \%, segundo as últimas previsións para 0 2015. Os presupostos da CRTVG tiveron un recorte en 2012 con respecto ao ano anterior do 3,2 \%, seguiron á baixa en 2013 cun recorte do 11,3 \% e tamén en 2014 cunha caída do 4,24 \%; co que se situaron en 99,4 miIlóns de euros fronte aos 121,5 millóns de 2011. A unificación dos orzamentos da CRTVG, que dende o ano 2012 dificultan analizar as contas da Radio Galega e da Televisión de Galicia, impiden afondar na evolución das cifras da 
RG, se ben os principais capítulos orzamentais seguen a mesma liña evolutiva nos dous medios do ente e a RG é a irmá pobre da corporación, cun gasto aproximado do $10 \%$ do presuposto da CRTVG. No caso da Radio Galega, as circunstancias económicas obrigaron a un importante recorte orzamentario que supuxo un descenso superior ao 17 \% no presuposto de explotación, se comparamos as cifras de 2009 coas de 2012, sendo actualmente inferior ao de hai catro anos. Os recortes afectaron principalmente os gastos de persoal, retransmisión e equipos, e traducíronse nunha perda de calidade na programación que, así e todo, non significou perda na audiencia.

A radio pública municipal segue sumida nun escenario precario, con poucas emisoras activas en relación co número de concellos e dominado por un modelo de xestión maioritariamente dependente dos cada vez máis febles orzamentos municipais. Nesta situación, as emisoras continúan vivas grazas ao entusiasmo e voluntarismo do persoal que traballa neste tipo de emisoras. Galicia conta cun frouxo tecido de emisoras municipais, vertebrado maioritariamente arredor provincia da Coruña e, con menor incidencia, en Pontevedra e con moi pouca presenza nas interiores de Lugo e Ourense. A pesar dos importantes recortes nos orzamentos dos concellos e dos cambios no mapa político municipal a raíz das eleccións de 2011, a radio municipal non sufriu grandes cambios. Radiofusión, liderado polo histórico da radio comunitaria en Galicia Henrique Sanfiz, que agrupa a 13 emisoras -4 menos que en 2012-, continúa a ser a experiencia máis dinámica da radio local en Galicia. Emiten programación local e comparten unha «ventá» de programación conxunta para todo o circuíto. O proxecto Radiofusión, nacido baixo o amparo do Goberno Bipartito (2005-2009), apoiado máis tarde pola Deputación da Coruña (2009-2011), leva anos excluído de toda axuda pública, mesmo a que a Dirección Xeral de Medios outorga á programación en galego, da que quedan fóra por tratarse de asociacións sen ánimo de lucro e non de sociedades mercantís como esixe a normativa da Xunta. Radiofusión sobrevive grazas aos recursos publicitarios que ela mesma xera. A pesar da crise, neste bienio a radio municipal só sufriu o peche de dúas emisoras: Radio Arteixo (A Coruña) e Radio Poboa de Brollón (Lugo), así como o caso escandaloso das emisoras «arrendadas» alegalmente que emitían programacións comerciais: $\mathrm{A}$ Pobra, Noia, Santa Comba, Touro, O Vicedo, Arbo e Cambados. Este saneamento do medio radiofónico municipal é consecuencia directa da posta en mans dos operadores comerciais de novas frecuencias.

\subsection{Novas licenzas comerciais e menos empresas}

A radio, coma os demais medios de comunicación, sofre un proceso de concentración empresarial imparable dende a década dos oitenta. Nestes últimos trinta anos, o número de emisora multiplicouse por tres pero, contraditoriamente, o número de empresas tende a reducirse. Con esta eliminación de operadores -menos empresas con cada vez máis canles- tamén se limita o pluralismo informativo que pretendía o «Plan Transitorio del Servicio Público de Radiodifusión Sonora en Ondas Métricas con Modulación de Frecuencia», aprobado en xuño de 1979 para rachar o monopolio de RNE e dar paso a unha radiodifusión democrática. O fenómeno da concentración é consecuencia «da falla de criterios obxectivos nas sucesivas ondeadas de concesións que contribúen a prefigurar un sistema mixto de radiodifusión articulado arredor de tres ou catro grandes grupos» (Franquet 2008: 13). Hoxe, o grao de concentración vén avalado polo volume de negocio, propiedade, audiencia e recursos publicitarios, que fan da Cadena SER, Onda Cero e COPE un oligopolio que pon en cuestión a pluralidade informativa. Estas tres empresas suman 1023 frecuencias radiofónicas, absorben o $74 \%$ dos ingresos publicitarios do sector e máis do 78 \% da audiencia radiofónica convencional e do $80 \%$ da radio musical, en 2014.

A absorción da cadea ABC Punto Radio pola COPE, materializada no mes de marzo de 2013, é a última posta en escena deste galopante proceso de concentración no medio radiofónico que, a medio prazo, podería desembocar na fusión de Onda Cero Radio e a COPE, un dos anhelos do centro-dereita español, representado polo Partido Popular. A integración de ABC Punto Radio na COPE produciuse despois dun coqueteo con Onda Cero. ABC Punto Radio era a cadea xeralista do grupo Vocento, con accionistas minoritarios como Luis de Olmo, que tras o acordo, ratificado en decembro do ano 2012, puxo en mans da COPE 76 emisoras que pasaron a transmitir a programa- 
ción convencional da emisora da Igrexa e, alí onde a COPE xa tiña emisión, canalizaron os formatos musicais da radio da Igrexa (Cadena 100, Rock FM e MegaStar FM). A COPE fíxose cargo exclusivamente das frecuencias e non do persoal das emisoras. En Galicia, a totalidade das 7 emisoras legais de ABC Punto Radio -tamén utilizaba frecuencias alegais- pasaron a mans da COPE: as de Lugo (88.9 FM) e Ourense (89.9), que transmitiron a programación convencional; as da Coruña (90.3 FM), Santiago de Compostela (100.2 FM) e Pontevedra (106.9 FM), a programación Rock FM; a emisora de Ferrol (101.3 FM), a de Cadena 100; e a de Vigo (106.7 FM), a fórmula musical MegaStar FM.

O actual bienio estivo marcado pola tardía concesión (DOG, 1 de agosto de 2013) e pola paulatina posta en marcha de gran parte das novas emisoras de radio comercial concedidas polo Goberno de Núñez Feijóo. A convocatoria de emisoras de radio en FM, publicada un ano antes no Diario Oficial de Galicia do 30 de xullo de 2012, afectaba un total de 84 novas emisoras comerciais en Galicia, das cales 28 están na provincia da Coruña, 25 están localizadas na provincia de Lugo, 21 na de Ourense e 10 na de Pontevedra.

Este incremento do Sistema Radiofónico -o derradeiro en tecnoloxía analóxica- parte da regulación do espazo radiofónico efectuado polo primeiro Goberno de Rodríguez Zapatero. O mesmo día en que o Consello de Ministros deu luz verde á constitución da Corporación de RTVE o 1 de setembro de 2006, o Goberno aprobou un novo Plan Técnico Nacional de Radiodifusión Sonora en Ondas Métricas con Modulación de Frecuencia, que permite a concesión de 1101 novas emisoras, nun intento por «legalizar» parte das máis de 2000 emisoras que emitían ilegalmente en España e que foran obxecto de reiteradas denuncias por parte do sector.

Galicia recibiu do Estado un total de 124 novas frecuencias de emisión: 76 comerciais, ampliadas logo a 84, coa inclusión da renovación de licenzas a 15 emisoras concedidas en 1990, e 40 públicas (destinadas a RNE e $\mathrm{RG}$ ), o que representa case o $80 \%$ das 150 solicitadas naquel momento pola Xunta. O Goberno Bipartito, falto dunha política común de comunicación entre PSdeG e BNG, tampouco foi quen de adxudicar ese amplo paquete de licenzas, pensado para resolver o problema do máis dun cento de emisoras que emitían ilegalmente en Galicia ata o 2012. Coincidindo co Plan técnico, un estudo da USC detectou un total de 107 emisións ilegais en Galicia: 44 na provincia da Coruña, 42 en Pontevedra, 11 en Ourense e 10 na provincia de Lugo. Na súa inmensa maioría eran repetidores de emisoras do sistema comercial español que trataban de cubrir áreas poboacionais nas que non tiñan frecuencias radiofónicas.

A concesión da Xunta compraceu novamente, aínda que de forma desigual, os operadores tradicionais, ao priorizar as emisoras con implantación a nivel de Estado, e as empresas de comunicación tradicionais, excluíndo novos operadores. Das 84 emisoras ofertadas, 5 emisoras non foron adxudicadas, en primeira instancia, por falta de promotores: Quiroga (Lugo), Avión, Lobios e Viana do Bolo (Ourense) e Arbo (Pontevedra). Posteriormente foron adxudicadas directamente, fóra de concurso.

A Cadena SER mostrou na súa páxina web o seu descontento co repartimento de Feijóo, a pesar de que foi dos máis beneficiados, cun total de 12 emisoras. Claro que as licenzas foron ás empresas asociadas en Galicia e non directamente ao grupo PRISA. Así, Agrupación Radiofónica, Radio Coruña, El Progreso de Lugo, Radio Ourense, Radio Pontevedra e Radio Vigo recibiron unha ducia de emisoras para explotar en asociación con PRISA, que só conta en propiedade con tres licenzas da emisora Radio Galicia en Compostela.

Cadena COPE, con 13 emisoras, foi o grupo máis beneficiado polo repartimento, seguido por Radiovoz (La Voz de Galicia), con 10 frecuencias. Atresmedia (Onda Cero), con 8 emisoras; Radio Galicia, con 8 emisoras; Prensa Ibérica e Radio María, con 6 emisoras; Es Radio, con 4 licenzas, e Radio Líder e Intereconomía, con 2 licenzas. 0 punto anecdótico foi a concesión dunha emisora a Punto Radio, que xa non existía no momento da adxudicación. 
Novas licenzas na Coruña

\begin{tabular}{|c|c|c|c|}
\hline Localidade & $\mathrm{MHz}$ & Programación & Empresa \\
\hline Arzúa & 95.4 & Onda Cero Santiago & Agrupación Radiofónica S.A. \\
\hline Arzúa & 97.7 & Radio Líder & Medios Autonómicos de Radiodifusión Gallegos \\
\hline Carballo & 88.5 & SER & Radio Coruña S.L. \\
\hline Carballo & 92.4 & Es Radio & Libertad Digital S.A. \\
\hline Carballo & 96.4 & & Radio Marineda S.L.U. \\
\hline Carballo & 97.0 & & La Opinión \\
\hline Carballo & 97.8 & & Ed. La Capital \\
\hline Cariño & 89.9 & & Friol Produccións S.L. \\
\hline Cariño & 101.9 & & Multimedia de Comunicaciones S.L. \\
\hline Cariño & 105.8 & Fórmula Fun Radio & Iniciativa Gallega de Comunicación S.A. \\
\hline Cee & 94.2 & Radiovoz Bergantiños & La Voz de Galicia \\
\hline Cee & 95.7 & SER & Radio Coruña S.L. \\
\hline A Coruña & 87.7 & & Sauzal 66 S.L. \\
\hline A Coruña & 99.9 & Mega Star & COPE \\
\hline A Coruña & 105.8 & Radio Marca & Unidad Editorial \\
\hline Ferrol & 90.6 & & RTV Ferrol \\
\hline Ferrol & 93.0 & & Radio Coruña S.L. \\
\hline Ferrol & 103.2 & Rock FM R. Altas & COPE \\
\hline Muros & 97.3 & Radiovoz & La Voz de Galicia \\
\hline Muros & 103.8 & Radio Obradoiro & Editorial Compostela S.A. \\
\hline Ordes & 97.6 & Cadena Dial & Editorial Compostela S.A. \\
\hline Santiago & 87.6 & Es Radio & Libertad Digital S.L. \\
\hline Santiago & 88.9 & Cadena Cien & COPE \\
\hline Santiago & 95.3 & Onda Cero & UNIPREX S.A.U. \\
\hline Santiago & 105.6 & R. Intereconomía & Sauzal 66 S.L. \\
\hline Vimianzo & 99.5 & Radiovoz Bergantiños & La Voz de Galicia S.A. \\
\hline Vimianzo & 100.1 & Onda Hit & \\
\hline
\end{tabular}

Novas licenzas en Lugo

\begin{tabular}{lcll}
\hline Localidade & MHz & Programación & Empresa \\
\hline Becerreá & 88.4 & Kiss FM Lugo & Kiss Radio S.A. \\
\hline Becerreá & 101.9 & & Radio Amanecer S.A. \\
\hline Chantada & 100.1 & COPE & COPE \\
\hline Chantada & 106.1 & & Kiss Radio S.A. \\
\hline A Fonsagrada & 94.8 & & Kiss Radio S.A. \\
\hline A Fonsagrada & 101.5 & & Radio Amanecer S.A. \\
\hline Foz & 88.8 & & El Progreso S.A. \\
\hline Foz & 95.0 & & Radio Publi S.L. \\
\hline Lugo & 93.3 & Europa FM Lugo & UNIPREX S.A.U. \\
\hline Lugo & 93.7 & & Radio Lugo S.A. \\
\hline Lugo & 98.9 & & El Progreso S.A. \\
\hline Monforte & 87.8 & Radiovoz & La Voz de Galicia S.A. \\
\hline Monforte & 91.8 & Onda Cero Lugo & UNIPREX S.A.U \\
\hline
\end{tabular}


Novas licenzas en Lugo

\begin{tabular}{lrll}
\hline Localidade & MHz & Programación & Empresa \\
\hline Navia de Suarna & 96.9 & & Iniciativa Galega de Comunicación S.A. \\
\hline Palas de Rei & 93.3 & Radio Obradoiro & Editorial Compostela S.A. \\
\hline Palas de Rei & 97.5 & & Iniciativa Galega de Comunicación S.A. \\
\hline Quiroga & 93.4 & & \\
\hline Ribadeo & 91.7 & Onda Cero Lugo & UNIPREX S.A.U. \\
\hline Sarria & 90.6 & Es Radio Lugo & Libertad Digital S.A. \\
\hline Sarria & 97.5 & Mega Star & COPE \\
\hline Vilalba & 103.0 & Radiovoz & Voz de Galicia S.A. \\
\hline Viveiro & 88.5 & Radiovoz & Voz de Galicia S.A. \\
\hline Viveiro & 97.0 & & El Progreso S.A. \\
\hline Viveiro & 99.7 & COPE de la Costa & COPE \\
\hline
\end{tabular}

Novas licenzas en Ourense

\begin{tabular}{lrll}
\hline Localidade & MHz & Programación & Empresa \\
\hline Allariz & 97.6 & Es Radio Ourense & Libertad Digital S.A. \\
\hline Allariz & 106.1 & Sí Radio Ourense & Iniciativa Gallega de Comunicación S.A. \\
\hline Avión & 106.0 & & \\
\hline O Barco & 88.4 & & Faro de Vigo \\
\hline O Barco & 90.9 & & Kiss Radio S.A. \\
\hline O Carballiño & 92.0 & Onda Cero Ourense & UNIPREX S.A.U. \\
\hline O Carballiño & 89.4 & & Agrupación Radiofónica S.A. \\
\hline Celanova & 93.7 & Mega Star F.M. & COPE \\
\hline Celanova & 89.0 & Radio María Ourense & Friol Produccións S.L. \\
\hline Lobios & 100.1 & Radio Líder Ourense & Medios Autonómicos de Radiodifusión Gallegos \\
\hline Ourense & 89.4 & & \\
\hline Ourense & 90.2 & & Faro de Vigo S.A. \\
\hline Ourense & 102.4 & COPE & COPE \\
\hline Ribadavia & 103.9 & & Radio Ourense S.A. \\
\hline Ribadavia & 98.5 & Onda Cero Ourense & UNIPREX S.A. \\
\hline Verín & 101.8 & & Kiss Radio S.A. \\
\hline Verín & 97.1 & & Faro de Vigo S.A. \\
\hline Viana do Bolo & 103.9 & & UNIPREX S.A. \\
\hline Xinzo Limia & 96.9 & & La Voz de Galicia S.A. \\
\hline Xinzo Limia & 99.3 & & Onda Cero Ourense \\
\hline
\end{tabular}

Novas licenzas en Pontevedra

\begin{tabular}{lrll}
\hline Localidade & MHz & Programación & Empresa \\
\hline Arbo & 97.0 & & \\
\hline A Estrada & 92.2 & SER Pontevedra & Radio Pontevedra S.A. \\
\hline A Estrada & 94.9 & & Faro de Vigo S.A. \\
\hline A Estrada & 99.9 & Mega Star FM Santiago & COPE \\
\hline Lalín & 101.3 & Radio Obradoiro & Editorial Compostela S.A. \\
\hline
\end{tabular}


Novas licenzas en Pontevedra

\begin{tabular}{lrll}
\hline Localidade & MHz & Programación & Empresa \\
\hline Pontevedra & 97.0 & & Faro de Vigo S.A. \\
\hline Pontevedra & 103.6 & Onda Cero & UNIPREX S.A.U. \\
\hline Tui & 105.1 & SER Baixo Miño & Radio Vigo S.A. \\
\hline Vilagarcía & 96.7 & & Radio Publi S.L. \\
\hline
\end{tabular}

*As emisoras en que non figura a programación aínda non estaban activas o 1 de febreiro de 2015.

\section{A RADIO ESTABILIZA A PENETRACIÓN E A AUDIENCIA}

Neste período 2012-2014, a radio continúa a dar mostras de vitalidade, mantendo a súa estabilidade na penetración social fronte á caída dos outros medios tradicionais. Así, a nivel estatal, o medio radiofónico acadou en 2013 unha penetración do $61,5 \%$ e en 2014, do 61,0 \%, segundo os datos dos acumulados febreiro-novembro do Estudio General de Medios. No ano 2014 a radio obtivo unha penetración en Galicia dun 62,6 \%, 1,2 puntos superior á media do Estado. A radio rompe, así, unha vez máis, a tendencia á perda de penetración social que caracteriza os medios tradicionais, como a prensa diaria, que, en dez anos, pasou dunha penetración do 41,1 \% no ano 2004 ao 29,8 \% en 2014. A televisión, aínda que continúa a ser o medio con maior incidencia, tivo en 2014 unha penetración do 88,6 \%, lonxe das cifras superiores ao 90 \% de hai algúns anos.

Esta cifra de penetración da radio supón que algo máis de 6 de cada 10 persoas escoitan diariamente algunha emisora de radio, sendo a mellor dos últimos 15 anos e case cinco puntos superior ao 56,8 \% obtido en 2004, cando a crise aínda non chegara aos medios de comunicación. É certo que o medio radiofónico, sobre todo a radio xeralista, na que prima a información e a opinión, perdeu grande parte do público xuvenil e produciuse o envellecemento da audiencia, pero a maior oferta de formatos musicais e a presenza da radio na rede contribuíron a paliar lixeiramente esta tendencia, consecuencia do cada vez menos interese da mocidade polos xéneros convencionais e a programación xeralista tradicional e a súa preferencia por contidos máis especializados e participativos. Neste sentido, a radio na rede, contabilizada a partir do ano 2012 polo EGM, supón arredor do 5 \% da audiencia, o que equivale a que 50000 galegos entren mensualmente nas webs das distintas emisoras da globalidade que representa Internet, sendo un paso definitivo cara a unha radio plenamente dixital, hiperespecializada e máis interactiva.

A radio non só mellorou a súa penetración nos últimos dez anos, segundo datos do EGM, a subida de audiencia por sexos foi maior no segmento das mulleres, cunha suba de máis de 8 puntos, aínda que tamén afectou os homes, que aumentaron 3,4 puntos.

Por idades, o segmento dos máis novos, comprendidos entre os 14 e os 19 anos, subiu 2,1 puntos e pasou do 54,5 ao 56,3; os comprendidos entre 20 e 24 anos descenderon 0,9 puntos; os de 25 a 34 años aumentaron 4 puntos; os de 35 a 44 anos foron os segundos que máis incrementaron a súa porcentaxe, cun $9,7 \%$, e o segmento de 45 a 54 anos aumentou un 8,3\%; os de 54 a 65 anos foron os que máis incrementaron e fixérono nun 9,8 \%; os de 65 e máis anos creceron un 3,8\%.

\subsection{A audiencia en Galicia}

Cada día 1473000 galegos, $52 \%$ homes e $48 \%$ mulleres, escoitan a radio en Galicia unha media de 111 minutos, 6 minutos menos que a media estatal. Algo máis da metade, 810000 galegas e galegos, opta pola radio xeralista e escoitan, por orde de importancia, as seguintes emisoras: Cadena SER (309 000 ouvintes en días laborais, 25000 menos que hai 4 anos), Radio Galega (157 000, 10000 máis que hai catro anos), Onda Cero 
(148 000, 50000 máis que en 2008), COPE (133 000), RNE (96 000, 42000 máis), EGM non facilita datos de Radiovoz (28 000 en 2008) nin de Punto Radio (11 000 en 2008).

A radio temática é seguida cada día por 827000 galegos e galegas: Cadena 40 (243000 ouvintes en días laborais), Cadena 100 (190 000), Dial (102 000), M80 (44 000), Kiss FM (46 000), Máxima FM (27 000), Radio Marca (45 000), RNE3 (25 000). En Galicia, a audiencia radiofónica dá mostras de certo envellecemento. Só o 12,9 \% dos ouvintes son menores de 24 anos. $043 \%$ ten entre 25 e 44 anos. 0 30,4 \%, entre 45 e 60 anos, e case o $15 \%$ son maiores de 65 anos. Todo segundo se desprende dos datos do Estudio General de Medios outubro-novembro 2008.

\section{CONCLUSIÓNS}

O bienio 2012-14 caracterízase polo peche do dial analóxico das bandas de OM e FM que, seguramente, non se van modificar ata a chegada, se algún día chega, do «apagamento analóxico» e o pase ao dial dixital, etapa que a televisión xa pechou en toda Europa en 2012. As últimas concesións analóxicas resolveron en boa medida o altísimo número de emisoras fóra da legalidade, pero non serviron para modificar un modelo radiofónico no que apenas queda espazo para a comunicación, xa non en galego, senón sobre Galicia, ao tratarse dun sistema radiofónico dominado pola estratexia das grandes cadeas españolas que case non deixan cabida para o que poderiamos denominar «espazo radiofónico galego», algo inexistente ata o momento, e reflicte o fracaso das políticas de comunicación da Xunta de Galicia, dende que en 1981 asumiu plenas competencias en materia radiofónica.

Nunha comunidade con lingua propia e cultura específica, a radio que se pode escoitar en Galicia apenas se diferenza da que un pode ouvir en Estremadura ou noutra comunidade española. Non se trata de impedir a existencia de produtos radiofónicos comerciais e públicos de ámbito estatal, senón de equilibrar o sistema radiofónico con contidos propios. Neste sentido, o dial galego é consecuencia de trinta anos de competencias falladas en materia de radiodifusión, nos que houbo gobernos conservadores, pero tamén progresistas que se comportaron do mesmo xeito. Seguramente, contrariamente ao sucedido en Cataluña, a Xunta careceu da presión dunha clase empresarial dinámica, necesaria para adxudicar emisoras a operadores galegos con proxectos comunicativos propios. 0 certo é que, agás o caso de empresas como La Voz de Galicia e El Correo Gallego, o resto dos concesionarios galegos puxeron as súas concesións no mercado para cubrir as necesidades das grandes cadeas.

O sistema radiofónico altamente centralizado permitía, ata non hai moitos anos, a incorporación de contidos locais. Hoxe a radio está sumida na estratexia de redución de custos e de concentración empresarial do sector. Vivimos nas últimas décadas unha continúa diminución dos espazos radiofónicos locais e, mesmo, a inserción da publicidade local en «ventás» dentro dos grandes programas de cadea. A esta estratexia da radio comercial súmase na última década a brutal reconversión da radio pública estatal, cunha importante caída da produción propia en Galicia e, polo tanto, dos contidos elaborados en idioma galego.

Os datos de audiencia deste bienio, sobre todo do último ano, reflicten a recuperación da credibilidade da radio pública, tanto estatal como autonómica. RNE, que presentou en 2010 as cifras máis baixas da historia en Galicia, con apenas 54000 ouvintes, acaba de recuperar gran parte da súa audiencia. A Radio Galega, que perderá case 40000 ouvintes con respecto a 2006, medrou un $10 \%$ a súa audiencia e a radio municipal non consegue entrar, unha vez máis, no EGM. Na radio municipalista, cabe resaltar, unha vez máis, o esforzo de Radiofusión, que, a partir do ano 2008, conta cunha plataforma en Internet, para facilitar a sinerxía de grupo posta en marcha por EMUGA, de cara a ofrecer contidos comúns entre as emisoras que conforman a plataforma. 
ANEXO

Táboa 1. Sistema radiofónico galego. (Emisoras legalizadas)

\begin{tabular}{lccc} 
& Comerciais & Públicas & Total \\
\hline EMISORAS ACTIVAS & 187 & 162 & 349 \\
\cline { 2 - 4 } & $178 \mathrm{FM}+9$ OM & $152 \mathrm{FM}+10 \mathrm{OM}$ & $330 \mathrm{FM}+19 \mathrm{OM}$ \\
\hline
\end{tabular}

Fonte: elaboración propia.

RADIODIFUSIÓN PÚBLICA (TÁBOAS 2, 3, 4, 5 E 6)

Táboa 2. Emisoras de Radio Nacional de España en Galicia

\begin{tabular}{|c|c|c|c|c|}
\hline & RNE 1 & RNE2 & RNE3 & RNE5 \\
\hline \multicolumn{5}{|l|}{ A CORUÑA } \\
\hline Carballo & 90.1 FM* & 101.4 FM* & $98.8 \mathrm{FM}^{*}$ & 104.4 FM* \\
\hline Monte Xalo & 100.4 FM & $91.6 \mathrm{FM}$ & $94.5 \mathrm{FM}$ & $95.8 \mathrm{FM}$ \\
\hline Muros & $103.3 \mathrm{FM}^{*}$ & $98.4 \mathrm{FM}^{*}$ & 93.4 FM* & 89.4 FM* \\
\hline Santiago & 103.1 FM & 98.1 FM & $99 \mathrm{FM}$ & 93.7 FM \\
\hline Vimianzo & 87.7 FM* & $97.3 \mathrm{FM}^{*}$ & $102.5 \mathrm{FM}^{*}$ & $105.3 \mathrm{FM}^{*}$ \\
\hline Pastoriza & & & & $558 \mathrm{Khz}(\mathrm{OM})$ \\
\hline Mesón do Vento & 639 Khz (OM) & & & \\
\hline \multicolumn{5}{|l|}{ LUGO } \\
\hline Alto do Poio & $89.4 \mathrm{FM}^{*}$ & $92.6 \mathrm{FM}^{*}$ & 105.3 FM* & $95.2 \mathrm{FM}^{*}$ \\
\hline Mondigo & $90.1 \mathrm{FM}^{*}$ & $99.7 \mathrm{FM}^{*}$ & $101.8 \mathrm{FM}^{*}$ & $105 \mathrm{FM}^{*}$ \\
\hline Páramo & 101.7 FM & $88.2 \mathrm{FM}$ & $99.6 \mathrm{FM}$ & 92.8 FM \\
\hline Viveiro & $92 \mathrm{FM}^{*}$ & & & \\
\hline Xistral & $89.5 \mathrm{FM}^{*}$ & 96.3 FM* $^{*}$ & $104.2 \mathrm{FM}^{*}$ & $106.6 \mathrm{FM}^{*}$ \\
\hline Ameixeiras & 801 Khz (OM) & & & 1098 Khz (OM) \\
\hline Monforte & 927 Khz (OM) & & & 88.8 FM \\
\hline \multicolumn{5}{|l|}{ OURENSE } \\
\hline Valdeorras & $94.7 \mathrm{FM}$ & 96.4 FM & $100.3 \mathrm{FM}$ & $104.6 \mathrm{FM}$ \\
\hline Meda & $102.8 \mathrm{FM}$ & $91.2 \mathrm{FM}$ & $94.3 \mathrm{FM}$ & 106.8 FM \\
\hline Ourense & 100.6 FM & $97.2 \mathrm{FM}$ & 99.4 FM & $95.1 \mathrm{FM}$ \\
\hline Ourense & 774 Khz (OM) & & & $1305 \mathrm{Khz}(\mathrm{OM})$ \\
\hline Verín & 90.7 FM & 98.4 FM & $106.4 \mathrm{FM}$ & $94.1 \mathrm{FM}^{*}$ \\
\hline \multicolumn{5}{|l|}{ PONTEVEDRA } \\
\hline Castrove & $102.9 \mathrm{FM}^{*}$ & $88.3 \mathrm{FM}^{*}$ & $94.6 \mathrm{FM}^{*}$ & 104.3 FM \\
\hline Domaio & $90.1 \mathrm{FM}$ & $92.1 \mathrm{FM}$ & 97.4 FM & \\
\hline Marín & 855 Khz (OM) & & & \\
\hline Pontevedra & $531 \mathrm{Khz}(\mathrm{OM})$ & & & 1413Khz (OM) \\
\hline Vigo & & & & $96 \mathrm{FM}$ \\
\hline
\end{tabular}

* Emisoras de nova creación. 
Táboa 3. Emisoras / Frecuencias da Radio Galega

Estación

FM

A CORUÑA

Cariño-Ortigueira

87.6

Carballo

88.5

Santiago

96.2

A Coruña

104.8

Ferro

103.9

Cee

104.4

Vimianzo

104.6

Muros

106.6

Noia

90.3

LUGO

Navia de Suarna 91.1

Vilalba 94.1

Lugo 98.3

Folgoso do Courel 100.4

Pedrafita 102.4

Lourenzá-Foz 103.3

Viveiro $\quad 103.5$

Sarria 103.7

A Pontenova $\quad 104.5$

Ribadeo 95.9

Xove-Burela

95.9

OURENSE

\begin{tabular}{lc}
\hline Verín & 88.5 \\
\hline Lobios & 92.7 \\
\hline Ourense & 105.5 \\
\hline O Barco & 101.2 \\
\hline Montederramo-Meda & 104.8 \\
\hline Viana do Bolo & 105.2 \\
\hline PONTEVEDRA & \\
\hline A Guarda & 91.0 \\
\hline A Curota & 92.4 \\
\hline A Cañiza & 93.5 \\
\hline Pontevedra & 94.7 \\
\hline Vigo & 95.1 \\
\hline Tui & 96.0 \\
\hline Cuntis-Caldas & 100.9 \\
\hline Redondela-Bueu & 102.3 \\
\hline Lalín & 104.4 \\
\hline Nigrán & $99.7^{*}$ \\
\hline
\end{tabular}

* Emisora de nova creación. 
Táboa 4. Emisoras/ Frecuencias da Radio Galega Música

\begin{tabular}{lc} 
Estación & FM \\
\hline Santiago & 104.2 \\
\hline Ferrol & 106.3 \\
\hline A Coruña & 92.1 \\
\hline A Cova (Lugo) & 96.6 \\
\hline Ourense & 95.6 \\
\hline Lugo & 106.2 \\
\hline Pontevedra & 101.4 \\
\hline Xiabre & 88.0 \\
\hline Vigo & $90.8^{*}$ \\
\hline Xistral (Lugo) & $100.2^{*}$ \\
\hline Páramo (Lugo) & $100.6^{*}$ \\
\hline
\end{tabular}

* Emisoras de nova creación.

Táboa 5. Emisoras municipais galegas activas en 2013-2015

\begin{tabular}{|c|c|c|c|}
\hline A CORUÑA & LUGO & OURENSE & PONTEVEDRA \\
\hline Ames & Quiroga* & Allariz* & A Estrada* \\
\hline Arzúa* & Foz & & Lalín* \\
\hline Betanzos* & Xove & & Tui* \\
\hline Boiro* & Burela & & Redondela* \\
\hline Boqueixón* & Monforte* & & \\
\hline \multicolumn{4}{|l|}{ Cerceda* } \\
\hline \multicolumn{4}{|l|}{ Culleredo* } \\
\hline \multicolumn{4}{|l|}{ Eume* } \\
\hline \multicolumn{4}{|l|}{ Fene* } \\
\hline \multicolumn{4}{|l|}{ Melide* } \\
\hline \multicolumn{4}{|l|}{ Oleiros* } \\
\hline \multicolumn{4}{|l|}{ Ordes* } \\
\hline \multicolumn{4}{|l|}{ Sada* } \\
\hline \multicolumn{4}{|l|}{ Carral } \\
\hline Negreira* & & & \\
\hline
\end{tabular}

* Emisoras integradas en EMUGA. 
Táboa 6. Emisoras de EMUGA que emiten conxuntamente a programacion «Radiofusión»

\begin{tabular}{llll} 
A CORUÑA & LUGO & OURENSE & PONTEVEDRA \\
\hline Boiro & Burela & Allariz & Redondela \\
\hline Arzúa & Monforte & \\
\hline Culleredo & & \\
\hline Eume-As Pontes & & \\
\hline Fene & & \\
\hline Ordes & \\
\hline Negreira & \\
\hline Sada & \\
\hline Cerceda & \\
\hline
\end{tabular}

Táboa 7. Emisora Cultural

\begin{tabular}{ll}
\hline Radio ECCA & Pontevedra-Vigo
\end{tabular}

RADIODIFUSIÓN COMERCIAL (TÁBOAS 8, 9, 10, 11,12,13,14 E 15)

Táboa 8. Emisoras de Unión Radio (Grupo Prisa)

\begin{tabular}{|c|c|c|c|}
\hline A CORUÑA & LUGO & OURENSE & PONTEVEDRA \\
\hline Radio Galicia & Radio Lugo & Radio Ourense & R. Pontevedra \\
\hline Santiago (SER) & (SER) & (SER) & (SER) \\
\hline $873 \mathrm{OM} / 95.2 \mathrm{FM}$ & 1.2870M/95.6 FM & $1.584 \mathrm{OM}$ & $1.116 \mathrm{OM} / 98.7 \mathrm{FM}$ \\
\hline $\begin{array}{l}\text { Radio Coruña } \\
\text { (SER) }\end{array}$ & $\begin{array}{l}\text { Radio Mariña } \\
\text { (SER) }\end{array}$ & $\begin{array}{l}\text { Radio Limia } \\
\text { (SER) }\end{array}$ & $\begin{array}{l}\text { Radio Arosa } \\
\text { (SER) }\end{array}$ \\
\hline $1.080 \mathrm{OM} / 93.4 \mathrm{FM}$ & $90.2 \mathrm{FM}$ & $89.1 \mathrm{FM}$ & $95.6 \mathrm{FM}$ \\
\hline Nordés-Vimianzo & 40 P. Lugo & Radio Ribeiro & Radio Vigo \\
\hline (SER) & $91.8 \mathrm{FM}$ & (SER) & (SER) \\
\hline $92.2 \mathrm{FM}$ & & $96.6 \mathrm{FM}$ & $1.026 \mathrm{OM} / 100.6 \mathrm{FM}$ \\
\hline 40 P. Santiago & 40 P. A Mariña & 40 Principales & 40 Principales \\
\hline \multirow[t]{2}{*}{$90.6 \mathrm{FM}$} & $94.8 \mathrm{FM}$ & Ourense & Pontevedra \\
\hline & & $87.6 \mathrm{FM}$ & $89.1 \mathrm{FM}$ \\
\hline 40 P. Coruña & Cadena Dial & Dial & 40 Principales \\
\hline \multirow[t]{2}{*}{$91.0 \mathrm{FM}$} & Lugo & Ourense & Vigo \\
\hline & $90.8 \mathrm{FM}$ & 96.1 FM & $99.4 \mathrm{FM}$ \\
\hline M80 Coruña & Cadena Dial & & Dial \\
\hline \multirow[t]{2}{*}{$97.6 \mathrm{FM}$} & \multirow{2}{*}{\multicolumn{2}{|c|}{ Mariña 94.8 FM }} & Pontevedra \\
\hline & & & $91.4 \mathrm{FM}$ \\
\hline Dial Rías Altas & Radio Faro & & Dial Vigo \\
\hline $98.5 \mathrm{FM}$ & $\begin{array}{l}\text { Ser-Chantada } \\
\text { 93.5 FM }\end{array}$ & & $96.9 \mathrm{FM}$ \\
\hline
\end{tabular}




\begin{tabular}{|c|c|c|}
\hline A CORUÑA & OURENSE & PONTEVEDRA \\
\hline M80 Coruña & Radio Principal & Radio Máxima \\
\hline \multirow[t]{2}{*}{ 97.6 FM } & Monforte-Ser & Pontevedra \\
\hline & 97.0 FM & $97.8 \mathrm{FM}$ \\
\hline Bergantiños-Ser & Radio Principal & Radio Máxima \\
\hline \multirow[t]{5}{*}{ 95.4 FM } & Vilalba-Ser & Vigo 104.7 FM \\
\hline & 87.7 FM & M80 Pontevedra \\
\hline & & 97.6 FM \\
\hline & & M80 Vigo \\
\hline & & 101.2 FM \\
\hline
\end{tabular}

Fonte: Guía da Comunicación, Xunta de Galicia.

Táboa 9. Emisoras Cadena Cope/ Cadena 100

\begin{tabular}{|c|c|c|c|}
\hline A CORUÑA & LUGO & OURENSE & PONTEVEDRA \\
\hline Cope Ferrol & Cope Lugo & Cope Ourense & Cope Vigo \\
\hline $873 \mathrm{OM}$ & $1.224 \mathrm{OM}$ & $1.143 \mathrm{OM}$ & $900 \mathrm{OM}$ \\
\hline Cope Coruña & Cope Ribadeo & Cope Verín & Cope Vilagarcía \\
\hline 96.9 FM & 93.6 FM & $91.6 \mathrm{FM}$ & 106.4 FM \\
\hline Cope Santiago & Cope Becerreá & Cope Ribadavia & Pontevedra Cope-Deza \\
\hline 97.1 FM & $96.6 \mathrm{FM}$ & $88.9 \mathrm{FM}$ & 106.6 FM \\
\hline Cope Cariño & Cope Vilalba & Cope O Barco & Cadena 100 A Estrada \\
\hline $97.9 \mathrm{FM}$ & 101.2 FM & $89.2 \mathrm{FM}$ & 88.4 FM \\
\hline Cope Carballo & Cope Costa Ribadeo & Cadena 100 Ourense & Cadena 100 R. Baixas \\
\hline 101.9 FM & 106.0 FM & 92.4 FM & 89.6 FM \\
\hline Cope Noia & Cope Lugo & Cope Carballiño & \\
\hline $105.5 \mathrm{FM}$ & 88.9 FM & 91.9 FM & \\
\hline Cadena 100 Coruña & Cadena 100 Lugo & & \\
\hline 88.7 FM & 90.0 FM & & \\
\hline Cadena 100 Santiago & Cadena 100 Ribadeo & & \\
\hline 88.4 FM & 106.0 FM & & \\
\hline
\end{tabular}

Fonte: Guía da Comunicación, Xunta de Galicia. 
Táboa 10. Emisoras de Radiovoz en 2012

\begin{tabular}{lr} 
A Coruña & $92.6 \mathrm{FM}$ \\
\hline Bergantiños & $99.8 \mathrm{FM}$ \\
\hline Compostela & $106.1 \mathrm{FM}$ \\
\hline Ferrol & $105.4 \mathrm{FM}$ \\
\hline Lugo & $105.6 \mathrm{FM}$ \\
\hline Ourense & $101.4 \mathrm{FM}$ \\
\hline Pontevedra & $93.1 \mathrm{FM}$ \\
\hline Vigo & $103.8 \mathrm{FM}$
\end{tabular}

Fonte: Guía da Comunicación, Xunta de Galicia.

Táboa 11. Emisoras de Onda Cero en 2012

\begin{tabular}{lr} 
A Coruña & $102.7 \mathrm{FM}$ \\
\hline Ferrol & $99.3 \mathrm{FM}$ \\
\hline Muros & $101.5 \mathrm{FM}$ \\
\hline Porto do Son & $88.8 \mathrm{FM}$ \\
\hline Santiago & $104.6 \mathrm{FM}$ \\
\hline Vigo & $94.9 \mathrm{FM}$ \\
\hline A Mariña & $102.3 \mathrm{FM}$ \\
\hline Monforte & $90.4 \mathrm{FM}$ \\
\hline Sarria & $98.2 \mathrm{FM}$ \\
\hline Ourense & $98.8 \mathrm{FM}$ \\
\hline Verín & $95.8 \mathrm{FM}$ \\
\hline O Barco & $97.9 \mathrm{FM}$ \\
\hline O Carballiño & $97.9 \mathrm{FM}$ \\
\hline O Porriño & $92.6 \mathrm{FM}$ \\
\hline Lalín & $94.2 \mathrm{FM}$ \\
\hline Pontevedra & $106.9 \mathrm{FM}$ \\
\hline Valmiñor & $100.3 \mathrm{FM}$ \\
\hline Maceira & $89.9 \mathrm{FM}$
\end{tabular}

Fonte: Guía da Comunicación, Xunta de Galicia.

Táboa 12. Emisoras de Europa FM en 2006

\begin{tabular}{ll} 
Santiago & $90.9 \mathrm{FM}$ \\
\hline Ferrol & $95.0 \mathrm{FM}$ \\
\hline Lalín & $98.6 \mathrm{FM}$ \\
\hline O Porriño & $97.1 \mathrm{FM}$ \\
\hline Ourense & $93.3 \mathrm{FM}$ \\
\hline
\end{tabular}

Fonte: Guía da Comunicación, Xunta de Galicia. 
Táboa 13. Emisoras Cadena Ibérica/Radio Líder*

\begin{tabular}{|c|c|c|c|}
\hline A CORUÑA & LUGO & OURENSE & PONTEVEDRA \\
\hline Santiago & Carballiño & Lemos & Louriña \\
\hline 101.9 FM & 107.4 FM & 107.2 & 90.8 FM \\
\hline A Coruña & & & Morrazo \\
\hline 105.0 FM & & & 105.4 FM \\
\hline Touro & & & Lalín \\
\hline $91.8 \mathrm{FM}$ & & & 106.8 FM \\
\hline Xallas & & & Salnés \\
\hline 107.0 FM & & & 107.9 FM \\
\hline Val do Dubra & & & Moaña \\
\hline 107.2 FM & & & 90.8 FM \\
\hline \multicolumn{4}{|l|}{ Boqueixón } \\
\hline \multicolumn{4}{|l|}{ 107.2 FM } \\
\hline \multicolumn{4}{|l|}{ Arzúa } \\
\hline \multicolumn{4}{|l|}{ 107.4 FM } \\
\hline \multicolumn{4}{|l|}{ Noia } \\
\hline \multicolumn{4}{|l|}{$107.6 \mathrm{FM}$} \\
\hline \multicolumn{4}{|l|}{ Melide } \\
\hline \multicolumn{4}{|l|}{$107.5 \mathrm{FM}$} \\
\hline \multicolumn{4}{|l|}{ Santa Comba } \\
\hline \multicolumn{4}{|l|}{ 107.6 FM } \\
\hline \multicolumn{4}{|l|}{ Costa da Morte } \\
\hline 107.9 FM & & & \\
\hline
\end{tabular}

*Estas emisoras irregulares xa non aparecen na Guía da Comunicación da Xunta, 2012.

Táboa 14. Emisoras de Punto Radio

\begin{tabular}{lr} 
A Coruña & $90.3 \mathrm{FM}$ \\
\hline Santiago & $100.2 \mathrm{FM}$ \\
\hline Pontevedra & $99.4 \mathrm{FM}$ \\
\hline Vigo & $106.7 \mathrm{FM}$ \\
\hline Lugo & $88.9 \mathrm{FM}$ \\
\hline Ourense & $89.9 \mathrm{FM}$ \\
\hline Ferrol & $101.3 \mathrm{FM}$ \\
\hline
\end{tabular}

Fonte: Guía da Comunicación, Xunta de Galicia. 
Táboa 15. Emisoras de Editorial Compostela S.A.

\begin{tabular}{lr} 
Emisora & Frecuencia \\
\hline Radio Obradoiro (Santiago) & $102.1 \mathrm{FM}$ \\
\hline Radio Arzúa & $90.2 \mathrm{FM}$ \\
\hline
\end{tabular}

Táboa 16. Audiencia da radio en Galicia

\begin{tabular}{llll}
$\begin{array}{l}\text { TOTAL* } \\
\text { Maiores de } 14\end{array}$ & Total Oíntes & Radio Convencional & Radio Temática \\
\hline 2.445000 & 1.443000 & 810000 & 827000 \\
\hline
\end{tabular}

* Datos do acumulado abril de 2011 a marzo de 2012 do Estudio General de Medios.

Audiencia da radio convencional en Galicia

\begin{tabular}{ll}
$\begin{array}{l}\text { Total universo Galicia* } \\
\mathbf{2 4 4 5} \mathbf{0 0 0}\end{array}$ & $\begin{array}{l}\text { Oíntes radio convencional } \\
\mathbf{8 1 0 0 0 0}\end{array}$ \\
\hline SER & 310000 \\
\hline RADIO & \\
\hline GALEGA & 157000 \\
\hline ONDA & 148000 \\
\hline CERO & 133000 \\
\hline COPE & 96000 \\
\hline RNE1 & Sen datos \\
\hline RADIOVOZ & Sen datos \\
\hline PUNTO RADIO &
\end{tabular}

* Datos do acumulado abril de 2011 a marzo de 2012 do Estudio General de Medios.

O tempo de escoita media foi de 111 minutos fronte á media do Estado, de 117 minutos. 
Audiencia da radio temática en Galicia

Total universo Galicia* Oíntes radio temática

2445000 827000

40 Principales

243000

Dial 102000

Cadena $100 \quad 190000$

Europa FM 119000

Kiss FM 46000

Máxima FM 27000

R. Marca 45000

$\mathrm{M} 80 \quad 44000$

RNE 3

25000

\begin{tabular}{lr}
\hline RNE 2 & 7000 \\
\hline RNE5 & 29000 \\
\hline
\end{tabular}

* Datos do acumulado abril de 2011 a marzo de 2012 do Estudio General de Medios.

O tempo de escoita media foi de 105 minutos fronte á media do Estado, de 111 minutos. 


\section{REFERENCIAS BIBLIOGRÁFICAS}

BOE (2010): Ley 7/2010, de 31 de marzo, General de la Comunicación Audiovisual.

BOE (2009): Ley 8/2009, de 28 de agosto, de financiación de la Corporación de Radio y Televisión Española.

BOE (2006): Ley 17/2006, de 5 de junio, de la radio y la televisión de titularidad estatal.

BONET, M. (1995): La Radio Española en el contexto de los grupos de comunicación, Barcelona, UAB.

Bustamante, E. (2012): Radiotelevisión pública en España: por una financiación pública estable, Periodista.es. Recuperado de http://periodistas-es.com.

Chomón, J. M. (2011): Evolución y transformación de Radio 5 Todo Noticias, Madrid, Fragua.

FRANQUET, Rosa (2008): La radio digital en España: incertidumbres tecnológicas y amenazas al pluralismo, Madrid, Fundación Alternativas.

Ortiz Sobrino, M. Á. (2012): «Evolución del modelo de financiación de Radio 5», ICONO, 14. Revista de Comunicación y Tecnologías Emergentes, 10(3), 383-402. Recuperado de www.icono14.net.

Pousa, X. R. / H. A. Yaguana (2013): La Radio, un medio en evolución, Salamanca, Comunicación Social. 



\section{SITUACIÓN DO MEDIO TELEVISIVO EN GALICIA (2012-2014): CONTEXTO, AUDIENCIA, INVESTIMENTO PUBLICITARIO, USO DO GALEGO E TENDENCIASS}

Silvia García Mirón

Mónica Valderrama Santomé Universidade de Vigo

Doi:10.17075/aceg.2016.004 



\section{PRESENTACIÓN}

Tras varios anos de transformación do modelo televisivo no contexto español mediante a integración do sistema dixital e das novas fórmulas de distribución e promoción de contidos televisivos a través de Internet así como dun reaxuste do mercado, no ano 2012 observouse un forte incremento do consumo televisivo no país (non tanto na comunidade autónoma galega) xunto ao inicio da concentración do sector, que será máis significativa en 2013, ata que se advertirá a recuperación do investimento publicitario - despois de anos de recesión- no ano 2014. Estes tres últimos anos tamén posuirán como principal evento a debilitación da televisión pública, especialmente polo peche de Canal Nou na Comunidade Valenciana en 2013, que se produciu sen que realmente fosen medidas as consecuencias da decisión e que trasladou ao resto de comunidades así como ao panorama nacional as dúbidas sobre o mantemento das emisoras públicas. Este feito, xunto ao fin de 9 canles dixitais, debuxou un novo mapa do sector no bienio 2012-2014, con características diferenciais con respecto a anos previos.

\section{OBXECTO DE ESTUDO E METODOLOXÍA}

O presente texto céntrase en realizar unha análise da actual situación do medio televisivo entre 2012 e 2014 en Galicia, especialmente no tocante a varios ítems de estudo: en primeiro lugar, atendendo aos principais fitos que tiveron lugar en relación con este medio de comunicación; en segundo lugar, a evolución do seu consumo na comunidade así como a audiencia das emisoras autonómicas galegas; en terceiro lugar, ofrecendo os datos máis significativos arredor do investimento publicitario no medio; e, por último, uns apuntamentos sobre o uso do galego por parte das emisoras protagonistas do medio en Galicia.

Para coñecer estes parámetros teremos en conta a oferta da televisión na comunidade galega en termos de cobertura en aberto e de forma gratuíta. Por tanto, observaremos a presenza e comportamento das emisoras autonómicas, tanto públicas (TVG e TVG2) como privadas (V Televisión), así como aquelas de carácter local.

O deseño metodolóxico da investigación, de carácter esencialmente descritivo, configúrase mediante unha fórmula mixta na que se empregan principalmente datos cuantitativos (especialmente os referidos á información do consumo e audiencia televisiva e investimento publicitario ou, mesmo, dos principais xéneros incluídos na programación das emisoras galegas) e tamén outros cualitativos, como aqueles empregados á hora de conseguir información relativa ao actual contexto do medio televisivo en Galicia así coma ao uso da lingua galega por parte das emisoras que operan na comunidade.

\section{CONTEXTO E ANTECEDENTES}

O medio televisivo atópase inmerso nunha revolución que comprende varias perspectivas: a primeira delas de carácter tecnolóxico, a segunda en termos creativos e, por último, dende a revolución do espectador e os cambios no seu 
comportamento ${ }^{1}$. Non obstante, entre todo isto destaca como factor clave que o contido seguirá sendo o elemento diferenciador e motor da industria. Ante os cambios no consumo, o certo é que os contidos televisivos continúan consumíndose en gran medida dende a pantalla tradicional do televisor por parte do espectador máis conservador e pasivo en ocasións; pero vai gañando terreo nos últimos anos o consumo a través das segundas ou terceiras pantallas (ordenadores e dispositivos móbiles) que permiten distintas opcións de visionado (directo, streaming, descarga, etc.) e vénse favorecendo a incorporación de distintas posibilidades de interacción (redes sociais, creación de experiencias transmedia, etc.) empregadas por parte dun usuario máis dinámico, proactivo, ambicioso e devorador de contidos audiovisuais pero, ao mesmo tempo, máis individualista no seu consumo (Barlovento Comunicación 2014).

Á parte desta revolución, no contexto español obsérvanse outros aspectos que condicionan a situación do medio na comunidade galega, sendo o máis influente o económico. A crise económica iniciada no ano 2008 supuxo que os gobernos autonómicos reconsiderasen a importancia do mantemento das emisoras públicas. O seu cuestionamento non reside na súa función, finalidade ou vocación de servizo público, senón no seu custo. Durante este período, as autonómicas están inmersas nun contexto de máxima austeridade e de busca de alternativas para o seu posicionamento no mercado. Porén, polo de agora, desmentiuse calquera idea neste senso por parte da Administración autonómica galega ${ }^{2}$ a pesar de que os datos que amosan os orzamentos da TVG indicaban ata o 2014 esta tendencia, que se rompeu cos orzamentos para o ano $2015^{3}$ cun lixeiro aumento nas achegas por parte da Xunta (cfr. táboa 1). Por outra banda, advertimos que esta inestabilidade dos últimos anos comportou que en 2014 a cota de pantalla das autonómicas rexistrase un mínimo histórico anual (8,0%) (Barlovento Comunicación 2014).

Táboa 1. Evolución do orzamento da TVG

\begin{tabular}{lccc} 
Ano & Orzamento (millóns $€$ ) & Achegas Xunta & Investimento publicitario \\
\hline 2012 & 117,1 & $100,8 \mathrm{~m} €$ & $13,9 \mathrm{~m} €$ \\
\hline 2013 & 103,7 & $93,7 \mathrm{~m} €$ & $10 \mathrm{~m} €$ \\
\hline 2014 & 99,4 & $90 \mathrm{~m} €$ & $9,4 \mathrm{~m} €$ \\
\hline 2015 & 106,8 & $95,8 \mathrm{~m} €$ & $11 \mathrm{~m} €$ \\
\hline
\end{tabular}

Fonte: elaboración propia a partir dos informes corporativos da CRTVG.

Por outra banda, atopámonos nun contexto variable en relación cos propios protagonistas que operan no medio. Deste xeito, no ano 2014 facíase efectiva por parte do Ministerio de Industria a sentenza do Tribunal Supremo que obrigaba ao peche de 9 canles, polo que deixaron de emitir Nitro, Xplora, La Sexta 3, La Siete, Nueve, Intereconomía, MTV, AXN e Teletienda (antiga Marca TV). Este feito xunto ao proceso de fusións (A3-La Sexta e T5-Cuatro) que comporta a creación dun mercado atomizado arredor de tres grupos principais de comunicación no medio (Mediaset, Atresmedia e RTVE) crean a silueta deste novo mapa.

\footnotetext{
${ }^{1}$ Cfr. Entrevista a Paloma Bravo, directora de Márketing e Publicidade da área de vídeo de Telefónica, en «19 expertos nos cuentan como será la televisión del futuro», en http://toyoutome.es/blog/19-expertos-nos-cuentan-como-sera-la-television-del-futuro/35198 (23/03/2015).

2 «Feijóo descarta el cierre de TVG porque tiene unas cuentas saneadas» (6 de novembro de 2013), El País, na súa edición dixital http://ccaa.elpais.com/ccaa/2013/11/06/galicia/1383744888_087180.html (20/02/2015).

3 Tras ter unhas débedas acumuladas dos últimos anos e no seu proceso de conversión nunha corporación, a CRTVG pecharía o ano 2013 con superávit de 0,3 millóns de euros. Cfr. «La CRTVG cerró 2013 con superávit de 0,3 millóns de euros» (30/05/2014), Europa Press, na súa edición online http://www.europapress.es/galicia/noticia-crtvg-cerro-2013-superavit-03-millones-redujo-cero-endeudamiento-bancario-32-millones-2009-20140530144011.html (15/03/2015).
} 
Poñendo o foco no contexto televisivo galego, o actual escenario está protagonizado por dúas canles públicas (TVG e TVG2), unha emisora privada con cobertura autonómica (V Televisión, operada polo Grupo Voz Audiovisual S.L.) e un conxunto de emisoras locais que amosamos na táboa 2.

Táboa 2. Listaxe de emisoras de carácter local en Galicia

\begin{tabular}{ll} 
A Coruña & Pontevedra \\
\hline Correo TV & Canal Rías Baixas \\
\hline Santiago TV & Canal Vía Televisión \\
\hline Eume TV & Correo TV \\
\hline TV Ferrol & Nós TV \\
\hline Canle explotada por Mancumunidade do Salnés & Canle explotada por Editorial La Capital \\
\hline Canle explotada por Editorial Compostelana & Canle explotada por Faro de Vigo \\
\hline Canle explotada por Editoral La Capital & Canle explotada por Lérez Canal 29 \\
\hline Canle explotada por Faro de Vigo & Canle explotada por Multimedia Comun. \\
\hline Canle explotada por La Opinión de La Coruña & Canle explotada por Rías Baixas Produc. \\
\hline Canle explotada por Multimedia Comunicaciones & Canle explotada por TV Pontevedra \\
\hline Canle explotada por Salitre Multimedia & Canle explotada por Utega \\
\hline Canle explotada por Utega & \\
\hline Lugo & Ourense \\
\hline Telelugo & Auria TV \\
\hline Telemiño & Telemiño \\
\hline Televinte & Canle explotada por Faro de Vigo \\
\hline Canle explotada por TV7 Monforte & \\
\hline Canle explotada por Alternativas de Medios Aud. & \\
\hline
\end{tabular}

Fonte: Anuario SGAE das Artes Escénicas, Musicais e Audiovisuais 2014.

Debemos sinalar, así mesmo, nesta epígrafe, que no período de estudo tamén se contaba cunha segunda emisora privada autonómica, Popular TV Galicia (promovida polo Grupo Cope), que resultou unha das dúas licenzas adxudicadas en 2005. Finalizaría as súas emisións o 31 de xullo de 2013 pola imposibilidade económica de manter o proxecto ante o limitado investimento publicitario.

Por último, tamén resulta de relevancia facer mención ao proceso de conversión da TVG en Corporación durante o ano 2014, mediante o que se fusionaron as tres organizacións que conviven na CRTVG coa finalidade de «reflectir sinerxías, aforro e eficiencia» ${ }^{4}$ e flexibilizar a súa xestión.

\section{SITUACIÓN}

Os anos 2012 e 2013 configúranse a nivel nacional como aqueles en que se alcanza o récord absoluto de consumo televisivo: 246 minutos por persoa e día en 2012 e 244 en 2013. Así e todo, Galicia sería nestes dous anos a co-

\footnotetext{
4 «A CRTVG afronta en 2014 a súa conversión en Corporación baixando o seu orzamento ata 99,4 millóns e sen débeda» (05/11/2013), na páxina web corporativa da CRTVG, http://www.crtvg.es/crtvg/crtvgviva/a-crtvg-afronta-en-2014-a-sua-conversion-en-corporacionbaixando-o-seu-orzamento-ata-99-4-millons-e-sen-debeda (25/03/2015).
} 
munidade autónoma española onde se produce o menor consumo de televisión, con 221 minutos, se ben consegue certo aumento no ano 2014 (228 minutos), tal e como se pode apreciar no gráfico 1.

Gráfico 1. Evolución do consumo televisivo por comunidades autónomas (2012-2014)

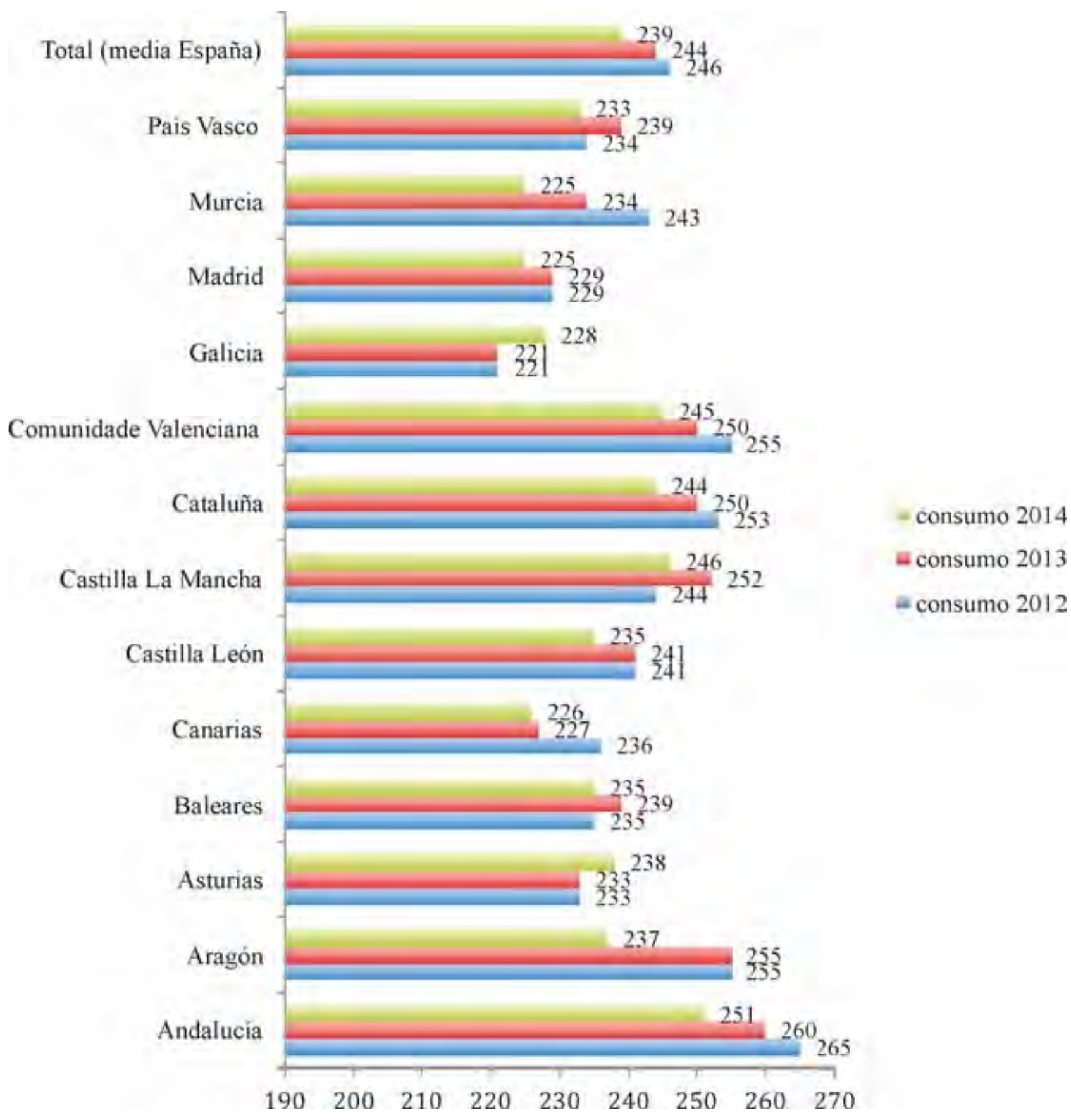

Fonte: elaboración propia a partir de datos de Kantar Media. 
Dende o 2012, a meirande parte das emisoras autonómicas veñen rexistrando mínimos anuais debido á fragmentación. A autonómica que consegue unha maior cota no ano 2012 foi TV3 (14,3 \%), seguida da TVG (11,5\%). Tanto os datos globais das emisoras autonómicas en España como os datos individuais de cada unha das canles que operan en Galicia (TVG, TVG2, V Televisión) amosan este descenso na súa cota de pantalla dende o ano 2011 (táboa 3). A excepción atopámola nas autonómicas privadas, que aumentan o seu consumo no ámbito nacional, cunha media do $0,9 \%$ en 2014.

Táboa 3. Evolución da cota de pantalla das emisoras autonómicas galegas

Emisora

\begin{tabular}{lrrrr} 
& $\mathbf{2 0 1 1}$ & $\mathbf{2 0 1 2}$ & $\mathbf{2 0 1 3}$ & $\mathbf{2 0 1 4}$ \\
\hline TVG & 12,3 & 11,5 & 10,9 & 10,0 \\
\hline TVG2 & 0,9 & 0,9 & 0,9 & 0,8 \\
\hline V Televisión & 0,6 & 0,6 & 0,4 & 0,4 \\
\hline Total autonómicas España & 10,4 & 9,8 & 8,7 & 8,0 \\
\hline Autonómicas privadas & 0,8 & 0,9 & 0,8 & 0,9 \\
\hline
\end{tabular}

Fonte: Barlovento Comunicación a partir de datos de Kantar Media.

Por último, polo que respecta ás televisións locais, os datos do ano 2013 amosan que en Galicia teñen unha audiencia do 12,3 \% (audiencia acumulada nos últimos 30 días segundo o Marco Xeral dos Medios en España, 2014), situándose nunha posición intermedia en relación co resto de comunidades españolas (A Rioxa, cun $44,7 \%$, e Canarias, cun 43,2 \%, serían as que conseguen unha maior presenza, mentres que as de Castela e León, cun 2,0 \%, ou Baleares, cun 2,9\%, son as que acadan os datos máis baixos).

Táboa 4. Perfil do espectador en Galicia e das emisoras públicas galegas

Total TV Galicia

TVG

TVG2

\section{SEXO}

\begin{tabular}{llll}
\hline Home & $47,9 \%$ & $40,8 \%$ & $54,9 \%$ \\
\hline Muller & $52,2 \%$ & $59,2 \%$ & $45,1 \%$
\end{tabular}

IDADE

\begin{tabular}{lrrr}
\hline De 4 a 9 & $1,7 \%$ & $1,0 \%$ & $2,4 \%$ \\
\hline De 10 a 15 & $2,0 \%$ & $0,6 \%$ & $3,3 \%$ \\
\hline De 16 a 19 & $1,2 \%$ & $0,7 \%$ & $1,7 \%$ \\
\hline De 20 a 24 & $2,2 \%$ & $1,9 \%$ & $2,4 \%$ \\
\hline De 25 a 34 & $9,2 \%$ & $7,1 \%$ & $11,2 \%$ \\
\hline De 35 a 44 & $13 \%$ & $9,1 \%$ & $16,8 \%$ \\
\hline De 45 a 54 & $15,3 \%$ & $13,6 \%$ & $16,9 \%$ \\
\hline De 55 a 64 & $17,9 \%$ & $20,3 \%$ & $15,4 \%$ \\
\hline De 65 ou máis & $37,8 \%$ & $45,7 \%$ & $29,9 \%$ \\
\hline CLASE SOCIAL & & & $18,6 \%$ \\
\hline Alta e media-alta & $14,8 \%$ & $10,9 \%$ & $42,6 \%$ \\
\hline Media & $41,8 \%$ & $40,9 \%$ & $38,9 \%$ \\
\hline Media-baixa e baixa & $43,6 \%$ & $48,2 \%$ &
\end{tabular}


Total TV Galicia

TVG

TVG2

\begin{tabular}{lrrr}
\hline HÁBITAT $\left(\mathbf{n}^{\circ}\right.$ hab.) & & & \\
\hline-10000 & $41,1 \%$ & $43,9 \%$ & $38,2 \%$ \\
\hline $10000-50000$ & $30,0 \%$ & $34,3 \%$ & $25,6 \%$ \\
\hline $50000-200000$ & $18,6 \%$ & $13,5 \%$ & $23,7 \%$ \\
\hline $200000-500000$ & $10,4 \%$ & $8,3 \%$ & $12,5 \%$ \\
\hline+500000 & - & - & - \\
\hline
\end{tabular}

Fonte: Anuario SGAE das Artes Escénicas, Musicais e Audiovisuais 2014.

Verbo do perfil do espectador en Galicia (táboa 4), os datos relativos ao ano 2013 indican que o público da televisión na comunidade galega é, en xeral, máis feminino, algo que se representa de igual modo na TVG. 0 espectador desta canle amósase como esencialmente maior, tendo en conta que o 66 \% responde á franxa de 55 anos ou máis e só un 4,9 \% teñen menos 20 anos; de clase baixa ou media-baixa e do ámbito rural. Pola contra, a TVG2 ten un perfil máis novo, máis masculino, de clase media e de ámbito máis urbano que o da TVG.

Táboa 5. Emisións máis vistas en Galicia no último mes (febreiro 2015)

\begin{tabular}{lllrl} 
Rk & Canle & Título & Aud.máx. & Cota \\
\hline 1 & Cuatro & Fútbol. Liga España: Deportivo-Celta & 14,8 & 21,1 \\
\hline 2 & La 1 & Fútbol. Champions League: Manch. City-Barcelona & 12,3 & 25,1 \\
\hline 3 & T5 & Informativos Telecinco 21.00 h & 11,3 & 20,6 \\
\hline 4 & T5 & GH VIP & 9,7 & 29,7 \\
\hline 5 & T5 & Pasapalabra & 9,6 & 25,0 \\
\hline $\mathbf{6}$ & TVG & Telexornal 1 14:30 h & $\mathbf{9 , 6}$ & $\mathbf{2 7 , 3}$ \\
\hline 7 & A3 & Bajo sospecha («El vestido») & 9,2 & 17,7 \\
\hline 8 & La Sexta & Salvados («A lo Espe») & 8,8 & 10,3 \\
\hline 9 & A3 & Velvet («La hora de la verdad») & 8,8 & 15,3 \\
\hline 10 & T5 & GH VIP: El debate & 8,5 & 23,6 \\
\hline 11 & T5 & Levántate Express & 8,4 & 17,6 \\
\hline 12 & T5 & Levántate & 8,4 & 21,4 \\
\hline $\mathbf{1 3}$ & TVG & Telexornal 1 15:00 h & $\mathbf{8 , 2}$ & $\mathbf{1 8 , 0}$ \\
\hline 14 & T5 & GH VIP: Última hora & 8,2 & 14,6 \\
\hline 15 & La 1 & Cuéntame como pasó («Polvo al polvo») & 8,1 & 17,5 \\
\hline 16 & T5 & Hay una cosa que te quiero decir: previo & 8,0 & 17,8 \\
\hline 17 & T5 & GH VIP: Expres & 7,7 & 16,0 \\
\hline $\mathbf{1 8}$ & TVG & Serramoura («Guerra: segunda parte») & $\mathbf{7 , 5}$ & $\mathbf{1 3 , 9}$ \\
\hline 19 & La 1 & Los Goya & 7,5 & 21,0 \\
\hline 20 & La Sexta & El intermedio & 7,3 & 12,9 \\
\hline & & & &
\end{tabular}

Fonte: Kantar Media.

No que atinxe á audiencia, tamén resulta preciso destacar as emisións máis vistas na comunidade galega (táboa 5) en función da audiencia máxima no último mes (febreiro de 2015). Neste ránking só se atopan 3 programas emitidos pola TVG: o Telexornal (en dúas ocasións) e un capítulo da ficción Serramoura. Se observamos os espazos 
coa maior audiencia media da TVG en 2014, acadan o ránking programas de entretemento familiar como Era visto!, Entre familias anda o xogo, Luar ou Larpeiros.

Táboa 6. Emisións más vistas da TVG (xullo-decembro 2014)

\begin{tabular}{|c|c|c|c|c|c|c|c|}
\hline Mes & Emisións & $\begin{array}{l}\text { Aud. } \\
\text { media }\end{array}$ & Share & Mes & Emisións & $\begin{array}{l}\text { Aud. } \\
\text { media }\end{array}$ & Share \\
\hline \multirow{5}{*}{ Xul } & Telexornal 114.30 & 8,3 & 31,0 & \multirow{5}{*}{ Out } & Telexornal 114.30 & 9,4 & 32,1 \\
\hline & Telexornal 115.00 & 6,7 & 23,0 & & Serramoura & 7,0 & 17,0 \\
\hline & Sopa de festa & 5,9 & 15,1 & & Telexornal 115.00 & 7,0 & 21,0 \\
\hline & Fogos do Apóstolo & 5,9 & 18,0 & & Casa Manola & 6,9 & 15,8 \\
\hline & Larpeiros & 5,7 & 16,2 & & Galicia Noticias & 6,4 & 27,2 \\
\hline \multirow{5}{*}{ Ago } & Telexornal 114.30 & 9,4 & 34,3 & \multirow{5}{*}{ Nov } & Telexornal 114.30 & 10,2 & 34,5 \\
\hline & Fútbol DEP.-CEL. & 7,7 & 22,7 & & Serramoura & 6,6 & 14,5 \\
\hline & Telexornal 115.00 & 5,9 & 22,6 & & Galicia Noticias & 6,6 & 30,1 \\
\hline & Galicia Noticias & 5,6 & 28,4 & & Telexornal 115.00 & 6,6 & 23,2 \\
\hline & Sopa de festa & 5,6 & 14,6 & & Telexornal 221.00 & 5,6 & 16,0 \\
\hline \multirow{5}{*}{ Set } & Telexornal 114.30 & 8,8 & 32,4 & \multirow{5}{*}{ Dec } & Telexornal 114.30 & 10,0 & 35,9 \\
\hline & Telexornal 115.00 & 6,9 & 25,2 & & Serramoura & 8,1 & 18,5 \\
\hline & Galicia Noticias & 6,3 & 30,4 & & Telexornal 115.00 & 7,3 & 24,9 \\
\hline & Telexornal 221.00 & 6,0 & 18,5 & & Telexornal 221.00 & 6,9 & 15,6 \\
\hline & Larpeiros & 5,7 & 13,3 & & Larpeiros & 6,7 & 14,5 \\
\hline
\end{tabular}

Fonte: Kantar Media.

En canto ao investimento publicitario, durante o bienio 2012-2014 advertiranse os resultados da crise económica e publicitaria mediante o descenso nas cifras de investimento publicitario na televisión (cun retroceso arredor do $18 \%$ no ano 2012 e outro $10 \%$ en 2013, pasa de 1850 millóns de euros, aproximadamente, a 1650). Tras varios anos de recesión (pola crise e tamén debido ao investimento derivado a outros soportes como Internet), o investimento no medio consegue recuperarse a partir de 2014 (táboa 7).

Táboa 7. Evolución dos ingresos publicitarios das emisoras autonómicas en España

\begin{tabular}{lrrrr} 
& \multicolumn{4}{c}{ Investimento publicitario (millóns de euros) } \\
\hline Emisora & $\mathbf{2 0 1 1}$ & $\mathbf{2 0 1 2}$ & $\mathbf{2 0 1 3}$ & $\mathbf{2 0 1 4}$ \\
\hline TVG/TVG2 (CRTVG) & 12,2 & 13,9 & 7,9 & 7,6 \\
\hline Total autonómicas España & 198,0 & 126,8 & 120,4 & 128,7 \\
\hline Total TV en España & 2237,2 & 1815,3 & 1703,4 & 1890,4 \\
\hline
\end{tabular}

Fonte: Infoadex.

A pesar do descenso nos ingresos publicitarios obtidos entre 2012 e 2013, non sucedeu o mesmo para o número de anuncios emitidos, que aumentarán (cfr. Anuario SGAE das Artes Escénicas, Musicais e Audiovisuais 2014).

Atendendo aos xéneros da programación emitida polas emisoras públicas, observaremos que se mantén a mesma tendencia que se advirte no panorama nacional: a ficción é o xénero que ocupa máis tempo de emisión (Barlovento 
Comunicación 2014), se ben os datos relativos ás autonómicas reflicten unha maior presenza da información (no caso da TVG ocupa o segundo posto) (cfr. táboa 8). Algo ben diferente se observa no caso da TVG2, na que destacan os espazos que se catalogan como miscelánea ou musicais (un dato que sorprende en comparación coas autonómicas ou nacionais).

Táboa 8. Distribución do tempo de emisión das canles públicas galegas por xéneros (2013)

\begin{tabular}{lrr} 
Xéneros & TVG & TVG2 \\
\hline Relixioso & $1,0 \%$ & $0,0 \%$ \\
\hline Cultural & $14,4 \%$ & $8,4 \%$ \\
\hline Información & $\mathbf{2 3 , 5} \%$ & $18,6 \%$ \\
\hline Miscelánea & $19,6 \%$ & $\mathbf{4 0 , 7} \%$ \\
\hline Infoshow & $1,0 \%$ & $0,0 \%$ \\
\hline Concurso & $3,7 \%$ & $0,0 \%$ \\
\hline Deporte & $0,1 \%$ & $16,9 \%$ \\
\hline Toros & $0,0 \%$ & $0,0 \%$ \\
\hline Musical & $11,3 \%$ & $\mathbf{3 0 , 0} \%$ \\
\hline Ficción & $\mathbf{2 5 , 5} \%$ & $15,0 \%$ \\
\hline Programas venda & $0,0 \%$ & $0,0 \%$ \\
\hline Outros & $0,0 \%$ & $0,0 \%$ \\
\hline
\end{tabular}

Fonte: Anuario SGAE das Artes Escénicas, Musicais e Audiovisuais 2014.

\section{USO DA LINGUA GALEGA}

En canto ao uso do galego, observamos que nas públicas si se mantén o seu emprego en todos os programas (mediante un uso directo por parte dos presentadores ou intérpretes, así como mediante un proceso de dobraxe da ficción), salvo por parte dalgún invitado nos programas de produción galega. Desta forma, respéctase o artigo 6 da Lei 9/1984, do 11 de xullo, de creación da Compañía de Radio-Televisión de Galicia, na que se recolle que entre os principios que han de inspirar a programación dos medios xestionados pola Comunidade Autónoma de Galicia se atopa «[...] a promoción e difusión da Cultura e Lingua Galega, así como a defensa da identidade da nacionalidade galega». Esta indicación correspóndese co artigo 4, «Principios inspiradores e alcance», da Lei 9/2011, do 9 de novembro, dos medios públicos de comunicación audiovisual de Galicia, onde tamén se especifica que «a prestación do servizo de comunicación audiovisual por parte da devandita sociedade e as comunicacións que efectúe ao persoal dependente dela no exercicio das súas tarefas será en lingua galega», se ben non se especifica que debe facerse uso da forma do galego normativa e estándar. Neste senso, resulta significativo lembrar que durante este período se produciu unha situación que xerou debate cando a presentadora de A Revista no ano 2012, Lorena Pose, comezou a empregar para a presentación do programa a forma do galego con gheada -que previamente xa fora empregada na produción seriada de ficción Mareas Vivas (Antón Reixa, 1998-2002). Se ben a RAG admite a gheada como oficial, dende a dirección de informativos procedeuse a solicitar que se deixase de empregar esta forma do galego indicando que moita xente non se identificaba con esa variante e o seu uso nos informativos podería influír na credibilidade da canle ${ }^{5}$.

5 «TVG pide a una presentadora que no utilice la gheada» (24/03/2012), en El País na súa edición online http://ccaa.elpais.com/ ccaa/2012/03/24/galicia/1332614868_924474.html (25/03/2015). 
Por outra banda, de acordo co Informe de Servizo Público do grupo CRTVG para o ano 2013, incorpórase unha epígrafe relativa á normalización lingüística, na que se indica que se conta cun equipo de lingüistas orientado a conseguir unha maior calidade no uso da lingua.

No que atinxe á emisora privada, $\vee$ Televisión, podemos advertir que inclúe algúns contidos en español e outros en galego. Polo que podemos observar na información da súa páxina web corporativa (http://www.vtelevision.es), actualmente a gran maioría dos programas en emisión empregan o castelán para a súa realización. Daqueles espazos en emisión, a excepción son De bares (emprego do galego e castelán indistintamente) e Soño con Ciencia ou Ata a cociña! (realizados en galego).

\section{TENDENCIAS PARA O FUTURO}

A pesar da incerteza e dos cambios constantes aos que se está enfrontando o sector televisivo, semella que o futuro se achega con matices positivos, tal e como se amosa cos datos relativos ao investimento publicitario e polos propios datos de consumo (aos que nos debemos achegar non só dende o consumo propiamente televisivo, senón dende o punto de vista de consumo audiovisual, que se está vendo incrementado no público máis novo a través das segundas e terceiras pantallas).

Neste contexto de cambio e de transformación do comportamento do espectador no consumo audiovisual, as emisoras autonómicas, tanto as públicas como as privadas, é necesario que continúen transformándose e avanzando cara á contorna dixital. As actuacións deben formularse: en primeiro lugar, ofertando novas formas de consumir os seus contidos centradas no «anytime, anywhere», xa que o protagonista no presente e futuro inmediato será o espectador/consumidor; en segundo lugar, centrando a atención nos contidos, que deben estar creados para resultar atraentes na oferta a través da pantalla do televisor e con posibilidades de visionado online (tanto en directo como en diferido) e contemplando innovadoras posibilidades de investimento publicitario; e, en terceiro lugar, deben integrarse de forma estratéxica nas redes sociais e tratar de empregar fórmulas de participación e interacción con este novo espectador máis activo.

Con todo, observamos unha cuarta proposta de actuación estratéxica en relación coa principal preocupación que deben posuír as emisoras autonómicas públicas e que reside no cuestionamento que se está facendo nos últimos anos sobre o seu papel na sociedade. Para isto é preciso levar a cabo un proceso explicativo e de concienciación da súa función de servizo público que debe ficar clara dende a formulación dos seus contidos programáticos, diferenciais do resto de emisoras comerciais, e incentivando a promoción dos elementos culturais, lingüísticos e identitarios da comunidade galega. 


\section{REFERENCIAS BIBLIOGRÁFICAS}

AIMC (2014): Marco Xeral dos Medios de Comunicación 2014.

BaRlovento Comunicación (2014): Análisis televisivo 2014. Consulta realizada o 22/03/2015 en http://www. barloventocomunicación.es.

BARLovento Comunicación (2013): Análisis televisivo 2013. Consulta realizada o 22/03/2015 en http://www.barloventocomunicación.es.

BARLovento Comunicación (2012): Análisis televisivo 2012. Consulta realizada o 22/03/2015 en http://www.barloventocomunicación.es.

EGEDA (2013): Panorama Audiovisual 2012, Madrid, Entidad de Gestión de los Derechos de los Productores Audiovisuales.

FAndiÑo, X. / A. DAFonte (2007): «A televisión en Galicia: actualidade e futuro», en X. López García (coord.), A comunicación en Galicia 2007, Santiago de Compostela, Consello da Cultura Galega.

INFOADEX (2015): Estudio Infoadex de la inversión publicitaria en España 2014. Resumen. Consulta realizada o 25/03/2015 en http://www.infoadex.es.

INFOADEX (2014): Estudio Infoadex de la inversión publicitaria en España 2013. Resumen. Consulta realizada o 25/03/2015 en http://www.infoadex.es.

IINFOADEX (2013): Estudio Infoadex de la inversión publicitaria en España 2012. Resumen. Consulta realizada o 25/03/2015 en http://www.infoadex.es.

INFOADEX (2012): Estudio Infoadex de la inversión publicitaria en España 2011. Resumen. Consulta realizada o 25/03/2015 en http://www.infoadex.es.

Kantar Media España: Boletíns mensuais de estudos das audiencias. Consulta realizada o 20/02/2015 en www.kantarmedia.es. SGAE (2015): Anuario SGAE das Artes Escénicas, Musicais e Audiovisuais 2014. Consulta realizada o 05/03/2015 en http:// www.anuariossgae.com/anuario2014/anuariopdfs/07_TV.pdf.

ZENITH (2014): Los medios en España y Portugal 2014, Madrid, Zenith.

ZENITH (2013): Los medios en España y Portugal 2013, Madrid, Zenith. 


\section{O CINE: UN SECTOR CONVULSO}

\section{Miguel Anxo Fernández}

Universidade de Vigo

Doi:10.17075/aceg.2016.005 

No informe anterior ${ }^{1}$ xa faciamos referencia á unha cuestión metodolóxica capital para unha análise do sector audiovisual en Galicia: a escaseza de fontes co rigor necesario para trazar unha radiografía de mínimos arredor da materia, a pesar da súa condición de industria cultural, polo tanto sometida a cifras e parámetros que deberían ser de dominio público. As circunstancias non mudaron desde aquela. Entre as consecuencias da crise económica, en particular no período aquí analizado, está a dun sector deprimido no que as produtoras que lograron manter a persiana aberta, evitando desaparecer do rexistro de empresas, optaron por centrar a súa estratexia de supervivencia na procura á desesperada dos recursos públicos (como é natural esta afirmación admite excepcións), a través das convocatorias anuais de estímulo á produción audiovisual (cadro 1) promovidas pola Axencia Galega das Industrias Culturais $(A G A D I C)^{2}$ ou na poxa polos recursos económicos que Televisión de Galicia destina para a produción allea. No sector audiovisual, que ten como os piares básicos da xeración de negocio o da produción (coas súas complexidades) e mais o da difusión e explotación (coas súas variantes de distribución, exhibición en salas, home cinema e Rede), escasean os datos que permitan unha ollada, cando menos, razoable por aproximada.

No tocante á produción, polo seu vínculo directo co contorno empresarial e profesional, existen os volumes bimensuais Papeis da Academia Galega do Audiovisual³, que desde o curso 2006/2007 promove a institución que lles dá nome, e as memorias anuais da Asociación Galega de Produtoras Independentes (AGAPI) ${ }^{4}$, quedando só o recurso das fontes xornalísticas a través dos seus diferentes soportes, xa que o institucional Observatorio Audiovisual Galego ${ }^{5}$ mantense inactivo desde 2010, igual que a web do outro colectivo profesional, a Asociación de Empresas Galegas do Audiovisual (AEGA) ${ }^{6}$. Cómpre engadir, a maiores, a achega da citada AGADIC, o organismo que desde 2012 asume as competencias de política audiovisual da Xunta de Galicia e que recolle no seu portal ${ }^{7}$ non só as novas derivadas da xestión propia, senón tamén outras vinculadas ao sector privado, incluíndo o acceso virtual á oferta do Centro Galego de Artes da Imaxe (CGAI)-Filmoteca de Galicia, por estar agora incorporado administrativamente ao seu organigrama.

1 Xosé López García / Manuel Rivas Barrós / Rosa Aneiros Díaz (coords.) (2013): A comunicación en Galicia 2013, Santiago de Compostela, Consello da Cultura Galega, 119-131.

20 miúdo das correspondentes á produción de longametraxes en 2013 poden consultarse en http://www.agadic.info/gfx/axudas/ axudas_prod_av resolucion_13.pdf e as do ano seguinte en http://www.agadic.info/gfx/axudas/axudas_producion_audiovisual_resolucion $\overline{14}$.pdf.

3 Dispoñible toda a serie en https:/www.academiagalegadoaudiovisual.com/publicacions/page/2l. Constitúen en si mesmo unha panorámica interesante do sector, dado que recollen opinións, estatísticas, novas, premios, balances. Con todo, o seu carácter achégase máis á reflexión que a unha vocación clara de balance anual global. Cómpre ter en conta que a Academia é un club privado de adscricións voluntarias e non engloba a todos os profesionais do sector.

4 http://www.agapi.org/v2/portada.php. A súa web amósase moi activa, recollendo novas do audiovisual galego en xeral, con especial atención ás xeradas polos seus asociados, ademais de convocatorias, premios... Agrupa 18 empresas, que non son a totalidade do sector, aínda que entre elas está a de maior rendibilidade por venda de billetes nos últimos anos pola súa participación en filmes como El niño, que en 2014 deixou uns ingresos brutos en salas de 16175 804,74, desde a súa estrea o 28 de agosto de 2014 (Consultado o 3 de febreiro de 2015 en https://www.mecd.gob.es/bbddpeliculas/buscarDetallePeliculas.do?brscgi_DOCN=000046857\&brscgi_BCSID $=92$ dbeaea\&language $=$ es\&prev_layout=bbddpeliculasResultados\&layout=bbddpeliculasDetalle).

5 En www.observatorioaudiovisual.org, que non actualiza datos desde 2010, figura como «servizo da Secretaría Xeral de Medios da Presidencia da Xunta de Galicia».

6 http://www.aega.tv/ (Consultada o 17 de febreiro de 2015).

7 http://www.agadic.info/. 
Igualmente, o eido da difusión caracterízase por unha desigual opacidade, aínda que a existencia do control de billetes vendidos por parte do Ministerio de Educación, Cultura y Deporte permite, polo menos, que se poida ter información puntual e rigorosa do resultado económico da explotación dos filmes galegos en salas, así como do número destas en varios parámetros (por provincia, por comunidade...) a través do seu sitio web ${ }^{8}$. 0 escurantismo instálase de cheo na explotación dos filmes para o home cinema e mais no servizo de descarga legal de filmes online en streaming (non se difunden publicamente datos do número de copias vendidas e de descargas), modalidades ás que xa se incorporou o produto galego con asiduidade. Por iso, radiografar o sector audiovisual segue a ser tarefa titánica con moito de especulativa.

\section{MÁIS CINE PROPIO NAS PANTALLAS PROPIAS}

Así e todo, é ben certo que se poden facilitar algúns datos obxectivos do bienio 2013-2014, que, cando menos, permiten asegurar que a normalización do sector xa non é tarefa pendente, que o talento agroma, que hai resultados parciais que invitan ao optimismo, sobre todo na acollida popular e tamén crítica a algúns filmes, previo o seu paso polas pantallas. Con todo, e á vista do cadro 2, hai que facer un alto para precisar que este período se abriu mantendo os atrancos de acceso ao circuíto exhibidor comercial, dado que o cine galego non se afasta das dificultades do español e do pertencente a terceiros países, á marxe da predominante industria estadounidense. Por esa razón, o extraordinario éxito económico de El Niño, que foi o segundo filme español máis visto do ano ${ }^{9}$, participado por Vaca Films Studio, empequenece en moito a salientable acollida de El club de los incomprendidos, coproducida por Bambú Films, e ao tempo reduce á mínima expresión o resultado de $A$ esmorga, promovida desde Vía Láctea Films, pero que, ao estrearse só en versión galega en Galicia (certamente de modo masivo), fai que os case 50000 espectadores acadados desde a súa estrea sexan unha moi considerable cifra. Da mesma maneira, cómpre matizar que o limitado resultado de boa parte dos filmes se debe a unha estrea moi restrinxida, mesmo nalgún caso en sesións limitadas.

Precisamente, no eido da exhibición aconteceron feitos de interese, en parte encamiñados a crear ventás abertas ao cine alleo contra do abafante made in Hollywood, tanto desde a banda institucional como da iniciativa privada en canto a difusión do produto propio en salas. Desde finais de 2014, a AGADIC promove o programa Cinemas de Galicia, «unha rede de salas públicas para a exhibición cinematográfica impulsada [...] coa finalidade de incrementar tanto o número de pantallas da Comunidade, como as opcións de distribución dos filmes galegos máis recentes», engadindo a súa pretensión «de facilitarlle ao público galego a oportunidade de gozar en pantalla grande dunha escolma de filmes que, malia a súa contrastada calidade, non son doados de atopar nos circuítos comerciais» ${ }^{10}$. Dese modo, xa a comezos de 2015, vilas carentes de salas comerciais, como son 0 Carballiño, Verín, Sanxenxo, Redondela, Ortigueira, As Pontes e Foz, contribúen á visibilidade do outro cine, o galego incluído, ás que se sumarán outras vilas no futuro. A maiores, en marzo de 2015, despois dun prolongado tempo de maduración neste bienio, abriuse en Compostela o espazo Numax, que oferta unha sala especializada en cine de autor en versión orixinal con lendas, oferta tamén asumida polas cinco pantallas dos Multicines Norte, en Vigo. Convén engadir, a maiores, a total reconversión dixital do parque exhibidor galego, incluídas as salas chamadas periféricas polo seu asentamento en vilas. Desa maneira, Galicia dispuña de 170 pantallas en 2014, pouco máis do $4 \%$ das 3908 existentes en España, cunha perda de 14 con relación ás existentes un ano antes (cadro 3). En canto á asistencia

8 http://www.mecd.gob.es/cultura-mecd/areas cultura/cine/inicio.html;jsessionid=87EFEE0418B48F00D5E4C0D8E1F91E67.

9 Ocho apellidos vascos foi a máis vista de 2014, acadou o récord de toda a historia do cine español con 9346289 espectadores e unha recadación bruta de $55163074,90 €$.

10 http://www.agadic.info/cinemasdegalicia. 
ás salas por parte dos espectadores galegos, a proporción sitúase por debaixo do 4 \% durante o bienio (cadro 4), apenas mellorado en 2014, en boa parte polo récord histórico de recadación acadado polo filme Ocho apellidos vascos, de Emilio Martínez Lázaro ${ }^{11}$.

\section{UNHA DIFUSIÓN PLURALIZADA}

Da mesma maneira, no aspecto da difusión, á parte das pantallas, hai outras canles que tamén axudan á visibilidade do cine galego, sobre todo as mostras e festivais de periodicidade anual, que, con desigual incidencia pero sen abeirar o produto propio, poñen o foco no audiovisual do país integrándoo nas súas programacións, contribuíndo igualmente á promoción dos seus autores. Velaí Cans (O Porriño), Play-Doc (Tui), Cineuropa (Santiago de Compostela), Curtocircuito (Santiago de Compostela), s8 Mostra de Cine Periférico (A Coruña), Ourense Film Festival (Ourense), Festival Amal (Santiago de Compostela) e, en menor medida pola súa crise neste período, as históricas Xociviga do Carballiño. De xeito máis voluntarioso, pero igualmente efectivo para a difusión das creacións audiovisuais propias, engadiríanse as mostras de curtas que se propoñen en Bueu, Noia, Carballo e outras vilas galegas, así como as semanas de cine e programacións regulares que ofertan os doce colectivos repartidos polas provincias galegas, nalgún caso en poboacións carecentes de sala comercial, e integrados na Federación de Cine Clubs de Galicia ${ }^{12}$ (cadro 5). Finalmente, desde o ámbito universitario, sumándose tamén á difusión de filmes e autores propios, concretamente desde a Universidade de Vigo, cómpre salientar o asentamento do Curso de Medios Audiovisuais de Celanova (CEMAC), promovido coa Fundación Carlos Casares, e mais Augal. Audiovisual Galego, en Pontevedra co apoio da AGADIC.

Habería que mencionar, tamén, os voceiros especializados. Desaparecida en 2011, AG, Revista do Audiovisual Galego en soporte papel, saliéntase a consolidación de Scifiworld, ben asentada no mercado español, desde a súa fundación en 2005, editada en castelán desde Galicia, e centrada en xénero fantástico. 0 afianzamento da Rede e a mellora de custos que iso posibilita, fronte ao modelo tradicional de medios impresos, provocaron interesantes espazos de información e debate, como son a revista dixital A Cuarta Parede, o blog Acto de Primavera e o soportal do audiovisual galego AVG, ao abrigo do Consello da Cultura Galega, como as máis salientables e asentadas no bienio analizado ${ }^{13}$.

\section{UNHA FERVENZA DE CREADORES}

No referido ao talento, nos últimos anos semella confirmarse un interesante relevo, xeracional pero tamén creativo, que permite manterse expectantes ante o porvir do audiovisual propio. Tomando como base o formato longametraxe e como data referencial a de 1989, coa estrea das tres primeiras obras galegas e en galego: Sempre Xonxa (Chano Piñeiro), Urxa (Carlos A. L. Piñeiro, Alfredo Ga Pinal) e Continental (Xavier Villaverde), desde aquela considero que os cineastas galegos poden repartirse en catro grupos que, na miña opinión, serían os pioneiros, os de transición, os eclécticos ${ }^{14}$ e o cuarto grupo que xa reuniría os máis novos, "cunha bifurcación que incluiría aos que se dan en

${ }^{11}$ Con 9378221 espectadores, que deixaron a cantidade bruta de 55287 050,75 millóns de euros de recadación.

12 http://www.feciga.org/.

${ }^{13}$ Cfr. Jaime Pena (2014): «Signos de vida. 1989-2014», no catálogo da exposición Cinegalicia25, Santiago de Compostela, Xunta de Galicia, 88-101.

${ }^{14}$ Para maior detalle sobre o citado agrupamento autoral, consúltese Miguel Anxo Fernández (2014): «Galicia e o cine. Diversidade e identidade na procura de acomodo», Grial, 204, outubro, novembro, decembro, 13-27. 
etiquetar como Novo Cinema Galego (NCG), con propostas claramente abeiradas ata a expresión experimental»15. Entre os primeiros, con filme neste bienio, estarían Alfonso Zarauza, autor de Encallados (2013) e Os fenómenos (2014); Álex Sampayo (Schimbare, 2014); Alejandro Marzoa (Somos gente honrada, 2013); Isabel Ayguavives (El árbol magnético, 2013) e Carlos Sedes (El club de los incomprendidos, 2014), xunto a outros que durante este tempo non asomaron con obra longa ${ }^{16}$.

Parellos a eles, pero encadrados desde 2009 na marca Novo Cinema Galego, que non outorga patentes de adhesión nin acorda pautas programáticas, máis alá dunha certa mestizaxe de estilos, orixes e pretensións na modalidade de produción low cost, estrearían neste período autores como Lois Patiño (Costa da Morte, 2013), Ángel Santos (Las altas presiones, 2014) e Alberto García (O Quinto Evanxeo de Gaspar Hauser, 2013), xunto a Marcos Nine co documental de montaxe $A$ viaxe de Leslie (2014). O citado grupo achega outros nomes de variada praxe e ton, como Oliver Laxe, Eloy Enciso, Xurxo Chirro, Peque Varela, Marcos Nine, Eloy Domínguez Serén, Víctor Hugo Seoane, Olalla Castro e Fran Estévez, entre outros, que, aínda sen pertencer «de facto» ao NCG, si apostan por introducir un selo persoal de autor, moitos apoiados por produtoras cómplices, con Zeitun Films á cabeza xunto a outras na mesma liña ${ }^{17}$. Paradoxalmente, apréciase un interese pouco entusiasta en dotar esas imaxes da lingua propia, cuestión irrenunciable para dotar do seu carácter primixenio o cine galego, pero ese xa é outro debate que aquí non corresponde afrontar a pesar de ser preocupante polo que supón de rexeitamento á necesaria clave identitaria.

Como é natural, xunto a esta xenerosa nómina de creadores novos, permanece o restante espectro autoral, algúns xa con dilatada traxectoria e con filmes estreados entre 2013 e 2014, como son Xavier Bermúdez, con 0 ouro do tempo (2014); Juan Pinzás, con Sombras de Nueva York (2013); Jorge Algora, con Inevitable (2013); Margarita Ledo, con A cicatriz branca (2013), e Ignacio Vilar, con A esmorga (2014). E a participación en El niño (Daniel Monzón, 2014) de Vaca Films Studio, produtora que, xunto a Zircozine, son quizais as máis activas neste período cronolóxico no relativo a promover obra no formato grande. Da mesma maneira, habería que anotar o relativo baixón no protagonismo que Galicia viña mantendo na animación (o último Goya duplo foi en 2011 para Arrugas, coprodución da xa desaparecida Perro Verde), con dúas últimas achegas, La tropa de trapo en la selva del arco iris (2014), coproducida por Abano Films, e a chegada a porto, non sen tempo, da accidentada Holly Night ${ }^{18}$, do cambadés Juan Galiñanes, que a desaparecida produtora Dygra tiña previsto estrear en 2012 na modalidade 3D e que, finalmente, puido facer o propio Galiñanes en condicións titánicas.

En todo caso, a finais de 2014, cumpríase un cuarto de século de cine galego desde que en novembro de 1989, na mostra Cinegalicia desenvolvida en Vigo, se estrearan as tres primeiras longas galegas. Con tal motivo, artellouse na Cidade da Cultura, en Santiago de Compostela, a exposición Cinegalicia25, co ánimo de pór en valor o inxente valor do feito nese tempo por parte do sector audiovisual, acompañada dunha publicación que xurdía coa vocación de obra de referencia ${ }^{19}$ de cara a reafirmarse nun proceso que xa é irreversible: a dun audiovisual propio coa intención de ter presenza no mundo global como sinónimo dun país e da súa sociedade.

\footnotetext{
${ }^{15}$ Fernández, op. cit., 2014, 24.

${ }^{16}$ Casos de Jorge Coira, Luis Avilés, Sandra Sánchez e, mesmo, o ourensán Rodrigo Cortés, debutante coa rodaxe en Galicia de Concursante (2007) e lanzado ao mercado internacional co seu filme seguinte, Buried (2010).

17 Frida Films, Tic Tac, Portocabo...

18 Dygra Films pechou en xaneiro de 2012 e o negativo do filme foi embargado, acabou en propiedade de Abanca. Galiñanes conseguiu que a entidade bancaria accedese a cederlla para estreala de xeito restrinxido e «case heroico» o 7 de novembro de 2014.

19 VV. AA. (2014): Cinegalicia 25, Santiago de Compostela, Xunta de Galicia, 262. Con ensaios de Miguel Anxo Fernández, Xosé
} 


\section{UN FUTURO NA PROCURA DE ACOMODO}

Un dos efectos da crise económica arrastrada desde 2008 foi o de manifestarse na súa dureza, sobre todo entre 2012 e 2013, co peche irreversible de moitas produtoras, algunhas quizais asentadas sobre unha estrutura feble e en exceso acomodada ao subsidio público. Igualmente, houbo outras que tiveron que someterse a unha dolorosa reconversión. Como en calquera catarse, a convulsión deu paso a numerosas mudanzas en todas as ordes, pero o audiovisual propio mantense vivo, cunha achega a maiores de afloramento de talento, mentres na praxe empresarial tamén se produciron interesantes axustes de cara a afrontar un futuro distinto nunha comunidade cada vez máis globalizada. 0 noso audiovisual asume a racionalización de recursos e mais rigor nos proxectos que afrontar; tamén a necesidade de procurar coprodución externa e a aspiración de ser competitivos. A crise non desanimou os produtores e boa proba diso son os numerosos proxectos que anualmente saen beneficiados das axudas institucionais da Xunta de Galicia a través da AGADIC e mais da demanda de contidos de TVG, sen dúbida o principal motor do audiovisual galego, a pesar de rebaixar investimentos en produción allea. Para máis, a formación de profesionais novos está ben garantida desde o ámbito universitario e a formación especializada, malia as dificultades de reinserción laboral, certamente en niveis aínda alarmantes. Cómpre, iso si, idear e redefinir unha maneira de ver o mundo desde Galicia a través das imaxes, que permita asomar produtos singulares capaces de competir no mercado global, sen esquecer que o sector audiovisual galego está considerado estratéxico desde a promulgación da Lei do audiovisual en 1999. Como tamén asumir que a singularidade e a diferenza pasan por non renunciar á lingua propia. Son debates aínda pendentes.

Unha das consecuencias do bo ano que supuxo 2014 para o cine español foi romper co tópico de que o público propio non comungaba co seu cine. As cifras de asistencia e as cantidades recadadas confirman que tal cousa semella superada, sen deixar de recoñecer que niso tamén axudou a achega promocional de grandes grupos televisivos como Mediaset España Comunicación ${ }^{20}$ e Atresmedia Corporación, coprodutores de varios dos filmes. A unha escala máis modesta, recolleuse tamén en Galicia, onde $A$ esmorga foi capaz de levar miles de persoas ás salas cun produto presentado en galego con capital galego. Se hai pantallas, haberá público. Nese senso, as 170 pantallas computadas en 2014, coas que a exhibición galega tocaba fondo, xa están a ser amplamente superadas no ano 2015, tanto polas achegas da iniciativa privada como pola institucional; da mesma maneira que as previsións de estreas cinematográficas desde Galicia para o tempo inmediato permiten agardar presenza nesas pantallas con garantías de boa acollida. Ben é certo que aínda falta por superar o asunto da promoción e mais o da introdución do audiovisual nas aulas, sobre todo como nutriente cultural e como contribución á conciencia dun cine de seu nas futuras xeracións, necesario non só como canle de expresión, senón tamén para o mantemento da propia identidade como país. E niso convén andar.

Cadro 1. Subvencións de AGADIC para producións e coproducións en varios formatos

\begin{tabular}{cc}
2013 & 2014 \\
\hline 0 producións & 13 producións \\
\hline
\end{tabular}

Fonte: AGADIC.

Nogueira, Eduardo Galán, Jaime Pena e Xosé Enrique Acuña. 
Cadro 2. Resultados na recadación das coproducións galegas 2013-2014

\begin{tabular}{|c|c|c|c|c|c|c|c|}
\hline $\mathrm{N}^{\circ}$ & Título & Director & Coprodutora galega ${ }^{21}$ & Estrea & Espectadores & Recadación/€ & Outros \\
\hline 1 & EL NIÑO & Daniel Monzón & Vaca Films Studio & 28.8 .2014 & 2749173 & 16175804,74 & \\
\hline \multirow[t]{2}{*}{2} & EL CLUB DE LOS & Carlos Sedes & Bambú Producciones & 12.12 .2014 & 329142 & 2142351,31 & \\
\hline & INCOMPRENDIDOS & & & & & & \\
\hline \multirow[t]{2}{*}{3} & A ESMORGA & Ignacio Vilar & Vía Láctez Films, & 21.9 .2014 & 46842 & 272583,66 & \\
\hline & & & Editorial Galaxia & & & & \\
\hline \multirow[t]{2}{*}{4} & SOMOS GENTE & Alejandro Marzoa & Vaca Films Studio & 14.6 .2013 & 24841 & 150613,66 & \\
\hline & HONRADA & & & & & & \\
\hline \multirow[t]{2}{*}{5} & OS FENÓMENOS & Alfonso Zarauza & Zircozine, Tic Tac, & 11.12 .2014 & 15271 & 90351,13 & \\
\hline & & & Maruxina Film Company & & & & \\
\hline \multirow[t]{2}{*}{6} & EL ÁRBOL & Isabel Ayguavives & 235 Producciones & 25.11 .2013 & 1385 & 7016,95 & \\
\hline & MAGNÉTICO & & & & & & \\
\hline \multirow[t]{3}{*}{7} & LA TROPA DE & Álex Cols & Abano Producciones, & 30.4 .2014 & 5476 & 21919,19 & \\
\hline & TRAPO EN LA SELVA & & Continental Producciones & & & & \\
\hline & DEL ARCO IRIS & & & & & & \\
\hline 8 & COSTA DA MORTE & Lois Patiño & Zeitun Films & 26.9 .2014 & 3205 & 14769,40 & \\
\hline \multirow[t]{3}{*}{9} & INEVITABLE & Jorge Algora & Adivina Producciones & 10.4 .2014 & 2877 & 15688,04 & Tamén \\
\hline & & & & & & & estreada na \\
\hline & & & & & & & Arxentina \\
\hline \multirow[t]{3}{*}{10} & LAS ALTAS & Ángel Santos & Matriuska Producciones & 7.5.2015 & 1862 & 9120,80 & Presentada \\
\hline & PRESIONES & & & & & & en festivais \\
\hline & & & & & & & en 2014 \\
\hline 11 & LOS INCREÍBLES & David Valero & Frida Films & 28.11 .2013 & 811 & 2440,60 & \\
\hline 12 & O OURO DO TEMPO & Xavier Bermúdez & Xamalú Films & 1.8.2014 & 769 & 3711,90 & \\
\hline \multirow[t]{2}{*}{13} & A CICATRIZ BRANCA & Margarita Ledo & Nós Produtora & 30.8 .2013 & 378 & 2282,40 & \\
\hline & & & Cinematográfica Galega & & & & \\
\hline \multirow[t]{2}{*}{14} & SOMBRAS DE & Juan Pinzás & Atlántico Films & 14.6 .2013 & 135 & 949,60 & \\
\hline & NUEVA YORK & & & & & & \\
\hline 15 & O QUINTO EVANXEO & Alberto García & Zeitun Films & 30.13 .2014 & 46 & 140 & \\
\hline & DE GASPAR HAUSER & & & & & & \\
\hline
\end{tabular}

Fonte: Instituto de Cinematografía y de las Artes Audiovisuales, ICAA.

Cadro 3. Salas de exhibición en Galicia. 2013

\begin{tabular}{cccccc} 
& A Coruña & Lugo & Ourense & Pontevedra & Total \\
\hline $\mathbf{2 0 1 3}$ & 86 & 23 & 12 & 63 & 184 \\
\hline $\mathbf{2 0 1 4}$ & 80 & 16 & 12 & 62 & 170 \\
\hline
\end{tabular}

Fonte: Instituto de Cinematografía y de las Artes Audiovisuales, ICAA.

20 Participou como coprodutora en Ocho apellidos vascos e El Niño, os dous filmes españois máis vistos en 2014.

21 Boa parte delas inclúen a TVG como coprodutora ou participada, ademais de subvención da Xunta de Galicia a través da AGADIC. 
Cadro 4. Espectadores e recadacións nas salas de Galicia. 2013/2014

2013

\begin{tabular}{lrr}
\hline & Espectadores & Recadación \\
\hline A Coruña & 1588438 & 10177775,86 \\
\hline Lugo & 264295 & 168396,80 \\
\hline Ourense & 218131 & 1508531,95 \\
\hline Pontevedra & 949049 & 6476758,94 \\
\hline TOTAL & 3019913 & 19847027,55 \\
\hline \multicolumn{3}{c}{$\mathbf{2 0 1 4}$} \\
\hline A Coruña & 1850333 & 10732602,34 \\
\hline Lugo & 283934 & 1682516,70 \\
\hline Ourense & 269739 & 1642031,70 \\
\hline Pontevedra & 1208743 & 7217525,15 \\
\hline TOTAL & 3617749 & 21274675,89
\end{tabular}

Fonte: Instituto de Cinematografía y de las Artes Audiovisuales, ICAA.

Cadro 5. Cineclubs en Galicia. 2014

\begin{tabular}{cccc} 
A Coruña & Lugo & Ourense & Pontevedra \\
\hline 1 & 3 & 3 & 5 \\
\hline TOTAL: 12 & &
\end{tabular}





\section{INTERNET, SOCIEDADE E COMUNICACIÓN EN GALICIA}

Manuel Gago

Xosé López

Xosé Pereira

Universidade de Santiago de Compostela

Doi:10.17075/aceg.2016.006 



\section{INTRODUCIÓN}

O último bienio da vida de Internet supuxo un claro avance cara á interactividade e á participación constante da audiencia en todos os procesos de comunicación. O fenómeno da «autocomunicación», tal e como o concibe Manuel Castells, supuxo unha transformación clara sobre a cidadanía nos procesos de comunicación, especialmente no referido á emisión de mensaxes. Neste escenario, cómpre analizar polo miúdo tres variables que son as que se propoñen neste artigo. Primeiro, as posibilidades de conexión reais que ten a cidadanía galega para poder falar claramente de potencialidades reais da Sociedade da Información e do Coñecemento nun territorio concreto e definido como Galicia. Segundo, os usos que se fan desas posibilidades, prestando unha especial atención á mocidade, sen dúbida o principal motor de cambio de todo este proceso. Finalmente, debemos analizar a reacción que están tendo os medios de comunicación tradicionais ante o novo escenario.

Diciamos hai dous anos que o contexto, daquela, estaba marcado por unha fonda crise económica. Lamentablemente, esta situación continuou dun xeito máis ou menos constante durante os anos 2013 e 2014. Esta situación provocou serios problemas en grupos de comunicación moi consolidados, pero tamén abriu novas oportunidades a proxectos, moito máis modestos na súa concepción, que lograron abrirse un importante oco no consumo e na participación dos usuarios. Ademais, a tecnoloxía avanzou cara á conectividade global, a calquera hora e en calquera lugar, creando varios trebellos móbiles que permiten un uso moito máis compulsivo das ferramentas de conexión.

Estas novidades afondan na estratexia xa definida nos albores do século XXI, cando os protagonistas deixaron de ser os medios de referencia e as grandes figuras do xornalismo para centrarse no usuario e nas súas posibilidades. Por esas razóns, cómpre analizar polo miúdo como está afrontando a sociedade galega estes novos conceptos de conectividade global, de consumo activo e de consumo informativo a través de fluxos ininterrompidos de información.

\section{SITUACIÓN ACTUAL DA SOCIEDADE DA INFORMACIÓN}

A porcentaxe de conectividade a Internet da sociedade galega xa se aproxima ao sesenta por cento, cun incremento escaso pero constante ao longo dos anos que só se viu alterado por un salto de catro puntos entre o ano 2013 e 2014. Non obstante, Galicia segue sendo unha das comunidades autónomas con menor penetración de Internet, lonxe do 77 \% de penetración de Cataluña ou Madrid. Na actualidade, en Galicia un 58,3 \% da cidadanía conéctase con frecuencia a Internet en calquera das súas múltiples posibilidades, o que supón unha poboación de 1,6 millóns de persoas. Esta tendencia é a habitual desde a aparición de estatísticas sobre o uso de Internet en Galicia no ano 1997 e, de feito, é a tecnoloxía que máis avanza na súa penetración no fogar, xunto á televisión, que acada a cota do $87,1 \%$.

Porén, a comunidade galega quedou relegada á última posición neste indicador, incluso das comunidades que tradicionalmente ocuparon os últimos postos, que eran Estremadura e Cantabria.

1 Datos de Kantar Media de marzo de 2015 para Galicia. 
Gráfico 1. Porcentaxe de usuarios de Internet en España no ano 2015

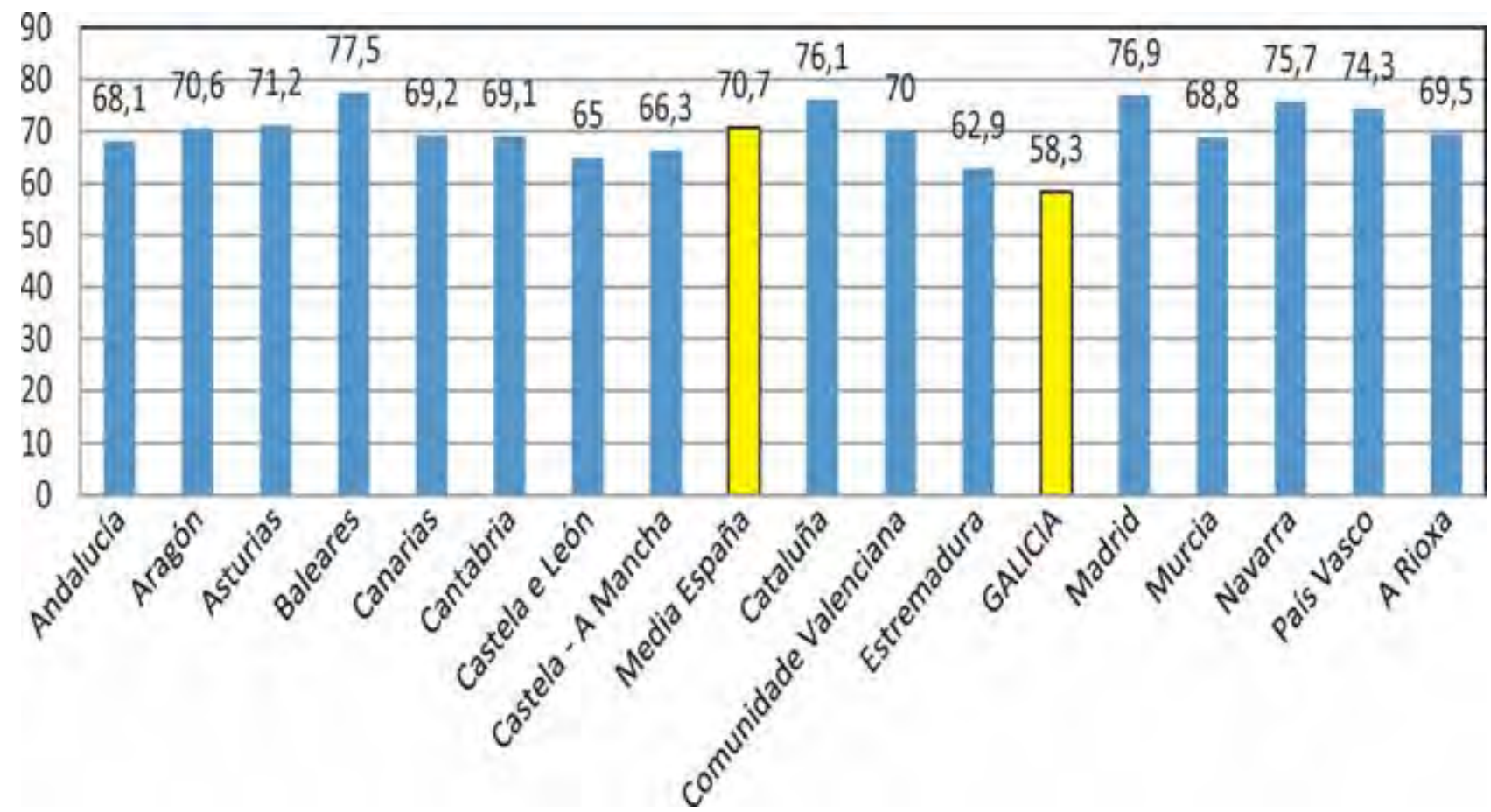

Fonte: Estudio General de Medios (EGM) 2015.

Esta situación aínda se agrava máis se se toma como referencia os indicadores da Unión Europea, onde a media xa se sitúa no 80 \% de penetración. Galicia non acada as cifras de países coma Bulgaria, que tiveron un desenvolvemento moito máis lento no seu histórico, e está moi lonxe doutros que se asemellan máis en canto á poboación, como pode ser Lituania, que acada xa a cota do $73 \%$.

Así e todo, no referido á calidade de conexión, obsérvase unha clara tendencia cara ao aumento do uso de sistemas de banda larga, fundamentalmente ADSL e cable.

O informe Diagnóstico 2013. A Sociedade da Información nos fogares galegos, elaborado pola Axencia para a Modernización Tecnolóxica de Galicia, deixa patente que a maioría dos fogares e das empresas galegas optan polas vías de alta capacidade para a súa conexión, chegando a cotas que superan o $65 \%$, con incrementos bianuais que superan o $23 \%$. A mellora dos nodos finais de conectividade, moito máis próximos aos fogares e creados con tecnoloxías dixitais, permite falar xa de niveis de cobertura de banda larga próximos á totalidade da poboación en Galicia. Aínda así, non se acadan as cotas medias da UE, pero a distancia supera lixeiramente os 10 puntos.

Este tipo de conexión de calidade ten unha especial incidencia nas contornas urbanas. Xustamente ao redor das cidades da Coruña, Vigo e Santiago é onde se producen os maiores índices de contratación de banda larga, superando as cotas do $70 \%$, máis semellantes ás medias europeas. 
Gráfico 2. Porcentaxe de usuarios de Internet por países da UE-27 no ano 2014

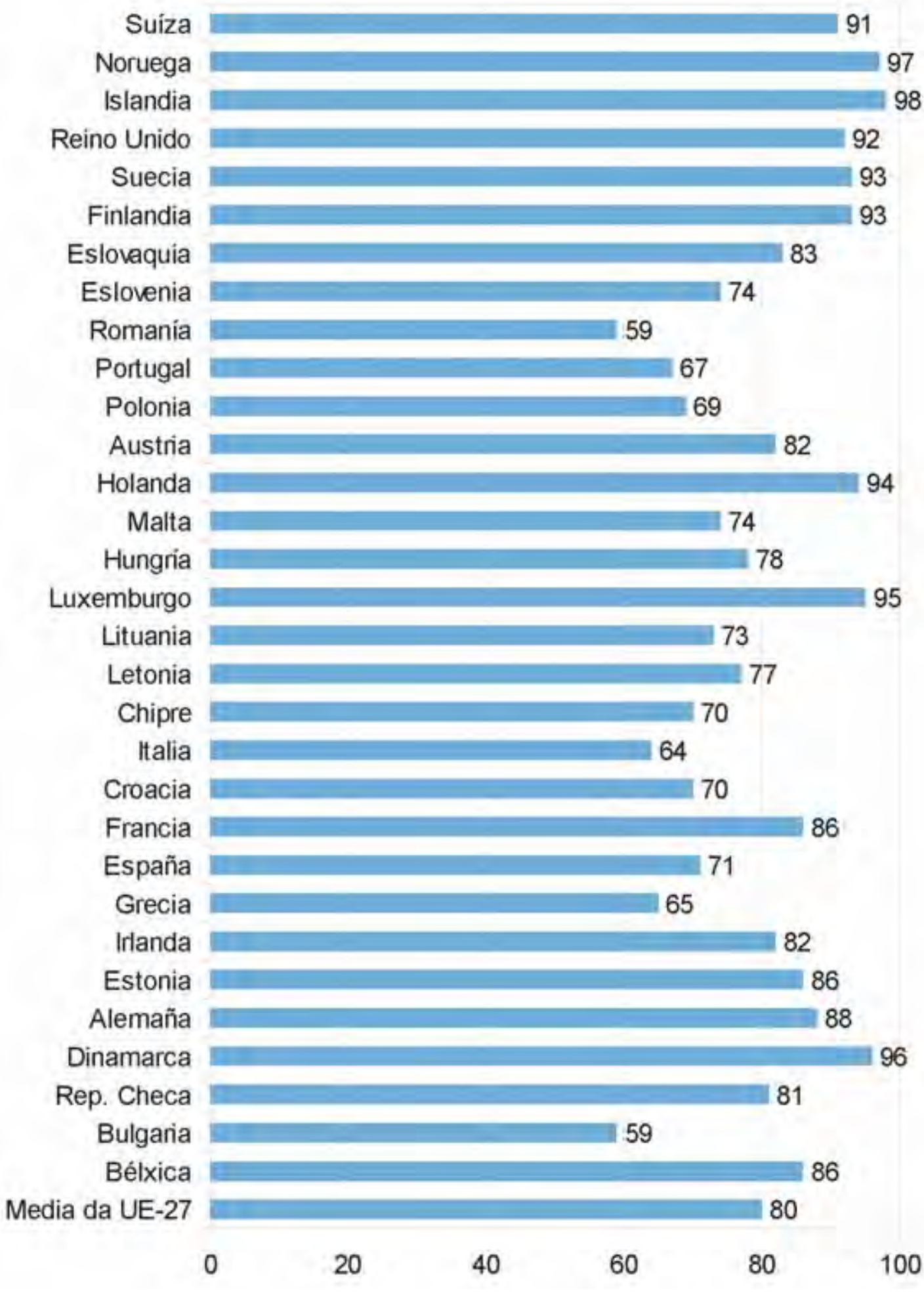
8 
Gráfico 3. Fogares conectados a banda larga e lugares onde hai máis conexión

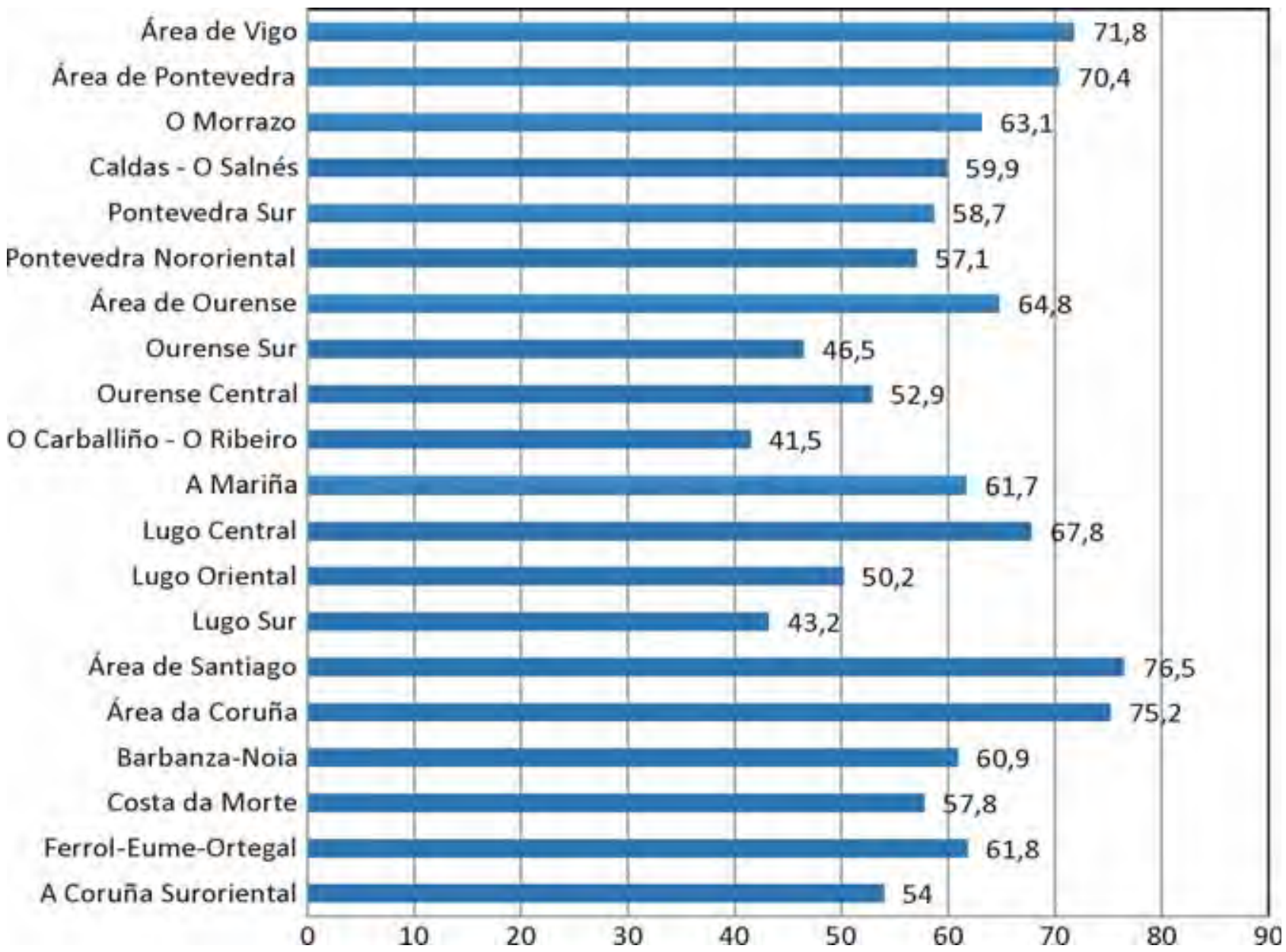

Fonte: Observatorio da Sociedade da Información e a Modernización de Galicia (OSIMGA) 2013.

Os principais condicionantes que provocan a non conectividade dentro da poboación galega fundaméntanse en tres eixes. 0 primeiro está vinculado á percepción de necesidade que pode ter o cidadán e a cidadá, o que provoca que máis da metade das persoas que non se conectan afirman que non lles resulta interesante. A segunda das caixas fundaméntase na falta de formación e de coñecementos para utilizar os dispositivos de conexión. Por último, a terceira causa principal de non conexión está directamente relacionada cos custos de conexión e de compra de equipamentos. Estas cifras están moi próximas ás medias españolas, con desviacións que raramente superan o $5 \%$.

A tendencia mundial actual en Occidente diríxese cara á creación de electrodomésticos que teñan a posibilidade de conectarse a Internet. Os que teñen unha maior penetración na actualidade son os televisores, aínda que nos últimos anos a 'internet das cousas' estase a estender a outros electrodomésticos.

O pulo desta tendencia necesariamente debe ir relacionado coa conectividade de alta capacidade e cun sistema tarifario por parte das operadoras máis dinámico que permitan, por exemplo, a combinación de varios servizos de conexión (móbil, fixa...) ou a incorporación de contidos exclusivos directamente vencellados co tipo de conexión prestado, como pode ser o caso de R ou de Movistar. 
Gráfico 4. Causas da non conexión

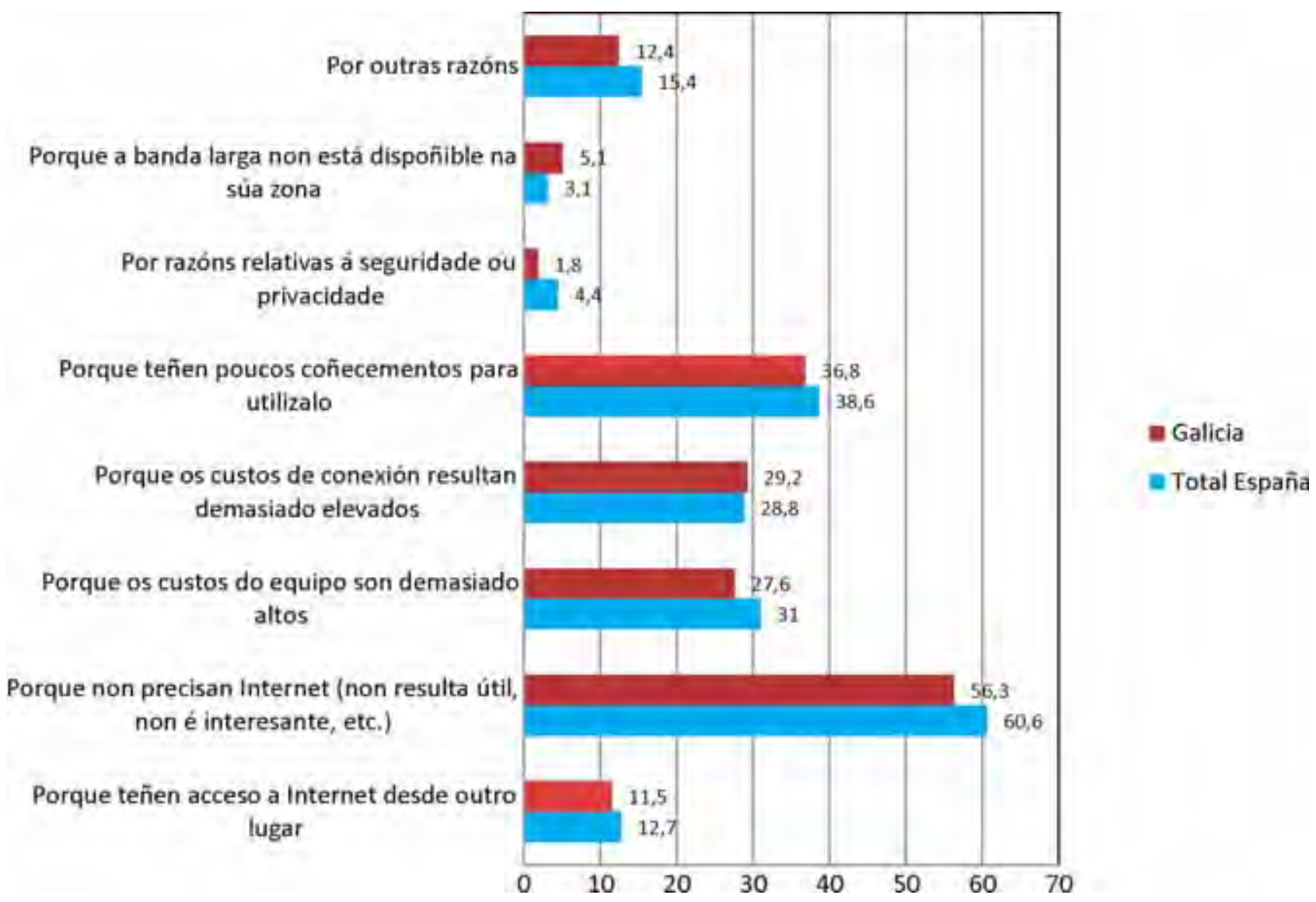

Fonte: INE 2014.

\section{SERVIZOS VINCULADOS Á SOCIEDADE DA INFORMACIÓN}

Analizada a conectividade, cómpre centrarse tamén nos servizos e no uso que fai a cidadanía das posibilidades que nos ofrece a conexión a Internet.

Igual que no informe anterior, decidiuse a análise pormenorizada da relación das e dos cidadáns coas administracións públicas, as encargadas de fomentar o uso das novas tecnoloxías. Igual que se indicaba no informe anterior, as porcentaxes de uso da poboación galega das posibilidades da administración electrónica son claramente superiores á media estatal, salientando as relacións a través de servizos web e de mecanismos de interacción activa. Destácase tamén o aumento constante do uso que fai a cidadanía das ferramentas para trasladar información e peticións á Administración, chegando a unha interesante cota que acada o $41 \%$.

Se ben a relación coa Administración é un indicador de interese, non é o uso principal da cidadanía. Os servizos máis usados non variaron ao longo dos anos, e a busca de información xunto ao envío e recepción de correo electrónico son accións habituais para practicamente o 90 \% da poboación. Merece tamén unha especial atención a variable «ler ou descargar noticias de xornais e revistas», con cotas tamén moi próximas á totalidade da información. As redes sociais continúan o seu ascenso iniciado hai dous anos, así como a banca electrónica, que aumentou o seu uso en máis de 12 puntos. Si parece estancarse o uso de Internet para vender produtos. 
Gráfico 5. Relación coa Administración

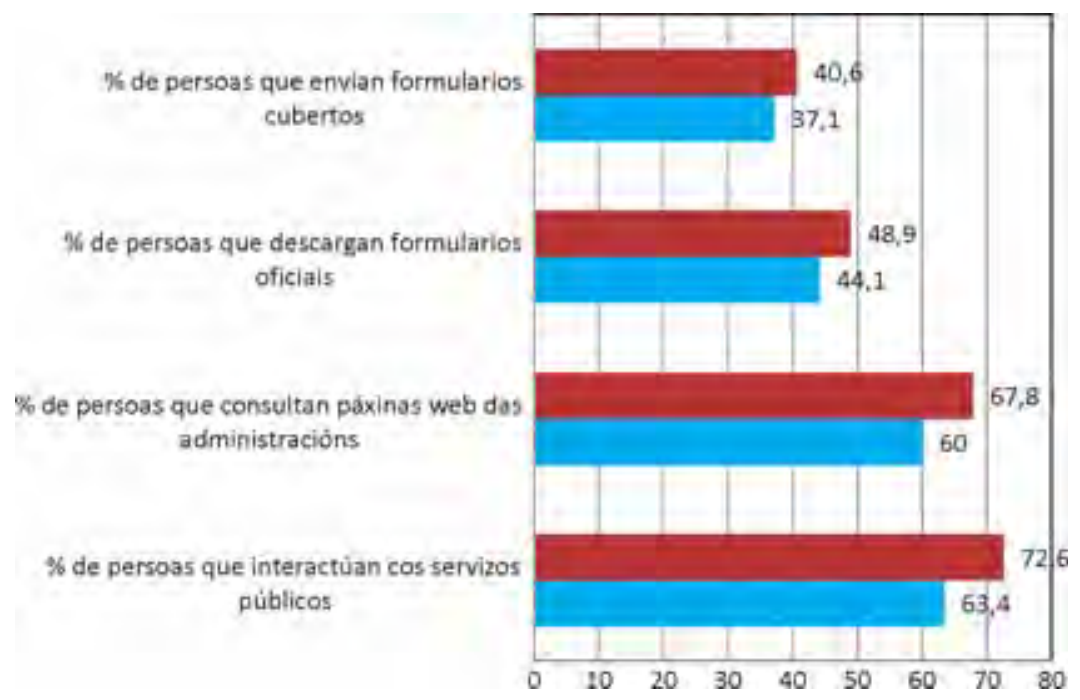

Fonte: INE 2014.

Gráfico 6. Tipoloxía do uso de Internet

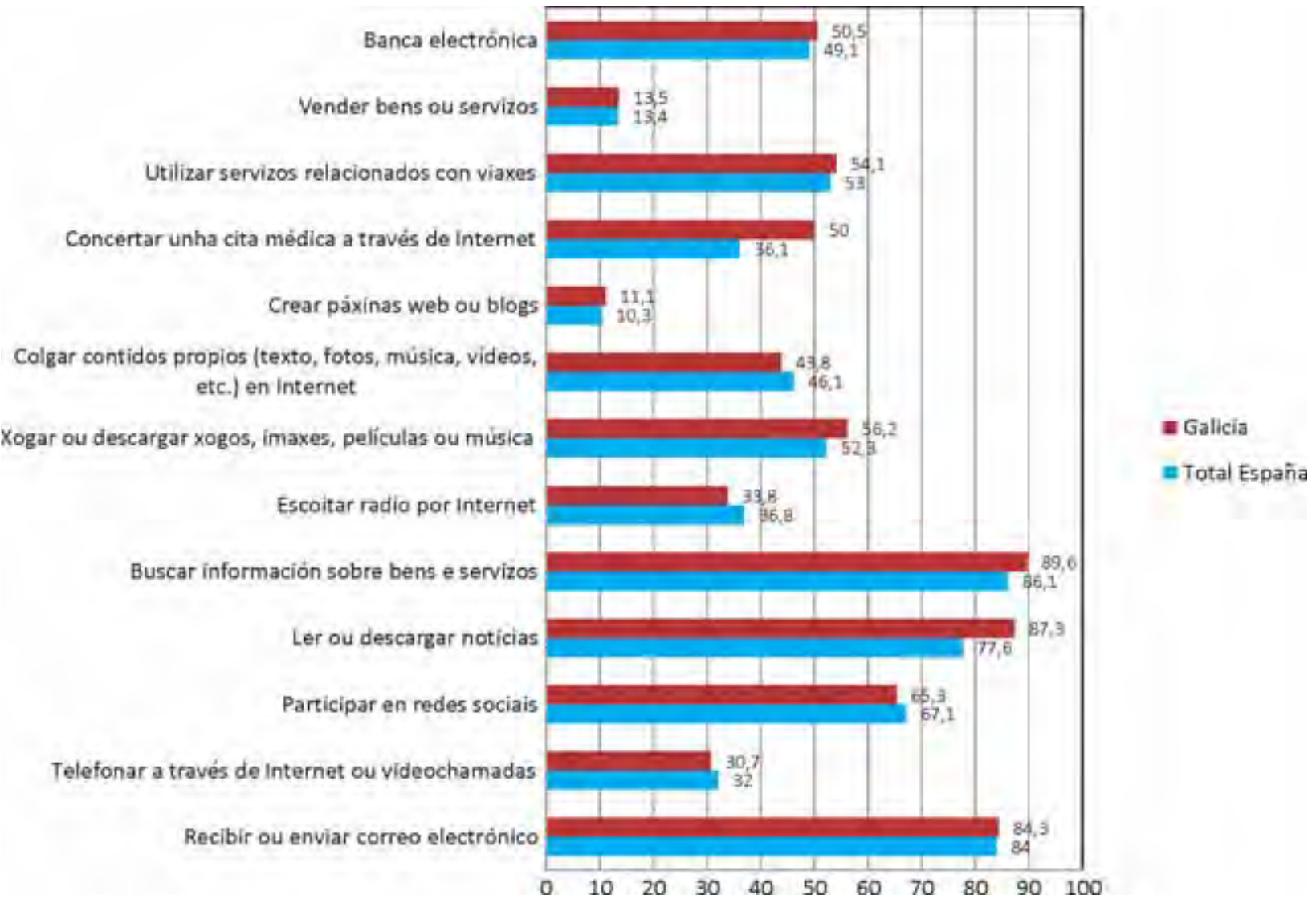

Fonte: INE 2014 
No caso dos nenos de 10 a 15 anos, as cotas de uso de tecnoloxía conectada a Internet aumenta sensiblemente con respecto ao resto da poboación, acadando case o 95 \%. É preciso tamén facer unha especial mención ao aumento progresivo de conexión dos nenos a través de tecnoloxías móbiles, ben sexan teléfonos ou ben tabletas electrónicas. De novo, os traballos escolares e as accións vinculadas ao ocio son as máis habituais neste segmento da poboación.

Gráfico 7. Uso das TIC polos nenos

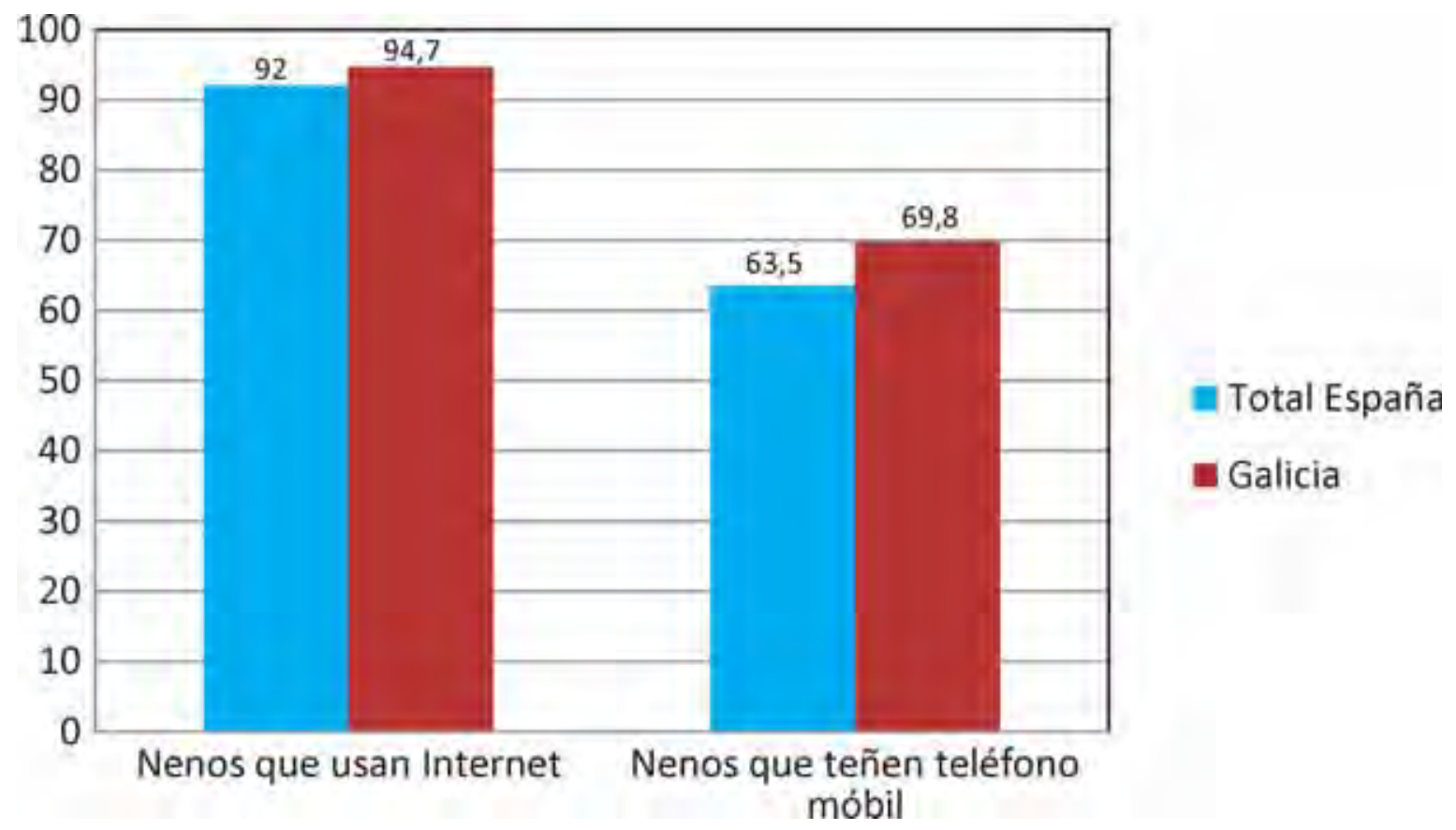

Fonte: INE 2014.

\section{ALFABETIZACIÓN DIXITAL}

Os procesos de alfabetización son unha das principais claves da evolución da conectividade dunha sociedade. Nestes procesos, cómpre facer unha distinción clara entre os denominados «nativos dixitais», cunha curva de aprendizaxe moi reducida, e as persoas que precisan investir máis tempo para aprender a usar calquera tipo de innovación que se produza neste terreo.

Nas sociedades occidentais, a tendencia é que os mozos e as mozas sexan xa nativos dixitais e que sexan os usuarios máis activos. En Galicia confírmase esa tendencia e os datos afirman que o 97,5 \% dos mozos e mozas con idades comprendidas entre os 16 e 24 anos acceden habitualmente a Internet. Estes índices son radicalmente distintos nos tramos de idade superiores aos 65 anos, onde o uso non acada a cota do $15 \%$.

Os nenos e as nenas son, ademais, un dos maiores motores da conectividade a Internet no fogar. A enquisa realizada pola Amtega sobre a Sociedade da Información nos fogares galegos indica o impacto da presenza de nenos no fogar, que provoca un aumento de 20 puntos nas cotas de conectividade. Xustamente a incorporación do uso das TIC e do acceso a Internet nos currícula de primaria permite consolidar a poboación máis nova como «nativa dixital». 
Gráfico 8. Uso de Internet segundo os tramos de idade

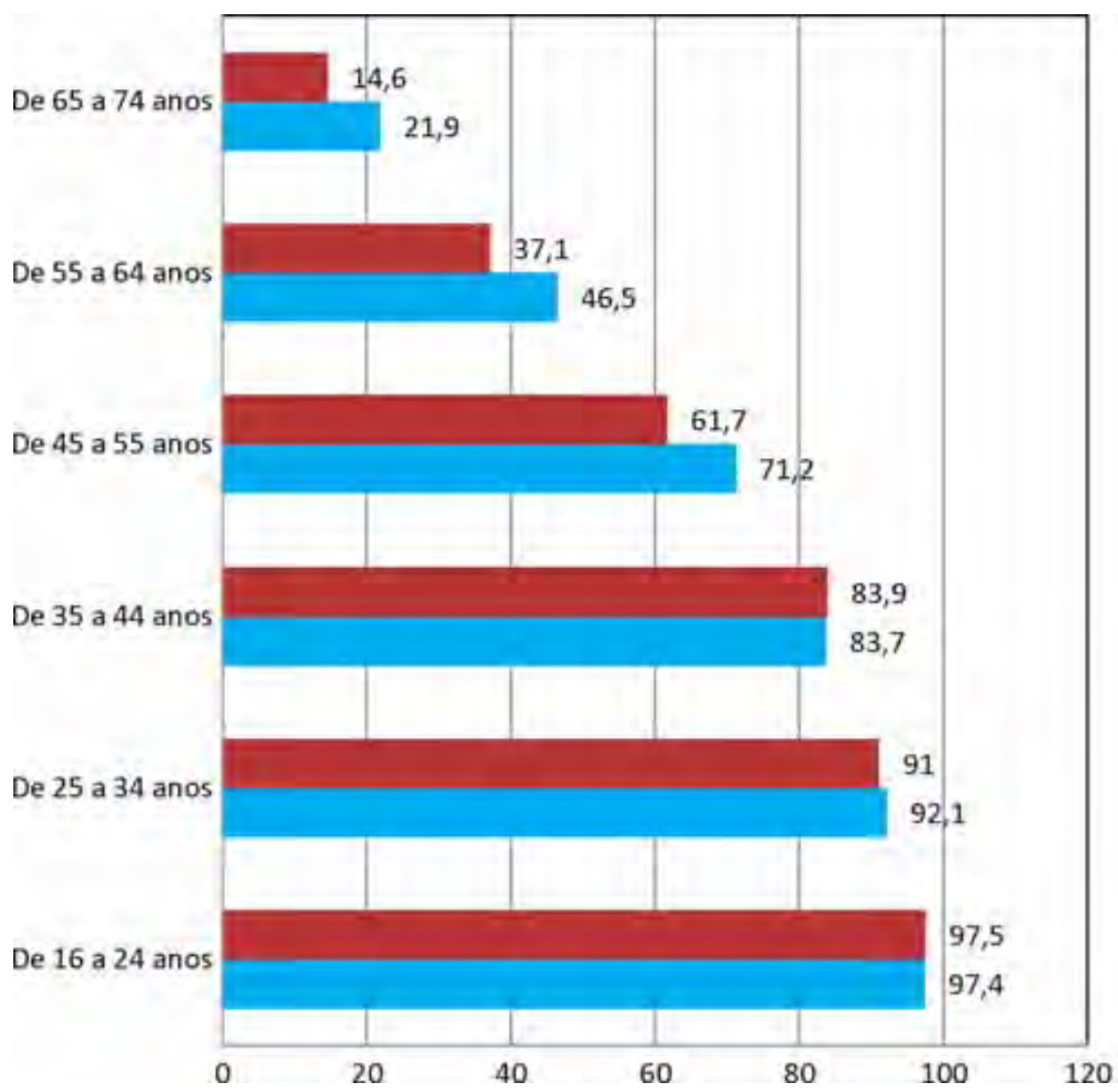

Total Galicia

Total España

Fonte: OSIMGA 2013.

Outros datos avalan tamén o grao de alfabetización dos últimos anos, por exemplo o aumento da percepción da utilidade das TIC e da conectividade a Internet. Podemos falar xa de certa unanimidade en considerar os servizos de conexión como elementos que melloran substancialmente a calidade de vida, especialmente en aspectos tan sensibles como a educación, a vida laboral ou as relacións sociais. Estes datos supoñen un importante avance na concepción da conectividade como elemento importante para poder desenvolver as tarefas diarias dun xeito máis satisfactorio.

Outro indicador de interese para comprender a consolidación da tendencia positiva de alfabetización dixital está relacionada coa autopercepción de dominio das ferramentas. En Galicia, de xeito semellante ao resto de España, practicamente a metade dos usuarios de Internet considérase avanzado ou experto, especialmente nas ferramentas máis consolidadas como pode ser a navegación por Internet, o correo electrónico ou o uso das aplicacións ofimáticas (procesadores de texto, follas de cálculo...).

Con todo, nas ferramentas máis novas, como as xestoras de redes sociais, o grao de percepción varía sensiblemente e tan só o $20 \%$ dos seus usuarios se consideran usuarios avanzados ou expertos. É importante destacar que estes datos tenden cara a unha homologación ao longo do tempo, determinando claramente que os procesos de alfabetización, especialmente nas persoas non nativas, require un período de tempo medio para poder consolidarse. 
Gráfico 9. Percepción de que as novas tecnoloxías melloran a calidade de vida. As novas tecnoloxías son boas ou moi boas para...

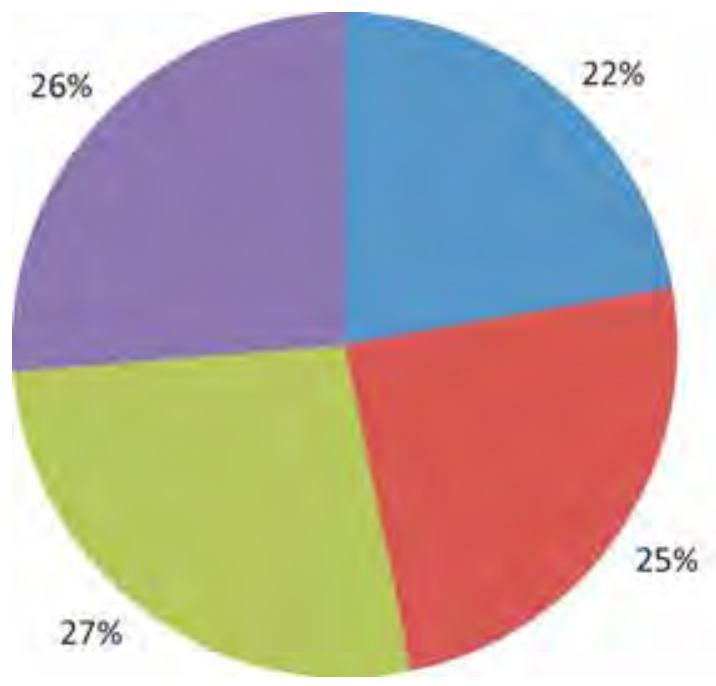

- Para relacionarse socialmente

- Para facer a vida máis sinxela

= Para a educación

Para o mundo laboral

Fonte: Observatorio Nacional de las Telecomunicaciones y de la Sociedad de la Información (ONTSI) 2014.

Gráfico 10. Percepción do coñecemento do uso das tecnoloxías

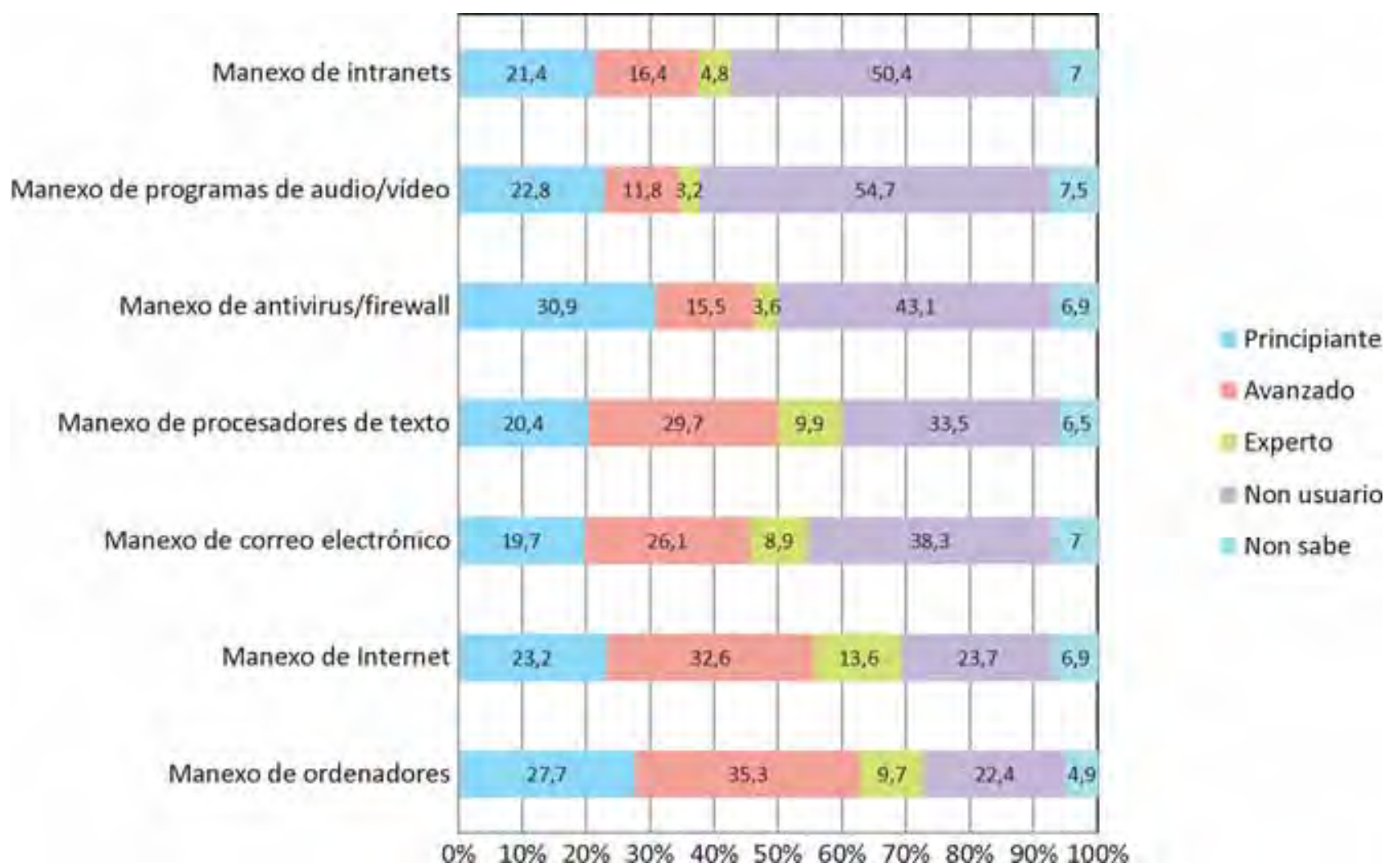

Fonte: ONTSI 2014. 
Sen dúbida, as consecuencias do coñecemento das ferramentas e da súa percepción de utilidade son as que definen o aumento da conectividade en todos os contextos, destacando sobre todo a conexión desde o fogar e desde o traballo. Lonxe quedan as primeiras estatísticas de finais dos anos 90, que deixaban patente a baixa conexión dos fogares en beneficio dos lugares de traballo e de estudos. Hoxe, queda patente que maioría dos galegos e das galegas se conectan desde lugares definidos e tan só un 7 \% da poboación segue acudindo a locutorios para poder facer as súas conexións. Pero, quizais, a principal novidade é o aumento exponencial da conexión a través de dispositivos móbiles, acadando unha cota que supera o $84 \%$ das persoas que se conectan a Internet, especialmente a través do teléfono móbil, cunha cifra que acada o $70 \%$ do total.

Gráfico 11. Lugar de conexión habitual

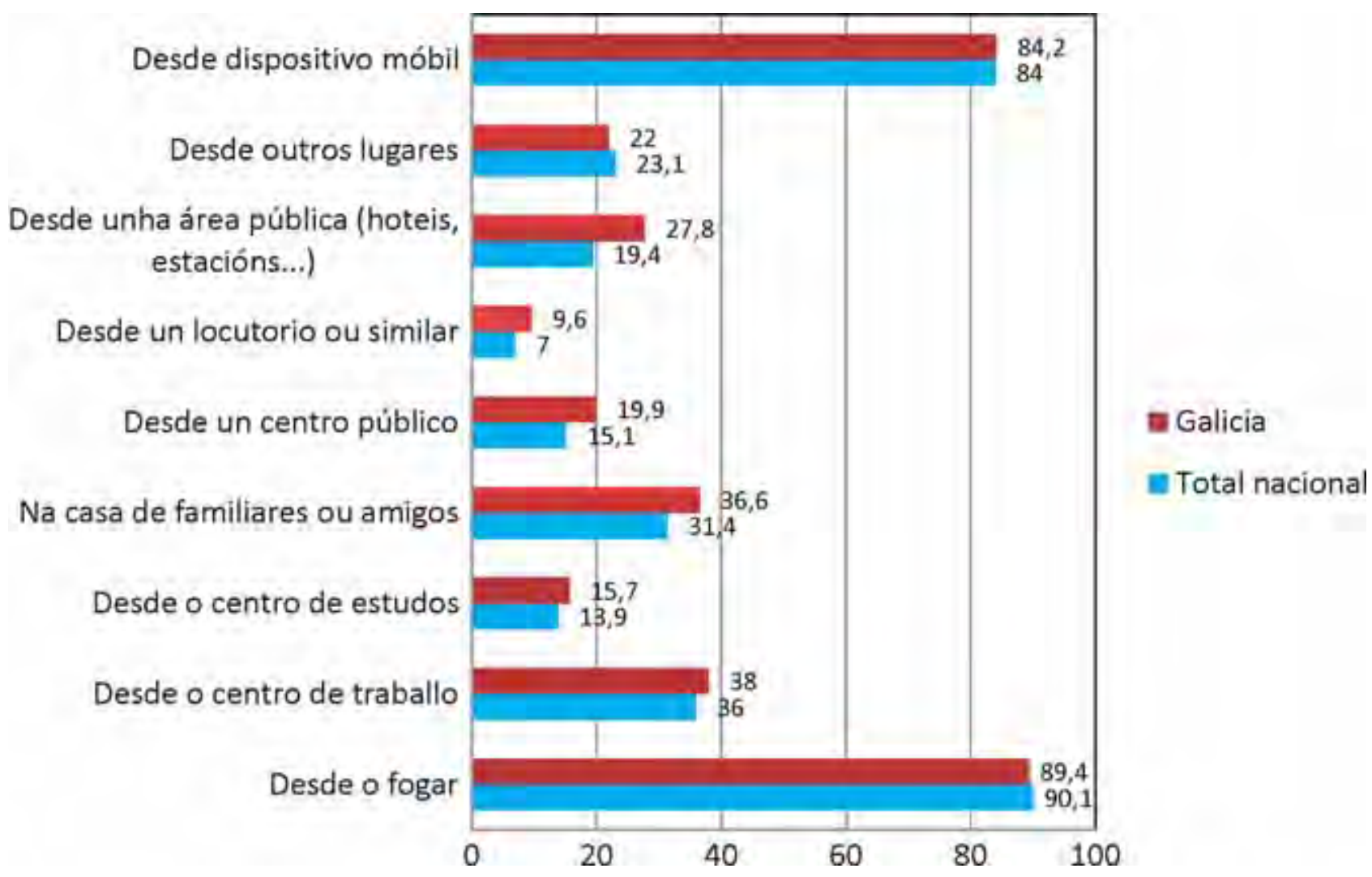

Fonte: INE 2014.

\section{CIBERMEDIOS: INCERTEZAS Á VOLTA DE 2015}

O panorama dos medios dixitais con orixe no papel apenas cambiou no interludio entre uns e outros informes da comunicación. Caracterízase polo estatismo na evolución dos cibermedios, a ausencia de innovación en contidos -agás determinados exemplos híbridos que veremos- e tímidos proxectos de muro de pagamento que non chegan a facerse efectivos.

Esta conxelación da innovación en cibermedios ten o seu correlato nunha segunda fronte: a destrución dun contorno público que poida avaliar os resultados dos cibermedios na rede, os marcos de competencia e a presenza dun dos fenómenos máis interesantes dos últimos anos: os micromedios. 
A escasa audiencia dos cibermedios galegos esvaece, ademais, os seus resultados no conxunto español. As dúas frontes tradicionais para aproximarse á audiencia galega eran o Estudio General de Medios (EGM) e as actas da Oficina de Justificación de la Difusión (OJD). No caso do EGM, a última vaga (febreiro-marzo 2015), o primeiro cibermedio galego en figurar no moi competitivo ránking de sitios web é lavozdegalicia.es, no posto vinte dun total de vinte e cinco sitios web, con 520000 visitas ao seu sitio nos últimos trinta días. O repartimento de visitantes do ránking permite, ademais, observar a evolución de Internet como un espazo de entretemento audiovisual no que os medios ocupan, cada vez máis, un punto máis especializado. Deste xeito, Youtube é o sitio web hexemónico a unha enorme distancia dos seguintes, seguido de Elpais.com, Marca, Twitter, As.com, Antena3.com, Rtve.es e Lasexta.com.

No caso de OJD Interactiva, que ofrece unha información bastante exhaustiva do comportamento da audiencia dos cibermedios a través das súas actas, nos últimos anos boa parte dos cibermedios galegos deixaron de ser auditados por ela. Só sobreviven dous: Galiciae (que aglutina Diario de Pontevedra e El Progreso) e elcorreogallego.es, dos que analizaremos as actas de xuño de 2015.

En canto a Galiciae, este produto do grupo El Progreso ten unha media diaria de máis de 35000 visitas nun contexto favorable: segundo OJD, o número de visitas por navegadores únicos pasou os últimos doce meses de preto de 250000 a máis de 400 000, o cal indica unha progresión máis que notable que non pode ser analizada en detalle debido á precariedade de datos.

Verbo de elcorreogallego.es, as estatísticas de OJD sitúan o número de visitantes medio deste produto en case 30000 visitantes, que se mantiveron estables e sen crecementos significativos durante os últimos doce meses, xerando unha media de algo máis de 400000 navegadores únicos/mes durante todo o período.

Un elemento significativo é a gran diferenza na audiencia da páxina de inicio entre elcorreogallego.es e galiciae.com. Se en elcorreogallego.es a portada supón case un 30 \% do tráfico, no caso de Galiciae a portada oficial supón menos dun $1 \%$ do tráfico total. Isto desvela que boa parte do consumo deste medio provén dos seus subdominios locais, elprogreso.galiciae.com e diariodepontevedra.galiciae.com, e sinala a dificultade por conseguir crear unha edición electrónica de ámbito galego por parte do grupo propietario.

\section{UNHA ANÁLISE DOS CIBERMEDIOS GALEGOS A TRAVÉS DE GOOGLE TRENDS}

Cremos necesario, malia as enormes dificultades técnicas e a imprecisión de moitos dos sistemas de análise baseados en datos aproximativos, prestar atención ao funcionamento global do sector de comunicación en Galicia. Para iso, empregamos a ferramenta Google Trends. A principal fonte de datos de Google Trends son as buscas dos usuarios. $\mathrm{Na}$ medida en que o comportamento de moitos usuarios na actualidade é prescindir da barra do navegador para introducir as URL e acceder, pola contra, a través de buscas en Google, Trends pode achegarnos datos interesantes que sempre van ofrecer unha maior precisión canto máis masivos sexan.

No noso estudo de cibermedios galegos realizamos unha análise dos últimos doce meses dos patróns de consumo dos cibermedios galegos, nos que podemos destacar os seguintes aspectos:

Tres escalas de audiencia. A primeira escala ocúpaa en solitario La Voz de Galicia. Malia sufrir un descenso de aproximadamente un $20 \%$ no primeiro semestre de 2015, parece remontar cara a finais deste período. $\mathrm{Na}$ segunda escala está o Faro de Vigo, ocupando unha posición intermedia entre La Voz de Galicia e a terceira escala. Na terceira escala están os xornais de ámbito máis local, cunha posición moi baixa e no límite da visibilidade. É neste espazo onde o sistema comeza a transformarse e se observa a competencia entre estes medios de carácter moi local e iniciativas xornalísticas de nacenza dixital con maior ou menor veteranía.

Permanencia do ámbito de influencia local. A análise de Google Trends revela como os medios galegos teñen tráfico de audiencia basicamente residual procedente do exterior. O seu consumo é esencialmente de ámbito 
autonómico e moi vinculado ás súas áreas de influencia orixinais do papel, pero que tamén están presentes no seu contido editorial.

Consumos complementarios. Google Trends permite comprobar que os medios son consumidos na rede de forma complementaria. Nas buscas relacionadas con cada un dos termos podemos observar como os usuarios tamén consomen medios da competencia, medios especializados (deportivos) e medios de ámbito español (sobre todo EI País e, en menor medida, El Mundo). Na medida en que o medio ten unha implantación e un número de buscas maior, aparece tamén a combinación coas redes sociais, pouco apreciable nas buscas relacionadas dos usuarios que consomen medios pequenos.

\section{MUROS DE PAGAMENTO E OUTROS SISTEMAS DE FINANCIAMENTO}

No contorno dixital, os cibermedios galegos seguen a basear os seus ingresos esencialmente nas canles publicitarias, se ben nos últimos anos houbo diferentes movementos que apuntan dun xeito tímido cara a un cambio do modelo de negocio que aínda está por ver se se implementará definitivamente. Podemos distinguir catro estratexias diferentes en relación con modalidades distintas de obtención de ingresos.

a) Previsualización e rexistro gratuíto: é o modelo seguido por La Voz de Galicia. A partir da detección da frecuencia de uso do medio por parte do usuario, La Voz de Galicia obriga a un rexistro para continuar.

b) Previsualización e subscrición: é o caso do Faro de Vigo. A partir dun determinado número de consultas ao medio, este péchase e ofrece unha subscrición a un prezo moi competitivo (30€ ano).

c) Avance de contido: o medio ofrece o corpo de titulación, entradiña e, ás veces, o seguinte parágrafo, remitindo ao lector á edición en papel (ou a algunha plataforma como pode ser Orbyt, no caso de El Correo Gallego). É o caso de El Correo Gallego, El Progreso ou Sermos Galiza.

d) Doazón voluntaria: máis propio de medios nacidos electrónicos, este recurso é practicado por Galicia Confidencial ou Praza Pública. Ás veces, este sistema de doazóns compleméntase con servizos premium para os usuarios que ingresan diñeiro para o medio.

O resto dos medios empregan fórmulas de carácter publicitario para a obtención de resultados económicos, permitindo un libre acceso ao contido.

\section{OS MICROMEDIOS: UN SOPORTE DE DIFÍCIL MONETIZACIÓN}

A crise económica, os cambios no sector da comunicación e a dinámica de transformación das redes sociais provocaron estes anos o nacemento do que se definiu como micromedios: as cabeceiras mantidas por usuarios ou pequenos grupos de particulares que inclúen as diferentes dinámicas propias dun medio de comunicación pero a pequena escala: elaboración de contidos xornalísticos, facturación publicitaria ou por outras vías.

Por unha banda, xornalistas que procedían de medios de comunicación tradicionais construíron pequenos medios de comunicación na procura de espazos de nicho temáticos ou locais. Canda medios xa veteranos como Galicia Confidencial ou Disque Cool, únense outros como Pontevedra Viva, Mundiario, Stadio Sport, Dxtbase.com, Trueiro, Benbo, Magazine Cultural M, La Alacena Roja, etc. Non é o propósito do informe recoller a grande explosión de publicacións que, como as previamente citadas, explotan medios de nicho ou locais moi distintos, desde información deportiva ata gastronómica. Un aspecto salientable é a creación, desde Ourense, de Opennemas, unha interesante 
iniciativa que ofrece software de publicación xornalística gratuíto a base de compartir resultados publicitarios, e con diferentes modalidades de prezos para ampliar posibilidades técnicas. Opennemas está promovido pola empresa Openhost.

Por outra banda, os blogs -que foran tan relevantes para a cultura e a lingua galegas a mediados da década pasada- foron migrando cara a redes sociais propietarias e privadas como Facebook ou Twitter; os blogs superviventes profundaron no camiño da especialización temática. O panorama é notablemente distinto, polo tanto, ao da década anterior: os blogs foron asumidos como ferramentas de comunicación corporativa -tanto por parte das empresas da cultura como por todo tipo de entidades pequenas públicas e privadas- e tamén como formas de expresión da marca persoal, canda as redes sociais de capital privado. 


\section{REFERENCIAS BIBLIOGRÁFICAS}

CASTELLS, M. (2009): Comunicación y poder, Madrid, Alianza Editorial.

FogeL, J. F. (2007): La prensa sin Gutenberg: el periodismo en la era digital, Madrid, Punto de Lectura.

EGM (2015): Resumen general de resultados. Octubre 2014-mayo 2015 (http://www.aimc.es) [última consulta: 24/04/2015]. OSIMGA (2014): A Sociedade da Información nos fogares galegos. Ano 2013, Santiago de Compostela, Xunta de Galicia.

ONTSI (2014): Las TIC en los hogares españoles. Estudio de demanda y uso de Servicios de Telecomunicaciones y Sociedad de la Información, Madrid, Gobierno de España.

\section{BASES DE DATOS UTILIZADAS}

Eurostat

INEBase

IGE 


\section{AS INFRAESTRUTURAS DE TELECOMUNICACIÓNS}

\section{Domingo Docampo}

Universidade de Vigo

Doi:10.17075/aceg.2016.007 



\section{INTRODUCIÓN}

Nos anos obxecto da presente análise, en particular o 2013, asistimos a unha morea de cambios normativos nos sectores das comunicacións e do audiovisual. Tamén a unha concentración de operadores de telecomunicacións e do audiovisual anunciada xa desde hai algúns anos: a absorción do operador de cabo ONO por Vodafone, a compra de Canle Satélite Dixital por Telefónica e a case finalizada operación de compra de Jazztel por parte de Orange. En particular do porqué da aceleración do proceso de compra de ONO e Jazztel pretendemos achegar algunha clave no presente informe.

Malia a crise, foron anos de crecemento na demanda de servizos, de especial relevo no caso de banda larga móbil, con máis de dez millóns de novos contratos, mentres se está a producir o despregamento das novas redes 4G/LTE, o novo estándar de comunicación capaz de fornecer moi altas velocidades de transmisión.

Desde o punto de vista normativo, cómpre salientar, en primeiro lugar, a entrada en funcionamento, o 7 de outubro de 2013, do novo organismo regulador, a Comisión Nacional dos Mercados e a Competencia (CNMC), que integrou as actividades e función que viña desenvolvendo a Comisión do Mercado das Telecomunicacións. Producíronse, ademais, cambios importantes na regulación do sector TIC a nivel estatal, plasmados nunha nova Lei xeral de telecomunicacións, aprobada o 15 de maio de 2014, e a nivel europeo, cunha batería de medidas orientadas a garantir a igualdade de condicións dos operadores no despregamento das novas redes.

As tendencias presentes nos anos de crise mantivéronse nestes últimos dous anos, con baixadas de facturación no sector debidas, en parte, ás reducións de prezos e a unha maior competencia na prestación dos servizos básicos. Emporiso, o sector TIC seguiu incrementando cifras de penetración na banda larga móbil: o número de liñas con acceso a Internet desde unha rede móbil superou os 35 millóns a finais de 2014, chegouse daquela a un elevado número de subscricións de Internet móbil por cada 100 habitantes, máis de 78 a principios de 2015, o que coloca a España nunha posición de vangarda na Internet móbil en Europa.

Pola súa banda, o parque de conexións de banda ancha fixa creceu por riba do $6 \%$ ata un total de máis de 12 millóns de liñas, das que o $15 \%$ son accesos de alta velocidade $\mathrm{NGA}^{1}$, o que supón un crecemento do $50 \%$ de liñas de alta velocidade con respecto a 2012, segundo recolle o último informe anual da Comisión do Mercado das Telecomunicacións (CMT 2014), no que se achegan os indicadores a finais do ano 2013.

Na década en que andamos, somos testemuña de profundos cambios no uso e acceso ás infraestruturas de telecomunicación, coa banda larga abríndose paso a través das tecnoloxías sen fíos e da fibra óptica. Parece oportuno na presente achega poñer o foco nas infraestruturas de telecomunicación, facendo unha descrición detallada destas nas comunidades autónomas (CC. AA.), o que vai permitir analizar con precisión a posición de Galicia no conxunto do Estado. Para esa análise imos utilizar exclusivamente datos consolidados nos informes oficiais da CMT, agora serán da CNMC, do que o último anual de que dispoñemos (2014) achega información sobre indicadores de infraestruturas ata decembro de 2013 detalladas por CC. AA. Ano e medio despois, o momento en que se dá remate ao presente informe, houbo avances significativos na posta en marcha de tecnoloxías e infraestruturas, como

\footnotetext{
${ }^{1}$ Next-generation access (NGA) designa unha mellora substantiva do largo de banda dispoñible grazas aos avances en velocidade e calidade do servizo.
} 
xa quedou reflectido nos comentarios sobre a penetración da Internet móbil, mais os indicadores a finais de 2014 fornecen unha imaxe realista da situación de Galicia no contexto español.

Ao longo do traballo imos facer uso dos seguintes acrónimos nas gráficas comparativas:

$\begin{array}{llll}\text { España } & \text { ESP } & \text { Comunidade Foral de Navarra } & \text { NAV } \\ \text { Andalucía } & \text { AND } & \text { Comunitat Valenciana } & \text { VAL } \\ \text { Aragón } & \text { ARA } & \text { Estremadura } & \text { EXT } \\ \text { Canarias } & \text { ILC } & \text { Galicia } & \text { GAL } \\ \text { Cantabria } & \text { CAN } & \text { Illes Balears } & \text { BAL } \\ \text { Castela-A Mancha } & \text { CLM } & \text { A Rioxa } & \text { LAR } \\ \text { Castela e León } & \text { CYL } & \text { Euskadi } & \text { EUS } \\ \text { Catalunya } & \text { CAT } & \text { Principado de Asturias } & \text { AST } \\ \text { Comunidade de Madrid } & \text { MAD } & \text { Rexión de Murcia } & \text { MUR }\end{array}$

\section{INFRAESTRUTURAS CON SOPORTE FÍSICO}

\section{Telefonía fixa}

As infraestruturas para telefonía fixa son as mesmas que se utilizan para a prestación dos servizos de banda ancha sobre soporte físico. A penetración da telefonía fixa iniciou unha senda descendente a partir de finais da pasada década, a medida que se ía completando o despregamento da telefonía móbil.

Figura 1. Penetración da telefonía fixa no período 2005-2013 en España

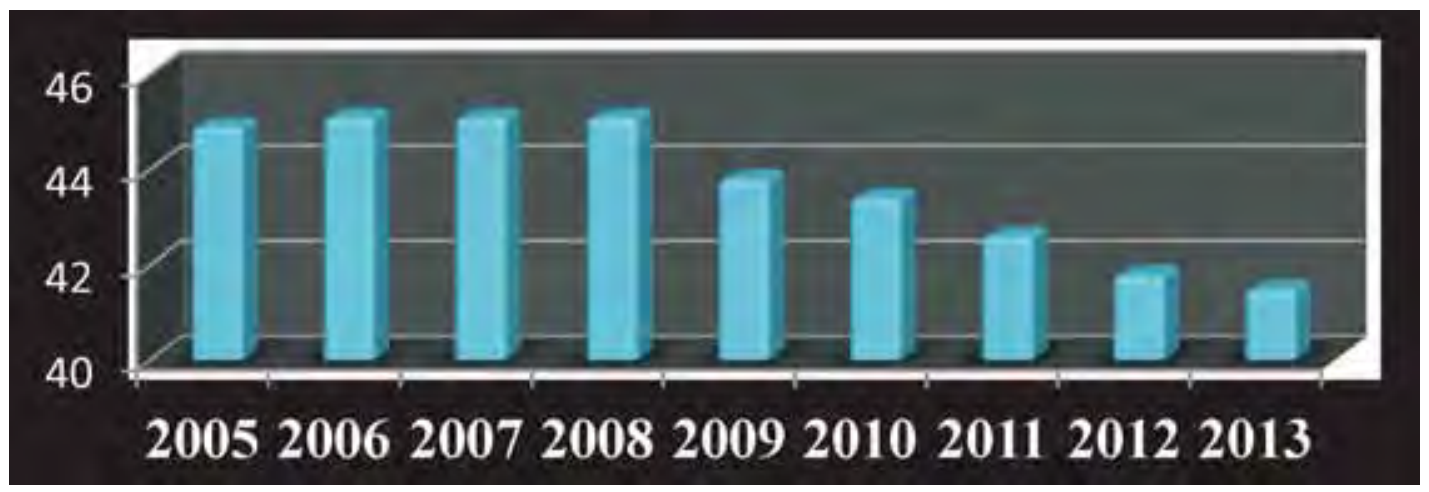

Fonte: CNMC, informe anual sobre as telecomunicacións 2014.

Pasamos nese intervalo temporal dunha penetración do $45 \%$ en 2005 a un pouco máis de $41 \%$ en 2013, como se reflicte na figura 1 .

Máis relevante é o dato de quen presta os servizos de telefonía fixa por CC. AA., xa que é un indicador que apunta ao grao de competencia real na prestación dese servizo. A figura 2 proporciona unha información moi valiosa sobre o grao real de liberalización dos servizos de telefonía fixa, de máis a menos de esquerda a dereita: as CC. AA. onde a cota de Telefónica no mercado de telefonía fixa é menor son aquelas en que ou ben hai un operador alternativo de cabo ou a competencia pola xestión dos servizos de telefonía fixa entre os operadores de telefonía é maior. 
Figura 2. Porcentaxe das liñas de telefonía fixa nas CC. AA. en 2013 a cargo de:

Telefónica (azul), operadores de cabo (vermello) e resto de operadores (verde)

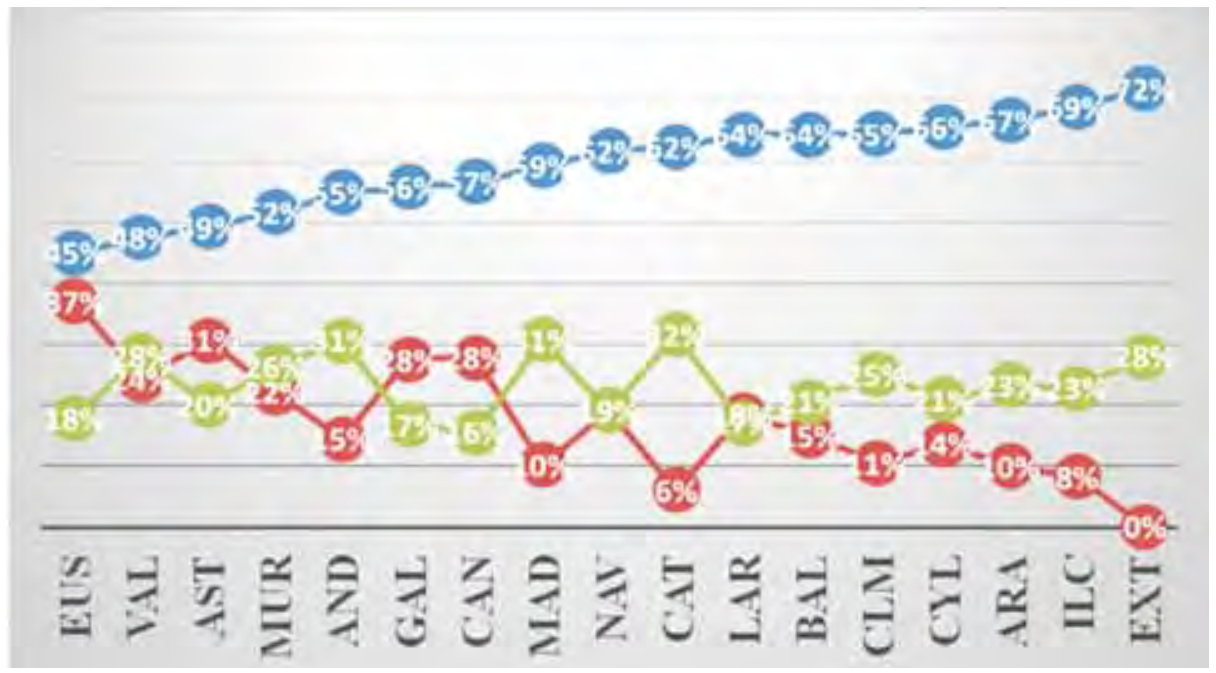

Fonte: CNMC, informe anual sobre as telecomunicacións 2014.

Como vemos, Galicia, grazas á presenza do operador de cabo R, presenta unhas cifras que a colocan entre as CC. AA. onde a competencia real na prestación do servizo de telefonía fixa está máis avanzada. Volveremos sobre este máis adiante, xa que a figura 2 non discrimina (dentro do resto de operadores) entre os que prestan o servizo de xeito indirecto e os que acceden coa súa infraestrutura ás centrais de conmutación de Telefónica.

\section{Banda larga con soporte físico}

No que atinxe ás infraestruturas de Internet con soporte físico, a finais de 2013 as solucións xDSL ${ }^{2}$ imperaban, aínda que a significativa presenza no mercado dos operadores de cabo fixo que se incrementase de xeito sensible o número de conexión híbrida cabo coaxial e fibra óptica, $\mathrm{HFC}^{3}$, que permiten o despregamento de redes de banda larga. Recentemente estase comezando, a partir das grandes cidades, a advertir tamén o despregamento das conexións de moi alta velocidade da man da fibra óptica ata o fogar $\left(\mathrm{FTTH}^{4}\right)$.

Por tecnoloxías, xDSL é maioritaria na banda larga en España, cunha penetración de 20 liñas por cada 100 habitantes, a distancia das 4,6 liñas por cada 100 habitantes do cabo, e as 1,3 liñas por cada 100 habitantes do FTTH. Cómpre salientar que, aínda que o número de liñas contratadas de fibra ata o fogar apenas é medible nalgunhas CC. AA., os accesos FTTH instalados chegaron en 2013 a case 7 millóns, dos que máis do $60 \%$ se contabilizan entre Madrid e Barcelona. Na figura 3 presentamos o detalle da penetración da banda ancha fixa nos tres tipos de accesos (xDSL, HFC e FTTH).

2 DSL designa a unha familia de tecnoloxías que fornecen acceso a Internet mediante unha conexión dixital sobre as liñas da rede de telefonía básica conmutada.

${ }^{3}$ A diferenza das redes de cabo para distribución de sinal de televisión, CATV, nas que a transmisión é unidireccional (desde a central ata os subscritores), en HFC, sobre o soporte híbrido de cabo coaxial e fibra óptica, a rede é bidireccional. O nome é un acrónimo da denominación en inglés Hybrid Fiber Coaxial.

${ }^{4}$ As tecnoloxías FTTx (Fiber To The -), sobre fibra óptica, utilizan sistemas de distribución ópticos (normalmente ata o fogar, FFTH) para a prestación de servizos avanzados. O futuro destas tecnoloxías está fóra de discusión xa que a velocidade de comunicación vai estar por moito tempo limitada polos equipos terminais dos usuarios e non pola fibra. Con FTTx pódese aspirar arestora a velocidades por riba de $1 \mathrm{Gbps}$. 
Figura 3. Penetración da banda larga fixa

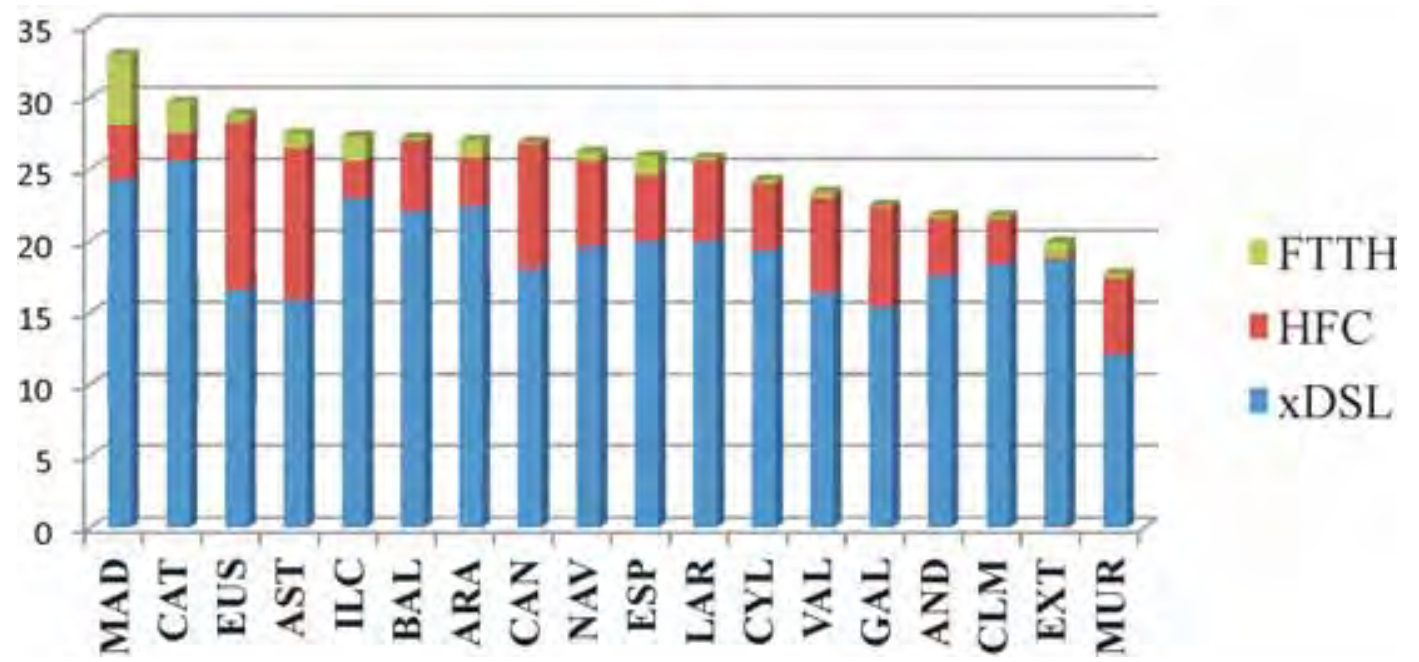

Fonte: CNMC, informe anual sobre as telecomunicacións 2014.

A figura 4 indica con claridade que non hai unha asimetría entre os datos de acceso á banda larga e a porcentaxe da poboación, aínda que, como é razoable, os datos de acceso están un pouco mellor correlacionados coa riqueza, medida en porcentaxe do PIB español. Pode verse na segunda das gráficas incluídas na figura 4 que o PIB explica case o $95 \%$ da variación no acceso, polo que todas as CC. AA. se sitúan practicamente sobre a recta de regresión.

Figura 4. Número de liñas NGA por CC. AA. en 2013 e porcentaxe da poboación/PIB de España
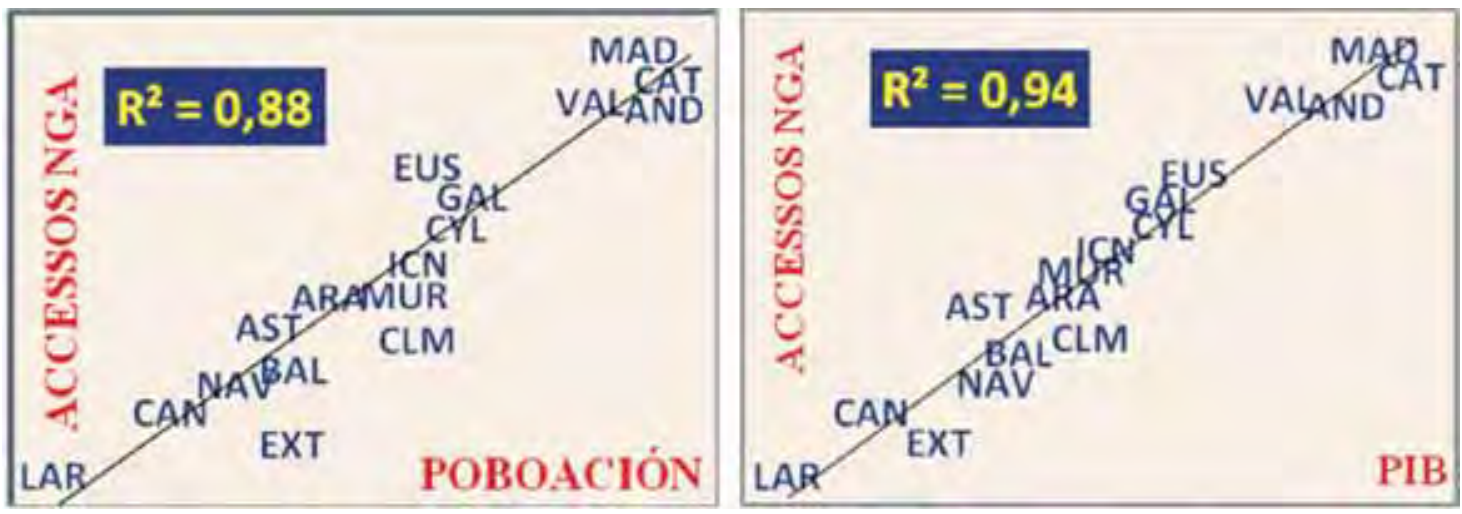

Fonte: CNMC, informe anual sobre as telecomunicacións 2014 para os datos de acceso, INE para os datos de porcentaxe da poboación e do PIB. Regresión, elaboración propia.

En todo caso e como se pode ver na figura 3, a penetración da banda larga en Galicia aínda admite grandes marxes de mellora, en particular no que atinxe ás conexións de maior velocidade. Cómpre salientar, non obstante, que a infraestrutura instalada en Galicia permite esas marxes de mellora, como vemos na figura 5: o número de liñas NGA instaladas (fundamentalmente híbridas coaxial e fibra óptica, HFC, de novo debido ao impacto da presenza do operador de cabo) en Galicia correspóndese co tamaño da comunidade autónoma. 
Figura 5. Número de liñas NGA por CC. AA. en 2013

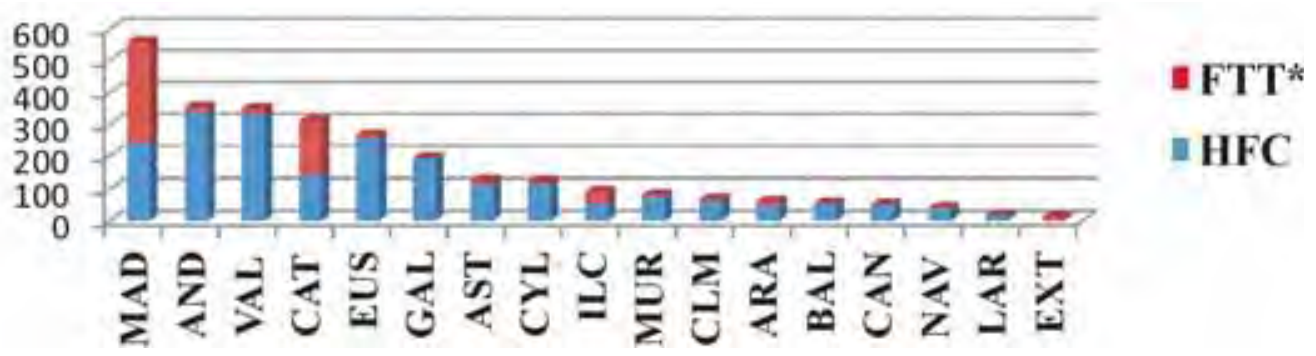

Fonte: CNMC, informe anual sobre as telecomunicacións 2014.

\section{Bucle desagregado}

A conexión ADSL sobre a liña telefónica convencional ou liña de abonado, directa e desagregada, permítelles a todos os provedores ofrecer velocidades máis altas a prezos competitivos. A desagregación do bucle de usuario do propietario da rede (usualmente Telefónica) esixe que os provedores dispoñan da súa propia rede ata a central da que depende o subscritor e dos dispositivos que permiten xestionar os servizos prestados sobre a conexión física (par de fíos de cobre) entre a central e o subscritor, que segue a ser propiedade de Telefónica.

A diferenza do bucle desagregado, os accesos indirectos, xa que logo non desagregados, son aqueles en que o operador que posúe a rede xestiona a relación entre a central e o subscritor, e pode facer de grosista, alugando o servizo ADSL a outro operador. Mentres non chegou o momento da fibra óptica, xa na década en que andamos, o número de enlaces desagregados constituía un indicador moi fiable do estado da liberalización das telecomunicacións en cada comunidade autónoma, ou, dito doutro xeito, das oportunidades que se lles presentaban aos usuarios polo incremento da competencia real entre operadores de servizos de telefonía e Internet.

Na figura 6 vemos a situación de Galicia no contexto español. Galicia ocupa a posición 11 entre as 15 CC. AA. analizadas, a case 15 puntos porcentuais da media española de desagregación do bucle de subscritor, o que indica que a competencia sobre as redes de Telefónica aínda está un pouco lonxe da que se observa noutras CC. AA. Non obstante, cómpre salientar que o operador de cabo $\mathrm{R}$ ten rede propia e non precisa da utilización do bucle de subscritor para a prestación dos seus servizos, polo que a competencia real en Galicia é maior do que este gráfico parecería apuntar.

Figura 6. Porcentaxe de bucles desagregados sobre o total, nas CC. AA

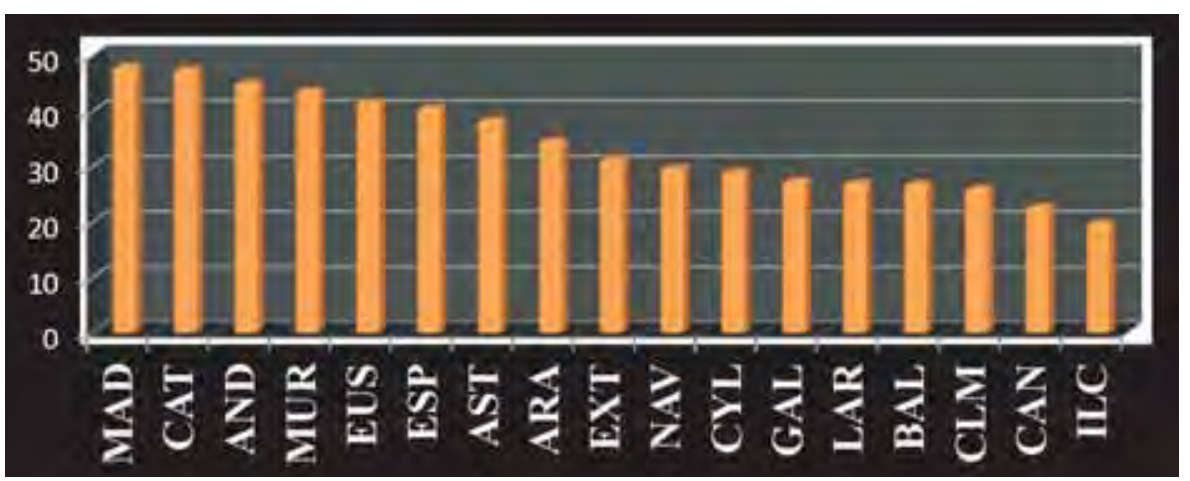

Fonte: CNMC, informe anual sobre as telecomunicacións 2014. 
De todos os xeitos, noutras dúas CC. AA. en que se dá unha forte competencia entre os operadores tradicionais de telecomunicacións e os operadores de cabo (Asturias e Euskadi), podemos advertir na figura 6 que a medida de desagregación do bucle está nos dous casos moi preto da media española, o que indica que efectivamente en Galicia a presenza temperá de $\mathrm{R}$ achicou as posibilidades de competencia do resto dos operadores, o que explica en certa medida as cifras pouco salientables en desagregación de bucle.

\section{Fibra Óptica}

Todo mudou nesta década. Malia, como se reflicte na figura 3, a porcentaxe de subscricións a liñas de alta velocidade (NGA) estar aínda nos seus albores, a fibra óptica goza xa dun venturoso presente que impulsa os operadores non a seguir incrementando os investimentos en equipos que permiten a xestión desagregada da conexión ADSL, senón a construír unha infraestrutura propia desde a que competir en pé de igualdade co operador dominante.

Os operadores de cabo entenderon hai tempo que o seu futuro dependía da posesión de infraestruturas propias de telecomunicación, e dirixiron o seu esforzo investidor á creación dunha rede propia desde a que ofrecen servizos de telefonía, datos e televisión. Os operadores de telecomunicacións alternativos a Telefónica non fixeron na década pasada ese esforzo investidor na creación de rede propia (fixa), polo que concentraron os investimentos na chegada ás centrais de Telefónica co fin de tirarlle máis partido á xestión integral das liñas fixas dos seus clientes. Así chegamos á presente década, na que Vodafone e Orange se decatan de que convén ter rede propia mais xa non é tempo de comezar a despregala, polo que deciden tirar polo camiño directo, a compra dun operador que si investira en rede propia nos primeiros anos do século XXI. Así se explica a présa en completar nestes dous últimos anos as compras de ONO, operador de cabo, por parte de Vodafone e de Jazztel (operador con rede propia) por parte de Orange.

A figura 7, en que se dá conta da aceleración da instalación de liñas NGA, complementa o que acabamos de analizar e discutir. Faise unha distinción na figura entre dous tipos de fibra: FTTH e FTTN. A primeira é a que completa o percorrido desde a central ata o fogar. A segunda chega moi preto do fogar, de feito chega á veciñanza, de aí o $\mathrm{N}$ de neighborhood. A figura mostra a evolución do parque de liñas NGA instaladas ${ }^{5}$ ao longo dos últimos tres anos.

Figura 7. Evolución trimestral do número total de liñas NGA (en millóns) instaladas en España

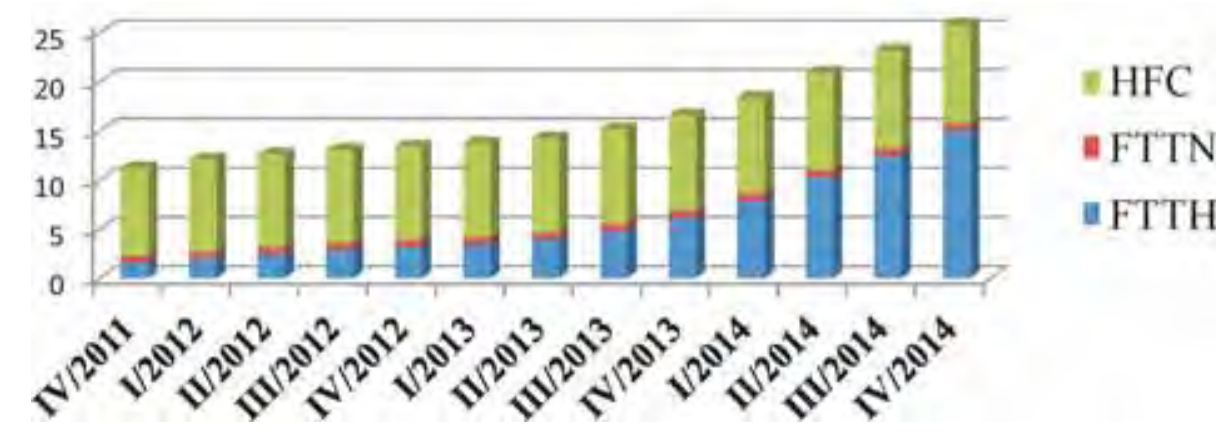

Fonte: CNMC (2015a), informe trimestral sobre as telecomunicacións (cuarto trimestre), 2014.

Como se pode comprobar, se a inicios de 2011 o número de liñas de moi alta velocidade aínda non era significativo, a finais do ano 2014 representaba máis dun 60 \% do total de liñas NGA, das que unha porcentaxe moi maioritaria eran liñas directas ata o fogar. Estes datos foron tomados do informe trimestral máis recente, que non

5 Un acceso instalado é un acceso que se pode activar e comercializar nun breve lapso de tempo (menos de 48 horas). 
contén información detallada por CC. AA. En todo caso, dada a aceleración claramente perceptible a partir de finais de 2013, data en que temos datos en detalle mostrados na figura 4, é de esperar que o despregamento en Galicia non sufrise ningún atranco.

No que atinxe ao número de subscritores de servizos de Internet de banda larga, entre febreiro de 2014 e febreiro de 2015 produciuse un incremento neto de case un millón,/ e xa é clara a tendencia cara á comercialización de liñas de fibra óptica ata o fogar en substitución de liñas DSL (CNMC 2015b), como se observa na figura 8.

Figura 8. Evolución mensual do número total de liñas NGA (en millóns) comercializadas en España

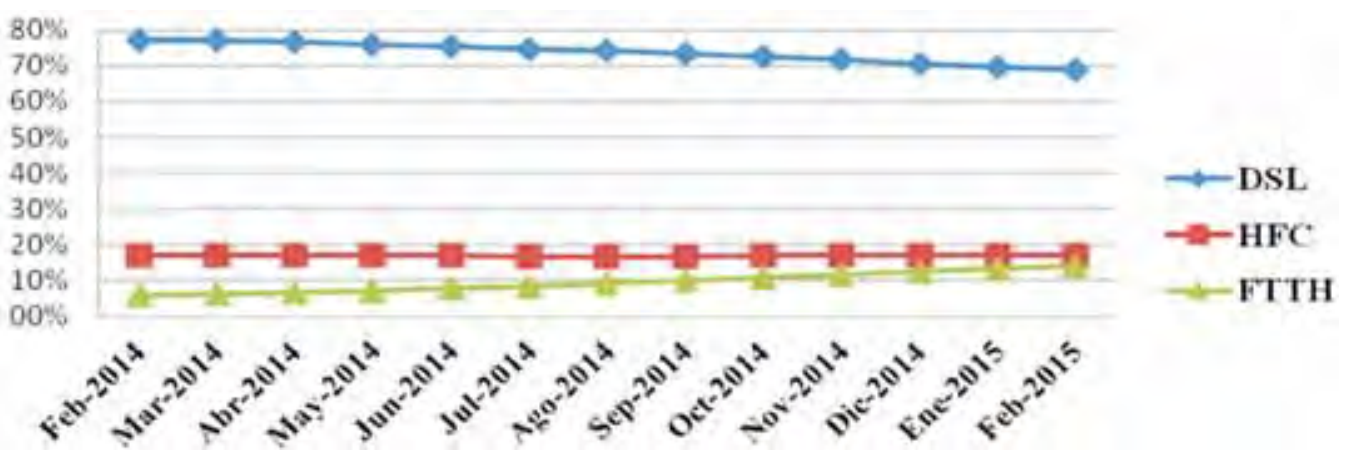

Fonte: CNMC (2015b), informe mensual sobre as telecomunicacións (febreiro 2015).

A principio de 2014, febreiro, había en España un total de 9,3 millóns de liñas de banda larga fixa e nada máis que 700 mil liñas FTTH. Pola contra, en febreiro de 2015 o número de liñas DSL reducírase a 8,8 millóns mentres que as de alta velocidade FTTH case se triplicaron, máis de 1,8 millóns de subscritores. Nese tempo, o número de subscritores utilizando tecnoloxías HFC (as dos operadores de cabo) mantívose practicamente na mesma cifra, o que dá idea do que indicabamos anteriormente: arestora a competencia está centrada non na xestión do bucle de cobre, senón na comercialización dos accesos de fibra óptica instalados ou adquiridos polos operadores de telecomunicación. Vista a tendencia claramente reflectida na figura 8, non é moi arriscado aventurar que con ocasión do seguinte informe, dentro de dous anos, as conexións de fibra óptica e híbrida van superar as vellas liñas ADSL.

\section{INFRAESTRUTURAS CON SOPORTE SEN FÍOS}

\section{Telefonía móbil}

A penetración da telefonía móbil segue moi por riba da telefonía fixa e mantén unha certa harmonía entre as CC. AA., agás o caso da Comunidade de Madrid, que está a moita distancia do resto das CC. AA. e, mesmo, contribúe a elevar de xeito significativo a media española. Na figura 9 podemos ver os datos de penetración, que deixan a Galicia nunha posición intermedia no contexto español.

Polo que respecta ao repartimento da telefonía móbil entre os diversos operadores, cómpre salientar que hai nada máis que 4 operadores en España con rede propia: Movistar, Vodafone, Orange e Yoigo. Os demais son operadores virtuais que utilizan as redes mediante convenios cos propietarios. Por exemplo, en Galicia R ofrece servizos móbiles mediante convenio con Vodafone.

A figura 10 dá unha idea de como se distribuían as cotas de mercado dos distintos operadores, onde baixo a epígrafe Resto figuran todos os operadores virtuais mais Yoigo, que aínda non tiña daquela nin o 5 \% do mercado de móbiles. 
Figura 9. Penetración da telefonía móbil en España a finais de 2013, detallada por CC. AA.

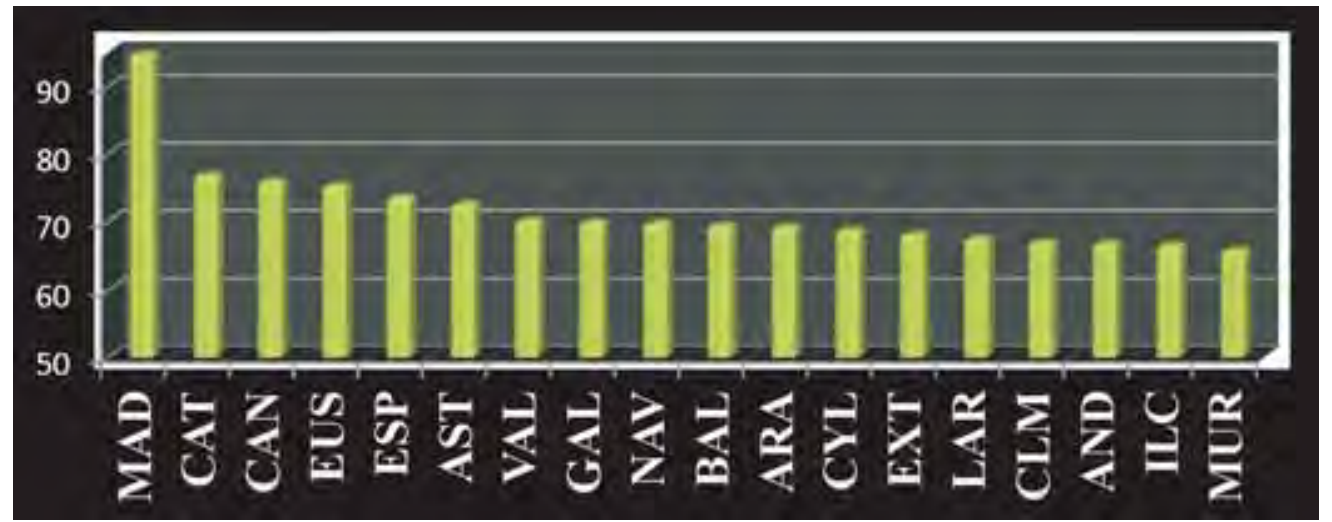

Fonte: CNMC (2014), informe anual sobre as telecomunicacións.

Figura 10. Cotas de mercado da telefonía móbil a finais de 2013, detallada por CC. AA. e operadores

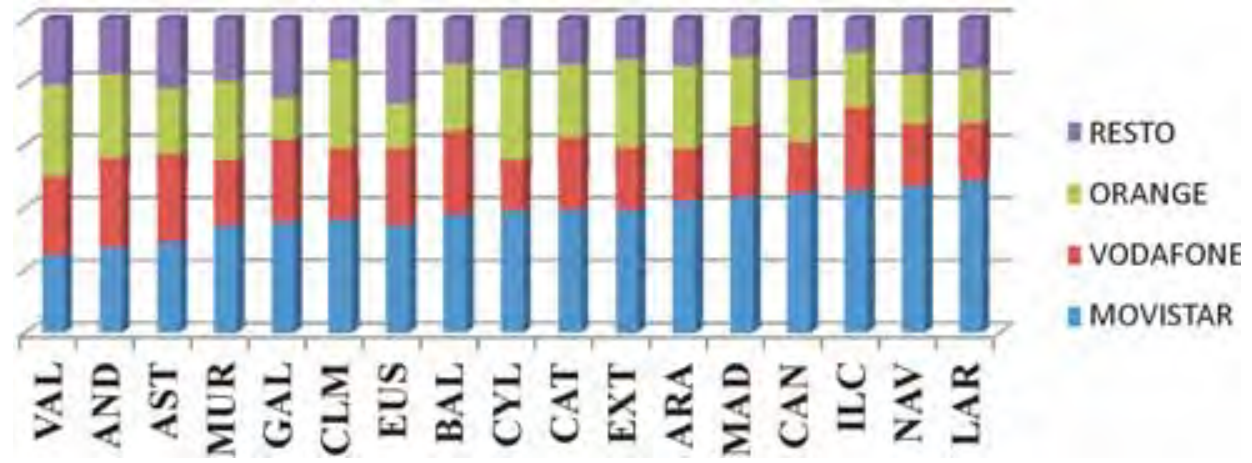

Fonte: CNMC (2014), informe anual sobre as telecomunicacións.

Podemos advertir a presenza da oferta de R en Galicia polo tamaño da parte máis alta da columna, correspondente ao resto de operadores, moi semellante á cota de Vodafone e ben por riba da cota de Orange. As porcentaxes de Movistar e Vodafone en Galicia son moi semellantes ás da media en España, a diferenza xa foi apuntada: mentres que, en xeral, en España Orange goza dunha cota de mercado semellante a Vodafone, de arredor do $25 \%$, en Galicia baixa a case un $15 \%$, en beneficio dos operadores virtuais, principalmente R.

\section{Internet móbil}

No que atinxe ás infraestruturas despregadas para fornecer cobertura móbil, estes últimos anos foron testemuña da transición entre as tecnoloxías $2 \mathrm{G}$ e 2.5G (asociadas aos diversos estándares coñecidos globalmente como GSM), ao UMTS, terceira xeración ( $3 G$ e 3.5G) de tecnoloxías sen fíos, a que utilizan os trebellos máis populares entre os internautas móbiles (PDA e smartphones). Con UMTS é posible o acceso a Internet desde os dispositivos celulares, o que abriu as portas da banda larga móbil, da que falaremos un pouco máis adiante. Recentemente, estase a despregar tamén infraestrutura de rede ligada a unha das tecnoloxías candidata ao estándar 4G, LTE, que pode fornecer velocidades de transmisión ao redor dos centos de Mbps. 
Xa que logo, unha medida do nivel de modernización das redes de telefonía e Internet móbil vén dada pola proporción de estacións base de cada unha das tecnoloxías mencionadas anteriormente. Na figura 11 podemos ver por CC. AA. a proporción de estacións con tecnoloxía 2G ou 2.5G (GSM e DCS), 3G (UMTS) e 4G (LTE). A agregación das proporcións de DCS e GSM indica o nivel de modernidade das estacións base. Canto menor é esa agregación, máis penetración teñen as liñas e servizos avanzados 3G e 4G. Galicia atopábase a finais de 2013 nunha posición intermedia no total de estacións avanzadas, mais un pouco atrasada na presenza da tecnoloxía LTE.

Figura 11. Porcentaxe de estacións base para telefonía e Internet móbil en España a finais de 2013, detallada por CC. AA. e por tipo de tecnoloxía

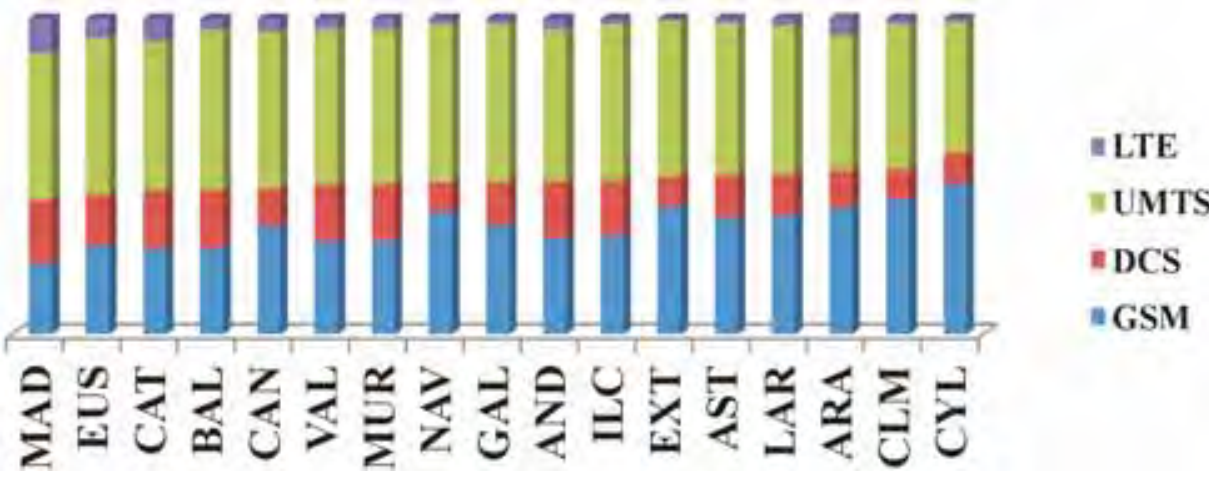

Fonte: CNMC (2014), informe anual sobre as telecomunicacións.

A figura 12 reflicte a situación de vangarda da banda larga móbil en España, que xa fora comentada na introdución ao presente traballo. En tan só 4 anos, a banda larga multiplicouse por 6 e chegou a unha penetración ao remate de 2014 do 78 \%, o que sitúa a España entre os países de vangarda europea no uso das tecnoloxías de Internet móbil.

Figura 12. Evolución do número de liñas de voz (en millóns) vinculadas a banda larga móbil ao longo dos últimos 4 anos

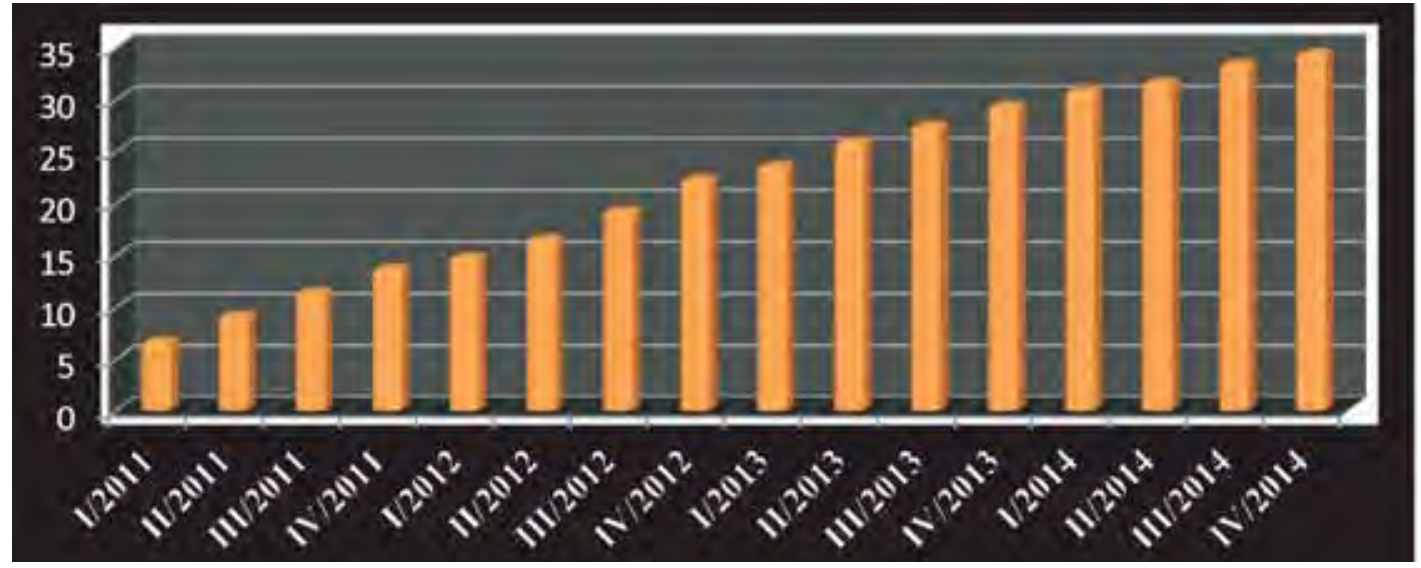

Fonte: CNMC (2015a), informe trimestral sobre as telecomunicacións.

Por operador a evolución foi moi semellante, como se pode ver na figura 13, o que indica que a competencia no mercado do móbil é a propia dun mercado maduro capaz de dar acubillo aos 4 operadores con rede propia. 
Figura 13. Evolución do número de liñas de voz (en millóns) vinculadas a banda larga móbil ao longo dos últimos 4 anos, detalladas por operador

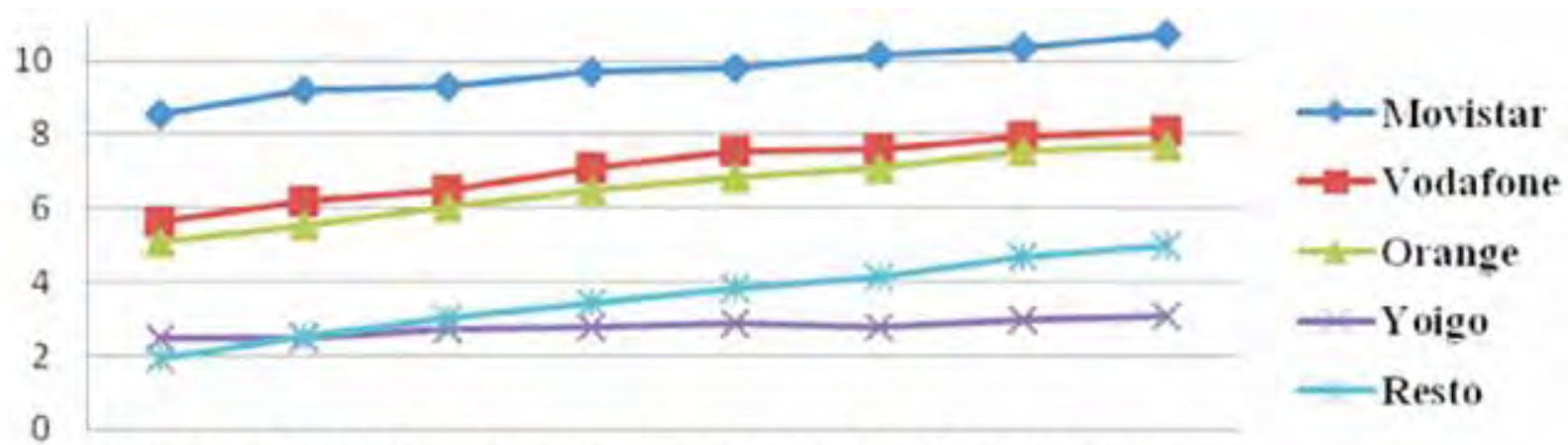

\section{I/2013 II 2013 III 2013 IV/2013 I/2014 II/2014 III/2014IV/2014}

Fonte: CNMC (2015a), informe trimestral sobre as telecomunicacións.

A CNMC aínda non inclúe no seu informe anual a información de banda larga móbil detallada xeograficamente, polo que non podemos indicar a evolución das liñas por CC. AA., a pesar de que a madurez do mercado apunta a un crecemento harmónico no que de novo Galicia estaría en posicións intermedias.

\section{CONCLUSIÓNS}

Dentro da iniciativa RIS3, estratexia global de innovación deseñada pola Comisión Europea co fin de mellorar a capacidade de Europa para xerar un crecemento intelixente e sustentable (European Commission 2012), a Axencia para a Modernización Tecnolóxica de Galicia deu prioridade, entre outras liñas de actuación, ao impulso ao despregamento de redes ultrarrápidas e á promoción do uso da banda larga móbil. En particular, o primeiro Plan de Banda Larga de Galicia semella ter dado resposta ao problema da fenda dixital, da que xa temos falado ao longo destes informes os pasados anos, achegando servizos de banda ancha a todo o país a finais de 2014 (Xunta de Galicia 2015).

Debido á presenza do operador de cabo $\mathrm{R}$, cunha longa traxectoria de investimentos en infraestruturas para dar cobertura aos núcleos urbanos, Galicia non quedou atrás na competencia real na prestación dos servizos de telefonía e Internet de alta velocidade a través das redes físicas.

Un efecto secundario da presenza dun operador de cabo en Galicia pode observarse nos datos de desagregación do bucle de abonado, que a finais dos anos 2000 constituía un potente indicador do grao de competencia, sobre todo no mercado de Internet fixa. A análise comparada apunta a que a decisión temperá de $\mathrm{R}$ de crear unha rede propia desanimou os competidores tradicionais do operador dominante, dado o tamaño do mercado galego, o que se reflicte no baixo índice de desagregación do bucle en Galicia en comparación coas demais CC. AA.

A presenza da oferta de $\mathrm{R}$ déixase notar tamén nas cotas de cada operador de telefonía móbil, a pesar de $\mathrm{R}$ prestar o servizo de xeito indirecto. As porcentaxes de Movistar e Vodafone son case as mesmas para Galicia e para a media española. Pola contra, Orange, cunha cota de mercado en España parella á de Vodafone, de arredor do $25 \%$, baixa en Galicia ao $15 \%$, en beneficio dos operadores virtuais, principalmente R. Aínda non temos os datos desagregados da Internet de banda larga móbil de moi alta velocidade, pero os datos relativos ás tecnoloxías $3 \mathrm{G} \mathrm{e}$ 3.5G (UMTS) apuntan a un desenvolvemento harmónico a medio prazo.

A partir do ano 2012, a fibra óptica converteuse no game changer, no factor dominante na toma de decisións dos operadores de telecomunicación. Os competidores de Telefónica xa non van investir en equipos que permiten a 
xestión desagregada da conexión ADSL: concluíron que é tempo de construír (mercar) unha infraestrutura propia desde a que competir en pé de igualdade co operador dominante, o que deu como resultado as fusións e absorcións entre operadores comentadas neste traballo. Os datos relativos a accesos contratados de fibra ata o fogar eran pobres na Galicia de finais de 2013 malia dispoñer de accesos instalados en harmonía co resto do Estado. A contratación dese tipo de servizos acelerouse nos últimos dous anos (figura 8), polo que é probable que os datos arestora en Galicia xa non indiquen atraso. Daremos conta no seguinte informe, cando dispoñamos de datos actualizados da CNMC. 


\section{REFERENCIAS BIBLIOGRÁFICAS}

CNMC (2014): Informe Anual de las Telecomunicaciones (http://data.cnmc.es/datagraph/files/Informe \%20Telecomunicaciones $\% 20 C N M C \% 202014$.pdf).

CNMC (2015a): Estadística Trimestral IV 2014 (http://data.cnmc.es/datagraph/jsp/inf_trim.jsp).

CNMC (2015b): Estadística Mensual IV 2014 (http://data.cnmc.es/datagraph/jsp/inf_men.jsp).

EUROPEAN COMMISSION (2012): Guide to Research and Innovation Strategies for Smart Specialisations (R/S 3) (http://s3platform. jrc.ec.europa.eu/c/document_library/get_file?uuid=a39fd20b-9fbc-402b-be8c-b51d03450946\&groupld=10157).

INE (2015a): Cifras de Población y Censos Demográficos (http://www.ine.es/inebmenu/mnu_cifraspob.htm).

INE (2015b): Contabilidad Regional de España. Base 2010. Tablas por comunidades autónomas. Serie 2010-2014 (http:// www.ine.es/daco/daco42/cre00/b2010/dacocre_base2010.htm).

XUNTA DE GalicIA (2015): Axenda Dixital de Galicia, Balance 2009-2014 (http://amtega.xunta.es/export/sites/amtega/descargas/150525-Balance-2009-2014-ADG.gal-v1.1.pdf). 


\section{OS GABINETES DE COMUNICACIÓN ONLINE EN GALICIA \\ Berta García Orosa \\ Universidade de Santiago de Compostela}

Doi: 10.17075/aceg.2016.008 



\section{ESTADO DA CUESTIÓN E METODOLOXÍA}

Galicia consolida o seu mapa de gabinetes de comunicación fundamentalmente durante os últimos 50 anos en consonancia cos países da contorna. En crecente expansión e con importante influencia na axenda mediática, os departamentos responsables da comunicación organizacional das diferentes entidades en Galicia profesionalizaron a súa actividade, ampliaron estruturas e funcións e institucionalizaron a comunicación cos diferentes públicos en novos sectores e entidades, como os concellos de menores dimensións, as ONG ou a Administración de Xustiza.

Nesta andaina, con pasos adiante a pero tamén con retrocesos, un dos factores potencialmente modificadores da esencia e das funcións dos departamentos de comunicación nos últimos anos foi a emerxencia dos gabinetes de comunicación online, da man do progreso da tecnoloxía. Baixo diferentes denominacións, os directores de comunicación galegos deseñaron estratexias que tiñan como elemento visible nun principio as salas de prensa dentro da web das entidades pero que, paulatinamente, diversificaron as súas funcións, actividades e presenzas no mundo dixital, e provocaron un novo eido de actividades e profesións dentro da tradicional comunicación corporativa.

Nos últimos informes da comunicación publicados polo Consello da Cultura Galega deixamos constancia da importancia crecente da actividade dos gabinetes tradicionais como ferramenta de información ou comunicación cos seus públicos e como un novo espazo de creación de identidade. No momento actual, a permanencia e evolución de Internet como lugar para a comunicación corporativa fan precisa a elaboración dunha panorámica da actividade dos departamentos de comunicación online en Galicia e este é o obxectivo principal do artigo: a radiografía das salas de prensa en Internet e algúns apuntamentos das tendencias ou retos no futuro próximo.

A xestión do contorno dixital é un dos principais temas estratéxicos dentro da comunicación organizacional reclamado dende o mundo profesional (Dircom 2008, VV. AA. 2013) e da academia (Andreu 2006, Castillo / Almansa 2005, Del Hoyo 2006 -no ámbito da empresa-, Moreno Sardà / Molina Rodríguez-Navas / Corcoy Rius 2013, Túñez / Sixto 2011 -nas administracións- ou no terceiro sector -Arroyo, Baños / Van-Wyck 2013, Nieto / Tapia Frade / Díaz Chica 2012-). Non obstante, a pesar de que os gabinetes máis activos optan dende un inicio por ter presenza na rede, ás veces son resistentes a cambios importantes no modelo de comunicación e, en moitos casos, adaptan as novas ferramentas tecnolóxicas aos vellos modos de comunicar. Os investigadores do campo describen a continuidade dun modelo de propaganda, persuasivo, de información unidireccional e asimétrica, máis que a procura dunha comunicación aberta (Dader / Cheng / Campos / Quintana / Vizcaíno-Laorga 2014: 116) que busca «permanecer, estar en la red» (Sánchez Duarte / Rodríguez Esperanza 2013) pero que non aproveita todas as potencialidades das novas tecnoloxías.

Para o noso informe, entendemos como gabinete de comunicación dixital ou online aquel departamento de comunicación responsable da planificación, implementación e avaliación da política comunicativa no contorno dixital. Polo tanto, inclúe no seu desenvolvemento a xeración de comunicación entre os seus diferentes públicos en Internet coa creación dun novo espazo de comunicación. Deste xeito, podemos ter un gabinete de comunicación básico ou 1.0 que emprega Internet como un elemento máis de comunicación sen modificar os elementos nucleares da comunicación e que se corresponde cun modelo unidireccional e asimétrico. Con diferentes opcións intermedias, no outro extremo está o gabinete transparente, comunicativo ou 2.0, que implica a participación do receptor de xeito asimétrico e bidireccional. Este departamento de comunicación provoca un novo modelo comunicativo que, na súa fase máis avanzada, comporta a creación dunha comunidade colaborativa que participa na elaboración de mensaxes. 
Así, poderiamos falar dun novo modelo comunicativo que denominamos CCCA con catro grandes actividades ou funcións: a) creación de contido; b) conversar; c) coñecer e investigar; d) actualizar contidos (García Orosa 2009).

No seguinte artigo buscamos a análise desta realidade en Galicia. A metodoloxía empregada, ademais da revisión bibliográfica pertinente, constou da análise de contido para a extracción de datos dos dous sectores con maior desenvolvemento en comunicación organizacional: as administracións públicas e as empresas. No primeiro caso analizáronse todas as institucións galegas e organismos oficiais autonómicos, as administracións provinciais e todos os concellos galegos. Para as escolmas das empresas analizadas seguimos os indicadores identificados no último informe Ardán (2014) que marcan as entidades que máis crecen en ingresos, as máis eficientes, as máis produtivas, as creadoras de valor e aquelas que posúen excelentes capacidades directivas: empresa gacela, empresa de alta produtividade, empresa xeradora de riqueza, empresa de alto rendemento e empresa ben xestionada.

Para o informe empregaremos de forma xenérica a denominación "gabinete de comunicación», aínda que, como indicamos en traballos anteriores, a realidade amosa un abano amplo de denominacións e funcións, en moitos casos limitados á relación coa prensa. Dentro deste, analizaremos o lugar deseñado para a relación cos medios de comunicación dentro das páxinas das entidades. Co fin de obter unha radiografía con perspectiva histórica analizáronse as seguintes variables: 1) presenza da sala de prensa dentro da web da entidade; 2) importancia da sala de prensa; 3) evolución do modelo de comunicación CCCA (contido, conversa, coñecemento e actualización); 4) instrumentos de información e comunicación; 5) evolución da adaptación á rede; 6) función específica de cada ferramenta de traballo en Internet; 7) redes sociais.

\section{CRECEMENTO CONTINUADO DE MODELOS TRADICIONAIS}

Os gabinetes de comunicación máis activos optaron, dende un inicio, por ter presenza na rede e comezar así o deseño dunha identidade online. Como podemos observar no gráfico 1 , aínda que o gran despregamento das salas de prensa dixitais se rexistra no segundo lustro do século XXI, xa existe unha porcentaxe importante de entidades galegas que escriben a súa identidade virtual dende antes de 2005. Neste seguimento temporal, falta valorar 0 impacto provocado pola crise dos últimos anos na comunicación organizacional dixital. A tendencia marcada cos datos que manexa este informe apunta cara a un descenso ou, polo menos, contención do crecemento das salas de prensa dixitais similar ao acontecido cos gabinetes tradicionais na década dos noventa do pasado século. Non obstante, pasada a crise económica, investigacións posteriores confirmarán ou desbotarán esta tendencia.

Gráfico 1. Ano de creación das identidades virtuais nas salas de prensa das empresas galegas

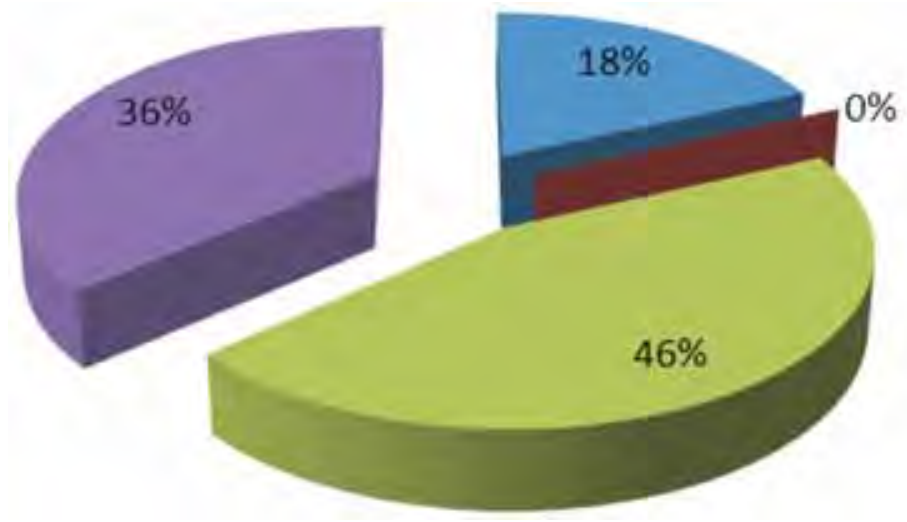

Antes do 2000

2000- 2004

2005-2009

2010- 2015

Fonte: elaboración propia. 
Por sectores, un 73,33 \% das principais institucións da Administración pública galega traballan cunha sala de prensa online, mentres que no caso das empresas é o 36 \% (vid. gráfico 2). Se incluímos os concellos, soamente un 7,6 \% da Administración pública galega conta con gabinete de comunicación dixital no momento actual, a maioría deles cunha importancia relevante ao figurar nun lugar privilexiado da primeira páxina.

O incremento rexistrado nos últimos anos é relevante xa que hai un lustro só o $6 \%$ das administracións públicas contaban cun departamento de comunicación dixital e un 22 \% no eido da empresa se ben non debemos obviar, como indicamos anteriormente, que a tendencia positiva na evolución cuantitativa da comunicación organizacional online parece ir máis lenta que noutros momentos da súa historia.

Gráfico 2. Salas de prensa nas organizacións

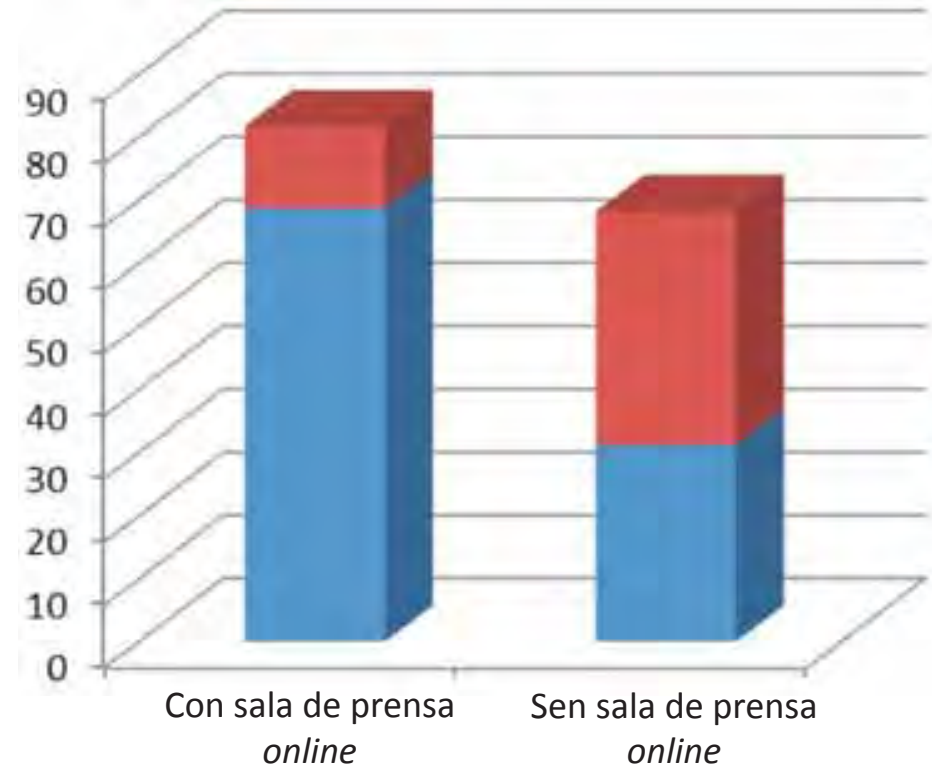

Empresas

Administración pública

Fonte: elaboración propia.

Dentro das tendencias sinaladas anteriormente para os países da contorna de Galicia, a presenza importante e crecente das salas de prensa online non está a implicar un cambio no modelo comunicativo na maioría dos casos, pola contra, consolidan e fomentan para os novos públicos os vellos procedementos de relación cos/coas receptores/as. O modelo de comunicación CCCA está lonxe de acadarse de forma xeral. Os gabinetes de comunicación están preocupados pola investigación dos públicos e empregan as novas ferramentas para esa función tradicional pero con novos instrumentos e non potencian excesivamente as outras pólas, como podemos observar a través do gráfico 3 sobre os instrumentos máis empregados. A transmisión de información sobre a compañía segue a ser, conxuntamente coas notas de prensa tradicionais, unha das ferramentas máis empregadas, o que implica o seguimento dun modelo de comunicación asimétrico e unidireccional. Neste eido, na creación e transmisión de contidos, existen leves progresos no emprego de dúas características propias da rede: hipertexto e, sobre todo, multimedia, pero, tal e como rexistramos en anteriores informes, cun fin en moitos casos de superposición de información e de acompañamento estético ao texto escrito principal. Os cambios indican, salvo excepción, máis información para os medios de comunicación e, sobre todo no caso das empresas, mellor xestión do arquivo e da recuperación.

No mesmo eido móvense as ferramentas deseñadas para ter unha relación ou conversa cos/coas receptores/as e que analizaremos no seguinte apartado. 


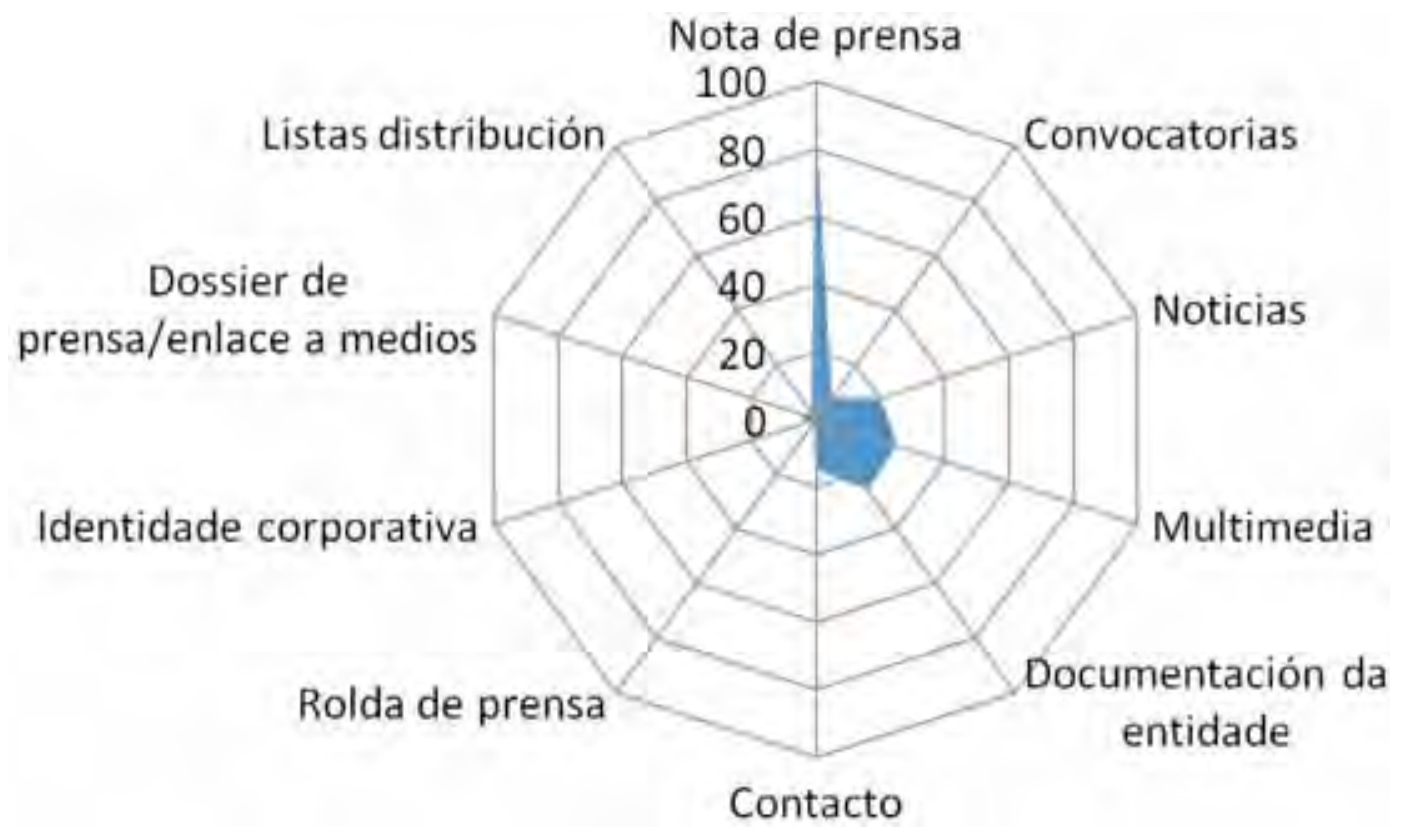

Fonte: elaboración propia.

\section{O RECEPTOR COMO PARTE DA MENSAXE: PARTICIPACIÓN E LINGUA}

Como vimos no apartado anterior, os gabinetes de comunicación fundamentalmente traballan creando contidos para un receptor eminentemente pasivo e os avances cara á web 2.0 ou que denominamos gabinete 2.0 son lentos. De xeito similar aos datos extraídos hai un lustro, o receptor das salas de prensa pode acceder a un primeiro nivel de interactividade a través da difusión da mensaxe recibida (sistemas de alerta, posibilidade de compartir e difundir, etiquetar), pero en poucos casos intervir na elaboración da mensaxe senón, en todo caso, traballar activamente na difusión dunha xa deseñada e pechada polo departamento de comunicación. Analogamente ao que acontecía en 2010, é moi escasa a aproximación ao gabinete 2.0 en todos os niveis: individual (alertas), de difusión ou para compartir (ferramentas que permiten xerarquizar) e as redes sociais (colectivo, simétrico ou asimétrico). Con diferenzas importantes na andaina dunhas e doutras entidades e estratexias dixitais diferenciadas, o gabinete 2.0 aínda permanece lonxe da maioría dos públicos galegos.

Con todo, hai innovacións que debemos destacar. Dentro das rexistradas nos últimos anos, as redes sociais considéranse nestes momentos unha das ferramentas máis empregadas neste camiño (A. Noguera / I. Peláez Sánchez 2013; Soler 2013), en moitas ocasións máis como instrumentos de difusión de mensaxes e márketing que como posibilidade real de conversa coa e co cidadán. Non detectamos unha estratexia común no seu emprego, máis aló do interese das entidades galegas nos últimos anos por figurar en todas aquelas redes sociais maioritarias nos hábitos do seu público obxectivo. De xeito similar ao resto de España, as redes sociais máis empregadas na comunidade autónoma galega en salas de prensa son Facebook e Twitter (vid. gráfico 4) e, dentro dos agregadores de contidos Meneame, Digg it e reddit. Convén, non obstante, destacar as diferentes estratexias marcadas polas entidades galegas, nas que resalta o interese de aproximación aos seus mercados internos e externos por parte das empresas que buscan a diferenciación na utilización de redes específicas do seu sector, como é o caso de StumbleUpon. 
Gráfico 4. Redes sociais máis empregadas. Porcentaxes
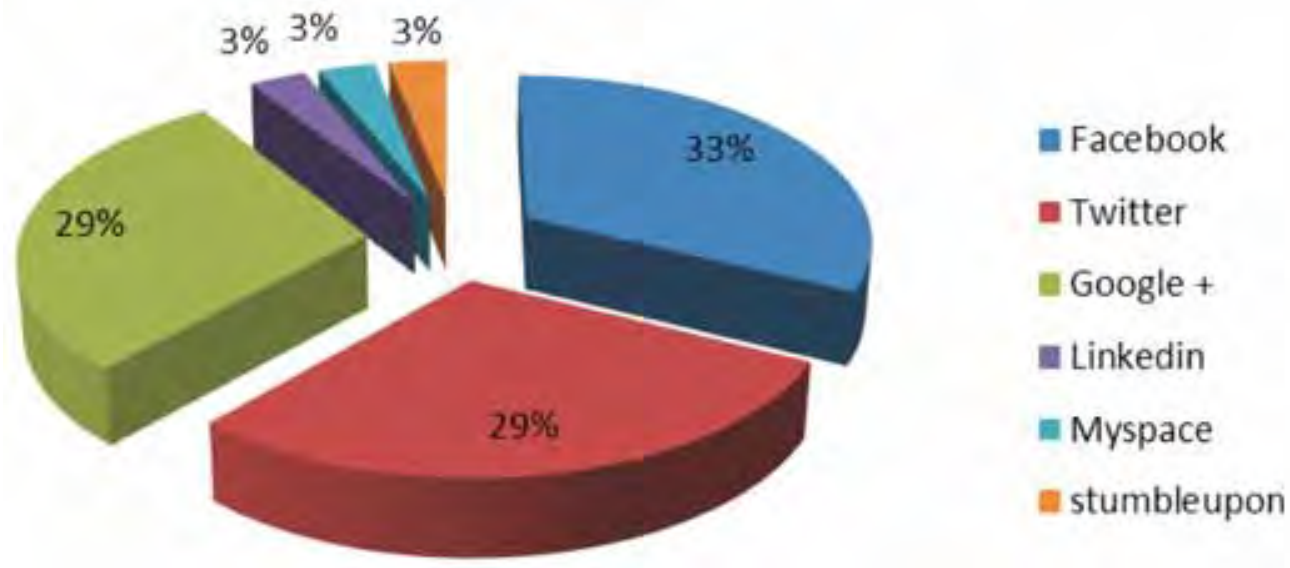

Fonte: elaboración propia.

Neste intento de aproximación ao receptor e, sobre todo, na potencialidade de participación e conversas reais con el, o emprego da lingua propia do usuario das salas de prensa convértese en fundamental. Neste sentido, constatamos que o emprego da lingua figura como unha das marcas diferenciais entre as entidades e sectores en Galicia, aínda que a gran maioría opta polo multilingüismo e a concesión ao receptor da posibilidade de escolla entre, normalmente, dúas ou tres linguas.

O emprego do galego no caso das empresas analizadas é residual (soamente figura nun 8,3 \% das páxinas, vid. gráficos 5 e 6). 0 castelán e o inglés son os idiomas maioritarios e conviven nos departamentos de comunicación en Internet coas linguas propias dos principais mercados estranxeiros das empresas: alemán e chinés (16,6 \% nos dous casos) e francés $(8,3 \%)$. O interese polos idiomas estranxeiros das entidades analizadas márcase especialmente cando remiten ao receptor ao tradutor de Google (presenza nun 8,3 \%). A escasa presenza do galego nas salas de prensa das entidades analizadas está acompañada dunha forte entrada do inglés en practicamente todas elas (case 9 de cada dez entidades analizadas).

O galego ten maior presenza na Administración pública, cun total de 96,15\%. Nas informacións remitidas polos departamentos de comunicación figura tamén a posibilidade de tradución ao castelán (nun 84,61 \%) e nun número residual de casos ao inglés (15,38\%).

Non se detectaron diferenzas importantes no emprego da lingua entre os distintos apartados da sala de prensa online nin entre esta e os outros apartados da web das entidades.

\section{RETOS NO CAMIÑO PARA UN NOVO MODELO COMUNICATIVO}

A evolución dos gabinetes responsables da comunicación cos diferentes públicos nas entidades galegas continúa a súa andaina coas tendencias marcadas en anteriores informes mais o incremento paulatino e paralelo da creación da súa identidade virtual. Unha das ferramentas empregadas para a construción desta presenza e actividade na rede son as salas de prensa online. Con deseños e estratexias adaptadas a cada unha das entidades, camiñan cara á creación de contidos e actividades específicas en Internet e coa visión posta nos últimos anos na participación da cidadanía. Non obstante, son escasos aínda os casos en que esta implementación de ferramentas tecnolóxicas implique un cambio substancial no modelo comunicativo asimétrico, unidireccional e xerárquico. 
Gráficos 5 e 6. Linguas empregadas nas salas de prensa en Galicia. Porcentaxes

\section{Administracións públicas}

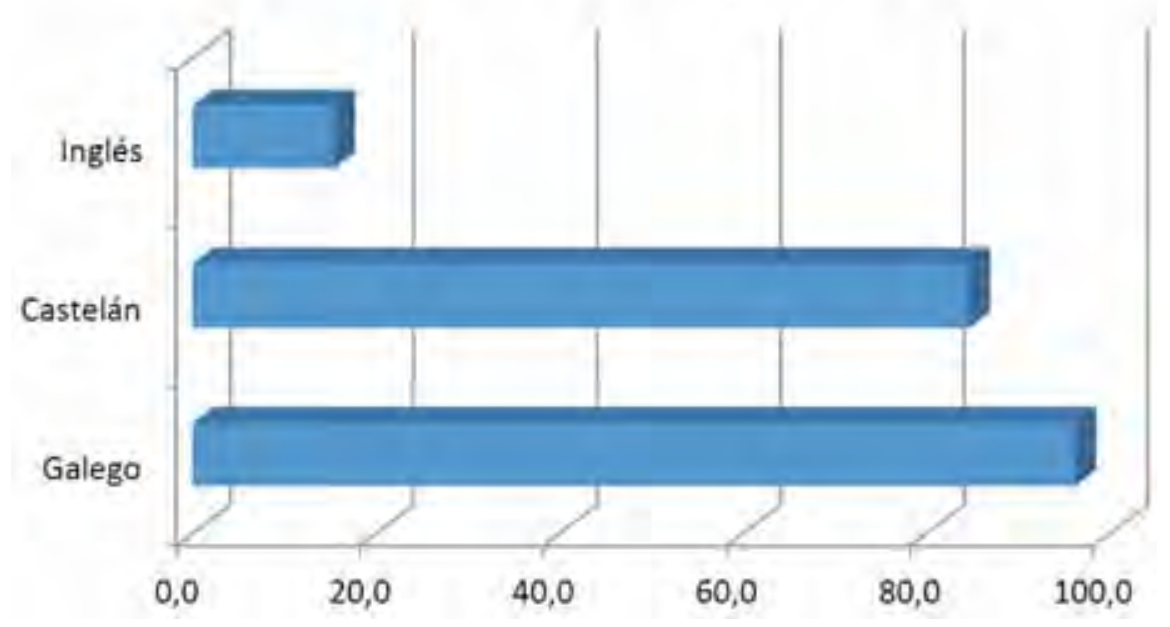

\section{Empresas}

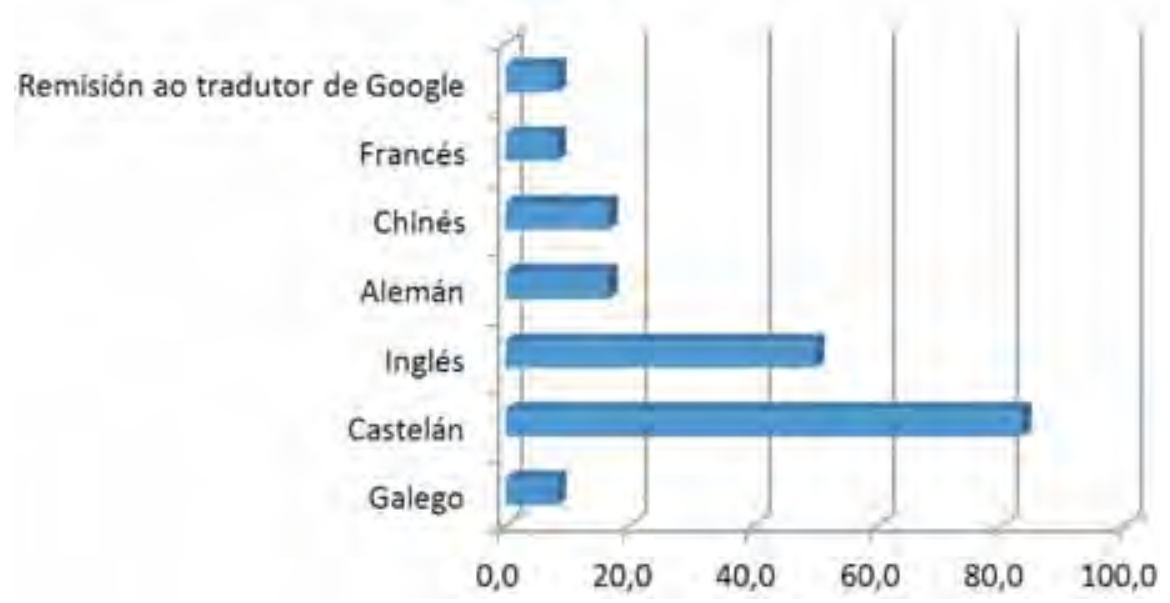

Fonte: elaboración propia.

As posibilidades técnicas están abertas en todos os apartados do modelo comunicativo CCCA e as estratexias, ferramentas e funcións deben estar deseñadas sempre de acordo co plan de comunicación xeral da entidade. Non obstante, apuntamos no gráfico 7 algúns retos ou tendencias. En relación co coñecemento e a investigación -unha das ramas máis traballadas polos gabinetes-, a tendencia actual apunta ao emprego da información para a elaboración de novas mensaxes conxuntamente coa actualización con periodicidades e contidos adaptados ás necesidades de cada receptor.

Na creación do contido, entre outros, podería beneficiar o éxito comunicativo a elaboración de mensaxes pensadas especificamente para a rede e, por suposto, para a súa difusión a través de medios de comunicación dixitais. Ademais, sería interesante en determinados departamentos de comunicación a posibilidade de realización de contidos colaborativos. 
Gráfico 7. Retos ou tendencias no modelo comunicativo CCCA

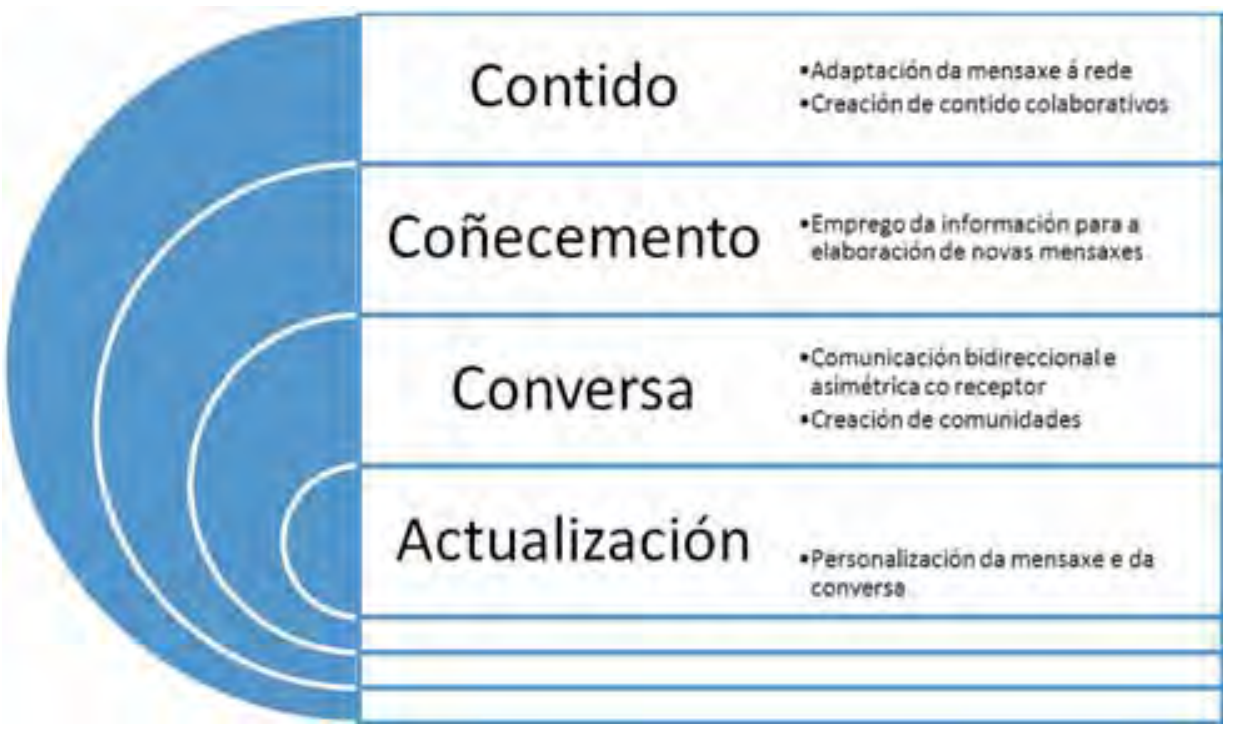

Fonte: elaboración propia.

Finalmente, unha das pólas máis reclamadas polos departamentos de comunicación e paralelamente menos empregada son as ferramentas destinadas á participación da cidadanía, á posibilidade de creación de conversa coa ruptura do modelo simétrico e tradicional e á creación de comunidades activas. 


\section{Referencias BibliográficAs}

ANDREU, A. (2006): «Internet, intranet e información: medida de la reputación corporativa», Telos: Cuadernos de Comunicación, Tecnología y Sociedad, 66, 95-98.

Castillo Esparcia, A. / A. Almansa Martínez (2005): «Relaciones públicas y tecnología de la comunicación. Análisis de los sitios de prensa virtuales», Organicom. Revista brasileira de comunição organizacional e relacões públicas, 3, $133-149$.

DAder, J. L. / L. Cheng / E. CAmpos / N. QuintAnA / R. VizCAíno-LAORga (2014): «Las webs de los partidos españoles en campaña electoral. Continuismo entre 2008 y $2011 »$ Trípodos, 1 (34), 115-152.

García Orosa, B. (2009): Gabinetes de Comunicación online. Claves para generar información corporativa en la Red, Zamora, Comunicación Social ediciones y publicaciones.

Hoyo, J. DEL (2006): «Nuevas redes y empresa: tecnologías web y su aplicación a la comunicación corporativa», Telos: Cuadernos de comunicación e innovación, 66, 79-82.

INFORME económico y de competitividad. Ardán 2014 (2014), Vigo, Consorcio da Zona Franca (http://www.ardan.es/ardan/ media/ejemplos/informeardangalicia2014.pdf) [última consulta: 20 de marzo de 2015].

Moreno Sardà, A. / P. Molina Rodríguez-Navas / M. Corcoy Rius (2013): «La información de las administraciones públicas locales. Las webs de los ayuntamientos de Cataluña», Revista Latina de Comunicación Social, 68, $502-528$ (http://www. revistalatinacs.org/068/paper/987_Bellaterra/21_Moreno.html) [última consulta: 20 de marzo de 2015]. D0I: 10.4185/ RLCS-2013-987/CrossRef link.

Nieto, B. G. / A. T. Frade / Ó. D. ChICA (2012): «La comunicación corporativa a través de las páginas web: el caso de las ONGs españolas», Vivat Academia, 120, 1-20.

Noguera Vivo, J. M. (2010): "Redes sociales como paradigma periodístico. Medios españoles en Facebook», Revista Latina de Comunicación Social, 65, 176-186 (http://www.revistalatinacs.org/10/art/891_UCAM/13_JM_Noguera.html) [última consulta: 20 de marzo de 2015]. DOI: 10.4185/RLCS-65-2010-891-176-186.

SÁnchez DuARTE, J. M. / S. RodríGuez EsPeranza (2013): «La extrema-derecha en Facebook. España 2000 y Democracia Nacional durante la campaña electoral de 2011 », Revista Mediterránea de Comunicación, 4 (1), 221-258 (http://mediterranea-comunicacion.org) [última consulta: 15 de marzo de 2015].

TúÑEZ, M. / J. Sixto (2011): «Redes sociales, política y Compromiso 2.0: La comunicación de los diputados españoles en Facebook», Revista Latina de comunicación social, 66, 1-25.

VV. AA. (2013): El Dircom del futuro y el futuro del Dircom, Madrid, Burson-Marsteller. 


\section{ANEXO}

A) Institucións Galegas e Organismos Oficiais: Presidencia da Xunta de Galicia; Vicepresidencia e Consellería de Presidencia, Administracións Públicas e Xustiza; Consellería de Facenda; Consellería de Medio Ambiente, Territorio e Infraestruturas; Consellería de Economía e Industria,Consellería de Cultura, Educación e Ordenación Universitaria; Consellería de Sanidade; Consellería de Traballo e Benestar; Consellería do Medio Rural e Mar; Parlamento de Galicia; Tribunal Superior de Xustiza de Galicia; Valedor do Pobo; Consello de Contas; Consello Consultivo de Galicia; Consello da Cultura Galega.

B) Administración provincial: Deputación de Pontevedra, Deputación de Ourense; Deputación de Lugo; Deputación da Coruña.

C) Concellos analizados: Concellos rexistrados na FEGAMP marzo 2015: Abadín, Abegondo, Agolada, Alfoz, Allariz, Ames, Amoeiro, Antas de Ulla, Aranga, Arbo, Ares, Arnoia, Arteixo, Arzúa, Avión, Baiona, Baleira, Baltar, A Baña, Bande, Baños de Molgas, Baralla, Barbadás, O Barco de Valdeorras, Barreiros, Barro, Beade, Beariz, Becerreá, Begonte, Bergondo, Betanzos, Os Blancos, Boborás, Boimorto, Boiro, A Bola, Boqueixón, Bóveda, Brión, Bueu, Burela, Cabana de Bergantiños, Cabanas, Caldas de Reis, Calvos de Randín, Camariñas, Cambados, Cambre, Campo Lameiro, Cangas, A Cañiza, A Capela, Carballeda de Avia, Carballeda de Valdeorras, Carballedo, O Carballiño, Carballo, Cariño, Carnota, Carral, Cartelle, Castrelo de Miño, Castrelo do Val, Castro Caldelas, Castro de Rei, Castroverde, Catoira, Cedeira, Cee, Celanova, Cenlle, Cerceda, Cerdedo, Cerdido, Cervantes, Cervo, Chandrexa de Queixa, Chantada, Coirós, Coles, Corcubión, O Corgo, Coristanco, Cortegada, A Coruña, Cospeito, Cotobade, Covelo, Crecente, Cualedro, Culleredo, Cuntis, Curtis, Dodro, Dozón, Dumbría, Entrimo, Esgos, A Estrada, Fene, Ferrol, Fisterra, Folgoso do Courel, A Fonsagrada, Forcarei, Fornelos de Montes, Foz, Frades, Friol, Gomesende, Gondomar, O Grove, A Guarda, A Gudiña, Guitiriz, Guntín, A Illa de Arousa, O Incio, O Irixo, Irixoa, Lalín, A Lama, Láncara, A Laracha, Larouco, Laxe, Laza, Leiro, Lobeira, Lobios, Lourenzá, Lousame, Lugo, Maceda, Malpica de Bergantiños, Mañón, Manzaneda, Marín, Maside, Mazaricos, Meaño, Meira, Meis, Melide, Melón, A Merca, Mesía, A Mezquita, Miño, Moaña, Moeche, Mondariz, Mondariz-Balneario, Mondoñedo, Monfero, Monforte de Lemos, Montederramo, Monterrei, Monterroso, Moraña, Mos, Mugardos, Muíños, Muras, Muxía, Narón, Navia de Suarna, Neda, Negreira, Negueira de Muñiz, As Neves, Nigrán, As Nogais, Nogueira de Ramuín, Noia, Oia, Oímbra, Oleiros, Ordes, Oroso, Ortigueira, Ourense, Ourol, Outeiro de Rei, Outes, Oza-Cesuras, Paderne, Paderne de Allariz, Padrenda, Padrón, Palas de Rei, Pantón, Parada de Sil, Paradela, O Páramo, A Pastoriza, Pazos de Borbén, Pedrafita do Cebreiro, O Pereiro de Aguiar, A Peroxa, Petín, O Pino, Piñor, A Pobra de Trives, A Pobra do Brollón, A Pobra do Caramiñal, Poio, Pol, Ponte Caldelas, Ponteareas, Ponteceso, Pontecesures, Pontedeume, Pontedeva, A Pontenova, As Pontes, Pontevedra, A Porqueira, O Porriño, Portas, Porto do Son, Portomarín, Punxín, Quintela de Leirado, Quiroga, Rábade, Rairiz de Veiga, Ramirás, Redondela, Rianxo, Ribadavia, Ribadeo, Ribadumia, Ribas de Sil, Ribeira, Ribeira de Piquín, Riós, Riotorto, Rodeiro, Rois, O Rosal, A Rúa, Rubiá, Sada, Salceda de Caselas, Salvaterra do Miño, Samos, San Amaro, San Cibrao das Viñas, San Cristovo de Cea, San Sadurniño, San Xoán de Río, Sandiás, Santa Comba, Santiago de Compostela, Santiso, Sanxenxo, Sarreaus, Sarria, O Saviñao, Silleda, Sober, Sobrado, Tordoia, Touro, Trabada, Trasmiras, Trazo, Triacastela, Tui, Val do Dubra, O Valadouro, Valdoviño, Valga, Vedra, A Veiga, Verea, Verín, Viana do Bolo, O Vicedo, Vigo, Vila de Cruces, Vilaboa, Vilagarcía de Arousa, Vilalba, Vilamarín, Vilamartín de Valdeorras, Vilanova de Arousa, Vilar de Barrio, Vilar de Santos, Vilardevós, Vilariño de Conso, Vilarmaior, Vilasantar, Vimianzo, Viveiro, Xermade, Xinzo de Limia, Xove, Xunqueira de Ambía, Xunqueira de Espadanedo, Zas. 
D) Empresas ben xestionadas en función dos ingresos de explotación

1. GOA-Invest, S.A. Grupo: Inditex.

2. SGL Carbón, S.A.

3. Cimpor Trading, S.A.

4. Mascato, S.A.

5. Pontevicus, S.L.

6. Borgwarner Emissions Systems Spain, S.L.

7. Hijos de Carlo Albo, S.L.

8. Atlántica Saga Ourense, S.L.U.

9. Ignacio González Montes, S.A.

10. Bimba \& Lola, S.L.

E) Listaxe de empresas gacela en función dos ingresos de explotación

1. Coren Agroindustrial, S.A.

2. Fashion Logistics Forwarders, S.A.

3. Conservas Selectas de Galicia, S.L.

4. Atunes y Lomos, S.L.

5. Instituto de Gestión Sanitaria, S.A.

6. SIEG-Vigo, S.L.

7. Ekoama, S.L.U.

8. Gestamp Wind Steel Galicia, S.L.

9. Estellez Galicia, S.A.

10. Martínez Otero Contract, S.L.

F) Listaxe de empresas de alto rendemento en función dos ingresos de explotación

1. Zara España, S.A.

2. Stradivarius España, S.A.U.

3. SGL Carbón, S.A.

4. Zara Diseño, S.L.

5. Kiddy's Class España, S.A.

6. Cogeneración del Noroeste, S.L.

7. Sarval Bio-Industries Noroeste, S.A.U.

8. Supervision y control, S.A.

9. Berska Diseño, S.L.

10. Massimo Dutti Diseño, S.L.

G) Listaxe de empresas xeradoras de riqueza en función dos ingresos de explotación

1. Industria de diseño textil, S.A.

2. Puentes y Calzadas infraestructuras, SLU

3. Obras, caminos y asfaltos, S.A.

4. Instituto de Gestión Sanitaria, S.A.

5. Armadores de Burela, S.A.

6. Casa Botas Vda. J. Martínez Blasco, S.L.

7. Mascato Salvaterra, S.L.

8. Compañía Española de Algas Marinas, S.A.

9. Geimex España, S.A.

10. Arce Clima Sistemas y Aplicaciones, S.L. 
H) Listaxe de empresas de alta produtividade en función do valor engadido por empregado

1. Sociedade Galega do Medioambiente, S.A.

2. Boiro Energia, S.A.

3. Inversiones Calde, S.L.

4. Diexpor, S.A.

5. Tag Formación, S.L.

6. B.M.C. Reformas, obras, rehabilitación, S.L.

7. Valiela, S.A.

8. Pesquera Inter, S.L.

9. Representaciones A. González, S.L.

10. Geimex España, S.A. 



\section{ACHEGA SOBRE A PUBLICIDADE EN GALICIA, 2012-2014}

Alberto Pena Rodríguez

Universidade de Vigo

Doi:10.17075/aceg.2016.009 



\section{PRESENTACIÓN}

No presente estudo sobre a publicidade en Galicia durante o bienio 2012-2014, abórdanse aquelas cuestións máis paradigmáticas ou que se consideran relevantes para a aproximación a este fenómeno, que debe examinarse sempre dentro do contexto nacional e internacional para comprender a súa dimensión en perspectiva.

Hai tres trazos que poderían definir de xeito simplificado o mercado publicitario galego actual: unha xa tradicional atomización da produción publicitaria, con decenas de pequenas axencias espalladas pola maioría dos concellos de Galicia; o debate sobre o uso irregular da lingua como medio de transmisión creativa, tanto por parte dos anunciantes como dos propios medios de comunicación galegos, impresos ou audiovisuais; e as políticas de investimento publicitario das institucións públicas galegas nas súas campañas de promoción dos servizos públicos. Neste último aspecto, a falta dunha lei de publicidade institucional que regule dalgún xeito as insercións publicitarias da Administración pública, fundamentais para a supervivencia de moitos medios, está a provocar unha polémica aberta entre o Goberno galego e as empresas informativas que integran a Asociación de Medios en Galego (AMEGA).

\section{OBXECTO DE ESTUDO E METODOLOXÍA}

Como xa se estudou en artigos anteriores sobre este mesmo eido da comunicación, delimitar o obxecto de estudo non é unha tarefa sinxela. A publicidade en Galicia abrangue múltiples aspectos relacionados coa produción creativa, ben dende unha dimensión estatística ou técnica, ou ben sobre o uso dos diversos soportes comunicativos (prensa, radio, televisión, Internet) ou os diferentes modelos persuasivos (comercial, político, cultural, corporativo).

Por outra banda, hai que ter en conta que non é o mesmo analizar a publicidade en Galicia que a publicidade en galego, pois son dous contextos que non sempre coinciden; ou que, incluso, se tivermos en conta o discurso publicitario en castelán que se difunde no noso país, poden ser mundos contrapostos ou que coexisten en paralelo.

Este artigo estrutura os seus contidos en tres partes esenciais: unha achega sobre o mercado publicitario dentro do contexto galego e español, con datos e cifras relevantes sobre as axencias de publicidade en Galicia; unha breve análise sobre os últimos aspectos relacionados co uso da lingua no discurso publicitario; e as tendencias actuais sobre a actividade publicitaria a nivel creativo e comercial. Nesta aproximación, utilízanse nomeadamente técnicas de tipo cualitativo, con cadros e elementos de tipo estatístico, provenientes de Infoadex ou Ardán, así como de información dispoñible en webs especializadas do sector.

\section{RADIOGRAFÍA XERAL DO MERCADO PUBLICITARIO ESPAÑOL E GALEGO}

Para achegarnos ao obxecto de estudo, é preciso que fagamos unha revisión dos datos que afectan o fenómeno publicitario no contexto español. Segundo as cifras do Instituto Nacional de Estatística de 2014, utilizadas para elaborar o último artigo de Infoadex, no exercicio de 2013 a cifra de investimento real estimado que rexistrou o mercado publicitario español situouse nun volume de 10 461,3 millóns de euros (a partir de agora M€), o que representou 
un decrecemento de $-3,7 \%$ sobre os 10 858,8 M€ que se acadaron no ano anterior, como se pode apreciar no cadro 1. A taxa de diminución en 2013 foi, xa que logo, do -8 \% con respecto ao ano 2012. Unha contracción do mercado que vén sendo constante dende o inicio da crise, coa excepción do ano 2010, no que se produciu unha mínima subida, que representou un espellismo á vista do imparable descenso nas cifras dende 2007, cando se acadaron uns $16108 \mathrm{M} €$, o 1,57 \% do PIB de España. A non ser Internet, que experimentou un crecemento do $1,8 \%$ (896,3 M€) grazas principalmente aos enlaces patrocinados, especialmente en Internet móbil, cun aumento do $51,3 \%$, en 2013 todos os medios convencionais tiveron caídas na súa cifra de negocio.

Cadro 1. Investimento publicitario sobre o PIB en España (2008-2013)

\begin{tabular}{lrrrrrr}
\hline Concepto & $\mathbf{2 0 1 3}$ & $\mathbf{2 0 1 2}$ & $\mathbf{2 0 1 1}$ & $\mathbf{2 0 1 0}$ & $\mathbf{2 0 0 9}$ & $\mathbf{2 0 0 8}$ \\
\hline PIB a prezos correntes & 1016654 & 1029002 & 1046327 & 1045620 & 1046894 & 1087 788 \\
\hline $\begin{array}{l}\text { Investimento medios } \\
\text { convencionais }\end{array}$ & 4261,0 & 4630,0 & 5497,1 & 5858,8 & 5630,9 & 7102,8 \\
$\begin{array}{l}\text { Investimento medios } \\
\text { non convencionais }\end{array}$ & 6200,3 & 6228,8 & 6555,9 & 7034,3 & 7078,1 & 7812,9 \\
\hline TOTAL & 10461,3 & 10858,8 & 12052,0 & 12893,1 & 12709,0 & 14915,7 \\
\hline PIB & 1,03 & 1,06 & 1,15 & 1,23 & 1,21 & 1,37
\end{tabular}

Fonte: Instituto Nacional de Estatística (Infoadex 2014).

Malia rexistrar un descenso do 6,2 \%, a televisión continúa a ser o primeiro medio por volume de negocio dentro do escenario dos medios convencionais, cun $40 \%$ da cifra de negocio total. Por segmentos, as televisións nacionais en aberto perderon un 6,4 \% de investimento publicitario (pasaron de 1643,9 a 1538,1 M€); as canles de pago subiron un 1,2 \% (de 43,1 a 43,6 M€); as televisións autonómicas caeron un 11,6 \% (de 126,8 a 120,4 M€); as televisións locais un 16,7 \% (de 1,5 a 1,3 M€). Internet, que acadou o 21 \% da cifra de negocio dos medios convencionais, consolida a segunda posición, por riba dos xornais diarios. 0 nivel de investimento publicitario nos diarios atinxiu o 15,6\% (662,9 M€), o que representa unha forte baixada do $13,5 \%$ con respecto ao ano anterior (766,3 M€). En canto á radio, que ocupa o cuarto lugar en 2013, posúe unha cifra de negocio do 9,5\% (453,5 M€), o que significa unha caída do $11 \%$ con respecto aos 453,6 M€ de 2012. E na publicidade exterior, o volume de negocio acadou o 6,6 \% (282,0 M€) do total dos medios estudados, cunha perda do 13,6\% en relación co último exercicio (326,3 M€). Nos últimos postos de investimento publicitario están as revistas, que acadan un 6,0 \%, pasan de 313,9 a 253,9 M€ (-19,1\%); os dominicais, que descenderon de 52,0 a 38,7 M€ (-25,6 \%); e o cinema, que tan só representou o 0,5\% do mercado global publicitario, ao baixar de 22,5 a 22,2 M€ (-10,1\%) (datos de Infoadex 2014).

Como o resto das comunidades, Galicia está a experimentar a contracción xeral do mercado publicitario en España dende o inicio da crise. De acordo coas cifras anteriores, o decrecemento do investimento publicitario parece que aínda non tocou fondo. Segundo se desprende dos resultados do último artigo que elaboramos para o Consello da Cultura Galega (Pena Rodríguez 2013) e do estudo extenso que publicamos co título de «O poder simbólico da publicidade en Galicia», dentro do volume colectivo O Capital da Cultura (Freixanes / Meixide 2010: 603-653), a produción publicitaria galega viuse sensiblemente afectada polas mudanzas da crise.

A desaparición traumática ou a drástica redución dos principais investidores publicitarios galegos, como Caixa Galicia, Caixanova, Pescanova, Fadesa, Caramelo ou a redución nos diferentes departamentos da Xunta de Galicia, representou un cambio substancial dentro do panorama dos anunciantes. Este refluxo publicitario, directamente vencellado ás mudanzas do mercado financeiro nacional e internacional, afectou seriamente a estabilidade e, 
incluso, a viabilidade económica de moitas empresas de comunicación galegas. Porén, esta situación coincidiu cun crecemento e consolidación do sector da produción publicitaria en Galicia, menos desenvolvido con respecto ao resto das comunidades españolas. Situación que se debe tanto ás reducidas cifras globais de investimento publicitario por anunciante como á falta de artellamento de estruturas empresariais sólidas que confíen na eficacia da comunicación comercial. No inicio da crise, a media nacional de investimento por anunciante situábase nos 150 $625 €$, mentres que en Galicia os anunciantes non gastaban de media máis de $20026 €$, a terceira máis baixa do Estado (Infoadex 2007), cifras que previsiblemente minguaron aínda máis na actualidade. Malia estes datos negativos, houbo anunciantes galegos, como os casos representativos de Gadis, Estrella Galicia ou a conserveira Calvo, que deron un salto cualitativo na promoción dos seus produtos con amplas campañas publicitarias, tanto a nivel nacional como internacional. E houbo tamén axencias publicitarias galegas que, dentro deste contexto de redución de beneficios, conseguiron acadar un prestixio cada vez maior e aumentar a súa reputación profesional.

Talvez, o caso máis paradigmático do éxito empresarial entre as axencias publicitarias sexa o de BAP Conde, que pasou de ter unha facturación de $10668014 €$ en 2008 a pouco máis de 6 millóns en 2013 (Informe Ardán 2010 e 2014), un 43 \% menos. Este dato negativo na cifra de negocio, extensible ao sector galego no seu conxunto con algunhas excepcións, coincide co período de maiores recoñecementos e premios acadados pola axencia coruñesa. En 2010, BAP Conde obtivo o prestixioso Premio á Eficacia Publicitaria da Asociación Española de Anunciantes pola campaña «Vivamos como galegos», de Gadis. Tamén foi a creadora do anuncio publicitario «Maloserá!», gañador do Premio de Prata á Eficacia en Comunicación Comercial. «Maloserá!» foi recoñecida por 8 de cada 10 galegos tras a difusión da campaña, cun grao de vencellamento coa marca do 70 \%. Só en Internet, o anuncio conseguiu 160000 descargas nos primeiros días da campaña. Segundo datos da propia axencia, converteuse, ademais, na máis vista da historia da publicidade en Galicia, con difusión en múltiples soportes publicitarios. Dende 2008, o traballo creativo de BAP Conde foi recoñecido noutros certames, como o Premio EFI e AMPE de Plata, o Premio de Publicidade en Galego do Consello Asesor de RTVE en Galicia e o Mestre Mateo de Produción Audiovisual. En total, a axencia coruñesa colleitou 35 premios nacionais e internacionais outorgados por anunciantes, medios de comunicación e os propios consumidores dende 2008. BAP Conde é a única axencia galega membro da Asociación Española de Agencias de Comunicación Publicitaria, que agrupa as principais axencias de publicidade de España.

A función creativa e a actividade promocional a través dos premios e recoñecementos públicos das campañas de comunicación comercial das axencias galegas parece que está axudando a aumentar a confianza dos anunciantes na eficacia publicitaria. A baixa cifra de investimento publicitario por anunciante en Galicia sinalada máis arriba posiblemente estea relacionada co descoñecemento e coa desconfianza nas técnicas da comunicación persuasiva. Polos datos dispoñibles, moitas empresas galegas aínda consideran a publicidade como un gasto en lugar dun investimento fundamental para lograr medrar e expandirse no mercado. Un estudo realizado en 2006 pola Confederación de Empresarios de Galicia (CEG) constataba que o 40,5 \% das entidades empresariais galegas non fan ningún tipo de investimento en comunicación publicitaria (CEG 2006: 45).

Como se vén sinalando nos estudos anteriores sobre este mesmo eido da comunicación galega (Pena Rodríguez 2010a, 2010b e 2013), o tradicional baixo investimento publicitario do sector empresarial galego e o seu agravamento por mor das consecuencias da crise financeira, non afectou de xeito sensible a estrutura e o número de axencias publicitarias galegas. Paradoxalmente, Galicia é a comunidade española con maior número de empresas de publicidade. En 2007, había 133 axencias publicitarias rexistradas, e no ano 2011, 132 (Pena Rodríguez 2013: 179). Segundo os datos do Informe Ardán 2014, que se nutre do Sistema de Análisis de Balances Ibéricos (SABI), o número de empresas rexistradas dedicadas á comunicación comercial en xeral (incluíndo actividades relacionadas coas relacións públicas e a produción gráfica de carácter publicitario) é de 584, aínda que algunhas delas pecharon ou están en proceso de liquidación. O balance da situación económica do sector a partir dos datos do SABI dá un 
importe neto na cifra de vendas de $85477 \mathrm{M} €$ en 2013, fronte aos $117607 \mathrm{M} €$ en 2009. Xa que logo, rexistrouse unha redución do 27,3 1 \% de facturación durante o período 2009-2013¹.

Nos últimos anos, debido á caída da facturación, moitas das axencias reduciron o número de empregados ou cambiaron o tipo de contrato laboral dos seus traballadores, mais a maioría seguiron funcionando. BAP Conde, por exemplo, pasou de ter unha cadro de persoal de 46 persoas en 2007, a 27 en 2013, como se pode ver no cadro 2, extraído do Informe Ardán 2014. A diferenza doutras, como a axencia internacional Elogia Media, especializada en márketing online, que consolidou durante estes anos a súa presenza en Vigo e pasou dun cadro de 26 empregados en 2010 (Informe Ardán 2012) aos 32 de 2013. Do ránking de facturación, pódese apreciar que hai 27 empresas que facturan máis de 1 millón de euros, mentres que en 2010 eran 35. En total, os datos de Ardán reflicten un panorama moi atomizado, con medio cento de axencias que teñen vendas superiores ao medio millón de euros e máis de medio milleiro de pequenas firmas situadas en diferentes concellos de Galicia, a maioría concentradas na área urbana de Vigo ou A Coruña. No cadro de datos que se reproduce a continuación engádense algunhas axencias desaparecidas recentemente:

Cadro 2. Ránking de axencias de publicidade e outras empresas de comunicación comercial galegas (con máis de medio millón de € de facturación)

\begin{tabular}{llrrr} 
Nome da axencia & Último ano dispoñible & Ingresos (M€) & Empregados \\
\hline 1. Externa Servicios Generales de Empresa SL & $31 / 12 / 2013$ & 6092 & 155 \\
\hline 2. Grupo Bap Conde SA & $31 / 12 / 2013$ & 6016 & 27 \\
\hline 3. Imaxe Intermedia SA & $31 / 12 / 2013$ & 5256 & 18 \\
\hline 4. Strategias de Medios Galicia SA (Extinguida) & $31 / 12 / 2008$ & 4144 & 5 \\
\hline 5. Canal Voz SL & $31 / 12 / 2013$ & 3964 & 11 \\
\hline 6. Elogia Media SL & $31 / 12 / 2013$ & 3888 & 32 \\
\hline 7. Reclam Publicidad Marketing y Artes Gráficas SA & $31 / 12 / 2013$ & 3765 & 16 \\
\hline 8. Avante Marketing y Medios, SL & $31 / 12 / 2013$ & 3143 & 10 \\
\hline 9. Ingenio Media SL & $31 / 12 / 2013$ & 2853 & 2 \\
\hline 10. Publigal SL & $31 / 12 / 2013$ & 2105 & 9 \\
\hline 11. Acanor Acabados del Noroeste Vigo SL & $31 / 12 / 2013$ & 1886 & 7 \\
\hline 12. Artenosa Publicidade SA & $31 / 12 / 2012$ & 1714 & 9 \\
\hline 13. Beeplan Spain SL & $31 / 12 / 2013$ & 1645 & 1 \\
\hline 14. Servicios de Publicidad Oia SL & $31 / 12 / 2013$ & 1541 & $\mathrm{~N} . d$. \\
\hline 15. Exclusive Seller SL & $31 / 12 / 2007$ & 1456 & 42 \\
\hline 16. Ecovigo Publicidad SL & $31 / 12 / 2013$ & 1454 & 8 \\
\hline 17. Innovacion Investigacion Desarrollo SL & $31 / 12 / 2011$ & 1294 & 5 \\
\hline 18. Verbas Publicidade SL & $31 / 12 / 2006$ & 1292 & 10 \\
\hline 19. Maxan SA & $31 / 12 / 2012$ & 1280 & 11 \\
\hline 20. Luis Ferreira Asociados SL & $31 / 12 / 2013$ & 1182 & 5 \\
\hline 21. Visual Trends SL & $31 / 12 / 2013$ & 1093 & 1 \\
\hline 22. Europublic Comunicacion SL & $31 / 12 / 2013$ & 1084 & 9 \\
\hline 23. Mediages SL & $31 / 12 / 2013$ & 1064 & 8 \\
\hline
\end{tabular}

\footnotetext{
1 O autor desexa agradecerlle a Håkan Casares Berg, do Observatorio da Cultura Galega do Consello da Cultura Galega, os datos extraídos do Sistema de Análisis de Balances Ibéricos e do Informe Ardán 2014 para a elaboración deste artigo.
} 
Nome da axencia

Último ano dispoñible

24. Quattro Industria Destiladora de Creatividad Publicitaria SL

25. Cares Marketing y Comunicacion SL

$31 / 12 / 2013$

26. Mega Publicidad Exterior SL (Extinguida)

$31 / 12 / 2007$

27. Idea Creatividad y Comunicacion SL

$31 / 12 / 2005$

28. Porto Valla Publicidad Exterior SL

$31 / 12 / 2013$

29. Expanding World SA

$31 / 12 / 2013$

30. Marketing Directo Publinor-O SL

$31 / 12 / 2007$

31. Bieitonova SL

$31 / 12 / 2013$

32. Agencia de Publicidad Galicia SL

$31 / 12 / 2012$

33. Hastoplay SL

$31 / 12 / 2007$

34. Ediciones Bolanda SL

$31 / 12 / 2013$

$31 / 12 / 2013$

35. Lago Empedrado SL

$31 / 12 / 2013$

36. Arco Área de Comunicación SA

$31 / 12 / 2006$

Ingresos $(\mathrm{M} €)$

Empregados

37. Corunesa De Publicidad SL (En Liquidacion)

$31 / 12 / 2001$

38. Exterior Galicia SA

$31 / 12 / 2013$

39. Modera Media SL

$31 / 12 / 2013$

40. Gallega de Publicidad y Diseño SA

$31 / 12 / 2010$

41. J\&J Publicidad y Comunicacion SL

$31 / 12 / 2013$

42. Alvi Publicidad SL

$31 / 12 / 2012$

43. Galicia Comunicacion G y C SL

$31 / 12 / 2013$

44. Perez Landeira SL

$31 / 12 / 2006$

45. Anonimo Advertising SL

$31 / 12 / 2013$

46. Cresva SL

$31 / 12 / 2007$

47. Galicia Media SL

$31 / 12 / 2013$

48. Transmedia Comunicaciones y Prensa SL

$31 / 12 / 2013$

$31 / 12 / 2009$

49. Oia Norte Servicios de Publicidad SL

$31 / 12 / 2007$

50. Asesores de Servicios Integrales de Publicidad SL

$31 / 12 / 2009$

$31 / 12 / 2013$

52. Comercializadora de Medios Grupo El Progreso SL

53. Occidente Diseño y Comunicacion SL

54. Mediapolis Galicia SL

$31 / 12 / 2013$

$31 / 12 / 2013$

55. Mercadotecnia Global SL

$31 / 12 / 2013$

56. Eaj48 Evolucion Multimedia SL

$31 / 12 / 2013$

$31 / 12 / 2009$

$1051 \quad 14$

$1044 \quad 4$

$1032 \quad 2$

57. Eloy Lozano Publicidad SL (Extinguida)

1021

0,999

0,947

0,934

0,923

0,918

0,917

0,877

$0,866 \quad 9$

$0,861 \quad 10$

$0,831 \quad$ N.d.

$0,824 \quad 8$

$0,758 \quad 24$

$0,749 \quad 7$

$0,742 \quad 5$

$0,723 \quad 4$

$0,686 \quad 6$

$0,684 \quad 5$

$0,656 \quad 4$

$0,586 \quad 1$

$0,586 \quad 4$

$0,580 \quad 4$

$0,566 \quad 15$

0,561

0,558

1

3

Fonte: datos de 2013 extraídos do Sistema de Análisis de Balances Ibéricos-SABI; Informe Ardán 2014.

\section{ELEMENTOS SOBRE A LINGUA GALEGA E A PUBLICIDADE}

Se o tecido empresarial galego amosa tradicionalmente unha certa desconfianza sobre a eficacia da publicidade como recurso estratéxico para o seu desenvolvemento e expansión comercial, á publicidade en galego en particular non lle presta demasiada importancia, malia as campañas para o uso do galego na comunicación comercial que veñen facendo o Foro Peinador, a Mesa pola Normalización Lingüística ou a propia Xunta de Galicia. Os datos que revela o 
estudo elaborado pola Confederación de Empresarios citado anteriormente son, neste sentido, moi esclarecedores. A maioría das empresas galegas analizadas neste artigo prefire empregar o castelán nas súas campañas nos diferentes soportes de comunicación. $080 \%$ dos anuncios publicados ou difundidos polas empresas da mostra, nos diferentes soportes de comunicación galegos, utiliza o castelán. A publicidade radiofónica, que acadaría un $30 \%$ do total, é na que máis se emprega a lingua galega; na televisión e Internet arredor dun $20 \%$ cada un; e na prensa non chega ao 15 \% (CEG 2006: 45-47). No caso da radio, posiblemente, a cifra veña determinada polo feito de que a Radio Galega non emite anuncios en castelán.

Como xa se afirmou en traballos anteriores, o emprego do galego na publicidade é máis rendible que o castelán por un conxunto de factores asociados a aspectos de carácter emocional e identitarios. A lingua galega é o recurso máis eficaz para conectar coa idiosincrasia galega, como veñen comprobando un conxunto de marcas, galegas ou alleas a Galicia, que comercializan os seus produtos no noso país (Telefónica, El Corte Inglés, Eroski, etc.) e utilizan o galego para promoverse (Pena Rodríguez 2010a, 2013). Un caso sintomático que pode servir de exemplo actual é o do aeroporto Sá Carneiro, na cidade de Porto, que vén desenvolvendo diversas accións publicitarias para captar clientes en Galicia por medio de mensaxes comerciais en galego en varios medios de comunicación do noso país. Baixo o lema «Oporto, o aeroporto de tódolos galegos», a campaña, difundida en varias cidades galegas, estimulou o incremento do número de usuarios galegos do aeroporto portugués, que actualmente acada o $10 \%$ do volume total de pasaxeiros. Nas propias instalacións, o aeródromo habilitou unha sala con xornais galegos e pantallas conectadas á Televisión de Galicia.

As cifras manexadas pola Compañía de Radio Televisión de Galicia (CRTVG) sobre o uso do galego nos anuncios emitidos pola canle entre 2009 e 2015 constatan un incremento do emprego da lingua galega por parte dos anunciantes cuxo domicilio social radica en Galicia, pasan do $71,5 \%$ ao $86,6 \%$. Porén, o número de insercións en galego caeu do 50,03 \% ao 47,8 \% no mesmo período. A CRTVG atribúe este descenso á desaparición dos anuncios nas canles de Televisión Española (TVE) e ao oligopolio existente na contratación das insercións, controladas por Mediaset e Atresmedia. 0 mesmo acontece coa contratación e comercialización de publicidade a través da web da CRTVG, cuxos anuncios se difunden maioritariamente en castelán debido á estrutura oliopolística do mercado, segundo a corporación audiovisual galega.

Este aparente retroceso no uso do galego no discurso publicitario da CRTVG, debe poñerse en relación con outros medios de comunicación e coa política lingüística da Xunta de Galicia (léase a Silva Domínguez 2005). A Asociación de Medios en Galego agrupa diversos xornais locais, a rede de emisoras municipais galegas e varios medios dixitais, que acumulan unha audiencia estimada de 300000 galegos e critican a falta de compromiso do Goberno autonómico para fomentar o galego. Segundo AMEGA, en 2014 os medios de comunicación en castelán levaron 9 veces máis axudas institucionais que os que empregan exclusivamente o galego. Esta asociación denuncia particularmente a contratación sistemática da publicidade institucional cos medios de comunicación que só usan o castelán. Por esta razón, AMEGA presentou no Parlamento, co apoio dos grupos políticos da oposición, unha proposta de Lei de publicidade institucional que dote de transparencia o repartimento de axudas públicas e de publicidade nos medios de comunicación de Galicia.

\section{TENDENCIAS DE FUTURO}

Para comprender cal vai ser a evolución do mercado publicitario en Galicia a curto e medio prazo, hai que situalo dentro do contexto español e internacional. O crecemento do investimento publicitario dependerá, como en anos anteriores, da situación financeira do tecido empresarial e da súa visión de negocio. No panorama galego non semella que vaia haber cambios substanciais na estrutura empresarial e na filosofía de negocio das axencias, a excepción de casos singulares como o de BAP Conde, con proxección fóra de Galicia. A produción publicitaria e a 
súa orientación estratéxica están cada vez máis enfocadas nos soportes dixitais. Polos datos que se desprenden do estudo de Infoadex 2014, a prensa é un soporte cada vez menos preferido polos anunciantes. As potencialidades e incentivos do mundo dixital para os consumidores están a transformar o mercado publicitario.

O uso cada vez máis masivo das redes sociais, de Internet e de todo tipo de soportes móbiles por parte do público así como a migración dos lectores de prensa en papel a soportes dixitais están modificando as políticas de comunicación comercial de grandes e pequenas empresas. Pola súa banda, as axencias galegas terán que ir adaptando as súas capacidades creativas a este tipo de contorno, que experimentará un crecemento sostido nos próximos anos. A principal asociación de empresas de publicidade dixital en España, IAB Spain (Interactive Advertising Bureau), que agrupa decenas de axencias de medios e creativas, buscadores, consultoras e anunciantes en soportes dixital, no seu relatorio anual sobre a situación do sector, destaca as seguintes tendencias para o futuro inmediato: o branded content, o branding, a compra programática ou RTB, a creatividade dixital interactiva, a sinalización dixital, o comercio electrónico, as aplicacións móbiles e as redes sociais corporativas.

\section{CONCLUSIÓN}

A publicidade en Galicia segue a sufrir as consecuencias da crise financeira, cun retroceso de máis do $27 \%$ no volume de facturación no quinquenio 2009-2013. Esta seria contracción do investimento publicitario afecta a composición dos cadros de persoal de moitas axencias galegas, que se viron obrigadas a reduciren o número de empregados, dentro dun sector enormemente atomizado formado por máis de cincocentas firmas, incluíndo todas as actividades da comunicación persuasiva. Mesmo así, algunhas empresas de comunicación comercial conseguiron consolidar a súa posición de mercado e acadar importantes recoñecementos nacionais e internacionais, como a axencia coruñesa BAP Conde. En 2014, había en Galicia 27 empresas do sector publicitario que facturaban máis de medio millón de euros segundo o Informe Ardán.

A maior parte das campañas que se están a crear nas axencias galegas e que logo se difunden nos medios de comunicación propios son realizadas en castelán. Malia as campañas institucionais para o uso do galego na publicidade e os datos que demostran a súa rendibilidade comercial, moitos anunciantes galegos seguen a desconfiar da súa eficacia. Na Televisión de Galicia, os anuncios en galego retrocederon 3 puntos no período 2009-2015, atribuíble neste caso ó oligopolio nas insercións publicitarias.

Por outra banda, a publicidade institucional segue a xerar polémica pola falta de transparencia na súa difusión por parte dos organismos públicos. Dende unha posición crítica coa utilización sistemática de medios en castelán nas campañas de comunicación pública, a Asociación de Medios en Galego avoga pola promulgación dunha lei que garanta un repartimento proporcional e equitativo entre os diferentes medios de comunicación. 


\section{REFERENCIAS BIBLIOGRÁFICAS}

Pena Rodríguez, Alberto (2013): "Os novos horizontes da comunicación publicitaria», en X. López García / M. Rivas Barrós / R. Aneiros Díaz (coords.), A comunicación en Galicia 2013, Santiago de Compostela, Consello da Cultura Galega, $171-186$.

Pena Rodríguez, Alberto (2010a): "O poder simbólico da comunicación publicitaria», en Víctor F. Freixanes / Alberte Meixide (eds.), O capital da cultura. Unha achega ás industrias culturais de Galicia, Santiago de Compostela, Fundación Caixa Galicia-Centro de Investigación Económica y Financiera, 599-653.

Pena Rodríguez, Alberto (2010b): «Os novos escenarios do sector publicitario galego», en Xosé López García / Rosa Aneiros Díaz (coords.), A comunicación en Galicia 2010, Santiago de Compostela, Consello da Cultura Galega, 147-156.

Ramallo, Fernando F. e Gabriel ReI Doval (1997): Vender en galego. Comunicación, empresa e lingua en Galicia, Santiago de Compostela, Consello da Cultura Galega.

Silva Domínguez, Carme (2005): Publicidade e lingua galega na prensa escrita. Estudo dun corpus composto por materiais de cinco xornais galegos, A Coruña, Universidade (tese de doutoramento).

\section{Informes e webs}

Estudio Infoadex de la inversión publicitaria en España, 2014. Dispoñible en: www.infoadex.es.

Informe Ardán 2009, 2010, 2011, 2012, 2013 e 2014. Dispoñible en: www.ardan.es.

O galego na empresa. Informe: Emprego do galego nas empresas. Dispoñible en liña en: www.normalizacion.ceg.es/files/ documentoestudo.pdf

Asociación Española de Agencias de Comunicación Publicitaria (AEACP). Dispoñible en: www.agenciasaeacp.es

Sistema de Análisis de Balances Ibéricos (SABI). Dispoñible en rede en: https://sabi.bvdinfo.com/sso.aspx?path=r... Interactive Advertising Bureau: www.iabspain.net

Axencia de publicidade BAP Conde: www.bapconde.com 


\section{AS RELACIÓNS PÚBLICAS EN GALICIA: ESTADO DA COMUNICACIÓN EMPRESARIAL E INSTITUCIONAL \\ Xosé Baamonde-Silva \\ Iván Puentes-Rivera \\ Xosé Rúas-Araújo \\ Universidade de Vigo}

Doi:10.17075/aceg.2016.010 



\section{INTRODUCIÓN}

A presente investigación analiza a evolución das relacións públicas en Galicia durante o último bienio, tanto no sector empresarial coma institucional, a partir da realización dunha enquisa online a un total de 34 responsables de comunicación.

Partindo da análise dos datos do anterior informe do ano 2013 e do contexto teórico e normativo da práctica desta disciplina, este estudo pescuda nas consecuencias da crise económica no exercicio da profesión durante os dous últimos anos, as estruturas, funcións e servizos ofrecidos polos gabinetes de comunicación galegos, así como as demandas de formación e recursos vencellados ás novas tecnoloxías, as tendencias observadas cara ao futuro e o uso do idioma galego.

Trátase dunha aproximación teórico-práctica, mais tamén dunha reflexión crítica, ao fío dos resultados, coa intención de achegar elementos para a súa discusión e posibles liñas de actuación e mellora, ante unha conxuntura en que os cidadáns son cada vez máis participativos e máis esixentes en materia de rendición de contas e transparencia.

\section{OBXECTO DE ESTUDO E METODOLOXÍA}

O obxecto do presente estudo é ofrecer unha «radiografía» cualitativa -aínda que a partir de resultados cuantificados- do sector das relacións públicas en Galicia a través das opinións dos profesionais do sector.

A técnica empregada para a recollida de datos é a de cuestionario online, con preguntas pechadas e abertas, a 6 directores de comunicación de empresas galegas pertencentes á asociación DIRCOM Galicia, xunto a 28 responsables de gabinetes de comunicación de institucións públicas galegas, entre as que se atopan 16 dos 20 concellos máis poboados de Galicia, as catro deputacións provinciais, 7 das 8 consellarías da Xunta de Galicia e mais a Secretaría Xeral de Medios.

\section{CONTEXTOS E ANTECEDENTES}

Os medios sociais e outros servizos de Internet permitiron a aparición dun novo cidadán dixital, máis crítico e con maiores posibilidades de trasladar as súas esixencias ás institucións e ás empresas. A cidadanía deixou de ser un suxeito pasivo e, a través da web social, tomou conciencia do seu poder e capacidade para organizarse e transmitir as súas reivindicacións.

Tanto as distintas administracións (Lei 19/2013) como as compañías privadas deben cumprir uns parámetros de transparencia e rendición de contas establecendo canles de información, diálogo e participación. Unhas e outras están inmersas no que algúns teóricos denominan o «combate pola atención». A atención converteuse nunha divisa tanto ou máis valiosa que a que se pode depositar nunha conta bancaria, nun factor esencial do éxito económico e social. 0 negocio flúe cara á atención e non hai cousa peor que pasar inadvertido, que ser invisible. Non obstante, nesta loita hai moita competencia e non se trata de lograr a visibilidade a toda costa, senón de forma axeitada. 
Neste escenario cobra unha importancia esencial o traballo dos relacións públicas, como responsables da xestión profesional da comunicación; da construción e consolidación de pontes de diálogo entre as organizacións e os diferentes públicos, e como profesionais encargados de lograr unha reputación acorde cos intereses dos devanditos organismos.

O traballo eficaz de relacións públicas é necesario para contribuír á construción de espazos de encontro entre as institucións, as empresas e a cidadanía. Para Solano (1999: 98), as relacións públicas xorden cando existe a necesidade de establecer conexións estables e duradeiras coa sociedade e que esta intercomunicación esixa uns coñecementos ou aptitudes e un esforzo susceptibles de constituír unha profesión autónoma.

\subsection{Rendición de contas, transparencia e relacións públicas}

A crise dos últimos tempos foi, ademais de económica/financeira, unha crise de confianza. A sociedade reclama a rendición de contas como un compromiso ético e de responsabilidade das organizacións respecto ás súas actuacións e ás consecuencias destas. A transparencia é o grao de información e a actitude con que se afronta esa rendición de contas. A recuperación da confianza social pasa por unha axeitada xestión da comunicación e os relacións públicas son unha fonte de información e non unha barreira para os medios (Adecec e Dircom 2015).

Neste contexto, as relacións públicas supuñan no pasado, e supoñen no presente, un esforzo deliberado, planeado e sostido para establecer e manter a comprensión mutua entre as organizacións e os seus públicos (Noguero 1995: 191).

Unha cuestión importante en toda rendición de contas é o papel que desempeña a sociedade civil. É desexable conseguir que se implique no proceso comunicativo, polo que é necesario facilitar o camiño elaborando unha información entendible, difundida por medio da Web 2.0 e das redes sociais e permitindo unha conversa permanente cos diferentes stakeholders.

Polo tanto, o traballo dos relacións públicas faise cada vez máis necesario para a construción dun diálogo crítico e interactivo entre as institucións, as empresas e as persoas. 0 potencial dos novos medios e as redes sociais para mellorar a sociedade e facela máis inclusiva e participativa, e por conseguinte máis democrática e máis xusta, é enorme e non pode ser desperdiciado. Administracións e representantes políticos e empresariais deben apostar por estas tecnoloxías non só para mellorar a información e a comunicación coa cidadanía, senón, sobre todo, para crear novas canles de deliberación e participación.

\subsection{0 sector das relacións públicas: datos dos últimos anos}

Os diferentes estudos que afondan na situación das relacións públicas en España nos últimos anos presentan un panorama ambivalente para o futuro da actividade. Este sector xera unha facturación próxima aos 400 millóns de euros (Torres y Carrera 2015), pero os datos máis actuais non amosan a recuperación das cifras acadadas no ano 2008, antes do desencadeamento da crise económica.

No caso galego, o último informe sobre comunicación organizacional publicado polo Consello da Cultura Galega (Míguez / Rúas 2013) incide no incremento cualitativo de funcións relacionadas co exercicio das relacións públicas, recoñecido por todas e todos os profesionais contactados, tanto de empresas públicas como privadas. 0 que contrasta coa eiva cuantitativa de persoal e de gabinetes de comunicación, amplificada pola crise, aínda existente en Galicia, en comparación coa evolución histórica experimentada no resto do Estado e nos países con máis tradición na práctica das relacións públicas. 


\section{RADIOGRAFÍA DO SECTOR EN GALICIA}

Expóñense deseguido os resultados máis relevantes das enquisas feitas entre os responsables de comunicación das institucións en empresas galegas analizadas.

\subsection{As relacións públicas nas institucións e nas empresas galegas}

A gran maioría dos departamentos de comunicación estudados son estables no tempo; máis da metade, case un $53 \%$, teñen unha antigüidade de máis de dez anos e tan só un 11,7 \% son de recente creación, ano 2011 ou posterior.

Trátase de gabinetes integrados na meirande parte dos casos por entre dúas e tres persoas (38,2 \%), aínda que tamén son numerosos os formados por unha soa persoa $(24,6 \%)$, caso de moitos dos concellos de tamaño intermedio, así como os constituídos por entre catro e seis profesionais $(26,4 \%)$, máis presentes estes na empresa privada que no eido institucional. Un tamaño que en xeral non se incrementou nin diminuíu significativamente nos últimos anos, posto que o 85,2 \% dos departamentos manteñen invariable o seu número de membros ao longo do bienio 2012-2014.

Os responsables destes gabinetes reciben habitualmente a denominación de responsables de comunicación (47\%), seguido do tradicional xefe de prensa (29,4\%). Semella, polo tanto, que se vai superando a visión reducionista de entender o labor destes profesionais como simples correas de transmisión cos medios de comunicación social e consolídase con forza a visión da comunicación integral, de contar con profesionais que se ocupen de xestionar a comunicación da empresa ou institución con todos os seus públicos, é dicir, relacións públicas. Esta tendencia é máis evidente no eido empresarial (66,6 \%) que no institucional (42,8\%).

Dito o anterior, sorprende, non obstante, que o termo relacións públicas non estea presente de modo explícito na denominación de ningún dos responsables de comunicación enquisados, agás nun único caso, o dunha das sete cidades. Confírmase, pois, o apuntado xa por numerosos estudos (Fernández-Souto / Puentes-Rivera 2014) que sinalan un problema de penetración terminolóxica das relacións públicas no noso país; mentres que a práctica delas está completamente estendida, a identificación e denominación propia da disciplina son moi baixas.

Este maior peso da comunicación integral vese tamén no feito de que no $94 \%$ dos casos os responsables de comunicación afirman participar na toma de decisións estratéxicas no seo da súa organización ou, polo menos, formular recomendacións que son tidas en conta pola dirección. Aínda así, un 20,5 \% dos profesionais seguen a identificarse como simples colocadores de notas de prensa.

No tocante a esas funcións que asumen, estas mantéñense maioritariamente estables nos últimos anos (58,8 \%), aínda que máis dun 35 \% afirma ter asumido novas funcións no bienio 2012-2014, derivadas fundamentalmente de realizar agora a xestión de redes sociais e o desenvolvemento de diversa actividade online.

\subsection{Percepción do estado das relacións públicas en Galicia}

Pasados xa vinte anos da implantación en Galicia dos primeiros estudos universitarios en comunicación e, particularmente, da titulación en Publicidade e Relacións Públicas, semella que a profesionalidade dos gabinetes de comunicación non interrompe a mellora xa apuntada por outros estudos, particularmente o último informe da comunicación publicado polo Consello da Cultura Galega (Míguez / Rúas 2013: 193-194).

Así (gráfico 1) máis dun 51,6 \% dos responsables de comunicación considera que a formación dos e das profesionais que traballan en Galicia é hoxe moito mellor do que era hai vinte anos e un 24,2 \% considera que esta é simplemente mellor, pero suficiente. Tan só un $24,2 \%$ a considera insuficiente, case vinte puntos menos que no informe de hai dous anos (Míguez / Rúas 2013: 194), e ninguén a considera peor. 
Gráfico 1. Percepción sobre a formación dos profesionais con respecto a hai vinte anos

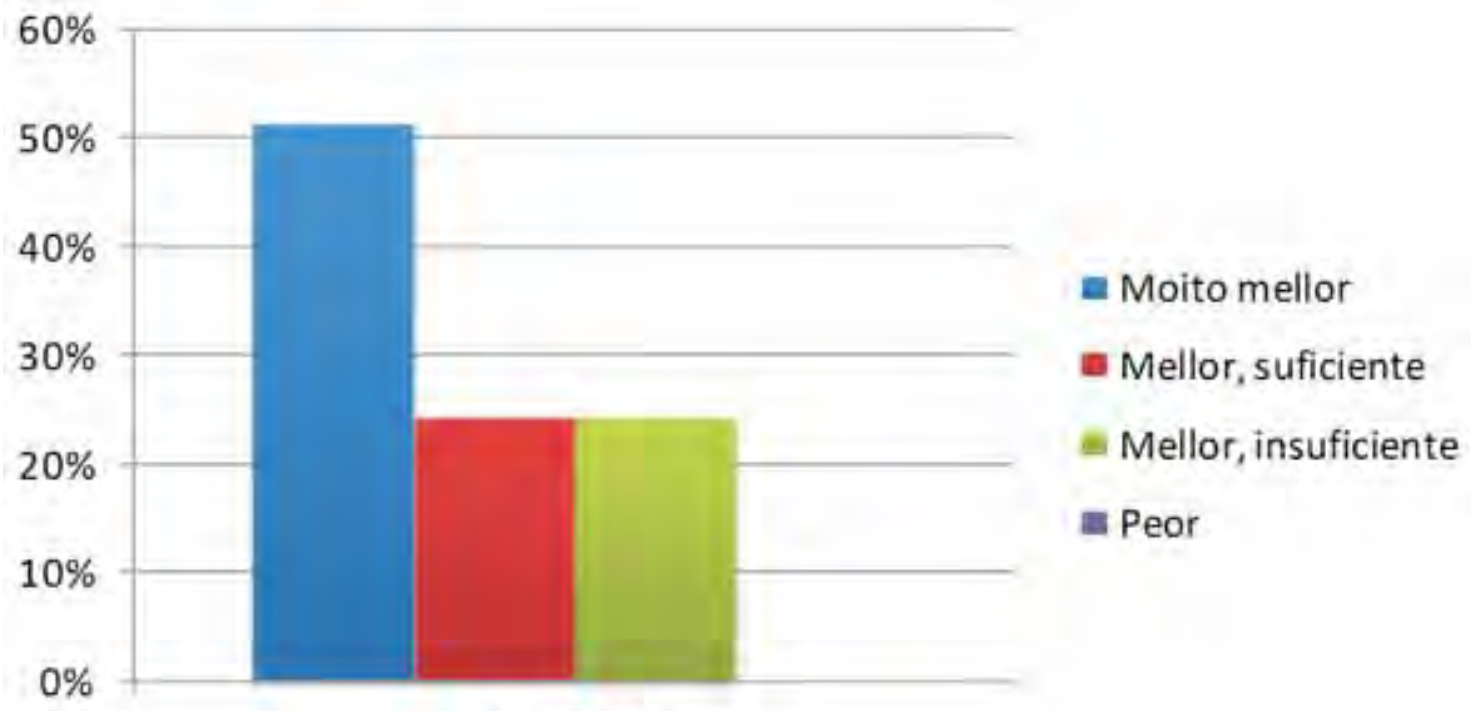

\section{Formación}

Fonte: elaboración propia.

Prodúcese tamén un salto cualitativo e positivo na valoración que os traballadores da comunicación fan da percepción que os responsables institucionais e empresariais teñen desta e da súa importancia. Así, practicamente un 61\% (60,6\%) dos enquisados, 30 puntos máis que no Informe de 2013 (p. 192), consideran que os empresarios e institucións comprenden e valoran a función da comunicación e das relacións públicas e están cada vez máis dispostos a investir nela. Un 30,3\% cren igualmente que eses responsables valoran e comprenden a comunicación, pero non están dispostos a incrementar o gasto e tan só un 9\% (fronte ao 54\% de 2013) considera que non se comprende ou valora axeitadamente esa función das relacións públicas, tal e como se ve no gráfico 2 .

Gráfico 2. Valoración da función da comunicación por parte dos responsables institucionais e empresariais

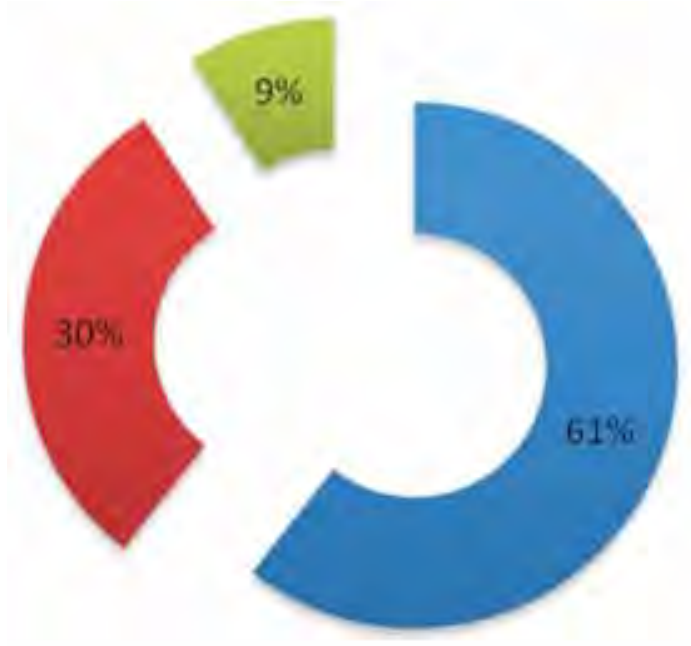

Valoran as funcións de comunicación e estân dispostos a investir máis

- Valoran as funcións de comunicación, pero non están dispostos a incrementar o investimento

- Non valoran as funcións da comunicación

Fonte: elaboración propia. 
No terreo negativo, igual que hai dous anos e con similares valores, segue a estar a percepción sobre a dimensión dos gabinetes de comunicación, que para un $64,7 \%$ é inferior ao desexable, fronte a un 35,2 \% que a considera suficiente.

\subsubsection{A regulación da comunicación e da publicidade institucional}

Ao preguntarlles aos e ás responsables de comunicación das institucións públicas galegas sobre a necesidade ou non de regular o exercicio (difusión, contratación...) da comunicación e a publicidade institucional, a resposta favorable a esta regulación é claramente maioritaria, un 96,4 \%, 8 puntos máis que no informe de 2013 (Míguez / Rúas 2013: 196). As diferenzas están simplemente en determinar que Administración se debe encargar de tal regulación, o Goberno de España (32,1 \%), a Xunta de Galicia (32,1\%) ou os concellos (32,1 \%).

Neste sentido, unha importante maioría dos profesionais (75\%) considera unha prioridade que se aprobe a Lei de publicidade institucional de Galicia, que acumula xa varios anos de atraso no Parlamento.

Unha porcentaxe similar, incluso lixeiramente superior (78,5\%), defende a necesidade dunha maior transparencia na contratación da publicidade institucional (facer públicos os contratos, establecer criterios obxectivos á hora de contratar publicidade nos medios...). Preguntados os enquisados polos criterios que deberían prevalecer á hora de contratar, as respostas maioritarias son fundamentalmente a difusión, a audiencia e o ámbito xeográfico do medio. Hai, incluso, un concello que propón algo que cualitativamente podería ser relevante, valorar que os medios teñan ou non persoal específico destinado a cubrir a información da zona.

\subsection{A crise e as relacións públicas en Galicia}

Tras sete anos de crise económica, os efectos desta sobre o eido da comunicación son percibidos en conxunto dun xeito negativo, aínda que a impresión maioritaria nestes momentos é a dun estancamento das súas consecuencias.

Así, o 41,1 \% dos enquisados considera que no período 2012-2014 eses efectos non variaron. Resulta significativo, non obstante, que o 38,2 \% considera que nese bienio as consecuencias se agravaron, fronte ao $20,5 \%$ que percibe unha diminución delas.

Uns efectos da crise que para o $58,8 \%$ son graves (47\%) ou moi graves $(11,7 \%)$, mentres que para un $41,1 \%$ son menos graves do agardable $(32,3 \%)$ ou simplemente leves $(8,8 \%)$. Uns datos que, como se pode ver no gráfico 3, contrastan cos do informe A comunicación en Galicia 2013 (Míguez / Rúas 2013: 195), no que a situación era cualificada de moi grave polo 37 \%, 26 puntos máis que na actualidade, aínda que tamén descende en dous puntos o número de persoas que perciben estes efectos como leves.

O presente estudo amosa tamén unha percepción da realidade claramente diferente entre o cadro laboral das institucións públicas e o das empresas privadas. Nestas últimas, todos os entrevistados perciben a situación como grave ou moi grave, mentres que no caso dos gabinetes das administracións a percepción da crise está repartida ao $50 \%$ exacto. A metade considera os seus efectos graves ou moi graves e a outra metade non tan graves ou mesmo leves, sete puntos máis que hai dous anos, sen que se observen grandes distincións nin por institucións nin por partido político á fronte destas.

As principais consecuencias da crise son a redución do investimento en comunicación (38,2\%), así como a redución de persoal ou a paralización de novas contratacións nos departamentos (23,5%). En todo caso, un $11,7 \%$ declara non ter padecido ningunha consecuencia por mor da crise.

No caso concreto das administracións públicas, máis da metade $(53,5 \%)$ reduciron o orzamento destinado á contratación de publicidade institucional. Neste contexto, o $67 \%$ dos responsables de comunicación afirman que nos últimos tempos se incrementou moito (25\%) ou algo (35,7\%) a presión sobre o seu gabinete por parte das empresas de comunicación na procura de axudas ou subvencións institucionais. Un $25 \%$ di que recibe hoxe a mesma presión que antes da crise. 
Gráfico 3. Evolución na percepción dos efectos da crise

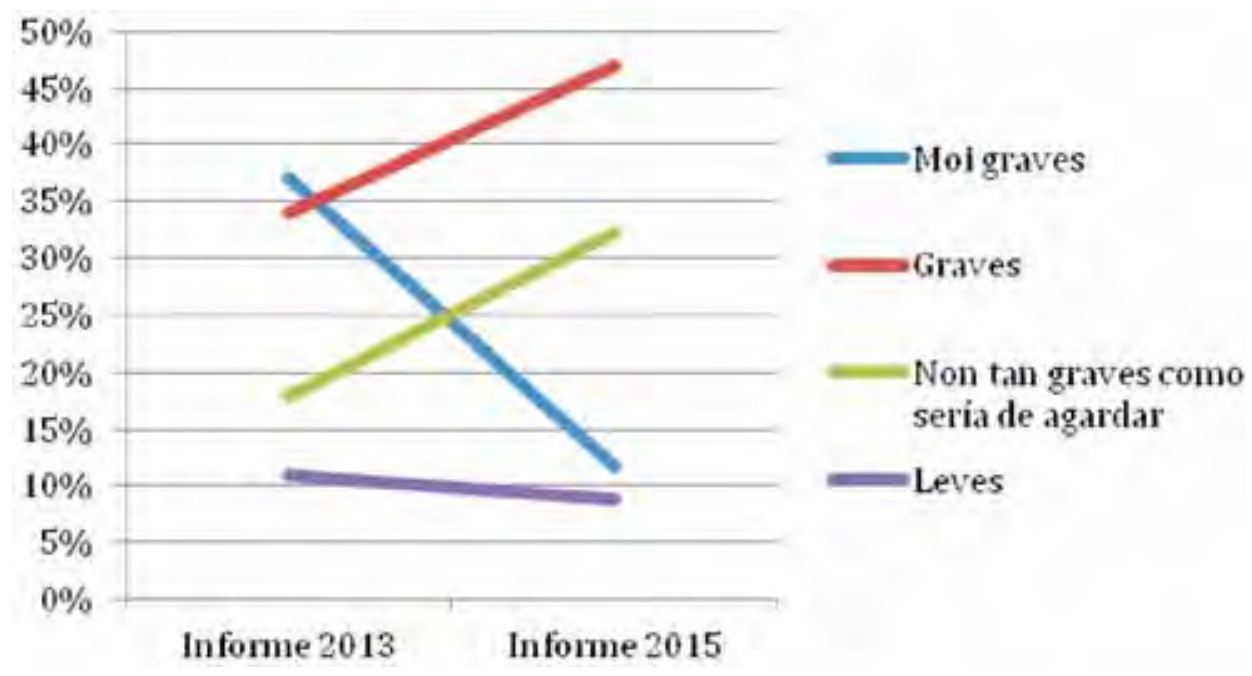

Fonte: elaboración propia.

\subsection{As redes sociais como ferramentas ao servizo da comunicación e as relacións públicas}

As empresas ou institucións que teñen perfil, páxina e conta de usuario nas redes sociais son hoxe unha clara maioría. 0 67,6 \% están presentes, polo menos, nunha destas plataformas. Se non discriminamos por consellarías e consideramos a Xunta de Galicia como unha soa unidade de estudo, igual que facemos cos concellos ou coas deputacións, esta porcentaxe increméntase ata o 85,1\%.

Dentro delas, Twitter é máis empregada (gráfico 4). Teñen conta nesta rede o 61,8 \% das empresas ou institucións (un 91,3\% das entidades galegas que están presentes nas redes están en Twitter); seguida de Facebook, cun $55,7 \%$ (82,6 \% do total con actividade en redes), e de Youtube, cun 26,5\%. Conta tamén cunha certa presenza Instagram, pero non pasa por agora do $8,7 \%$.

Gráfico 4. Presenza das empresas e institucións en redes sociais

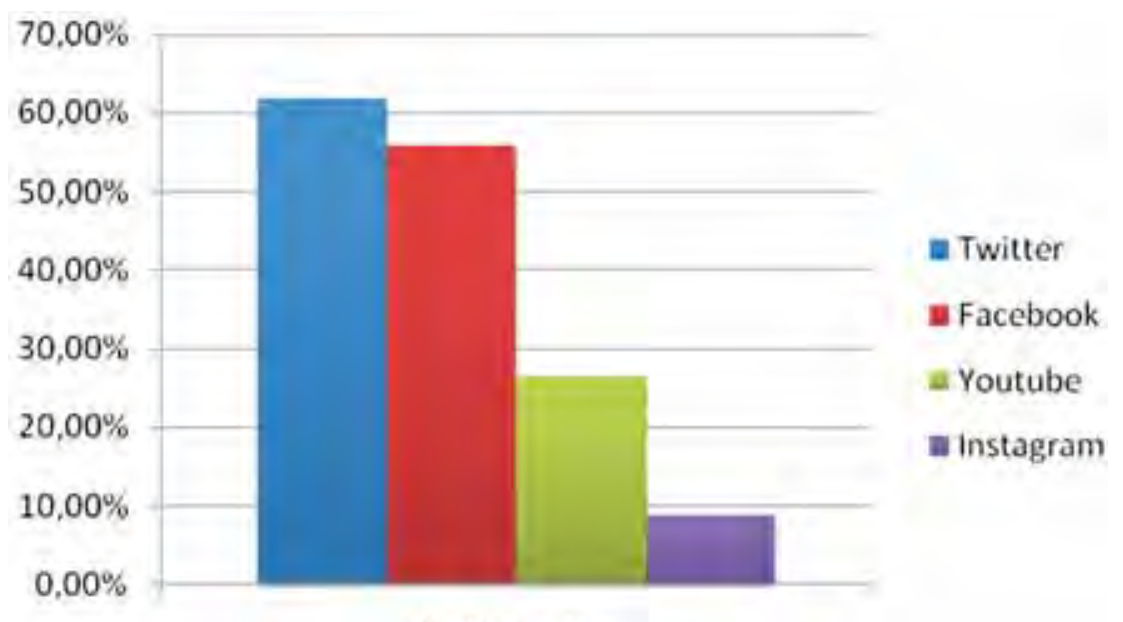

Redes sociais

Fonte: elaboración propia. 
O feito de ser Twitter a rede pola que opta a maioría de empresas e de institucións galegas analizadas, a pesar de ser Facebook a rede social con maior número de usuarios, semella que ten que ver coa importancia cualitativa que se lle dá á primeira como ferramenta de comunicación efectiva cos públicos desas entidades.

En canto á utilidade das redes sociais (gráfico 5), un 55,8 \% dos profesionais considéraas xa unha ferramenta fundamental, o que supón un incremento de case 20 puntos con respecto ao informe de 2013 (Míguez / Rúas 2013: 195); mentres que para un 26,4 \% son unha ferramenta aínda en proceso de introdución e crecemento (un $49 \%$ en 2013). 0 dato das persoas que non percibe a súa importancia mantense invariable no $14 \%$.

Gráfico 5. Evolución na percepción da importancia das redes sociais

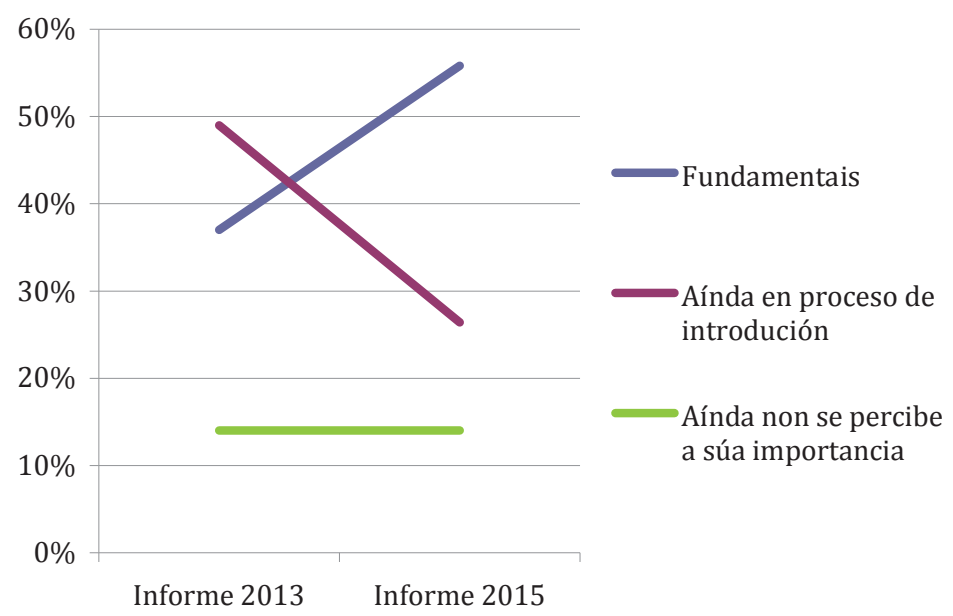

Fonte: elaboración propia.

\section{O GALEGO: USOS E TENDENCIAS NA COMUNICACIÓN INSTITUCIONAL E EMPRESARIAL}

Neste aspecto é no que se observan as maiores diferenzas entre a realidade do ámbito institucional e empresarial. En termos xerais, o 82,3 \% manifesta usar o galego de xeito habitual nas súas comunicacións, fronte a un 17,6 \% que afirma utilizar habitualmente o castelán.

Non obstante, como se apuntaba, para ter un radiografía certa da situación en que se atopa a lingua neste ámbito profesional é imprescindible analizar por separado a realidade nos gabinetes de comunicación das administracións e nos das empresas. No referido ás institucións públicas, o 96,4% usan o galego sempre (75 \%) ou, en todo caso, máis que o castelán $(21,4 \%$ ). Só un concello recoñece usar máis o castelán que o galego e ningunha administración das estudadas emprega o castelán en exclusiva, tal e como ilustra o gráfico 6.

Gráfico 6: Uso do galego nas comunicacións das institucións

Fonte: elaboración propia.

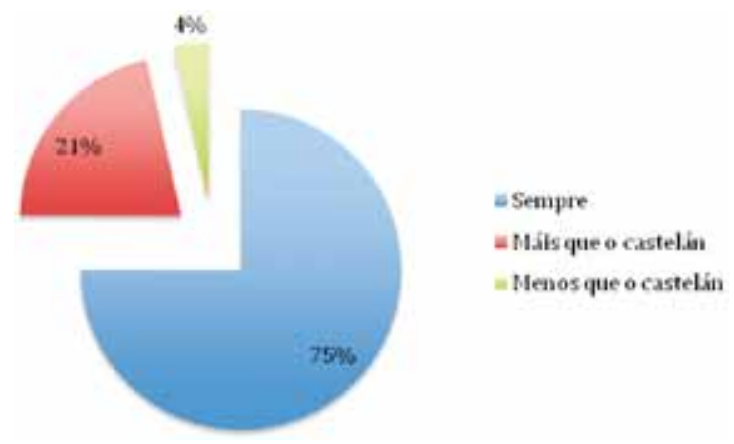


O uso habitual do castelán nas comunicacións, aínda que sexa en menor medida que o galego, obsérvase só no ámbito municipal (independentemente do tamaño e signo político do concello) pero non nas deputacións nin na Xunta de Galicia, que comunican case en exclusiva en galego.

No eido empresarial a realidade é xusto a contraria, practicamente todas as empresas afirman que nas súas comunicacións usan unicamente o castelán. Só unha empresa di que, ás veces, usa o galego, pero sempre menos que a lingua castelá, e outra afirma empregalo sempre.

Do dito ata agora, a situación da lingua na comunicación empresarial e institucional en Galicia non parece ter mudado significativamente no último bienio (2012-2014); de feito, a maioría dos entrevistados (76,4 \%) afirma que no seu ámbito a presenza é a mesma que hai dous anos. 0 uso do galego segue a estar reservado case en exclusiva á comunicación institucional e a súa presenza no ámbito da empresa privada é anecdótica.

En todo caso, de cara á elaboración de futuros informes en que se estude esta evolución, resultaría interesante prestar atención a algúns datos proporcionados pola presente investigación que poderían ser indicios das futuras tendencias. Así, cómpre subliñar que, ademais de existir xa un concello dos das sete principais cidades que recoñece empregar máis o castelán que o galego, hai un 14,2 \% de institucións que, aínda usando o galego sempre, cren que o adecuado sería usar tamén o castelán; algo que apoian, en conxunto, o 32 \% das administracións analizadas, fundamentalmente concellos.

Se tamén neste ámbito a Galicia urbana vai predicindo a mingua no uso do idioma, pódese estar asistindo a un lento, pero progresivo, abandono do galego na comunicación institucional, un terreo que ata agora tiña case en exclusiva.

No lado positivo, é destacable que para un $67,8 \%$ dos responsables de comunicación das institucións o seu uso segue a ser imprescindible. Incluso, no terreo empresarial, a maioría das organizacións que non usan o galego considera que este pode ser unha oportunidade comunicativa.

Gráfico 7. Valoración do uso do galego por parte dos profesionais da comunicación

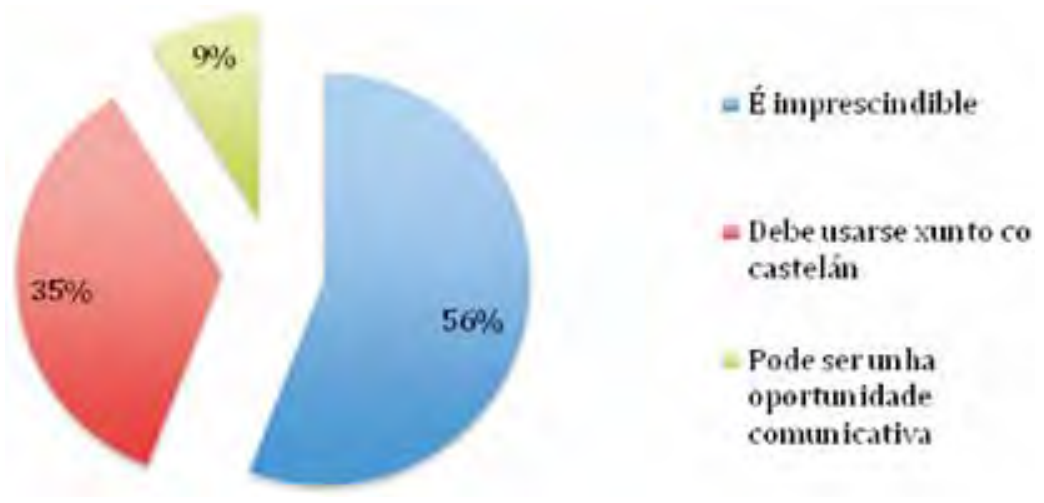

Fonte: elaboración propia.

\section{TENDENCIAS PARA O FUTURO}

Do sinalado polos profesionais da comunicación destacan dous aspectos, a importancia que adquiren, en particular, as redes sociais e, en xeral, a comunicación 2.0, xunto ao crecente protagonismo que moitas das persoas entrevistadas cren que terá a comunicación institucional e empresarial, que gañará peso, impulsada pola mellor formación dos profesionais e a maior sensibilidade dos responsables das entidades cara a ela, o que implicará tamén contratar máis persoal cando a situación económica mellore. 
No lado negativo destacan os efectos que cren que seguirá a ter a crise económica, que se traducirían fundamentalmente en consolidar salarios baixos, afondar na redución do investimento en comunicación e do persoal, e na redución do número de medios de comunicación e, polo tanto, da pluralidade informativa.

\section{CONCLUSIÓNS}

A comunicación institucional debe superar un modelo de comunicación unidireccional e lineal para liderar procesos de relacións públicas con base na conversa (Tarrés 2015), nos que os individuos teñan un papel crecente. Para iso, é necesario crear contidos de calidade. Xa non é suficiente con ter presenza en Internet, é preciso participar na vida da Rede.

A rendición de contas e a transparencia son unha necesidade e unha obriga, non unha opción, se se quere lograr a confianza social. Para acadar este obxectivo precísase unha interacción fluída entre gobernantes e gobernados/as, entre empresas e usuarios/as. O traballo dos relacións públicas a través das redes sociais pode ser unha ferramenta que permita esa comunicación multidireccional.

De feito, o incremento nos dous últimos anos na consideración das redes sociais como ferramentas fundamentais de traballo no eido das relacións públicas é moi destacable. Unha parte importante do novo traballo que están a asumir e asumirán os gabinetes de comunicación pasará por unha correcta xestión e uso delas.

O que a cidadanía esixe é máis transparencia, máis honestidade, máis participación, máis proximidade e máis autenticidade. Algo que neste caso se plasma na necesidade dunha maior regulación, facendo públicos os contratos de publicidade que asinen as administracións públicas ou establecendo criterios obxectivos que regulen esta contratación. A isto engádese a conveniencia de aprobar sen máis demora no Parlamento de Galicia a Lei de publicidade institucional.

Desde o punto de vista da profesión, a pesar dos efectos da crise económica, que segue a golpear o sector e a minguar as posibilidades de crecemento inmediato, a comunicación empresarial e institucional consolídase en Galicia e parece que gañará peso no futuro, impulsada pola maior sensibilización dos responsables das diferentes entidades a respecto das necesidades comunicativas e pola clara falta de persoal nos departamentos de comunicación; ofrecerá, así, novas oportunidades laborais ás persoas formadas en comunicación e relacións públicas. 


\section{REFERENCIAS BIBLIOGRÁFICAS}

ADECEC / DIRCOM (2015): Manual de buenas prácticas en la relación entre los profesionales de la comunicación y los periodistas, Madrid, Dircom.

Fernández-Souto, A. B. / I. Puentes-Rivera (2014): «Relaciones Públicas en la Pequeña y Mediana Empresa de Galicia: El Caso de la Zona Franca de Vigo», en K. Matilla (coord.), Cambio Social y Relaciones Públicas, Barcelona, Editorial UOC, 105-126.

LEI 19/2013, do 9 de decembro, de transparencia, acceso á información pública e bo goberno.

MíGUEz, Ma I. / X. RúAS (2013): «As relacións públicas en Galicia: estado da comunicación empresarial e institucional», en X. López García / M. Rivas Barrós / R. Aneiros Díaz (coords.), A comunicación en Galicia 2013, Santiago de Compostela, Consello da Cultura Galega, 187-201.

Noguero, A. (1995): La función social de las relaciones públicas: historia, teoría y marco legal, Barcelona, EUB.

Solano, L. (1999): Tratado de Relaciones Públicas, Barcelona, Gestión 2000.

TARRÉS, M. (2015): "Comunicación con conciencia para la recuperación de la confianza», en Perspectivas wellcomm de la comunicación 2015. En tiempo de transparencia, ¿competimos o colaboramos en comunicación? Dispoñible en http:/l www.well-comm.es/wellcommunity/perspectivas-2015/ [última consulta: 8 de xuño de 2015].

TORRES y CARRERA (2015): Informe PR. España 2014, Madrid, Grupo PR Noticias. Dispoñible en http://torresycarrera.com/files/ Informes/Informe-PR-Spain-2014.pdf [última consulta: 8 de xuño de 2015]. 
NOVAS EXPERIENCIAS NO CAMPO DA COMUNICACIÓN 



\section{A PERSPECTIVA PROFESIONAL DA FORMACIÓN UNIVERSITARIA EN COMUNICACIÓN: INICIATIVAS DE EMPRENDEMENTO \\ Emma Torres-Romay \\ Universidade de Vigo}

Doi:10.17075/aceg.2016.011 



\section{PRESENTACIÓN}

A comunicación é un sector en que o autoemprego e a organización laboral artellada en estruturas distintas ás convencionais son factores determinantes. A evolución dos medios e do seu consumo así como o desenvolvemento das tecnoloxías vinculadas á comunicación configuraron un novo panorama cambiante e en constante evolución que require de profesionais adaptados e adaptables. Dende as universidades públicas galegas realizouse un enorme esforzo por manter a vinculación permanente co sector profesional, tentando garantir a adecuación da formación ao mercado laboral. Así, os egresados e as egresadas están respondendo a estes cambios con iniciativas de emprendemento e de novo negocio.

Neste traballo recollemos un pequeno achegamento a esta nova realidade que pretende identificar esas novas liñas de desenvolvemento profesional ao tempo que pon en valor as experiencias de titulados do Sistema Universitario de Galicia (SUG).

\section{OBXECTO DE ESTUDO E METODOLOXÍA}

A crise económica coincide no tempo coa modificación dos plans de estudo dos títulos universitarios segundo o RD 1393/2007, do 29 de outubro, polo que se establece a ordenación das ensinanzas universitarias oficiais (máis coñecido como "plan Boloña»). Este cambio tradúcese no conseguinte paso de licenciaturas e diplomaturas a graos. O Real decreto foi aplicado na totalidade dos títulos universitarios de España, que pasaron a ocupar catro anos de formación, ademais de modificar aspectos fundamentais da docencia universitaria como o sistema de avaliación ou o calendario, sendo crucial a aplicación dunha perspectiva de formación en «competencias e habilidades» que implicaban facer o máximo fincapé nunha formación con orientación profesionalizante, tentando romper a vella dicotomía entre «formar persoas vs. formar profesionais técnicos» (Aguilera / Gómez del Castillo 2004).

No caso concreto dos estudos de Comunicación, tamén se procedeu a esa adaptación. O Libro Blanco de los estudios de comunicación, editado pola Agencia Nacional de Evaluación de la Calidad Universitaria (ANECA), serviu como guía para ese proceso, facendo especial fincapé no relativo á inserción laboral dos titulados. Deste xeito, tanto nos estudantes de Licenciatura como nos de Grao, é preciso manter unha observación permanente sobre a adaptación das persoas egresadas ao mercado laboral. Tendo isto en conta, este traballo pretende recoller información ao respecto pero dende unha perspectiva moi concreta, no relativo ás iniciativas de emprendemento e autoemprego.

Dun xeito máis concreto, imos acoutar este traballo no relativo á situación en Galicia. No Sistema Universitario de Galicia están incluídos os tres títulos de Comunicación que serán estudados. Debemos ter en conta que, hoxe en día, tan só saíron ao mercado dúas promocións de graduados, polo que a meirande parte dos datos que se manexan seguen facendo referencia aos estudos de licenciatura. Sexa como sexa, pretendemos proporcionar unha visión da evolución da formación e a inserción laboral dos titulados pero, sobre todo, identificar as tendencias existentes. 
Para poder dar resposta ao noso obxecto de estudo, empregaremos unha metodoloxía sustentada en tres elementos:

- Fontes secundarias. As tres universidades galegas manteñen estudos de seguimento sobre a inserción laboral dos titulados. De igual xeito, outras institucións, como a Xunta de Galicia ou a propia Axencia de Calidade do Sistema Universitario de Galicia (ACSUG), elaboran os correspondentes informes sobre a evolución da colocación. Estes datos proporcionan un punto de partida fundamental para este traballo.

- Fontes primarias. Dun xeito máis concreto, contamos coa información directa dispoñible na Facultade de Ciencias Sociais e da Comunicación da Universidade de $\mathrm{Vigo}^{1}$, onde se conta con indicadores vinculados ao Sistema de Garantía Interna de Calidade (SGIC) e ao Sistema de Información á Dirección (SID).

- Traballo de campo. Consiste no seguimento de experiencias concretas de emprendemento e autoemprego, permitindo identificar as principais características e particularidades daquelas.

\section{ANTECEDENTES}

\subsection{Os estudos de Comunicación en Galicia}

O SUG mantén unha oferta de títulos vinculada ao que tradicionalmente se formulara como «Ciencias da Información»: Grao en Xornalismo (XOR), Grao en Comunicación Audiovisual (CAV) e Grao en Publicidade e Relacións Públicas (PRP). Os tres son herdeiros dos títulos de licenciatura que contaban coa mesma denominación e que naceran no ano 1991 coa implantación da Licenciatura de Xornalismo en Santiago de Compostela (BOE, 10-09-1991), a Licenciatura en Publicidade e Relacións Públicas en Pontevedra en 1993 (BOE, 23-11-1994) e finalmente a Licenciatura en Comunicación compartida entre as tres universidades ( $1^{\circ}$ Ciclo en Vigo e $2^{\circ}$ Ciclo nas tres) no ano 2000 (BOE, 15-01-2004). Nestes 24 anos de historia, o mercado laboral nutriuse dun bo número de titulados (véxase gráfica 1 ).

Os e as egresadas destes tres títulos recibiron unha formación caracterizada pola orientación profesionalizante xa que os plans de estudos de licenciatura antes mencionados facían alusión a esta cuestión contemplando materias con carga práctica e ofrecendo prácticas profesionais recoñecibles por créditos de libre elección. Así, os titulados contaban cun tipo de formación moi próxima ao modelo de grao que posteriormente foi implantado. De feito, o proceso de adaptación foi considerado como relativamente sinxelo non só en Galicia senón tamén nos títulos de Comunicación en xeral. Ese proceso foi motivo dunha rigorosa análise por parte dos investigadores (Rodrigo Alsina 2014).

Resulta interesante ter en conta os datos da ACSUG. Aínda que estes non se atopan desagregados por títulos, os estudos de Comunicación están recollidos na categoría "Ciencias Sociais e Xurídicas IV»². As cifras fálannos dunha percepción medianamente positiva no relativo á adecuación da formación ao mercado laboral e indican que os coñecementos adquiridos foron de utilidade en «algo» (35,25\%), «bastante» $(29,21 \%)$ ou «moito» $(18,17 \%)$ (ACSUG 2014: 132). Os estudos adicionais fan fincapé na importancia que ten a formación práctica para os alumnos e alumnas (Sánchez 2013).

\footnotetext{
${ }^{1}$ Este artigo traballa polo tanto cun nesgo claro ao contar con maior información no relativo aos títulos de PRP e de CAV que se ofertan na Universidade de Vigo. Consideramos porén que isto se complementa na obra completa co traballo de Xosé Manuel Pereiro, decano do Colexio de Xornalistas de Galicia, no relativo á situación profesional do xornalismo.

2 No estudo da ACSUG, Ciencias Sociais e Xurídicas IV inclúe: Diplomaturas en Turismo e en Xestión e Administración Pública, os Graos en Dirección e Xestión Pública, en Turismo e as Licenciaturas en Comunicación Audiovisual, Publicidade e Relacións Públicas e Xornalismo.
} 
Gráfica 1. Titulados en Comunicación en Galicia (1998-2011)

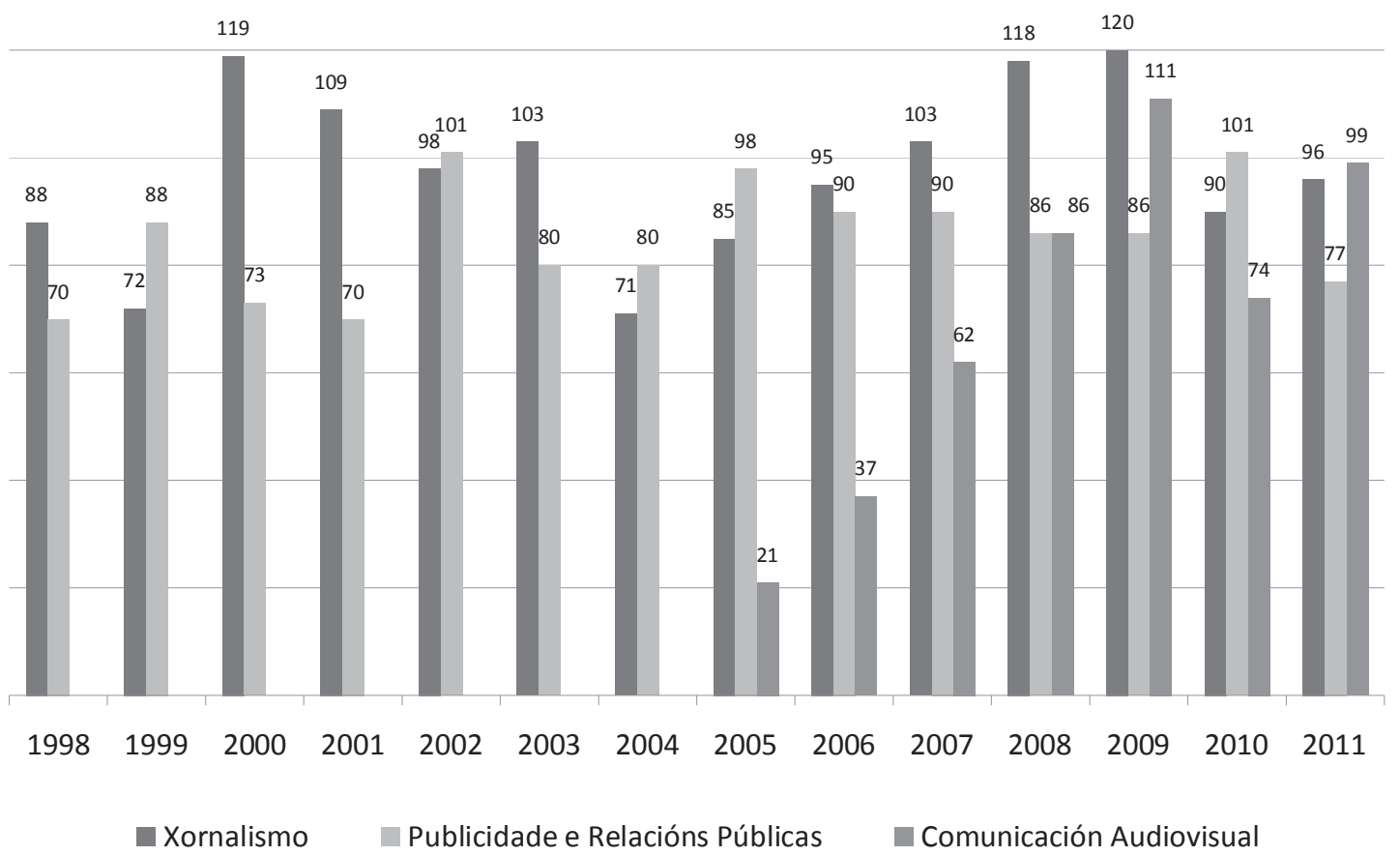

Fonte: INE 2015.

Dun xeito máis concreto e referido á Universidade de Vigo, o Estudo sobre a experiencia académica e profesional das persoas tituladas da Universidade de Vigo recolle datos dos títulos de Publicidade e Relacións Públicas e Comunicación Audiovisual. As e os egresados destes títulos demandan «máis contidos prácticos» (28,6 \% en CAV e 19,2 \% en PRP) e máis «prácticas en empresas» (57,1 \% en CAV e 30,8 \% en PRP). Isto último contrasta co feito de que un $77,8 \%$ dos titulados en CAV e un 75,9 \% no caso de PRP realizaron prácticas profesionais durante a carreira.

\subsection{Os titulados en Comunicación no mercado laboral}

Tendo en conta o relativo á formación profesionalizante dos estudantes, o seguinte dato de interese para configurar os antecedentes do noso obxecto de estudo ten que ver coa súa transición ao mercado laboral. Na gráfica 2 recollemos a situación dos titulados no SUG indicando o que fan ao rematar os seus estudos. Se concretamos estes datos para a rama de Ciencias Sociais e Xurídicas IV atopámonos con que un 50,95 \% dos titulados trabaIla, o 16,13 \% estuda e un 4,27 \% prepara oposicións (ACSUG 2014: 98).

Pero neste punto podemos identificar elementos que condicionan esa adaptación dos titulados ao mercado laboral: o desemprego, o desempeño laboral non vinculado coa formación recibida e a mobilidade xeográfica.

No relativo ao desemprego, os propios egresados e egresadas declaran que as principais causas deste son: 0 «ciclo da economía» (4,35 sobre 5), a «falta de contactos persoais» $(3,79)$, a "pouca experiencia laboral ou profesional previa» $(3,72)$ e as «poucas prácticas realizadas ao longo da carreira» (3,42) (Espada / Martínez 2014: 68). Podemos tomar como referencia o Informe que publica o Observatorio de Ocupaciones do Servicio Público de Empleo Estatal dependente do Ministerio de Empleo y Seguridad Social. No referido ao ano 2014, achega datos 
Gráfica 2. Titulados que preparan oposicións, traballan ou continúan estudos (\%)

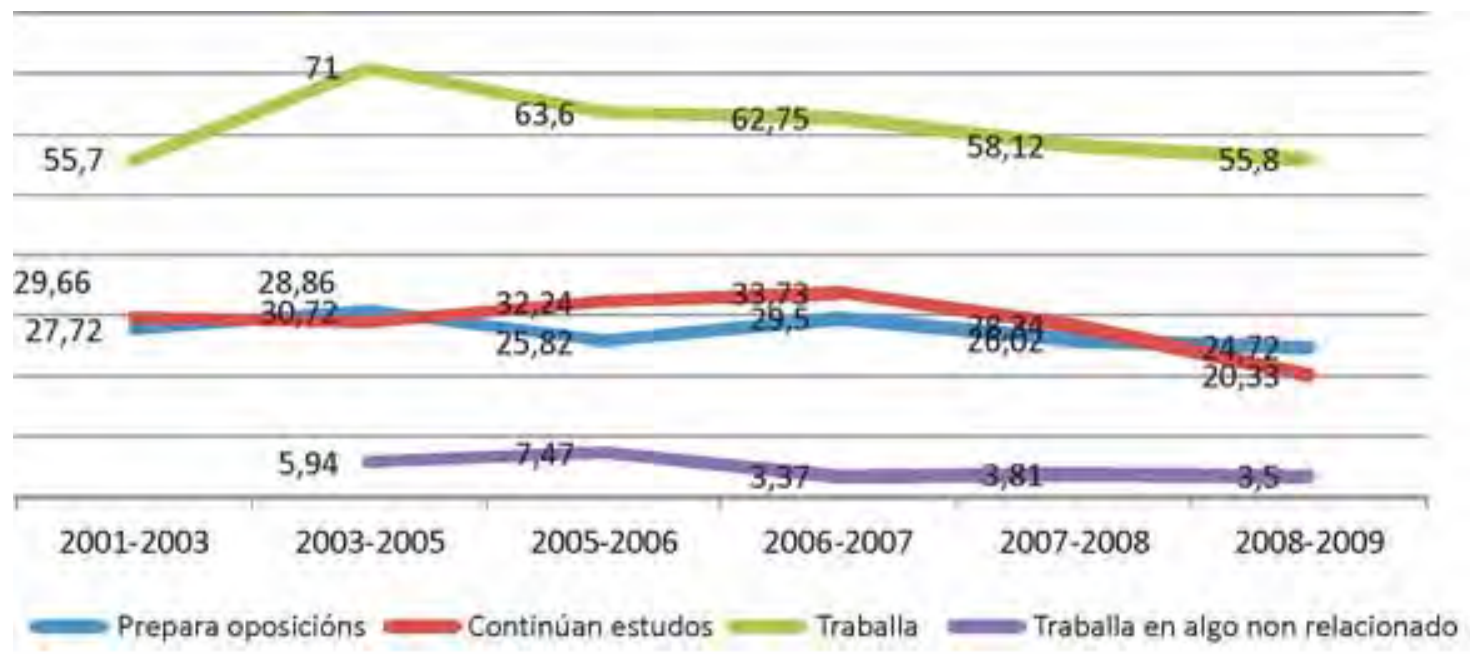

Fonte: ACSUG 2014: 25 e ss.

de ata 135 títulos universitarios dentro da rama das Ciencias Sociais e Xurídicas. Centrándonos nos tres títulos de Comunicación que se imparten en Galicia $^{3}$ atopamos o seguinte:

Táboa 1. Demanda, paro e contratos de titulados en Comunicación (2014)

\begin{tabular}{lrrrrrr} 
& \multicolumn{3}{c}{ Graos } & \multicolumn{3}{c}{ Licenciaturas } \\
\hline & XOR & CAV & PRP & XOR & CAV & PRP \\
\hline Demandantes a fins de 2014 & 301 & 272 & 145 & 9.712 & 4.010 & 4.208 \\
\hline Parados a fins de 2014 & 229 & 192 & 102 & 7.393 & 3.061 & 3.288 \\
\hline Contratos en 2014 & 314 & 399 & 173 & 12.692 & 8.157 & 6.588 \\
\hline Demandantes en 2014 & 279 & 308 & 157 & 10.414 & 6.338 & 5.699 \\
\hline
\end{tabular}

Fonte: Observatorio de Ocupaciones del Servicio Público de Empleo Estatal, 2015.

Como se pode observar, a titulación con maior tradición na educación superior en Comunicación, Xornalismo, é a que achega un maior número de titulados ao mercado laboral. Dentro deste marco xeral e segundo os datos do Consello Social da Universidade de Vigo, os titulados en CAV das promocións de 2008 e 2009 tiñan un 22,2 \% de desempregados e un $13,8 \%$ no caso de PRP, cifras que se sitúan na media nacional, pois o INE indica que 0 desemprego das profesións en xornalismo e comunicación está nun 22,68 \% (INE, 2013). A continuación recollemos datos sobre traballos non relacionados coa formación (táboas 2, 3 e 4).

\footnotetext{
3 Debe terse en conta que a forma nacional de títulos de Comunicación ampliouse notablemente coa implantación dos graos xa que permitiu a creación de novos títulos ou o uso de novas denominacións para estes (por exemplo: Grao en Protocolo, Grao en Comunicación Corporativa, Grao en Medios Audiovisuais, etc.), ademais de recoller os datos das «dobres titulacións» nas que os títulos de Comunicación ofrecen a suma de dúas ramas (por exemplo Grao en Xornalismo e Publicidade) ou, incluso, se vincula con outros estudos (Grao de Publicidade e Marketing ou de Xornalismo e Dereito...). O informe ao que se fai alusión desagrega os datos de cada unha desas denominacións, polo que os cadros achegados se centran só nas denominacións concretas das licenciaturas e dos graos implantados en Galicia.
} 
Táboa 2. Ocupacións máis contratadas titulados en XOR 2014

\begin{tabular}{lrrrr} 
& \multicolumn{2}{c}{ Grao } & \multicolumn{2}{c}{ Licenciatura } \\
\hline Ocupación & Contratos & $\%$ & Contratos & $\%$ \\
\hline Xornalistas & 40 & 12,74 & 2048 & 16,14 \\
\hline Profesionais da publicidade e a comercialización & 10 & 3,18 & -- & -- \\
\hline Locutores de radio e TV e presentadores & -- & -- & 414 & 3,26 \\
\hline Directores de cine, de teatro e afíns & 11 & 3,50 & -- & -- \\
\hline Actores & 11 & 3,50 & -- & -- \\
\hline Monitores act. recreativas e entretenemento & 12 & 3,01 & 282 & 2,22 \\
\hline Técnicos de gravación audiovisual & -- & -- & 386 & 3,04 \\
\hline Empregados administrativos sen atención públ. & 12 & 3,82 & 541 & 4,26 \\
\hline Empregados administrativos con atención públ. & -- & -- & 604 & 4,76 \\
\hline Camareiros asalariados & 23 & 7,32 & 575 & 4,53 \\
\hline Vendedores en tendas e almacéns & 37 & 11,78 & 741 & 5,84 \\
\hline Promotores de vendas & 15 & 3,76 & 291 & 2,29 \\
\hline Azafatos de terra & 14 & 3,51 & -- & -- \\
\hline Electricistas da construción e afíns & 11 & 2,76 & -- & -- \\
\hline Coidadores de nenos en garderías e centros edu. & 9 & 2,87 & -- & -- \\
\hline Peóns de industrias manufactureiras & -- & -- & 327 & 2,58 \\
\hline
\end{tabular}

Táboa 3. Ocupacións máis contratadas titulados en PRP 2014

\begin{tabular}{lrrrr}
\hline & \multicolumn{2}{c}{ Grao } & \multicolumn{2}{c}{ Licenciatura } \\
\hline Ocupación & Contratos & $\%$ & Contratos & $\%$ \\
\hline Deseñadores gráficos e multimedia & 4 & 2,31 & -- & -- \\
\hline Profesionais da publicidade e a comercialización & 19 & 10,98 & 327 & 4,96 \\
\hline Axentes e representantes comerciais & 5 & 2,89 & 213 & 3,23 \\
\hline Monitores act. recreativas e entretenemento & -- & -- & 155 & 2,35 \\
\hline Empregados administrativos sen atención públ & 13 & 7,51 & 405 & 6,15 \\
\hline Empregados administrativos con atención públ & 8 & 4,62 & 158 & 2,40 \\
\hline Camareiros asalariados & 17 & 9,83 & 473 & 4,18 \\
\hline Vendedores en tendas e almacéns & 21 & 12,14 & 558 & 8,47 \\
\hline Promotores de vendas & 17 & 9,83 & 208 & 3,16 \\
\hline Azafatos de terra & 10 & 5,78 & -- & -- \\
\hline Coidadores de nenos garderías centros educativos & 6 & 3,47 & -- & -- \\
\hline Peóns de industrias manufactureiras & -- & -- & 204 & 3,10 \\
\hline
\end{tabular}


Táboa 4. Ocupacións máis contratadas titulados en CAV 2014

\begin{tabular}{|c|c|c|c|c|}
\hline \multirow[b]{2}{*}{ Ocupación } & \multicolumn{2}{|c|}{ Grao } & \multicolumn{2}{|c|}{ Licenciatura } \\
\hline & Contratos & $\%$ & Contratos & $\%$ \\
\hline Xornalistas & 15 & 3,76 & 421 & 5,16 \\
\hline Locutores de radio e TV e presentadores & 11 & 2,76 & 165 & 5,52 \\
\hline Directores de cine, de teatro e afíns & 15 & 3,76 & 450 & 5,52 \\
\hline $\begin{array}{l}\text { Outros técnicos e profesionais de apoio a actividades culturais } \\
\text { e artísticas }\end{array}$ & -- & -- & 274 & 3,36 \\
\hline Monitores act. recreativas e entretenemento & 12 & 3,01 & & \\
\hline Técnicos de gravación audiovisual & 63 & 15,79 & 1.274 & 15,62 \\
\hline Empregados administrativos sen atención públ. & -- & -- & 230 & 2,82 \\
\hline Empregados administrativos con atención públ. & -- & -- & 285 & 3,49 \\
\hline Camareiros asalariados & 30 & 7,52 & 443 & 5,43 \\
\hline Vendedores en tendas e almacéns & 51 & 12,78 & 406 & 4,98 \\
\hline Promotores de vendas & 15 & 3,76 & -- & -- \\
\hline Azafatos de terra & 14 & 3,51 & -- & -- \\
\hline Electricistas da construcción e afíns & 11 & 2,76 & -- & -- \\
\hline Peóns de industrias manufactureiras & -- & - & 424 & 5,20 \\
\hline
\end{tabular}

Fonte: Observatorio de Ocupaciones del Servicio Público de Empleo Estatal, 2015.

En canto á mobilidade xeográfica, os titulados están traballando maioritariamente en Galicia (82,56\%), sendo un 13,87 \% os que traballan noutra comunidade autónoma e un 3,57 \% os que saíron do país: un 2,95 \% con destino a outro país europeo e un $0,63 \%$ a outro continente. Indican como motivos para traballar fóra de Galicia 0 non atopar traballo en Galicia (35,31 \%), unha mellor oferta no exterior (32,31 \%) e razóns persoais (26,07 \%) (ACSUG 2014: 56). Temos que matizar a este respecto que a mobilidade laboral non debería ser entendida en sentido negativo xa que, de feito, as universidades galegas fomentaron a realización de experiencias laborais no exterior ${ }^{4}$. Non obstante, a análise desta mobilidade e das súas consecuencias na perda de talento requirirían dunha valoración específica, máis ampla e profunda.

No caso concreto da Universidade de Vigo, no referido aos estudos de Comunicación, dos titulados nas promocións de 2008 e 2009 (os últimos da licenciatura), un 22,2 \% de CAV e un 29 \% de PRP residían fóra da comunidade. Pero a cuestión fundamental está en que a oferta de traballo para os titulados en Comunicación semella estar fóra de Galicia. A continuación vemos os lugares onde se centraron os contratos dos titulados en Comunicación no ano 2014 (táboa 5).

\section{SITUACIÓN ACTUAL}

Tendo en conta os antecedentes achegados e os perfís formativos que xorden nese contexto (que poden consultarse nas respectivas webs), debemos abordar como se están levando a cabo as posibles iniciativas empresariais, de autoemprego ou de emprendemento por parte dos titulados de Comunicación de Galicia. A Lei orgánica

4 No ano 1993 a Comisión Europea crea o programa Eures, no que colaboran activamente as tres universidades galegas. 
Táboa 5. Provincias con máis contratos de titulados en Comunicación (2014)*

\begin{tabular}{|c|c|c|c|c|c|c|}
\hline & \multicolumn{3}{|c|}{ Graos } & \multicolumn{3}{|c|}{ Licenciaturas } \\
\hline & XOR & CAV & PRP & XOR & CAV & PRP \\
\hline ALACANT & -- & -- & -- & -- & -- & 343 \\
\hline ARABA & -- & -- & -- & 293 & -- & -- \\
\hline BADAXOZ & -- & 14 & 9 & -- & 296 & - \\
\hline BARCELONA & -- & 17 & 10 & 583 & 373 & 275 \\
\hline BIZKAIA & -- & 18 & 6 & 1.600 & 646 & 558 \\
\hline CÁDIZ & -- & -- & 6 & -- & -- & 200 \\
\hline CÁCERES & -- & -- & 6 & -- & -- & - \\
\hline CASTELLÓN & 9 & -- & -- & -- & -- & - \\
\hline CORUÑA, A & 10 & 14 & -- & 530 & 241 & - \\
\hline GIPUZKOA & -- & 8 & -- & 634 & 248 & - \\
\hline HUESCA & 8 & -- & -- & -- & -- & - \\
\hline MADRID & 103 & 139 & 47 & 3.981 & 3.376 & 1.835 \\
\hline MÁLAGA & -- & -- & 318 & -- & 273 & 239 \\
\hline MURCIA & -- & -- & -- & -- & -- & 256 \\
\hline NAVARRA & 12 & -- & -- & 285 & 147 & - \\
\hline PALMAS, LAS & 13 & -- & -- & -- & -- & - \\
\hline PONTEVEDRA & -- & 9 & -- & -- & -- & 188 \\
\hline SALAMANCA & 12 & 8 & -- & -- & -- & - \\
\hline SANTA CRUZ DE TENERIFE & 24 & -- & -- & -- & & - \\
\hline SEVILLA & -- & -- & 11 & 769 & 382 & 238 \\
\hline ZARAGOZA & 38 & 24 & 9 & -- & & - \\
\hline VALENCIA & 20 & 72 & 10 & 595 & 472 & 327 \\
\hline
\end{tabular}

Fonte: Observatorio de Ocupaciones del Servicio Público de Empleo Estatal, 2015.

*As dez provincias con maior número de contratos.

4/2007, do 12 de abril, de universidades, recoñece explicitamente a importancia da universidade non só como institución produtora de programa de investigación e formadora de profesionais de alta cualificación, senón tamén como entidade xeradora e facilitadora de experiencias empresariais nacidas no seo da comunidade docente e estudantil. Porén, a realidade abordada ata o de agora deixa entrever que a opción de traballar por conta propia segue sendo minoritaria nas universidades galegas. Así se recolle na gráfica 3, onde se confirma que a saída laboral prioritaria para os titulados universitarios é o traballo por conta allea.

O pequeno incremento dos traballadores por conta propia é case testemuñal; de feito, no relativo á Universidade de Vigo, só o 2,7 \% dos titulados teñen un primeiro emprego encadrado dentro do concepto de autoemprego ou autónomo (3,3\% de homes e 2,5\% de mulleres sobre o total da universidade). Non obstante, este dato chega ata un 4,4\% no caso das titulacións do ámbito xurídico-social. 0 rechamante é que esa porcentaxe vai subindo xa que na categoría de «emprego actual» o autoemprego ou autónomo chega ao 9,3 \% dos titulados (Espada / Martínez 2014: 85). 
Gráfica 3. Distribución do tipo de traballo dos titulados universitarios

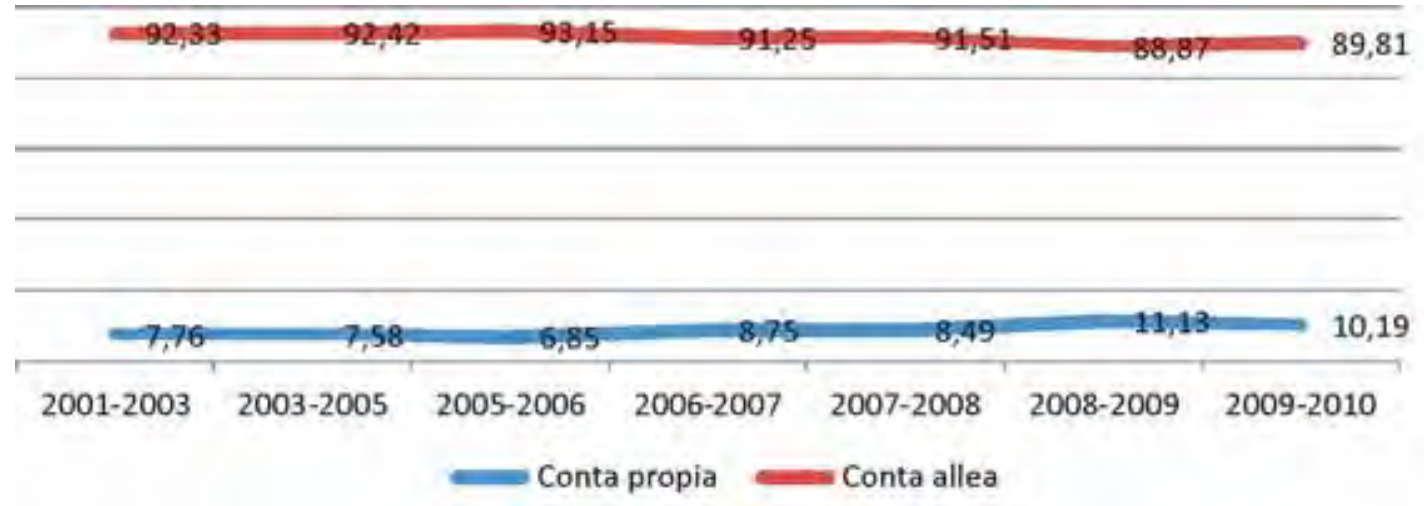

Fonte: ACSUG 2014.

Os datos no relativo ao emprendemento en España non conseguen avanzar. Segundo o Global Entrepreneurship Monitor, o TEA (Total Entrepreneur Activity), que marca o índice de emprendedorismo que mide a taxa de iniciativa de entre 0 e 3,5 anos no mercado sobre unha poboación de 18-64 anos residente en España, situábase en 5,7 no ano 2012 e descendeu ao 5,2 en 2013. Ben é certo que no sector servizos este índice si creceu dende un 25,7 no ano 2012 a un 28,0 en 2013 pero constátase en todos os indicadores que o emprendemento non era un obxectivo prioritario nos traballadores españois. E todo iso a pesar dos esforzos realizados pola Administración pública para dinamizar a creación de empresas 5 .

No referido ao emprendemento en Galicia, contamos con datos incluso inferiores, sendo o índice TEA de 2011 (o último dato dispoñible no GEM) do 4,72, o que supón unha redución respecto ao 5,12 de 2010. Ademais disto, o nivel de formación dos emprendedores constata un paralelismo entre Galicia e España: un aumento de emprendedores con estudos obrigatorios e de formación profesional en detrimento dos universitarios. Non obstante, de xeito particular son máis numerosos os emprendedores potenciais no contorno universitario, ao mesmo tempo que a súa presenza en iniciativas incipientes é similar á que se observa entre emprendedores non universitarios.

Os estudantes universitarios manifestan unha maior propensión a considerar a creación de empresas como oportunidade laboral, aínda que esa proporción non garda correlación cun maior número de iniciativas emprendedoras. Se se observan as características da actividade emprendedora das persoas con estudos universitarios, resulta evidente o predominio das iniciativas individuais e unipersoais, que acaparan practicamente o $80 \%$ dos casos. Ademais, tres de cada catro universitarios que crearon unha empresa manifestan expectativas favorables en relación co incremento do seu cadro de persoal, posicionándoas por riba das perspectivas dos non universitarios. Así mesmo, predominan as iniciativas en sectores de baixo ou nulo contido tecnolóxico (máis do 90 \%), con escasas expectativas de expansión (practicamente o 70 \%) e sen proxección internacional (aproximadamente 0 $85 \%$ ) (CEG 2012: 96).

Ao igual que sucede a nivel nacional e autonómico, as universidades tamén fomentaron o espírito emprendedor mediante diferentes iniciativas e programas. Dende o ano 2011, a Universidade de Vigo convoca os premios INCUVI, un proxecto de pre-incubadora no campus de Vigo que se estendeu ao campus universitario de Pontevedra en 2012 e ao de Ourense en 2015. Pero este é só un exemplo da énfase que as universidades galegas poñen neste tema, precisamente a partir do ano 2011. Nese mesmo ano, a Universidade de Santiago de Compostela

${ }^{5}$ O Ministerio de Empleo y Seguridad Social aprobou en 2013 unha Estrategia de emprendemento y empleo joven 2013/2016. 
crea a Área de Valorización, Transferencia e Emprendemento (AVTE). Xa no ano 2012, o Consello Social da Universidade da Coruña puxo en marcha a Escola de Emprendemento, que buscaba a formación en cultura emprendedora dos titulados universitarios. En todos os casos se manifesta que aínda queda moito que facer no fomento dese espírito emprendedor.

No referido aos estudos de Comunicación, e tal e como apuntabamos no relativo á metodoloxía, tomamos como referencia o caso da Facultade de Ciencias Sociais e da Comunicación da Universidade de Vigo. Neste centro creouse a Rede de antigos alumnos de Publicidade e Relacións Públicas e de Comunicación Audiovisual. Para a dinamización desta cóntase cunha páxina de Facebook, na que participan 552 membros, todos titulados do centro ou docentes, e que serve para o intercambio de información especialmente no referido a ofertas de traballo ou oportunidades laborais. No mes de novembro de 2014, co gallo da celebración do vinte aniversario do centro, elaborouse unha base de datos viva na que os e as egresadas informaban sobre a súa situación laboral. No mes de xaneiro de 2015 esa base contaba con 59 referencias que, a pesar de non ser cuantitativamente representativas, achegan información de grande interese para valorar a evolución do mercado laboral.

A través desta pequena mostra podemos analizar varios factores que nos permiten ter unha visión concreta do que está sucedendo no sector da comunicación, sempre partindo dos condicionantes expostos ata o de agora. Así, dos 59 participantes tan só 7 declararon non ter ocupación, dos cales 5 estaban cursando estudos de Máster. Entre os restantes podemos aplicar a seguinte matriz de valoración:

Gráfica 4. Matriz de valoración da adaptación ao mercado laboral

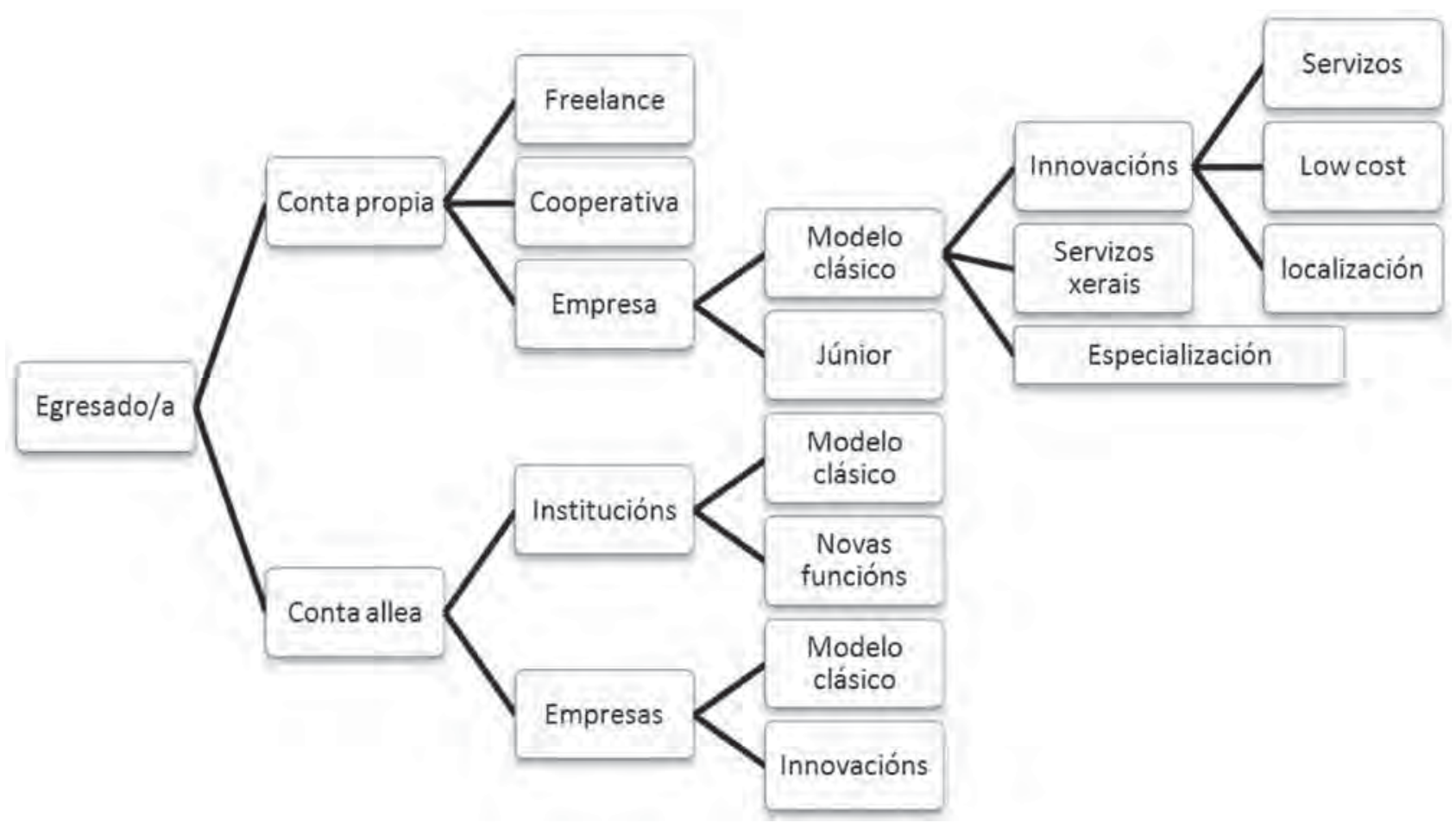

Fonte: elaboración propia.

Desta forma, o primeiro paso está en dividir as persoas egresadas que decidiron emprender actividades laborais por conta propia das que o fixeron por conta allea. Neste sentido, ao igual que a tendencia xeral, os primeiros son minoritarios. Porén e tal e como observamos na matriz, as posibilidades para ese emprendemento semellan terse 
diversificado. Así, atopámonos coa tradicional figura do freelance, moi vinculada co desenvolvemento de traballos de creatividade e publicitarios, pero tamén con cooperativas de comunicación sen deixar de lado os formatos tradicionais de empresas de diversa configuración.

Do total de egresados e egresadas que participaron na base de datos, 10 decláranse freelance, entendendo este como un traballador autónomo ou por conta propia que realiza a súa actividade para terceiros coa peculiaridade de que o seu traballo é retribuído non en función do tempo empregado, senón do resultado obtido. Segundo todas as referencias, este modelo laboral está directamente vinculado co mundo das tecnoloxías da información e da comunicación, onde ten o seu maior predicamento. Os freelance ofrecen servizos de carácter individual, se ben algún deles configurou unha oferta «corporativa» (PuntoCom Comunicación) ou, incluso, traballan neste réxime vinculados a empresas concretas (Logaidea Comunicación).

Aínda que minoritaria, tamén é rechamante a experiencia cooperativa de Ganapan, situada en Moaña e que ofrecía servizos de "comunicación online e offline, publicidade e estratexias de marketing, así como expertos en asesoramento legal e comercial para PEMES e xeradores de contidos e campañas de éxito» (web de Ganapan). 0 traballo estaba liderado por egresados e egresadas de PRP e CAV e a través desa empresa ofertaban outros servizos mediante "profesionais independentes». Esta experiencia conta coa particularidade de elixir unha configuración empresarial que non resulta moi habitual en empresas de comunicación, se ben todo apunta que os espazos de coworking que empezaron a agromar en Galicia incardinan moi adecuadamente este modelo. Verbo disto, debemos incidir que en todos os espazos deste tipo das principais cidades xurdiron experiencias vinculadas coa comunicación e na meirande parte dos casos, con egresados e egresadas dos títulos das universidades galegas.

No relativo á creación de empresas, temos que realizar diversos matices; deste xeito, as empresas clásicas neste sector e vinculadas coas titulacións analizadas serían axencias de publicidade ou de relacións públicas ou produtoras audiovisuais. Neste punto contamos con experiencias de notable éxito como Ekinocio Comunicación, Sra. Nona ou Trisquelia. Nestes casos estamos falando de empresas de comunicación de modelo clásico que ademais derivaron cara a un tipo de axencia de servizos xerais. Con todo, non se atopan exemplos deste tipo no ámbito da Comunicación Audiovisual. No relativo aos e ás egresadas de Comunicación Audiovisual, debemos ter en conta que a posta en marcha dunha produtora require dun equipamento técnico de elevado custo polo que son máis habituais propostas que camiñan na vía da especialización ofrecendo unha parte do proceso (por exemplo, vídeo profesional como fai Hipotálamo Films). É neste punto onde deberían valorarse as innovacións e a este respecto detectáronse varias tendencias de interese.

Ademais das innovacións vinculadas coa oferta dos novos servizos, case sempre vinculados coas redes sociais e a súa xestión (A6pasos ofrece servizos de SEM e SEO relacionados coa organización de eventos), algunhas iniciativas teñen que ver co que podemos denominar emprendemento low cost e que, segundo a información recollida, ten máis relación coa formación en Xornalismo que coa relativa a Publicidade e Relacións Públicas ou Comunicación Audiovisual. Desta maneira, as novas tecnoloxías e a súa xeneralización permitiron que se poidan crear medios de comunicación online sustentados na accesibilidade da tecnoloxía (como é o caso dos blogs) e na especificidade de contidos. Neste punto podemos mencionar a interesante experiencia como fotógrafo de rock de Aítor Costas. E, finalmente, tamén se atopa unha liña de innovación no relativo á localización xa que esta supón o aproveitamento das oportunidades que podería ter a situación de empresas de comunicación (especialmente empresas de deseño gráfico ou vinculadas coas novas tecnoloxías) fóra das grandes cidades galegas. Así, podemos mencionar o traballo de Monster Studio na Estrada ou de Mk Emoción, organización de eventos, no Grove.

O apoio da universidade cara ás experiencias de emprendemento deu lugar a dúas júnior empresas, como son Audiobeesual e Freshysweet. A primeira é unha produtora audiovisual que conseguiu comezar a súa andaina tras obter o premio INCUVI no ano 2011. Composta inicialmente por estudantes de Comunicación Audiovisual, tras os primeiros anos de funcionamento na incubadora de empresas, continúa a súa andaina moi vinculada coa universidade e con propostas de audiovisual para a "divulgación científica». Especialmente interesante foi a 
iniciativa da webserie Fame, nominada aos Premios Mestre Mateo. Ademais desta experiencia no relativo á Comunicación Audiovisual, os estudantes de Publicidade e Relacións Públicas contan cunha axencia de publicidade júnior dende o ano 2014. Freshysweet atópase situada na Facultade de Ciencias Sociais e da Comunicación e renova o seu equipo cada curso académico, contando xa cunha terceira xeración.

Pero neste punto tampouco podemos pasar por alto algo que vai máis aló do noso obxecto de estudo inicial e que se refire ao traballo por conta allea. $\mathrm{Na}$ análise realizada incidimos no feito de que os estudos de Comunicación en Galicia non realizan unha formación especificamente orientada ao emprendemento e que porén traballan nuns perfís moi vinculados co traballo en empresas e institucións. Verbo disto, na seguinte táboa recollemos as denominacións dos postos de traballo que os egresados e egresadas de PRP e CAV ocupan en institucións ou empresas coa finalidade de valorar se os perfís tradicionais seguen presentes no mercado laboral galego ou se se incorporou algunha outra figura vinculada cos cambios nos medios ou nos procesos de comunicación. Así, diferenciamos entre as e os egresados que traballan en empresas de todo tipo daquelas e daqueles que o fan en empresas de comunicación, ao mesmo tempo que facemos unha distinción entre institucións de carácter público ou de carácter privado, entendendo que as necesidades comunicativas poden resultar diferentes:

Táboa 6. Perfís laborais dos egresados en comunicación (2015)

Tipoloxía

EMPRESAS

EMPRESAS DE COMUNICACIÓN
Denominación / descrición do posto

\begin{tabular}{l}
\hline Dirección de Proxectos \\
\hline Dirección de arte/ Produción \\
\hline Departamento de Comunicación e Marketing \\
\hline Comunicación online e offline \\
\hline Xestión comercial e marketing \\
\hline Dpto. comunicación: Social Media, Fotografía e Vídeo promocional \\
\hline Comunicación corporativa e community manager \\
\hline Head of Content Production and Distribution \\
\hline Executivo/a de Contas / Planificación Estratéxica \\
\hline Marketing e redactor/a publicitaria \\
\hline Xefe/a de comunicación institucional \\
\hline Project Management (Digital Services) \\
\hline Departamento de comunicación (Principalmente gráfica e dixital) \\
\hline Edición / posprodución / composición / vfx \\
\hline Director/a de Arte Junior \\
\hline Deseño gráfico \\
\hline Responsable de contas \\
\hline Redactor/a \\
\hline Consultoría de Comunicación \\
\hline CEO Empresa de planificación integral de eventos \\
\hline Business Development \\
\hline Produción e dirección / Comunicación \\
\hline Redactor/a de contidos web \\
\hline Docencia e Investigación Deseño Gráfico \\
\hline Departamento de Comunicación e Marketing \\
\hline Social Media e Deseño gráfico \\
\hline
\end{tabular}




\begin{tabular}{ll} 
Tipoloxía & Denominación / descrición do posto \\
\hline & Director/a de comunicación \\
\cline { 2 - 2 } INSTITUCIÓNS PRIVADAS & Departamento publicidade e marca \\
\hline & Responsable de comunicación \\
\hline & Comunicación \\
\hline
\end{tabular}

Fonte: elaboración propia.

\section{TENDENCIAS DE EMPRENDEMENTO NO SECTOR DA COMUNICACIÓN}

A pesar dos reducidos índices de emprendemento, a tendencia semella marcar á alza nos próximos anos. A vinculación dos títulos de Comunicación coas novas tecnoloxías permite que o acceso ao autoemprego sexa máis sinxelo que noutros sectores. Baixo esta premisa é necesario detectar cales son as tendencias que marcarán o desenvolvemento deste tipo de experiencias nos vindeiros anos:

1. DESLOCALIZACIÓN: as necesidades de infraestrutura empresarial para os traballos do sector da comunicación son cada vez máis reducidas, o que posibilita o aproveitamento das posibilidades de localización fóra dos grandes eixes empresariais.

2. NICHOS DE ESPECIALIZACIÓN: os modelos de servizos xerais seguen a ter demanda se ben non permiten a ampliación ou proxección do negocio. A busca de servizos específicos ou especializados permite o funcionamento vinculado a grandes empresas que subcontratan esas fases ou procesos do produto final.

3. DIVERSIDADE DE MODELOS DE NEGOCIO: o emprendemento en comunicación deberá valerse das posibilidades estruturais que existen no mercado para podendo superar o tradicional formato de freelances e acollerse a outras formas vinculadas co cooperativismo e coa colaboración.

4. PROFESIONAIS-TIPO: dende o punto de vista formativo, a necesaria creación do que podemos denominar profesionais-tipo implica o establecemento dunha serie de perfís profesionais que garantan a calidade necesaria para facer fronte ás dinámicas convencionais do traballo en comunicación.

5. ADAPTABILIDADE: os profesionais-tipo antes descritos deben engadir un factor de adaptabilidade que supón a adecuación desa formación a calquera contexto e a súa posible evolución. Deste xeito, configúrase un perfil de formación en competencias xerais co desenvolvemento de habilidades adaptadas.

6. FORMACIÓN EN EMPRENDEMENTO: as iniciativas de extensión universitaria recollidas nas universidades galegas deberían ser integradas na formación académica regulada dun xeito transversal de maneira que se introduza esa premisa na formación das distintas materias.

7. ESPÍRITO COLABORATIVO: unha das claves existentes no desenvolvemento das experiencias de emprendemento ten que ver coa capacidade de colaboración ou conformación de equipos. Como indicamos, é necesario que no eido da comunicación se avance máis aló dos modelos unipersoais ou freelance xa que a adaptabilidade e especialización mencionadas requiren de equipos de persoas que configuren unha oferta competitiva.

8. CREACIÓN DE REDES: vinculado co anterior, a actual dinámica de funcionamento das empresas de comunicación nos diversos eidos ten máis que ver con produtoras ou xestoras de produtos comunicativos que requiren os servizos de profesionais adaptados ou especializados a cada unha das necesidades que xurdan en cada momento. Desta maneira, a creación de redes profesionais -que poden partir dos centros universitarios- pode resultar fundamental para dinamizar o mercado de profesionais e polo tanto, conseguir unha mellora desas dinámicas de emprendemento. 
9. EFICACIA: por último, non debemos perder de vista que a esixencia de eficacia na formulación dos procesos debe ser o eixe que condicione calquera iniciativa de emprendemento. Isto supón que debe competirse directamente cos servizos que presten as grandes compañías e esa competencia só é posible en termos de eficacia. Eficacia só obtida mediante a aplicación de criterios de proximidade (deslocalización), especialización, profesionalidade e adaptabilidade.

\section{CONCLUSIÓNS}

No presente traballo tentouse analizar o emprendemento dende o punto de vista do proceso que pode (ou non) levar a el. Deste xeito, debemos partir da valoración da formación proporcionada ao estudantado universitario, de tal xeito que entendemos que o primeiro factor está en saber se se lle están dando competencias adecuadas para abordar esa posible saída laboral.

Dende este punto de vista, o número de titulados en Comunicación de Galicia é amplo. Debe valorarse se a oferta se está axeitando ás necesidades do mercado dende o punto de vista cuantitativo e cualitativo. Cualitativamente os títulos ofertados axústanse adecuadamente aos requisitos das titulacións de Grao, proporcionando unha carga práctica adecuada e contando cun deseño de perfís que, como puidemos comprobar, se axusta ás demandas das empresas de comunicación. Porén, tamén se constata que segue sen abordarse o emprendemento como forma de participar no mercado laboral.

O propio estudantado é o que demanda unha maior carga práctica, entendendo que esa sería a vía para axustarse ao mercado actual de traballo. Porén, esa cuestión entronca cun debate xa existente: deben os títulos de grao afondar nesa carga práctica ou deben manterse nunha formación máis vinculada coa mellora de competencias críticas e teóricas? Esta última opción supón profundar nas competencias e non nas habilidades, marcando unha diferenciación moito máis visible entre a formación universitaria e a formación profesional.

Máis aló da formación, a incorporación ao mercado laboral é, segundo os propios estudantes, moi complexa no momento actual. Non obstante, estes mesmos egresados e egresadas son os que seguen sen "arriscarse» pola vía do emprendemento. Esta vía é, como se pode interpretar a través dos datos proporcionados neste traballo, especialmente interesante para os titulados en Comunicación, que, polas particularidades dos servizos que poderían prestar, teñen nesta fórmula unha saída factible.

Achegamos, polo tanto, unha serie de tendencias detectadas no relativo a posibles propostas de emprendemento no campo da Comunicación, obtidas a partir da análise do mercado e, sobre todo, das experiencias postas en marcha por egresados e egresadas dos títulos de Publicidade e Relacións Públicas e Comunicación Audiovisual da Facultade de Ciencias Sociais e da Comunicación da Universidade de Vigo.

Sexa como sexa, este traballo non deixa de ser un achegamento inicial a unha cuestión complexa e aínda en evolución (debemos ter en conta que no ámbito universitario deuse un pulo especial a este modelo a partir de 2011) que poderá variar moito nos próximos anos, especialmente no relativo as starups e a propia evolución das novas tecnoloxías e, polo tanto, dos medios de comunicación. 


\section{REFERENCIAS BIBLIOGRÁFICAS}

ACSUG (2014): Estudo da inserción laboral dos titulados no Sistema Universiatrio de Galicia 2009-2010, Santiago de Compostela, Axencia para a Calidade do Sistema Universitario de Galicia (ACSUG).

Aguilera Jiménez, A. / Gómez del CAstillo, M. T. (2004): «Perspectivas de la Universidad española en el Espacio Europeo de Educación Superior», Revista Latina de Comunicación Social, 57, vol. 7 (http://www.ull.es/publicaciones/latina/20041257aguilera.htm)

ANECA (2005): Libro blanco de los Títulos de Grado en Comunicación, Madrid, Agencia Nacional de Evaluación de la Calidad y Acreditación (http://www.aneca.es/var/media/150336/libroblanco_comunicacion_def.pdf) [última consulta: marzo, 2015].

ANECA (2009): Los procesos de inserción laboral de los titulados universitarios en España. Factores de facilitación y obstaculizacion, Madrid, Agencia Nacional de Evaluación de la Calidad y Acreditación (http://www.aneca.es/var/media/308144/ publi_procesosil.pdf) [última consulta: marzo, 2015].

CEG (2012): Global Entrepreneurship Monitor. Informe Ejecutivo Galicia, 2011, Santiago de Compostela, Confederación de Empresarios de Galicia / Instituto Galego de Promoción Económica (IGAPE) / Universidade de Santiago de Compostela (http://www.gemconsortium.org/docs/download/2628) [última consulta: marzo, 2015].

CEOE (2014): El estado de la innovación empresarial en España, 2014, Madrid, Confederación Española de Organizaciones Empresariales (http://www.ceoe.es/resources/image/estado innovacion_empresarial_espa \%C3 \%B1a_2014_1.PDF) [última consulta: marzo, 2015].

Espada Recarey, L. / Martínez Cacharrón, V. M. (2014): Estudio sobre a experiencia académica e profesional das persoas tituladas da Universidade de Vigo, Vigo, Consello Social Universidade de Vigo.

FreIRE SeoAne, María Jesús (dir.) (2011): Informe inserción laboral de graduados da Universidade de A Coruña. Curso 20092010, A Coruña, Observatorio Ocupacional da Universidade da Coruña.

GEM (2014): Global Entrepreneurship Monitor. Informe GEM España 2013, Cantabria, Editorial Universidad de Cantabria (http://www.cise.es/wp-content/uploads/INFORME-GEM-ESPA \%C3 \%91A-20131.pdff) [última consulta: marzo, 2015].

Ministerio de Educación, Cultura y Deporte (2014): Datos básicos del sistema universitario español, Madrid, Ministerio de Educación, Cultura y Deporte (http://www.empleo.gob.es/ficheros/garantiajuvenil/documentos/EEEJ_Documento.pdf) [última consulta: marzo, 2015].

MonsoRIu, L. (2014): «La Xunta revela que la inserción laboral de los titulados gallegos aumenta al 63 \%», La Opinión de $A$ Coruña, 28 de outubro de 2014 (http://mas.laopinioncoruna.es/canales/graficos/688/la-xunta-revela-que-la-inserci \%C3 $\% 83 \% \mathrm{C2} \%$ B3n-laboral-de-los-titulados-gallegos-aumenta-hasta-el-63-porciento.html) [última consulta: marzo, 2015].

MURCIANo, M. (2010): «La transformación de los estudios de comunicación en España: nuevo contexto europeo de los estudios universitarios y enseñanzas favorecen un espacio de cooperación iberoamericana», Diálogos. Revista Académica de la Federación Latinoamericana de la Facultad de Comunicación Social. FELAFACS, 79, 4-14.

OCDE (2014): Panorama de la Educación 2014, Madrid, Organización para la Cooperación al Desarrollo Económico (OCDE).

RodRIGo ALSINA, M. (2014): «La enseñanza en Comunicación y su proceso de adaptación al EEES como objeto de estudio: una visión panorámica», Comunicación y Sociedad, 27(2), 221-239.

Sánchez García, P. (2013): «La adaptación de los planes de estudio de periodismo al EEES. Propuesta metodológica aplicada a la Universidad de Valladolid», Historia y Comunicación Social, vol. 18, nº esp., 87-100.

Servicio Público de Empleo Estatal (2014): Informe Anual del mercado de trabajo de los titulados universitarios, Madrid, Observatorio de Ocupados del Servicio Público de Empleo Estatal, Ministerio de Empleo y Seguridad Social (http://www. mecd.gob.es/dms/mecd/educacion-mecd/areas-educacion/universidades/estadisticas-informes/datos-cifras/DATOS CIFRAS_13_14.pdf) [última consulta: marzo, 2015]. 


\section{NARRATIVAS TRANSMEDIA E LUDIFICACIÓN. NOVAS ESTRATEXIAS PARA AS INDUSTRIAS DA CULTURA \\ Carmen Costa-Sánchez \\ Universidade da Coruña}

Doi:10.17075/aceg.2016.012 



\section{AS INDUSTRIAS CULTURAIS MUDAN DE PEL}

Rematou a etapa da comunicación de masas. A audiencia fragmentou en audiencias, en plural. O consumidor produce contidos. Levamos a conectividade a calquera lugar, en todo momento. Vivimos pendentes do móbil e lemos en e-readers e tabletas. Xa non queremos só escoitar. Gústanos participar. As cousas permanecen, mentres mudan, ao igual que os nosos hábitos de información e comunicación. Neste novo contexto, os medios tradicionais pertencentes ás grandes corporacións conviven cos novos medios (os medios das bases), na que foi bautizada como a cultura da converxencia (Jenkins 2008).

As novas coordenadas das industrias da cultura experimentan un dobre proceso: por unha banda, a intensificación da tendencia cara á concentración empresarial e homoxenización de contidos a nivel transnacional por medio das economías de escala, o que prioriza unha serie de produtos culturais a nivel global (a cultura do best-seller, do blockbuster, etc.), coas consecuencias negativas para a diversidade cultural (Unesco 2005) que de aí derivan; pola outra, os usuarios, grazas ás novas ferramentas tecnolóxicas, multimedia e de comunicación (baixo o paradigma Web 2.0), deixan de ser receptores pasivos para apropiarse das narracións e crear e difundir os seus propios relatos, ademais de integrarse en comunidades culturais, fieis ás narracións coas que se comprometen (engagement).

A pretensión deste texto é a de reflexionar sobre dúas estratexias que poden axudar as industrias da cultura a adaptarse a este novo ecosistema que as rodea: as narrativas transmedia e as estratexias de ludificación dos contidos.

\section{TRANSMEDIA E LUDIFICACIÓN. DOUS VECTORES CONFLUÍNTES}

A narrativa transmedia (transmedia storytelling, expresión acuñada por Henry Jenkins no seu artigo publicado en 2003 na Technology Review, publicación do Massachusetts Institute of Tecnology) está a revolucionar as estratexias de produción cultural a distintos niveis. Aplicada ao contexto dos relatos de ficción, amosou o seu éxito en canto á expansión do universo narrativo, a implicación dos usuarios, a reciclaxe de contidos e a monetización do proxecto (Scolari 2013).

Segundo explica Rodríguez Lastra (2014: 15), «a narrativa transmedia [...] está nun momento de apoxeo. Investigadores, artistas e público participan no desenvolvemento dunha nova realidade artística, creativa e de consumo cultural que avanza e se expande pola sociedade dunha maneira crecente».

As estratexias transmedia pasan por aproveitar o mellor de cada medio nunha estrutura multiplataforma, que expanda a historia en cada un dos diferentes medios, optimizando a linguaxe e as posibilidades de cada un deles. Non é unha mera adaptación do cinema ao libro ou ao videoxogo, senón unha macroestrutura de diferentes contidos e medios, servindo cada un deles como porta de entrada ao relato.

Segundo explica Scolari (2009: 587):

Trátase dunha estrutura narrativa diferente que se expande por medio de diferentes linguaxes (verbal, icónica, etc.) e medios (cinema, cómics, televisión, videoxogos, etc.). Non consiste na adaptación dun medio a outro 
[...] os diferentes medios e linguaxes participan e contribúen á construción do mundo narrativo transmedia. Esta dispersión textual é unha das máis importantes fontes de complexidade na cultura popular contemporánea.

Fronte aos relatos convencionais e monomediáticos, as narrativas transmedia vense singularizadas por unha serie de feitos diferenciais, que afectan tanto a historia (o contido) como o discurso:

1. Os relatos transmedia deben presentar un maior grao de profundidade, de modo que a complexidade da historia e o sofisticado da ambientación sexan tamén máis elevados (Jenkins 2003).

2. A expansión do relato a múltiples soportes implica a creación de contidos específicos para cada un deles, na procura dunha experiencia satisfactoria para o usuario a través de cada medio. Segundo a definición da Producer's Guild of America, un proxecto transmedia debe compoñerse, polo menos, de tres storylines (tres historias, por tanto) pertencentes ao mesmo universo ficcional, que se desenvolverán por medio de diferentes plataformas (cine, televisión, publicacións, banda deseñada, animación, móbiles...).

3. Cada plataforma supón unha porta de entrada ao relato (Dena 2009). Iso implica que os contidos deben estar adaptados a cada canle para ofrecerlles a distintos perfís de usuarios a posibilidade de coñecer o mundo que se lles presenta (por exemplo, os lectores de banda deseñada non teñen por que ser o mesmo target que os dun libro). Rompe así co concepto tradicional de audiencia, ademais de que require unha formulación previa e reflexiva das plataformas que convén empregar.

4. As audiencias ocupan o centro das estratexias transmedia. Os relatos transmedia agardan dos «espectadores» que exploren as súas historias. Como afirma Jenkins (2008), estas narracións implican o deseño e a creación dun universo propio, o que o autor denomina 'a arte de construír mundos'.

Isto, ligado á capacidade expansiva dos diversos media, fai posible que unha soa historia conteña moitos personaxes principais que artellen, pola súa vez, moitas outras historias, creando todo un universo ficcional «aberto para a exploración dos fans, de forma aparentemente inesgotable» (Jenkins 2008: 113-114). Para Pratten (2011), o transmedia é sinónimo dunha necesaria participación da audiencia, de maneira que o compromiso con cada novo medio ou plataforma, é dicir, con cada nova peza do relato, manteña o entendemento e $\mathrm{o}$ afecto das audiencias cara á historia. " $\mathrm{O}$ atractivo destas ficcións transmedia radica no seu convite á inmersión e á interactividade; son construídas, vendidas e usadas polos fans non só como textos para ser lidos, senón como cosmoloxías que invitan a entrar nelas, experimentalas e interactuar imaxinativamente con elas» (Gwenllian-Jones 2002: 83).

Scolari (2013: 27) explícao así: «algúns consumidores mudaron en prosumidores (produtores + consumidores), apropiáronse dos seus personaxes favoritos e expandiron aínda máis os seus mundos narrativos [...]. Ben sexa escribindo unha ficción e colgándoa en Fanfiction, ou gravando una parodia e subíndoa a YouTube, os prosumidores do século XxI son activos militantes das narrativas que os apaixonan».

5. Un dos seus modelos de negocio (ou de financiamento) máis habituais baséase en parte no crowdfunding, modalidade en que a implicación das audiencias dáse a modo de micromecenados que axudan a financiar a produción.

Neste senso, cada participante convértese nun pequeno produtor, o que pola súa vez reforza a súa implicación na historia e o seu seguimento do proxecto en que participa (retroalimentación do fenómeno fan).

Até o de agora, as narrativas transmedia estiveron especialmente ligadas ao produto audiovisual (un filme, unha serie de televisión ou un videoxogo, fundamentalmente), pero na actualidade poden atoparse proxectos musicais ou teatrais transmedia; as marcas tamén se están a interesar polo fenómeno (Costa-Sánchez 2014a) e existen achegamentos dende o ámbito educativo. 
Os proxectos transmedia adoitan ser de dous grandes tipos:

1. Transmedia nativos: aqueles que nacen e son concibidos dende unha perspectiva transmedia dende a súa orixe. Proceden dunha biblia do proxecto onde se conciben os aspectos de guión (historia/s), medios, audiencias (experiencia) e modelo de negocio.

Experimentan un maior risco pola incerteza sobre o seu éxito. Un exemplo sería a produción española 0 Cosmonauta, proxecto transmedia nativo producido por Riot Collective e estreado en España en $2013^{1}$.

2. Transmedia non nativos: aqueles que derivan de narracións mono-mediáticas pero que, debido ao éxito conseguido, se ofertan e promoven novas plataformas que afondan na historia, nos seus personaxes ou no mundo en que se ambientan. Son os proxectos máis habituais xa que contan coa aprobación do público (mesmo con lexións de seguidores), o que a industria aproveita para continuar rendibilizando na aplicación dun modelo long tail (Anderson 2004).

Os exemplos son numerosos: Matrix, Xogo de Tronos, Harry Potter, Crepúsculo... ou a recente estrea de TVE El ministerio del tiempo (2015). Son casos en que o medio principal (literario ou audiovisual) se ve complementado pola Web, o cinema/webseries, xogos online, libros, banda deseñada, xogos de realidade alternativa e unha infinidade de creacións por parte dos fans (para parodialo, para inventarlle un novo final, para mesturar historias, etc.).

A partir deste conxunto de explicacións das características, singularidades e implicacións das narrativas transmedia, poden tirarse as vantaxes e valor engadido que lle poden achegar a calquera proxecto cultural.

En primeiro lugar, a formulación dun rol participativo ao servizo daquelas audiencias que desexen tomalo, de maneira que ben poidan manterse no lugar tradicional do espectador/lector/ouvinte, ben poidan participar de xeito máis ou menos proactivo.

En segundo lugar, a fidelidade que xeran ao proxecto cultural (por iso é un proxecto en expansión), pois favorecen a inmersión, a identificación cos personaxes e a curiosidade polo mundo narrativo.

En terceiro lugar, as sinerxías que lles poden proporcionar ás distintas industrias da cultura, que poden traballar conxuntamente nun equipo multidisplinar ao servizo dun mesmo obxectivo, unindo os esforzos da industria editorial, audiovisual e web, por exemplo.

En cuarto lugar, a posibilidade de rendibilizar o proxecto por medio de diferentes canles e tipos de públicos. Polo xeral, os modelos freemium ofertan diversidade de contidos gratuítos e de pago para responder e adaptarse ás necesidades dos usuarios.

\subsection{0 xogo como estratexia}

En canto á ludificación, as narrativas transmedia adoitan incorporar dinámicas de xogo para promover a participación dos públicos. A ludificación dos contidos promove a implicación, facilitando a xeración de experiencias en positivo para o usuario. Os seus obxectivos pasan por incrementar o compromiso, a fidelización, a diversión, a participación e a aprendizaxe.

Para chegar aos novos públicos, a cultura estase a volver menos expositiva e máis lúdica, nun senso amplo e profundo (Pérez Latorre 2013). O concepto de ludificación xorde como unha necesidade de chegar ao novo receptor de produtos culturais (o denominado prosumidor) empregando as tecnoloxías interactivas e desenvolvendo as dinámicas propias do termo (bidireccionalidade, comunidade, participación).

${ }^{1}$ Para coñecelo en profundidade cómpre acceder ao web: http://es.cosmonautexperience.com. 
Xa que logo, nesta sociedade móbil e en movemento, nunha sociedade de cidadás e cidadáns activos que queren participar e nun contexto dixital e rede no cal as organizacións falan cos seus públicos de igual a igual, a estratexia da ludificación comparece como un camiño de interese para as industrias da cultura.

Esta estratexia do lúdico pretende, como obxectivo principal, xerar compromiso e fidelizar o usuario, achegándolle unha experiencia de gozo positiva coa que asociar a marca ou produto cultural. Os concursos en redes sociais e social media seguen esta tendencia. Buscan a participación, a interactividade, a fidelización e a promoción dun rol activo para usuarios implicados.

Ademais, as estratexias de ludificación están presentes, explícita ou implicitamente, en moitos dos novos formatos de promoción das industrias culturais, por exemplo nas campañas virais deseñadas a partir de «enigmas» que o público debe resolver (Pérez Latorre 2013).

\section{PROXECTOS TRANSMEDIA EN GALICIA}

Diversos estudos analizaron a aplicación de estratexias transmedia, fundamentalmente a series de televisión españolas (Costa-Sánchez / Piñeiro-Otero 2012; Lacalle / Castro / Sánchez 2014; Rodríguez / Ortiz / Sáez 2014; Tur-Viñes / Rodríguez Ferrandiz 2014) ou longametraxes (Costa-Sánchez 2014b e Mancera / Balanza 2011).

Porén, os traballos sobre esta mesma temática, que se aproximen a producións culturais galegas, son escasos na literatura científica ao respecto.

Este traballo non pretende unha recompilación cuantitativa de experiencias desenvolvidas a nivel de Galicia, senón achegar unha revisión de proxectos recentes e abrir as portas a futuras investigacións que pretendan coñecer en profundidade este fenómeno, enmarcado nas industrias culturais galegas.

Con esta finalidade seleccionouse un proxecto televisivo (Matalobos, 2009-2013) e un proxecto editorial (Os Bolechas, 2000-hoxe). Ambos son casos de produtos de éxito que lograron a creación dun universo narrativo complexo e que gozaron da complicidade das audiencias galegas.

\subsection{Matalobos (Voz Audiovisual e TVG, de 2009 a 2013, 5 tempadas)}

Como recolle a ficha da serie no portal culturagalega.org², Matalobos narra a historia dun clan familiar, os Matalobos, asentado na ficticia vila de Sardiñeira, na costa galega, e dedicado, entre outros negocios, ao narcotráfico. Dúas mulleres, unha xuíza que tenta salvar a súa carreira e unha avogada que tenta salvar a súa vida, arrepoñeranse ao clan mafioso.

Matalobos logra, ao longo das distintas tempadas de emisión, altas cotas de audiencia (desbancando as principais series do panorama televisivo español), ademais de recibir diversos galardóns nos Premios Mestre Mateo, así como o premio á mellor ficción europea en 2012 concedido por Circom³ ${ }^{3}$, competindo con preto de 200 producións procedentes de 23 países. Recibe tamén o Premio da Fundación Garda Civil, pola súa fidelidade á hora de narrar o labor da benemérita na loita contra o narcotráfico.

Moi ben acollido polas audiencias ${ }^{4}$ e pola crítica, este proxecto audiovisual pertencente ao xénero thriller-policial ten como plataforma-base a televisión, emitíndose no prime time dos martes na Televisión de Galicia.

2 http://culturagalega.org/avg/produccion.php?Cod_prdccn=10198\&busca=Matalobos.

3 «Matalobos, premio a la mejor ficción de la televisión en Europa», en http://www.clag.es/es/noticias/matalobos-premio-la-mejor-ficcion-de-la-television-en-europa.

4 "Las redes sociales reclaman el regreso de Matalobos a TVG» (http://telesmash.blogspot.com.es/2012/04/las-redes-sociales-reclaman-el-regreso.html). 
A historia principal, xa descrita, recolle as vivencias da familia Matalobos, centrándose especialmente no personaxe principal da saga, Carmelo Matalobos, interpretado por Luis Iglesia. Pero indo máis aló, pode observarse como se empregaron outro tipo de contidos e ferramentas para a expansión da historia (ver táboa 1), a creación de diversas pontes de entrada ao relato e a súa contribución ao fenómeno fan.

Cómpre matizar que os materiais que non inclúen retallos da historia non forman parte do presente compendio, tales como carteis, fondos de pantalla, a web, o blog ou as redes sociais da serie empregadas exclusivamente como ferramenta de difusión e promoción.

Táboa 1. Contido, historia, canles e grao de interacción no universo transmedia de Matalobos

\begin{tabular}{|c|c|c|c|}
\hline Contido & Historia & Plataforma & Grao de interacción ${ }^{5}$ \\
\hline $\begin{array}{l}\text { Serie de televisión } \\
\text { ( } 5 \text { tempadas) }\end{array}$ & $\begin{array}{l}\text { Historia da familia Matalobos e } \\
\text { dos habitantes de Sardiñeira }\end{array}$ & Televisión & Baixo (espectador) \\
\hline 15 zona: Un día de garda & $\begin{array}{l}\text { Xusto antes do capítulo de Matalobos, } \\
\text { emítese } 15 \text { Zona: Un día de garda, } \\
\text { que acompaña cada semana os } \\
\text { distintos efectivos da Garda Civil nunha } \\
\text { xornada de traballo }\end{array}$ & Televisión & Baixo (espectador) \\
\hline Capítulos especiais & $\begin{array}{l}\text { - Sumario Matalobos } \\
\text { - Capítulos extra-Promos, recapitulacións } \\
\text { e adianto de capítulos-Capítulo de } \\
\text { despedida6: Matalobos bota a vista atrás }\end{array}$ & Televisión & Baixo (espectador) \\
\hline Perfil de Carmelo Matalobos & $\begin{array}{l}\text { O personaxe principal da serie fala } \\
\text { cos seguidores }\end{array}$ & Facebook & Medio \\
\hline $\begin{array}{l}\text { Perfil de Carmen Matalobos, } \\
\text { matriarca do clan }\end{array}$ & $\begin{array}{l}\text { Outro dos personaxes principais fala } \\
\text { da serie cos seguidores }\end{array}$ & Facebook & Medio \\
\hline Perfil dos picoletos da & Personaxes da Garda Civil de & Facebook & Medio \\
\hline Sardiñeira & Sardiñeira falan cos seguidores & & \\
\hline $\begin{array}{l}\text { Club de fans de Carmelo } \\
\text { Matalobos }\end{array}$ & $\begin{array}{l}\text { Comunidade de seguidores do } \\
\text { personaxe da serie }\end{array}$ & Facebook & Medio \\
\hline Frases dos personaxes & $\begin{array}{l}\text { Cortes de frases destacadas elixidas } \\
\text { polos fans da serie }\end{array}$ & Youtube $^{7}$ & Medio \\
\hline Final alternativo & $\begin{array}{l}\text { Proposta de final alternativo para } \\
\text { Carmelo Matalobos }\end{array}$ & Youtube & Alto (cocreadores) \\
\hline Resumo de personaxes & $\begin{array}{l}\text { Creacións-resumos dos momentos máis } \\
\text { importantes da vida de diversos personaxes }\end{array}$ & Youtube & Alto (cocreadores) \\
\hline Nova cabeceira da serie & $\begin{array}{l}\text { Proposta de deseño dunha nova } \\
\text { cabeceira para a serie }\end{array}$ & Youtube & Alto (cocreadores) \\
\hline
\end{tabular}

Fonte: elaboración propia.

${ }^{5}$ Orozco e Vasallo (2014) diferencian entre interactividade pasiva, interactividade activa ou interactividade creativa.

${ }^{6}$ Capítulo-homenaxe a todos os personaxes que formaron parte do universo Matalobos.

7 Os materiais en Youtube sobre a serie son numerosos. Fíxose un esforzo de síntese para recoller as principais tendencias. Tamén se atoparon memes de Carmelo Matalobos en Flickr ou Pinterest. 
Matalobos é un proxecto transmedia non nativo, que destaca pola creación de material audiovisual á marxe da propia serie, mediante o que pode captar o interese de novas audiencias (coas promos e adiantos), manter e fidelizar as xa existentes (coas recapitulacións e sumarios, fundamentalmente) e engadirlle complexidade ao universo narrativo de Sardiñeira (os especiais ou a serie Un día de garda). Os perfís en redes sociais de personaxes tan carismáticos como Carmelo Matalobos ou dona Carme promoven e fomentan a interacción cos fans da serie, ademais de ofrecerlles pistas de como se conducirán as tramas e recibir opinións dos principais destinatarios do produto (un aspecto que narrativamente ten moito interese para calquera produto seriado).

O éxito do formato pode verificarse na cantidade de paratextos creados polos fans, que se converten en cocreadores (prosumidores, por tanto), expandindo o universo narrativo co que se comprometen. Así, propoñen finais alternativos ou cabeceiras, seleccionan as frases e as historias dos personaxes ou remesturan as principais tramas da serie.

Podería terse ido aínda un paso máis aló: publicacións dos personaxes da serie (na rede ou en papel), un xogo online onde se puidese elixir o personaxe protagonista, eventos en que participasen os protagonistas, un xogo de realidade alternativa para resolver algún enigma da serie, etc. 0 universo Matalobos tería acadado cotas máis elevadas de participación e complexidade, así como continuaría nutrindo o fenómeno fan.

\subsection{Os Bolechas (Edicións A Nosa Terra e Edicións Bolanda, de 2000 até a actualidade)}

A familia dos Bolechas é ben coñecida para os máis pequenos. Destinada a un público infantil e/ou do primeiro ciclo de primaria, a saga de libros, creación de Pepe Carreiro, leva dende o ano 2000 máis de 500 títulos editados, pero podemos atopar moitas outras plataformas -non só a editorial- que axudan a expandir o universo narrativo deste proxecto: a serie de televisión (emitida na Televisión de Galicia ${ }^{8}$ ), espectáculos, teatro, música, cómics, xogos e unha importante comunidade de fans. A isto habería que engadir un amplo abano de produtos de merchandising (unha liña de xoiaría infantil, crebacabezas, postais, unha mochila, etc.).

Os Bolechas -que ten como protagonistas os irmáns Carlos, as xemelgas Loli e Pili, Braulio, Sonia, o pequeno Tatá, xunto co seu incondicional can, Chispa- constitúen un proxecto transmedia non nativo feito en galego e en Galicia para as e os máis pequenos. Esta iniciativa educativa e lúdica, que acadou un grande éxito, realiza así o seu traslado a moitos outros produtos culturais.

Por medio das aventuras da familia Bolechas, as e os nenos coñecen a xeografía galega ou viven aventuras nas situacións e realidades cotiás: a escola, a casa, o parque, o autobús, a praia... A cantidade de historias, quince anos despois do inicio desta prolífica traxectoria, resulta moi elevada e non é obxecto do presente traballo.

O universo narrativo dos Bolechas (ver táboa 2) componse dunha gran variedade de plataformas e contidos, que ten como fío condutor os sete personaxes desta serie que parte do editorial como plataforma-base, para logo expandirse a outras canles por medio de novos contidos. Cumpre, ademais, coas características definitorias do fenómeno transmedia: non se require o acceso a todos os contidos (e plataformas) para comprender a mensaxe e xerou unha ampla e activa comunidade de fans.

Como acontece noutros casos, a serie dispón tamén de redes sociais (Facebook, Twitter e Youtube), nas que se dan a coñecer as novidades do proxecto e se propoñen concursos, polo que non son empregadas narrativamente, senón de xeito promocional.

80 anuncio do salto á televisión ten lugar en setembro de 2012. 
Táboa 2. Contido, historia, canles e grao de interacción no universo transmedia dos Bolechas

\begin{tabular}{|c|c|c|c|}
\hline Contido & Historia & Plataforma & Grao de interacción \\
\hline Colección de libros & Varias e independentes entre si & Libro & Baixo (lector) \\
\hline Serie para televisión & Varias e independentes entre si & Televisión & Baixo (espectador) \\
\hline \multicolumn{4}{|l|}{$\begin{array}{l}\text { Os Bolechas } \\
\text { (cinco tempadas) }\end{array}$} \\
\hline $\begin{array}{l}\text { Serie de televisión } \\
\text { Os Bolechas } \\
\text { one2three }\end{array}$ & $\begin{array}{l}\text { Diversas historias orientadas á } \\
\text { aprendizaxe de inglés }\end{array}$ & Televisión & Baixo (espectador) \\
\hline $\begin{array}{l}\text { Especiais televisivos } \\
\text { (p.e. Entroido) }\end{array}$ & Varias e independentes entre si & Televisión & Baixo (espectador) \\
\hline $\begin{array}{l}\text { Brincabolechas } \\
\text { (xira de Nadal) }\end{array}$ & Varias e independentes entre si & $\begin{array}{l}\text { Espectáculos } \\
\text { e xiras }\end{array}$ & Medio \\
\hline $\begin{array}{l}\text { 'Os Bolechas na } \\
\text { máquina do tempo' (xira } \\
\text { pola xeografía galega) }\end{array}$ & Varias e independentes entre si & $\begin{array}{l}\text { Espectáculos } \\
\text { e xiras }\end{array}$ & Medio \\
\hline \multicolumn{4}{|l|}{ Os Bolechas fan unha } \\
\hline banda & Varias e independentes entre si & Libro-cd & Baixo (oínte) \\
\hline $\begin{array}{l}\text { Biblioteca Básica } \\
\text { Os Bolechas }\end{array}$ & Varias e independentes entre si & $\begin{array}{l}\text { Libro interactivo } \\
\text { (inclúe códigos QR) }\end{array}$ & Alto \\
\hline Xogos online & Varias e independentes entre si & Web & Alto \\
\hline Club 'Os Bolechas' & Seguir os Bolechas & Web & Alto \\
\hline
\end{tabular}

Fonte: elaboración propia.

O éxito dos personaxes dos Bolechas permitiu a súa adaptación tanto a nivel de contido (inesgotables historias) como de formato (multiplicidade de plataformas). A fidelidade ao seu grupo de protagonistas é a clave de que os distintos tipos de produtos culturais funcionen. A unión dos esforzos de produción dende diversos tipos de industrias da cultura (a editorial, a musical, a televisiva, a de deseño de xogos) resulta nunha experiencia de éxito para todas elas. E non remata aí. O universo dos Bolechas segue medrando.

\section{CONCLUSIÓNS. TENDENCIAS DE FUTURO}

A reconexión entre as industrias da cultura e a cidadanía é unha necesidade de presente e de futuro. As estratexias transmedia representan un camiño, xa testado, para lograr ese obxectivo. Dende Galicia, ao igual que acontece en España, as experiencias de maior éxito son as de proxectos transmedia non nativos, o que visibiliza certa actitude conservadora por parte dos axentes produtores (primeiro compróbase o éxito do produto, logo realízase a aposta transmedia). Porén, algunhas webseries e outros proxectos dixitais iniciaron experiencias máis arriscadas neste eido (Amores prohibidos 2.0 $0^{9}$, http://poetica.gal, http://www.versogramas.com/gl/...), polo que haberá que continuar analizando como deveñen as novas producións culturais en Galicia.

\footnotetext{
9 http://redenasa.tv/es/amores-prohibido/
} 
Nunha sociedade multipantalla, rede e interactiva, a evolución e adaptación das industrias culturais galegas pasa por repensarse e renovarse. A creación de universos ficcionais multimedios pode resultar unha ferramenta cómplice que axude a conciliar intereses, aposte polo emprego do noso idioma e dos nosos valores culturais, rendibilice a dita aposta empresarial e empatice coas audiencias. 


\section{REFERENCIAS BIBLIOGRÁFICAS}

ANDERSON, C. (2004): «The long tail», Wired Magazine, october, 170-177.

Costa-SÁnchez, C. (2014a): "La Narrativa Transmedia como aliada de la Comunicación Corporativa: Estudio del caso \#Dropped by Heineken», Communication \& Society, 27(3), 127-150.

COSTA-SÁnCHEZ, C. (2014b): «Narrativas Transmedia Nativas: Ventajas, elementos de la planificación de un proyecto audiovisual transmedia y estudio de caso», Historia y Comunicación Social, 18, 561-574.

COSTA-SÁnCHez, C. / PiñeIRo-Otero, T. (2012): «Nuevas narrativas audiovisuales: multiplataforma, crossmedia y transmedia. El caso de Águila Roja (RTVE)», Icono 14, 10(2), 102-125.

DENA, C. (2009): Transmedia practice: theorising the practice of expressing a fictional world across distinct media and environments, Tese de doutoramento, Departament of Media and Communications, University of Sydney (http://elmcip.net/critical-writing/transmedia-practice-theorising-practice-expressing-fictional-world-across-distinct).

GWENLLIAN-JONES, S. (2002): «The six lives of cult television characters». Screen, 43(1), 79-90.

JeNkINS, H. (2003): «Transmedia storytelling», Tecnhology Review (http://www.technologyreview.com/Biotech/13 052/?a=f).

Jenkins, H. (2008): Cultura de la convergencia, Barcelona, Paidós.

Lacalle, C. / D. CAstro / M. L. Sánchez (2014): «España: el auge de la ficción ambientada en el pasado» en G. Orozco / M. I. Vassallo (eds.), Anuario OBITEL 2014. Estrategias de producción transmedia en la ficción televisiva, 273-314 (http:// blogdoobitel.files.wordpress.com/2012/09/anuacc81rio-2014-espanhol.pdf).

ManceRA, M. P. S. / M. T. V. BaLAnZA (2011): "Cinéfilos del siglo XXI. De receptores, aficionados y fans... y otros roles en la era de la web 2.0", Icono 14, 10(1), 8-24.

Orozco, G. / M. I. VASSALlo (2014): «Síntesis comparativa de los países Obitel en 2013», en Orozco, G. / M. I. Vassallo (eds.), Anuario OBITEL 2014. Estrategias de producción transmedia en la ficción televisiva, 23-72 (http://blogdoobitel.files.wordpress.com/2012/09/anuacc81rio-2014-espanhol.pdf).

PÉREZ Latorre, O. (2013): «Apuntes sobre la teoría de la diversión», en Carlos A. Scolari (ed.), Homo Videoludens 2.0. De Pacman a la gamification, Collecció Transmedia XXI, Laboratori de Mitjans Interactius, Universitat de Barcelona, Barcelona, 223-252.

PRATTEN, R. (2011): «Getting started in transmedia storytelling» (http://talkingobjects.files.wordpress.com/2012/01/book-byrobert-pratten.pdf, 05-02-2014)

Rodríguez FerRándiz, R. / F. ORTiz Gordo / V. SÁez NúNEEZ (2014): «Transmedia contents created around Spanish television series in 2013: typology, analysis, overview and trends», Communication \& Society, 27(4), 73-94.

Rodríguez LASTRA, A. (2014): La repercusión de la Narrativa Transmedia en la gestión cultural (http://www.slideshare.net/ Rlastra/la-repercusin-de-la-narrativa-transmedia-en-la-gestin-cultural).

SCOLARI, C. A. (2009): «Transmedia Storytelling: Implicit Consumers, Narrative Worlds, and Branding in Contemporary Media Production», International Journal of Communication, 3, 586-606 (www.ijoc.org/ojs/index.php/ijoc/article/download/477/336).

SCoLARI, C. A. (2013): Narrativas transmedia. Cuando todos los medios cuentan, Barcelona, Deusto.

TUR-VIÑES, V. / R. RodríGuez FERRÁndiz (2014): «Transmedialidad, Series de Ficción y Redes Sociales: El Caso de Pulseras Rojas en el Grupo Oficial de Facebook (Antena 3. España, Cuadernos.info, 34, 115-131.

UnESCO (2005): Convención sobre la protección y promoción de la diversidad de las expresiones culturales (http://unesdoc. unesco.org/images/0014/001429/142919s.pdf). 



\section{UNHA APROXIMACIÓN AO ESCENARIO LABORAL DA INDUSTRIA DA MÚSICA EN GALICIA}

Xaime Fandiño Alonso

Zósimo López Pena

Henrique Neira Pereira

Equipo Canal Campus, Grupo de Investigación Estudios Audiovisuais. Facultade de Ciencias da Comunicación, Universidade de Santiago de Compostela

Doi: 10.17075/aceg.2016.013 



\section{A) INTRODUCIÓN}

A industria musical en Galicia, pola súa dimensión, estratexia, elementos identitarios, autoría, emprendemento... precisa de estudos puntuais e de seguimento no tempo que amosen a súa realidade e a súa evolución. Cos datos obtidos e as hipóteses expostas nestes traballos sectoriais, estaremos en condicións de acadar propostas e estratexias fundamentadas para o desenvolvemento óptimo da industria musical da nosa comunidade, así como a súa proxección internacional. Neste caso que nos ocupa, amósase, a modo de avance primixenio, onde está situado e cal é a fragmentación administrativa e comportamento do mercado laboral deste sector e cales son as oportunidades que pode ofrecer.

\section{B) OBXECTO DE ESTUDO E METODOLOXÍA}

Imos examinar por método cuantitativo se o contexto é favorable para que exista un tecido de industria musical en Galicia. Por isto, consultamos bibliografía especializada sobre a realidade da industria musical, webs especializadas e distintas bases de datos.

En canto á análise do mercado laboral, por medio das estatísticas obtidas, intentarase demostrar se existe necesidade de profesionais da industria musical na comunidade autónoma de Galicia. Despois intentarase delimitar cal é a tipoloxía de empregos relacionados con este subsector das industrias culturais. E, finalmente, reflexiónase sobre o estado do emprego, a percepción administrativa dos postos de traballo relacionados coa industria musical e oportunidades de futuro para poder traballar neste eido.

\section{C) CONTEXTO E ANTECEDENTES}

Existen saídas laborais se temos creación, produción, distribución, consumo e exportación de música gravada e en vivo na comunidade; é dicir, se hai oferta e demanda de profesionais e de produtos. A mellor forma de definir este contexto é amosando datos sobre o consumo de música gravada e en vivo.

Segundo o documento 'Encuesta de hábitos y prácticas culturales 2010-2011', promovido polo Ministerio de Educación, Cultura e Deporte (MECD), nos anos 2010 e 2011 o 96,7 \% das persoas consultadas en Galicia dispoñían de equipamento para escoitar música, así que esta mesma porcentaxe ten acceso a música gravada; 0 que se descoñece é se é música galega, galega feita fóra de Galicia, estranxeira, etc.

Os datos máis recentes sobre música gravada -tanto en formato dixital como físico- atopámolos no informe anual de PROMUSICAE ${ }^{1}$, que é de ámbito estatal. No de 2015 danse datos ${ }^{2}$ referidos a 2014: «Los españoles

\footnotetext{
1 PROMUSICAE, Productores de Música de España, agrupa 116 entidades que no seu conxunto representan máis do 90 \% da actividade nacional e internacional do sector español da música gravada.

2 Véxase http://www.promusicae.es/estaticos/view/4-informes-promusicae, consultada o 18 de marzo de 2015.
} 
se gastaron 149,9 millones de euros en comprar música durante los últimos doce meses, una cifra que supera en un 21,2 por ciento los registros del ejercicio 2013. El mercado discográfico español se coloca así en niveles muy parejos a los de 2011».

En canto a datos de consumo de música en vivo en Galicia, existen unha serie de informes elaborados a partir de enquisas oficiais. Segundo a 'Enquisa de condicións de vida das familias', do Instituto Galego de Estatística, realizada no ano 2006, un 14,11\% da poboación galega de 5 ou máis anos asiste cando menos unha vez no ano a algún concerto de música clásica; un 38,05 \% vai cando menos unha vez no ano a un concerto de música moderna, tradicional ou solista, e un 64,99 achégase cando menos unha vez no ano a unha verbena ou a un concerto dunha orquestra.

Datos máis recentes ofréceos a Sociedad General de Autores y Editores (SGAE), que publica anualmente o número de concertos que se realizan en Galicia, así como o número de formacións de música. No caso da música clásica en todo o territorio español, houbo un total de 15017 concertos en 2012 e 14523 concertos en 2013. Estes serían, de maneira resumida, os cadros cos datos sobre música en vivo aplicados a Galicia, os máis recentes son de 2013:

Cadro 1. Música clásica en Galicia 2012-2013

\begin{tabular}{lrr} 
& $\mathbf{2 0 1 2}$ & $\mathbf{2 0 1 3}$ \\
\hline Concertos de música clásica & 1221 & 1172 \\
\hline Espectadores/as de concertos de música clásica & 251485 & 238479 \\
\hline Recadación de concertos de música clásica & 711576 & 682681 \\
\hline
\end{tabular}

Fonte: SGAE.

Cadro 2. Música sinfónica, de bandas e rondallas en Galicia 2013

\begin{tabular}{|c|c|c|c|c|c|c|c|}
\hline \multicolumn{5}{|c|}{ Concertos } & \multicolumn{3}{|c|}{ Espectadores } \\
\hline & Total & De & Gratuítos & Total & De & Gratuítos & Recadación \\
\hline & \multicolumn{3}{|c|}{ pagamento } & \multicolumn{3}{|c|}{ pagamento } & total (en euros) \\
\hline Sinfónica & 102 & 51 & 51 & 55757 & 42064 & 13693 & 415892 \\
\hline Bandas e rondallas & 399 & 20 & 379 & 64747 & 3967 & 60780 & 38521 \\
\hline
\end{tabular}

Fonte: SGAE.

Outro dato importante é o número de formacións musicais. O Instituto Galego de Estatística publica un censo oficial de entidades musicais dedicadas á interpretación, no que se inclúen agrupacións de cámara e líricas, bandas, coros, orquestras de cámara e sinfónicas. O censo está baseado na 'Explotación Estadística de las Bases de Datos de Recursos Musicales y de la Danza', do Ministerio de Educación, Cultura e Deporte. A cifra total de entidades era 409 no ano 2012 e de 411 en 2013. Quedan fóra deste censo as entidades de vida efémera ou non constituídas legalmente como pequenas bandas de rock, grupos de tabernas ou charangas amateurs para 0 Entroido.

No caso da música popular en vivo en Galicia, a SGAE achega datos referentes a número de concertos, espectadores e recadación destes concertos: 
Cadro 3. Música popular en Galicia 2012-2013

\begin{tabular}{lrr} 
& $\mathbf{2 0 1 2}$ & $\mathbf{2 0 1 3}$ \\
\hline Concertos de música popular & 5206 & 4506 \\
\hline Espectadores de concertos de música popular & 1319209 & 1084316 \\
\hline Recadación de concertos de música popular & 6992891 & 5940059 \\
\hline
\end{tabular}

Fonte: SGAE.

Os datos do Instituto Galego de Estatística son nalgúns casos diferentes; por exemplo, na recadación de concertos de música popular en 2013: 5940059 (SGAE) e 5491000 (IGE).

Malia todo, pódese pensar que cos datos ofrecidos podemos confirmar que hai suficiente oferta e demanda de profesionais e de produtos como para que exista unha industria musical.

\section{D) SITUACIÓN. EVOLUCIÓN/RADIOGRAFÍA}

Como se expresou anteriormente, existen datos sobre o consumo de música gravada e en vivo en Galicia, pero nos temas relativos á consideración da música como industria cultural ou industria do entretemento non hai datos tan concretos.

Facendo a reflexión sobre o que é unha industria cultural, podemos asumir que a industria musical segue un proceso de creación, produción, distribución e consumo. Así, poderiamos asignar a cada fase do proceso un tipo de axente que fai que este negocio funcione; o problema, como veremos, está en que non existe un traballo estatístico axeitado, nin ningunha outra iniciativa que permita saber cantas persoas toman parte no conxunto do proceso.

As fontes principais das que poderiamos obter datos son: a Axencia Tributaria, a Seguridade Social, o Instituto Nacional de Estatística, o Instituto Galego de Estatística, o Instituto Galego das Cualificacións, a Sociedad General de Autores y Editores e entidades profesionais de tipo asociativo. Seguindo esta liña de traballo, convén repasar os tipos de datos que se poden obter de cada unha destas entidades e logo analizaremos os empregos da industria musical e da industria auxiliar a partir das informacións que puidemos obter.

\section{Fontes estatísticas para cuantificar os empregos nas industrias musical e auxiliar}

\subsection{A Axencia Tributaria}

Cada persoa e cada entidade no momento de darse de alta no Imposto de Actividades Económicas (IAE) na Axencia Tributaria deben indicar en que sector ou sectores operarán e obteñen, así, un ou varios códigos para efectos estatísticos. 0 primeiro problema con estes datos é que por exemplo unha empresa pode estar dada de alta con varios códigos pero puntualmente operar só nun sector; o segundo é que estes datos estatísticos non se publican sistematicamente con suficiente nivel de desagregación, polo tanto deben solicitarse nas oficinas da Axencia Tributaria, que os concederá ou non. 


\subsection{A Seguridade Social}

Igual que sucede na Axencia Tributaria, cando unha persoa ou entidade se dan de alta obteñen un ou varios códigos estatísticos da Clasificación Nacional de Actividades Económicas (CNAE); se son varios, un deles é o primario -a súa actividade máis importante- e os demais son secundarios. Por exemplo, as estatísticas elabóranse só considerando os CNAE primarios, polo que quedan fóra delas moitos empregos de firmas que organizan concertos pero non como actividade principal. As estatísticas con suficiente nivel de desagregación non se publican sistematicamente, senón que hai que solicitalas a través do Instituto Galego de Estatística, e os datos achéganse por trimestres, de xeito que non se pode observar a evolución do emprego mes a mes.

Existen varios códigos CNAE que se poden asignar a empresas da industria musical, pero os máis axeitados poden resumirse nos que a continuación se presentan:

3220 Fabricación de instrumentos musicais.

4743 Comercio polo miúdo de equipos de audio e vídeo en establecementos especializados.

4763 Comercio polo miúdo de gravacións de música e vídeo en establecementos especializados.

5920 Actividades de gravación de son e edición musical.

7722 Alugueiro de cintas de vídeo e discos.

9001 Artes escénicas.

9002 Actividades auxiliares ás artes escénicas.

9003 Creación artística e literaria.

9004 Xestión de salas de espectáculos.

9329 Outras actividades recreativas e de entretemento.

Como se ve, a maioría destes códigos non son específicos para os empregos relacionados coa industria musical anteriormente mencionados: mentres existe un por exemplo para o cultivo de tabaco (0115), non hai un código para a figura de intérprete musical ou para a produción de eventos; así pois, só algúns destes códigos van ser de utilidade. A seguinte táboa recolle as afiliacións á Seguridade Social en Galicia segundo os códigos CNAE mencionados.

Cadro 4. Evolución trimestral do emprego 2012-2014. Altas na Seguridade Social

\begin{tabular}{lrrrrrrrrrrrr} 
& $31 / 03 / 12$ & $30 / 06 / 12$ & $30 / 09 / 12$ & $31 / 12 / 12$ & $31 / 03 / 13$ & $30 / 06 / 13$ & $30 / 09 / 13$ & $31 / 12 / 13$ & $31 / 03 / 14$ & $30 / 06 / 14$ & $30 / 09 / 14$ & $31 / 12 / 14$ \\
\hline $\begin{array}{l}\text { Réximes } \\
\text { xeral e por } \\
\text { conta allea }\end{array}$ & 2554 & 2702 & 2689 & 2656 & 2420 & 2555 & 2417 & 2631 & 2449 & 2621 & 2366 & 2832 \\
$\begin{array}{l}\text { Réxime de } \\
\text { autónomos }\end{array}$ & 1531 & 1593 & 1599 & 1590 & 1564 & 1619 & 1638 & 1683 & 1640 & 1748 & 1788 & 1820 \\
\hline
\end{tabular}

Fonte: Instituto Galego de Estatística, con datos da Seguridade Social para altas en códigos CNAE primarios 3220, 4743, 4763, 5920, 7722, 9001, 9002, 9003, 9004 e 9329, epígrafes que poden pertencer a actividades laborais ligadas á industria musical en Galicia.

O código CNAE que agrupa un maior número de persoas é o 9329, unha media de 2396 persoas estiveron de alta na Seguridade Social en Galicia no último trimestre de 2014 baixo esa epígrafe. 0 problema é que inclúe actividades moi diversas, que van desde a explotación de salas de baile e discotecas ata a explotación de estacións 
de esquí, locais de máquinas recreativas ou actividades de socorrismo en praias e piscinas. Outra razón máis pola que o sistema de códigos CNAE non resulta axeitado para a nosa análise.

\subsection{O Ministerio de Educación, Cultura e Deporte}

Achega na súa web datos estatísticos sobre obras musicais editadas, salas de concerto, entidades musicais dedicadas á interpretación e, finalmente, concursos, festivais e outras actividades de música. De aquí podemos extraer bastante información acerca de obras producidas e pouca sobre emprego, a excepción do emprego no sector da ensinanza musical.

\subsection{O Instituto Nacional de Estatística}

Ofrece diferentes estatísticas procedentes de institucións coma o Ministerio de Educación, Cultura e Deporte e outras de elaboración propia, pero, así como existen bastantes datos relativos á industria do libro, en cambio hai poucos sobre a música. Polo tanto, pódese extraer pouca información sobre emprego.

\subsection{O Instituto Galego de Estatística}

Achega datos de enquisas propias -coma o consumo de música gravada e en vivo- e información procedente doutras fontes como o Instituto Nacional de Estatística ou a Seguridade Social. Parte da información está dispoñible na web e pódese solicitar nalgúns casos con maior nivel de desagregación, pero non hai estatísticas específicas que nos poidan dar unha visión da realidade da industria musical.

\subsection{O Instituto Galego das Cualificacións}

Depende da Dirección Xeral de Emprego e Formación da Consellería de Traballo e Benestar. Ofrece datos trimestrais do número de contratos xestionados en Galicia polos servizos de emprego de acordo cun sistema de códigos denominado Clasificación Nacional de Ocupacións (CNO). Os códigos CNO son máis axeitados que os CNAE e os IAE para a análise do número das persoas empregadas na industria musical, pois existe unha categoría específica denominada 'Compositores, músicos e cantantes', e os datos trimestrais amosan claramente a estacionalidade, cun elevado número de contratos no verán -xullo, agosto e setembro-, os meses con máis festas. Con todo, estes datos amosan exclusivamente o número de contratos asinados nun período, polo que as persoas con contrato indefinido ou temporal que comezara en períodos anteriores non figurarán para ese tramo.

\subsection{Axencia Galega das Industrias Culturais (AGADIC)}

A AGADIC publica na súa web estudos sobre a situación das industrias culturais en Galicia baseados en estatísticas coma as mencionadas, pois non dispón de estatísticas nin enquisas propias.

\subsection{Consello da Cultura Galega}

A través do seu Observatorio da Cultura Galega, fornece datos orientados, sobre todo, ao consumo de produtos culturais e acerca do conxunto da industria, a partir de diferentes fontes estatísticas. 


\subsection{A Sociedad General de Autores y Editores}

Máis coñecida como SGAE, é unha entidade española de xestión colectiva dedicada á defensa dos dereitos de autor dos seus socios e socias no ámbito da industria musical. De acordo cos datos facilitados pola propia SGAE, o 31 de decembro de 2014 o número de socias e socios autores en Galicia era de 3297; había, ademais, 37 editores e editoras musicais e 190 herdeiros e herdeiras, en total 3524 persoas asociadas. Isto non quere dicir que todas elas creasen ou interpretasen contidos en 2014, pero é unha cifra importante; conforme a revisión do padrón municipal o 1 de xaneiro de 2014, publicada polo INE, Galicia contaba nese momento con 2748695 habitantes, o que significa que un 0,12 \% da poboación galega está asociada á SGAE -un de cada 780 habitantes de Galicia.

\subsection{Entidades profesionais de tipo asociativo}

Posúen datos referidos unicamente a un ámbito moi concreto, e entre elas podemos citar: Músicos ao Vivo, Asociación Galega de Empresas para Eventos (AGASE), Asociación Galega de Empresas Musicais (AGEM), Promusicae, Unión Fonográfica Independiente (UFI), Music Managers Forum Spain (MMF), Asociación de Representantes Técnicos del Espectáculo (ARTE), Asociación de Promotores Musicales (APM), Asociación Estatal de Salas de Música en Directo (ACCES).

\section{Os empregos na industria musical}

Como se indicou, forman a industria musical as empresas e individuos que desenvolven actividades económicas de creación, produción, distribución e venda de música.

\subsection{Creación}

As profesións que atopamos vencelladas a esta primeira fase son:

- Autores/as, compositores/as.

- Músicos/as, executantes.

- Arranxadores/as.

- Fabricantes de instrumentos musicais.

- Profesores/as de disciplinas musicais.

- A\&R (director/a artístico/a dunha discográfica).

Non hai ningunha fonte oficial única que dispoña do dato concreto de cantas persoas traballan nestas profesións en Galicia, polo que para tentar ter unha aproximación temos que consultar varias estatísticas, que aínda así mostrarán un panorama incompleto.

As estatísticas do Instituto Galego das Cualificacións amosan agrupadas as actividades de composición e execución (músicos e cantantes) nun único código, que é o 2932, que mostra a alta temporalidade existente neste subsector da industria musical; como dixemos, a cifra refírese a persoas que asinaron un ou máis contratos no ano de referencia. 
Cadro 5. Número de persoas que asinaron contratos nos servizos de emprego en Galicia co código CNO 2932 'Compositores, músicos e cantantes en Galicia’ 2012-2014

\begin{tabular}{llll} 
& $\mathbf{2 0 1 2}$ & $\mathbf{2 0 1 3}$ & $\mathbf{2 0 1 4}$ \\
\hline Persoas contratadas & 1794 & 2005 & 2128 \\
\hline
\end{tabular}

Fonte: Instituto Galego das Cualificacións.

Como comparación preséntanse as cifras facilitadas por Músicos ao Vivo, unha organización profesional sen ánimo de lucro que ten como primeira finalidade «representar a todas as persoas afiliadas, mediante a intervención nas relacións laborais e a contribución á defensa e á promoción dos intereses profesionais, laborais, económicos, sociais e culturais, tanto individuais como colectivos, que lle son propios» ${ }^{3}$. Esta organización ten 325 membros, músicas e músicos tanto profesionais como amateurs, e 150 destes membros utilizan un réxime de cooperativa que lles facilita a entidade para facturar as súas actuacións; Músicos ao Vivo forma parte da Federación de Músicos Asociados (FEMA), que reúne entidades con obxectivos semellantes de varias comunidades autónomas. A partir dos datos anteriores, vemos que só unha pequena parte das músicas e músicos que traballan no sector están agrupados na plataforma asociativa.

No tocante ás persoas que fabrican instrumentos musicais, esta epígrafe está no grupo C da CNAE -industria manufactureira- co código 3220 «Fabricación de instrumentos musicais». Esta é a cifra do emprego en 2014:

Cadro 6. Cifra media trimestral de afiliacións á Seguridade Social en Galicia

(CNAE 3220) o 31-12-2014

\begin{tabular}{ll} 
Réximes xeral e por conta allea & 21 \\
\hline Réxime de autónomos & 38 \\
\hline
\end{tabular}

Fonte: Instituto Galego de Estatística, con datos da Seguridade Social.

O seguinte dato é o número de persoas que se dedican a ensinar música no ámbito do ensino regrado.

Cadro 7. Centros, profesorado e alumnos matriculados en ensinanzas regradas de música

(Ensinanzas artísticas do réxime especial) en Galicia. Curso 2012-2013

\begin{tabular}{cccccc}
\hline Centros & Profesorado & Elemental & Profesional & Superior & TOTAL \\
\hline 48 & 993 & 4092 & 3445 & 621 & 8158 \\
\hline
\end{tabular}

Fonte: MECD. 'Estadística de las enseñanzas no universitarias'.

\footnotetext{
3 Véxase http://musicosaovivo.com/uploads/files/ESTATUTOS \%20DA \%20ASOCIACI \%C3 \%93N \%20PROF. \%20M \%C3 \%9ASICOS \%20AO \%20VIVO \%20Definitivo \%281 \%29.pdf, consultada o 17 de marzo de 2015.
} 
Cadro 8. Profesorado de ensinanzas non regradas de música e danza en Galicia

(CNO 2323) o 31-12-2014

Persoas contratadas

Fonte: Instituto Galego das Cualificacións.

En canto a empregos de dirección artística en discográficas (artistas e repertorio, A\&R), última información que falta neste grupo, non dispoñemos deste dato.

\subsection{Produción}

As profesións que atopamos nesta segunda fase da industria musical son:

- Mánagers.

- Produtores/as de discos.

- Editores/as.

- Publicistas.

- Directores/as musicais de escena, vídeo.

- Coreógrafos/as.

- Fotógrafos/as.

- Avogados/as.

- Xestores/as de autoría.

Non puidemos atopar ningunha base de datos oficial que permitise saber cantas persoas traballan como mánagers de artistas de música en Galicia. Con todo, como outra iniciativa de velar pola profesionalización dun sector -antes xa se nomeou o caso de Músicos ao Vivo-, en decembro de 2014 creouse o Music Managers Forum Spain (MMF Spain), que é unha asociación sen ánimo de lucro que comprende as persoas físicas ou xurídicas profesionais que representan en réxime de exclusiva como mánagers ou axentes artísticos a cantantes, músicos, instrumentistas, grupos musicais ou grupos músico-vocais. Actualmente son 45 membros en España e 3 membros en Galicia, algo moi pouco representativo no sector.

No ámbito das empresas dedicadas á produción discográfica e tomando como fonte a web Páxinas Galegas, podemos atopar 15 negocios dedicados maiormente á gravación de pezas musicais. Segundo a fonte consultada, esta sería a súa distribución por provincias:

Cadro 9. Estudos de gravación de música en Galicia

\begin{tabular}{lr} 
A Coruña & 4 \\
\hline Lugo & 2 \\
\hline Ourense & 1 \\
\hline Pontevedra & 8 \\
\hline TOTAL & 15 \\
\hline
\end{tabular}

Fonte: Elaboración propia a partir de www.paxinasgalegas.es.

No que se refire a produtores discográficos, o código CNAE que acolle esta profesión é o 5920, «Actividades de gravación de son e edición musical». 
Cadro 10. Cifra media trimestral de afiliacións á Seguridade Social en Galicia en actividades de gravación de son e edición musical en Galicia (CNAE 5920) o 31-12-2014

\begin{tabular}{ll} 
Réximes xeral e por conta allea & 19 \\
\hline Réxime de autónomos & 23 \\
\hline
\end{tabular}

Fonte: Instituto Galego de Estatística, con datos da Seguridade Social.

Neste ámbito empresarial encádrase a Asociación Galega de Empresas para Eventos (AGASE), que na súa web explica a función dos negocios amparados por esta asociación, que son as actividades de deseño, xestión, montaxe e servizos técnicos de equipos de iluminación, son e imaxe; congresos; produción de eventos de carácter cultural e de entretemento; e, en xeral todas aquelas actividades preparatorias, amais de precisas, para a execución de tales eventos. O día 17 de marzo de 2015 son 23 as empresas dentro do directorio desta asociación ${ }^{4}$.

En canto á edición de obras musicais, dispoñemos dos datos estatísticos do MECD referentes a obras inscritas desde Galicia con ISMN, o International Standard Music Number, un sistema internacional que identifica univocamente as publicacións de música escrita, xa sexa para a súa venda, alugueiro, difusión gratuíta ou para efectos de dereitos de autor. Se ben non achega datos de número de persoas que realizan esta actividade, si que nos indica que esta existe.

Cadro 11. Editores con actividade e obras musicais inscritas con ISMN en Galicia 2013-2014

\begin{tabular}{cccc} 
& Editores & \multicolumn{2}{c}{ Obras musicais editadas } \\
\hline 2012 & 2013 & 2012 & 2013 \\
\hline 8 & 5 & 24 & 10 \\
\hline
\end{tabular}

Fonte: Ministerio de Educación, Cultura e Deporte. Instituto Nacional das Artes Escénicas e da Música. Centro de Documentación de Música e Danza. 'Estadística de la Edición Española de Música con ISMN'.

\subsection{Distribución}

- Xornalistas especializados/as.

- Fotógrafos/as especializados/as.

- Axentes/representantes de formacións musicais.

- Publicistas.

- Vendedores/as de soportes gravados ou dixitais.

Polas características destes traballos e a dimensión da industria musical galega, a maior parte destes traballos son desenvolvidos, xeralmente, por persoas que realizan, ademais, outros traballos no eido cultural ou noutros sectores.

\footnotetext{
4 Véxase http://www.agase.es/asociados/GL/2/empresas-asociadas-a-agase, consultada o 17 de marzo de 2015.
} 
Unicamente no caso de axentes/representantes de formacións musicais podemos achegar o número de empresas en Galicia: no ano 2013 contabilizábanse 11 oficinas de contratación de formacións musicais de verbena na comunidade (Fandiño et al. 2013c).

\subsection{Fase: Consumo}

- Promotores/as

- Produtores/as e técnicos/as de música en vivo

- Xerentes de espazos (locais de ensaios, salas de concertos, discotecas...)

- Programadores/as de espazos

- Xornalistas especializados/as

- Fotógrafos/as especializados/as

De acordo coa Asociación Estatal de Salas de Música en Directo (ACCES), son 41 as salas de música en directo que operan en Galicia en 2014, mentres o Instituto Galego de Estatística indica que son 27 as salas de concerto que había en Galicia nos anos 2012 e 2013, o que revela diferentes criterios á hora de considerar a que espazos lles corresponde esta denominación. Unha terceira cifra é 34, concernente ás salas que forman parte do circuíto Rede Galega de Música ao Vivo ${ }^{5}$ da Axencia Galega das Industrias Culturais (AGADIC). En canto a emprego, o Instituto Galego de Estatística, por medio de datos facilitados pola Seguridade Social, ten datos do número de persoas que se dedican á xestión de salas de espectáculos (código CNAE 9004).

Cadro 12. Cifra media trimestral de afiliacións á Seguridade Social en Galicia en actividades dea xestión de salas de espectáculos o 31-12-2014

\begin{tabular}{ll}
\hline Réximes xeral e por conta allea & 26 \\
\hline Réxime de autónomos & 37
\end{tabular}

Fonte: Instituto Galego de Estatística, con datos da Seguridade Social.

\section{A industria auxiliar}

Segundo a resolución do 24 de xuño de 2010, da Dirección Xeral de Relacións Laborais, pola que se dispón a inscrición no rexistro e a publicación no Diario Oficial de Galicia do primeiro convenio colectivo autonómico do sector de eventos, servizos e producións culturais de Galicia ${ }^{6}$, catalóganse os empregos da industria auxiliar de

\section{Grupo I:}

- Director/a creativo/a, escenografía, son, iluminación, informático/a...

- Director/a xeral técnico/a.

- Produtor/a executivo/a.

\section{Grupo II:}

- Enxeñeiros/as técnicos/as.

- Produtor/a de evento.

- Xefes/as de sección.

${ }^{5}$ Fonte: http://www.galescena.info/gfx/Redes/ciclo7/Listaxedeprogramadores2015.pdf, consultada o 4 de marzo de 2015.

${ }^{6}$ Véxase http://www.xunta.es/dog/Publicados/2010/20100728/Anuncio295CA_gl.pdf, consultada o 4 de marzo de 2015. 


\section{Grupo III:}

- Condutor/a profesional.

- Dinamizador/a de actividades.

- Estilista.

- Monitor/a didáctico/a.

- Oficial especialista.

- Rexedor/a.

- Técnico/a ou oficial administrativo/a.

- Técnico/a especialista.

Grupo IV:

- Auxiliar administrativo/a

- Axudante de produción

- Vendedor/a de billetes.

- Monitor/a de tempo libre.

- Monitor/a de talleres.

- Azafata/o de eventos.

\section{Grupo V:}

- Auxiliar de produción.

- Acomodador/a.

- Auxiliar organización.

- Auxiliar montaxe-desmontaxe.

- Carga-descarga.

- Conserxe-porteiro/a.

- Controlador/a de accesos.

- Limpador/a.

- Modelo de posado.

- Mozo/a de almacén.

- Pasador/a de ferro.

- Azafata/o.

- Vixilante de sala.

música en vivo do seguinte xeito:

Outros empregos non reflectidos aquí pero que estarían presentes no ámbito da industria musical son os de persoal profesional da musicoloxía e persoal profesional da investigación en ámbitos musicais.

\section{A verbena, un subsector clave}

Todos os estudos sobre a industria musical en Galicia presentan carencias dalgún tipo pola falta de fontes oficiais axeitadas para realizar unha contabilización completa do emprego no sector. Ante isto, unha opción que supere estas eivas é a da contabilización directa ou, nos casos en que non sexa posible, a estimación do número de profesionais que realizan o seu traballo no conxunto do sector ou nun subsector.

O estudo Do palco ó escenario. Unha aproximación analítica á industria da música nas festas populares de Galicia analizou unha parcela da industria musical en Galicia que é a industria das orquestras de verbenas, que facturaron no ano 2010 unha cifra estimada de 26,2 millóns de euros só en actuacións en verbenas en Galicia -excluídas por tanto as actuacións fóra de Galicia e en salas de festa galegas.

Segundo Fandiño et al. (2013a: 89), no que se refire ao emprego que xera este subsector da industria musical, «estimamos que os profesionais regulados da verbena entre músicos e técnicos, rondan os 3.116». En canto ao número de formacións, apreciábase o seguinte: «Son 624 as formacións -dúos, tríos, grupos, orquestras...- das que constatamos actuacións en Galicia desde xaneiro de 2010 a abril de 2013» (Fandiño et al. 2013c: 3375).

Unha contabilización ampliada ás empresas e profesionais de todo o sector podería, pois, achegar unha imaxe máis precisa da industria musical en Galicia.

\section{E) LINGUA GALEGA}

Non existe un código CNAE específico para editores de obras musicais, pero dispoñemos da Estatística da Edición Española de Música con International Standard Music Number. Os editores con actividade e obras musicais inscritas en ISMN en Galicia en 2012 e 2013 móstranse do seguinte xeito: 
Cadro 13. Obras musicais editadas en galego inscritas no ISMN

\begin{tabular}{lcc}
\hline & 2012 & 2013 \\
\hline Obras musicais editadas en galego inscritas co ISMN & 8 & 6
\end{tabular}

Fonte: Ministerio de Educación, Cultura e Deporte. Instituto Nacional das Artes Escénicas e da Música. Centro de Documentación de Música e Danza. 'Estadística de la Edición Española de Música con ISMN'.

Isto non quere dicir que se compoña tan pouco en Galicia, senón que os temas compostos non necesariamente pasan por esta canle. No caso da SGAE, tampouco existe unha cifra do número de obras creadas en Galicia, xa que estas se poden rexistrar nas oficinas da entidade na comunidade e tamén por Internet, e no caso destas últimas non dispón de datos estatísticos da súa procedencia xeográfica.

\section{F) TENDENCIAS PARA O FUTURO}

Existe un bo número de profesionais da música con gran capacitación, así como unha tradición de centros de formación, pero hai poucas posibilidades de formación superior en Galicia no eido da xestión da industria musical. Neste ámbito obsérvase que poderían existir as seguintes saídas profesionais:

- Responsable de xiras e concertos.

- Road manager.

- Promotor/a-axente de eventos artísticos e musicais.

- Mánager de bandas.

- Produtor/a musical.

- Especialista en A\&R (artistas e repertorio).

- Intérprete.

- Compositor/a de pezas musicais.

- Letrista.

- Xestor/a de salas e institucións dedicadas á música.

- Crítico/a-xornalista especializado en temas da industria musical.

- Editor/a musical.

- Investigador/a-docente no ámbito dos Popular Music Studies.

- Compositor/a de bandas sonoras para videoxogos.

- Directores/as, produtores/as e realizadores/as con especialización en gravación e emisión en directo de concertos vía streaming.

- Profesional do deseño de apps orientadas á música.

Estas actividades e as que sen dúbida irán xurdindo nos vindeiros anos coa evolución da tecnoloxía serán fundamentais para apoiar o proceso de profesionalización da industria musical en Galicia. 


\section{G) CONCLUSIÓNS}

As estatísticas dispoñibles en fontes oficiais ou entidades asociativas do sector da industria musical non permiten na actualidade ofrecer unha imaxe o máis aproximada posible á realidade da facturación e emprego do sector. Con todo, sabemos que a vida de como mínimo catro milleiros de profesionais en Galicia xira arredor da música: 2128 persoas contratadas en 2014 como 'compositores, músicos e cantantes', 993 persoas que exercen tarefas de profesorado en ensinanzas regradas, 678 persoas contratadas para ensinanzas non regradas de música e danza, 63 en xestión de salas de espectáculo, 59 que fabrican instrumentos musicais, 42 persoas en gravación de son e edición musical... e moitas máis que non figuran en estatísticas específicas, así como as persoas que traballan na industria auxiliar.

Hai, ademais, 8158 rapazas e rapaces estudando música de xeito regrado en Galicia: isto supón unha formidable canteira para a industria musical do futuro. Esta cifra amosa, ademais, o enorme interese que produce a interpretación musical nunha parte importante da mocidade galega.

A profesionalización do sector coa implantación das novas profesións con capacidade de xestionar a creatividade e o talento é, cremos, a receita que precisa a industria musical en Galicia para continuar medrando e evolucionando así como para acadar a internacionalización deste sector.

Obsérvase, tamén, que é preciso alentar a investigación sobre a industria musical, para obter datos a partir dos que se poidan realizar análises que axuden a desenvolver estratexias e tomar decisións para a orientación e posicionamento internacional competitivo deste sector, sacando partido dun patrimonio exclusivo tanto lingüístico como musical e con vocación atlántica. 


\section{REFERENCIAS BIBLIOGRÁFICAS}

AA.VV. (2010): As cifras da industria cultural galega. Artes escénicas, Audiovisual, Música e Produto gráfico. Análise cuantitativa, Santiago de Compostela, AGADIC, Axencia Galega das Industrias Culturais. Recuperado de http://www.agadic.info/temas/agadic/gfx/publicacion/as_cifras_da_industria_cultural.pdf [última consulta: 27 de marzo de 2015].

AA.VV. (2011): Estudo das industrias culturais e creativas en Galicia e Norte de Portugal realizado pola agrupación europea de cooperación territorial, Agrupación Europea de Cooperación Territorial Galicia Norte de Portugal. Recuperado de http://www.agadic.info/temas/agadic/gfx/publicacion/Estudo_ICC.pdf [última consulta: 27 de marzo de 2015].

BelHo, V. (coord.) / F. Braña / M. LoRenzo / E. Lozón (2007): A industria musical en Galicia, Madrid, Universidad Complutense de Madrid / ICCMU. Recuperado de http://www.mastergestioncultural.org/files/File/TESINAS/TO70169 \%20Vctor \%20Belho \%20Industria \%20musical \%20en \%20Galicia \%20080922.pdf [última consulta: 24 de marzo de 2015].

Fandiño Alonso, X. (coord.) / M. González / Z. López / H. Neira / J. C. Regueira (2013a): Do palco ó escenario: Unha aproximación á industria da música nas festas populares de Galicia, Santiago de Compostela, Andavira Editora.

Fandiño, X. / C. Regueira / H. NeiRA (2013b): «Informe Orquestras de Galicia 2011/2012 (As verbenas)», en Margarita Ledo Andión / Maria Inmacolata Vassallo de Lopes, Libro de Actas. XIII Congreso Internacional Ibercom, Santiago de Compostela, IBERCOM / AssIBERCOM / AGACOM, 3370-3374.

Fandiño, X. / C. Regueira / Z. LóPez (2013c): «Informe Orquestras de Galicia 2011/2012 (As orquestras)», en Margarita Ledo Andión / Maria Inmacolata Vassallo de Lopes, Libro de Actas. XIII Congreso Internacional Ibercom, Santiago de Compostela, IBERCOM / AssIBERCOM / AGACOM, 3375-3384.

FreIXANes, V. / A. MeIXIDE (eds.) (2010): O capital da cultura: Unha achega ás industrias culturais de Galicia, A Coruña, Centro de Investigación Económica e Financeira (CIEF) / Fundación Caixa Galicia.

Ministerio De Cultura (2011): Presentación. Encuesta de hábitos y prácticas culturales 2010-2011, Madrid, Secretaría General Técnica. Subdirección de General de Publicaciones, Información y Documentación.

\section{RECURSOS CONSULTADOS EN INTERNET}

http://emprego.xunta.es/cnopro

http://musicadanza.es/_es/inicio.html

http://www.agase.es

http://www.ardan.es

http://www.cndm.mcu.es

http://www.ige.es

http://www.ine.es

http://www.paxinasgalegas.es

http://www.promusicae.es

http://www.sgae.es

https://sabi.bvdinfo.com 


\section{A CULTURA EN INTERNET: FACER DA NECESIDADE VIRTUDE Montse Dopico \\ M}

Doi:10.17075/aceg.2016.014 

A presenza da cultura na rede increméntase ao mesmo tempo que descende na prensa tradicional, onde se reforza a xa vella tendencia a desprazala ás paxinas de local ou a fusionar a información cultural coa de sociedade ou coa de lecer. E esta é unha realidade que se enmarca, por unha banda, na crise do modelo de negocio dos medios de comunicación convencionais e, pola outra, e en relación con ela, co desemprego e a crecente precariedade dos e das xornalistas. Mais tamén coa existencia dun nicho de mercado que existe e que a maior parte dos medios non souberon nin, moitas veces, quixeron atender.

A sociedade foi neste, coma en moitos outros contextos, por diante das empresas de comunicación. Profesionais non só do xornalismo senón de diversos ámbitos da cultura ou da educación asumiron boa parte dese traballo ao que os medios renunciaron. E Internet supuxo, nese sentido, a oportunidade para crear e difundir un tipo de información cuxa produción se torna cada vez menos dependente das estruturas da vella prensa. A desaparición de cabeceiras como Vieiros, A Nosa Terra, Xornal de Galicia e Galicia Hoxe, o peche de suplementos culturais como - Luzes da edición galega de El País ou a redución do persoal especializado en cultura, nos poucos lugares en que existía -caso, por exemplo, de La Voz de Galicia-, contraeran máis aínda a xa relativamente escasa atención prestada á cultura polos medios do país.

O libro centra os contidos da maior parte desa rede de blogs e/ou medios de comunicación dixitais que están a cubrir a información cultural galega desde unha estratexia de guerra de guerrillas asentada, en preto da totalidade dos casos, no voluntarismo. Noticias, reportaxes, entrevistas e críticas de literatura poden atoparse en webs como Fervenzas Literarias, Letra en Obras, Biosbardia, Búsola ou Magazine Cultural Galego, ademais de nos espazos dedicados a cultura en medios dixitais como Praza Pública e Sermos Galiza ou no pouco que resiste na versión online das seccións culturais da prensa en papel.

\section{A ORIXE: OS BLOGS}

Aínda que a cultura galega comezara xa a atopar acubillo en Internet antes do estalido da crise, conxuntural e estrutural, das empresas de comunicación, foi a dinámica propia do chamado «blogomillo» a que a amparou. «Hai dez anos, o 2 de xaneiro de 2005, comezamos Santiago Jaureguízar e eu cos nosos blogs. Fomos, así, dos primeiros. Antes de nós viñeran Xabier Cid, María Yáñez, Manolo Gago ou Fran Alonso. Era o comezo do blogomillo», lembra Manolo Bragado, director de Edicións Xerais e creador de Brétemas, un dos blogs máis asentados do país. Tamén tivera grande acollida, neste sentido, o Lándoas do profesor Arturo Casas.

Os blogs de crítica literaria sitúanse, en efecto, entre os máis desenvolvidos. O Ferradura en tránsito de Xosé Manuel Eyré, o Criticalia de Armando Requeixo, o Caderno da Crítica de Ramón Nicolás, o Novenoites de Francisco Martínez Bouzas, o Bouvard e Pécuchet de Manuel Rodríguez Alonso, o Trafegando Ronseis de Gracia Santorum e Anxo Fernández, o Brabádegos de Romina Bal ou o da plataforma A Sega son algúns dos máis coñecidos na actualidade. Algúns deles serven tamén de repositorio das críticas publicadas polos seus autores en revistas e periódicos

en papel. É o caso de Armando Requeixo, que escribiu ou escribe no ProTexta de Tempos Novos, nos xornais do grupo Prensa Ibérica (Faro de Vigo, La Opinión) ou nos de La Capital.

Entre a información, a crítica e a creación literaria móvense moitos outros, creados boa parte deles por escritores e escritoras, como $O$ Porto dos escravos, de Mario Regueira; Versos e Aloumiños, os dous de Antonio García Teijeiro; 
A canción do náufrago, de Francisco Castro; A noite branca, de Francisco X. Fernández Naval; As crebas, de Miro Villar; As escollas selectivas, de Suso Díaz e Maripaz Paz; O levantador de minas, de Alfredo Ferreiro; Tomando notas nunha escola para resentid@s, de Gonzalo Hermo; ...mmmm..., de Estíbaliz Espinosa, ou o blog de Agustín Fernández Paz, entre outros.

Creación e xornalismo de opinión encóntranse tamén nos blogs de xornalistas como Fran P. Lorenzo (Un país en lata) e Santiago Jaureguízar (Cabaret Voltaire). Pero o mundo das webs de información e/ou crítica cultural non se esgota na literatura. De música pódense salientar o GZmúsica ou Músicaengalego; de cinema, o Acto de Primavera de Xurxo González, Óscar Sánchez (Martin Pawley) e José Manuel Sande, e, de teatro, Teatrogalego, de Carla Capeáns, ou Teatro Crítico Universal, de Manuel Xestoso, Camilo Franco, Roi Vidal, Inma López Silva e Afonso Becerra, sen esquecer revistas de arte como Plétora, de María Marco, Ania González e Horacio González.

\section{A PRENSA DIXITAL}

A cultura non foi nunca prioridade na maioría dos medios de comunicación presentes no país. Houbo excepcións, na prensa que, por cuestións de liña editorial -como o xornal Galicia Hoxe, o Xornal de Galicia, A Nosa Terra, Vieiros ou a delegación galega de El País-, si se amosaron máis sensibles a esta cuestión. Mais a tendencia xeral foi e é relegar a cultura á reserva de suplementos culturais de calidade variable -poden salientarse, nese aspecto, o Fugas de La Voz de Galicia, que recentemente absorbeu o Culturas, o Faro da Cultura do Faro de Vigo ou o Nordesía do Diario de Ferrol-; mentres a sección propia ou ben non existe ou ben se mimetiza con sociedade, lecer, axenda, tendencias, servizos e espectáculos televisivos. En moitos casos, tamén, aparece tanta ou máis información cultural nas páxinas de local ou nos suplementos de fin de semana que nunha área específica.

As empresas tentan xustificar a desatención á cultura co argumento de que non existe demanda. E se cadra a literatura non «vende» tanto como os partidos de fútbol, mais tampouco incrementan as vendas as múltiples roldas de prensa de nulo contido informativo que se cobren para que quen reparte subvencións e asina convenios poida saír, día tras día, na fotografía. A información cultural pode servir tamén á mellora da imaxe de marca -e, ás veces, á lexitimación social- duns medios hoxe noqueados non só pola crise económica, senón pola de credibilidade, consecuencia en moitos casos da súa autoinmolación ao renunciar a actuar como tales e converterse en plataformas propagandísticas.

Mais tomar en serio a cultura galega -ou mesmo a cultura de calquera outra parte do mundo- podería alterar o ADN de boa parte dos medios do país, para os que a cultura galega só se pode entender como un apéndice subordinado e dependente da cultura en castelán e inglés sancionada polas televisións de maior audiencia e servida polas axencias de noticias. Alén diso, adoptar unha liña crítica coa política lingüística e cultural da Xunta de Galicia pode ameazar a continuidade das subvencións. Ao mesmo tempo, a cultura non deixa de ser entendida como unha cuestión superflua, unha marca de clase para exhibir en certos espazos ou, mesmo, un problema para as elites sociais, económicas e políticas, ás que os medios de maior influencia representan e ás que as propias elites culturais, na súa maioría ideoloxicamente situadas á esquerda e co galeguismo, restan lexitimidade simbólica.

Na prensa dixital, a liña editorial -e outros factores, pois por exemplo El Mundo tivo unha delegación de Galicia que prestaba bastante atención á cultura e en galego- marca diferenzas. En Pontevedra Viva, a cultura é subliñada nun espazo específico da portada, como os deportes. En Mundiario, a moi escasa información cultural aparece inserida na sección de sociedade, como no Galiciaé -que noutro tempo si se distinguiu por publicar boas reportaxes e entrevistas de cultura-, mentres que en Noticias Galicia conta con sección propia, como en Galicia Dixital ou en Adiante Galicia. Máis e mellor atención recibe, porén, en Noticieiro Galego -cunha axenda cultural destacada e non tan dependente das notas de prensa- ou en Diário Liberdade. En canto ás cabeceiras integradas na Asociación de Medios en Galego, non sempre o discurso de defensa do idioma se corresponde coa relevancia concedida, na 
práctica, á información cultural. Si é así, por exemplo, no Que Pasa na Costa ou no Galicia Confidencial -co seu Tendencias-, aínda que en todos eles a primacía se sitúa, en canto ao volume da información publicada, máis en política, economía e sociedade que na cultura.

A cultura figura nunha posición especialmente destacada no proxecto de Praza Pública e no de Sermos Galiza, aínda que este último reserva os temas tratados con maior profundidade para o semanario en papel, do mesmo xeito que Praza Pública -malia que non sempre- edita as reportaxes e entrevistas máis elaboradas na fin de semana. «A cultura, a política e os movementos sociais son os tres piares básicos de Praza», apunta Marcos Pérez Pena, responsable da información cultural neste portal. Sermos conta, neste momento, con tres redactores, mais o director e os colaboradores. Ao ver da encargada de cultura, Carme Vidal, a importancia recoñecida á información cultural é cuestión «de liña editorial» e considerala unha prioridade «forma parte da tradición da prensa nacionalista».

\section{AS WEBS ESPECIALIZADAS}

Mais a prensa dixital, malia o esforzo realizado nese sentido pola máis comprometida coa lingua e coa cultura do país, non consegue cubrir a información cultural cun volume e cun grao de elaboración suficientes. É por iso que fica espazo para webs especializadas, como o portal de noticias culturagalega.gal, do Consello da Cultura Galega, que no seu recentemente estreado redeseño semella pretender reforzar os xéneros máis reflexivos como a reportaxe e a entrevista. As novas do mundo do libro nuclean os contidos de Fervenzas Literarias ou de Letra en Obras, dúas das webs veteranas do panorama cultural galego.

Fervenzas Literarias naceu nun terreo case ermo en 2006-2007 -no que pouco máis había que o Cartafol de Libros de Vieiros, o portal de literatura do Consello da Cultura Galega Lg3, BIVIR da Asociación de Tradutores Galegos, a Biblioteca Virtual Galega da Universidade da Coruña e algúns blogs. Ademais, sinala o seu fundador, Nacho Alonso, "as editoriais decatáronse da importancia de estar na rede, como os organismos e institucións, colectivos e asociacións literarias, fundacións, librarías ou bibliotecas».

Letra en Obras comezou a súa andaina no ano 2011 por iniciativa de Ramón Villar, Roberto Noguerol e Pablo García. «O obxectivo era crear un blog de literatura para visibilizar a xente nova. Publicamos noticias e algunha entrevista, pero Letra en Obras é máis ben unha web de artigos de opinión», conta Villar. A vocación xornalística si é clara no Magazine Cultural Galego ( $M_{-}$), web de entrevistas en profundidade, reportaxes e crónicas. A súa finalidade non é, porén, nin dar primicias nin repetir as novas que xa recolle a prensa, senón afondar nunha escolma persoal de temas, sen someterse necesariamente ao pulso da actualidade. $M_{-}$pretende tamén servir como proba da cara a unha posible versión avanzada, máis achegada a unha revista dixital profesional, xestionada colectivamente, máis especializada e concibida non só para o público galego.

Biosbardia foi tamén impulsada por xornalistas, neste caso procedentes d'A Nosa Terra e outros medios: César Lorenzo Gil, Manuel Veiga, Xosé Enrique Acuña e Xan Carballa, cos que colabora, entre outros, o crítico Xesús González Gómez. «É unha web xornalística, centrada no libro. 0 cerne son as entrevistas, que é o que máis debate crea. Mais tamén a crítica. E non un repositorio de críticas publicadas noutros medios, nin só reseñas, senón críticas que dean leña», sinala César Lorenzo.

Nesta mesma liña da procura de nichos de mercado pouco explorados sitúanse Criaturas ou Disquecool, así como o blog de crítica Teatro Crítico Universal. Criaturas é unha publicación dedicada á literatura infantil e xuvenil fundada coa vocación de converterse na «casa común» de «todos os axentes que interveñen na LIX». Coordinada polo poeta, deseñador e filólogo Daniel Landesa e a escritora Ledicia Costas, está a ter «unha acollida mellor da que esperabamos», indica esta última.

Disquecool foi lanzada por un equipo de catro xornalistas, un fotógrafo e unha programadora. «A idea era crear unha revista de tendencias para visibilizar o cool que se estaba facendo en Galicia», explica Raquel C. Pico. 
Teatro Crítico Universal, fundado por dous xornalistas, dous críticos e profesores e un dramaturgo e director teatral, responde, pola súa banda, á progresiva eliminación dos espazos dedicados pola prensa á crítica teatral. «Formamos parte da Revista Galega de Teatro, pero funcionamos de xeito autónomo. Cando comezamos, na Mostra de Ribadavia, a resposta foi moi boa. Estaba claro que había unha parte da sociedade, que son os profesionais das artes escénicas, que botaba de menos a crítica. O público xa é máis difícil de conquistar: non somos un país de moita asistencia ao teatro nin de elevados índices de lectura. Ademais, o mundo cultural está moi desestruturado», sostén Manuel Xestoso.

Vivir na Coruña é outra das webs especializadas que están a funcionar mellor. Ademais dunha completa axenda, este portal, xestionado pola xornalista Lucía Pita e o sociólogo Daniel Fernández, ofrece noticias, entrevistas e pequenas reportaxes. «A idea é socializar a cultura, porque moitas ramas da mesma non estaban a chegar a un público amplo», indica Fernández. Existen, no país, outras axendas como Tempodelecerourense, Vouaxenda, Compostelacapitalcultural, Compostela Hoxe, VigoCultura e Coruñacultura, ademais de webs que realizan tamén esa función como a da Asociación de Escritores e Escritoras en Lingua Galega (AELG).

\section{EXISTE DEMANDA? O FUTURO}

Mais a gran pregunta é se habería xeito de rendibilizar, nun sentido económico, estes proxectos ou, polo menos, crear algún tipo de plataforma común que permitise incrementar a súa visibilización a partir do intercambio de contidos; ou mesmo crear un medio de comunicación dixital novo, especializado en cultura, que xuntase polo menos parte dos esforzos ata agora consagrados á guerra de guerrillas que é a comunicación do ámbito cultural en Internet.

Raquel C. Pico amósase contundente: «vamos deixar claro que isto non dá cartos. Dicir o contrario sería enganar a xente», sinala. Mais nin ela nin a maioría dos profesionais consultados renuncian á idea de conseguir o financiamento necesario para, polo menos, poder remunerar as colaboracións. Ocorre que, cunhas audiencias tan fragmentadas, o acceso ao mercado da publicidade é moi limitado. «Ademais, non temos un Google Acts en galego. Para min, esa sería a prioridade», indica Pico. Outra opción é o ofrecemento de servizos especializados.

Semella relevante, ao respecto, incrementar as audiencias. O cal podería ser posible, quizais, ollando tamén a outros países. «A nosa cultura esponxa, as relacións tanxenciais con Brasil, Cuba, Irlanda... son unha vantaxe. Internet parece inventada para os galegos, porque Galicia é unha rede que se estende por todo o mundo. Aínda que hai que ter en conta que que te lean fóra é unha cuestión de calidade dos contidos, non de semellanzas lingüísticas. Por outra banda, a presenza do noso idioma é porcentualmente moito maior en Internet que noutros ámbitos», cre o decano do Colexio Profesional de Xornalistas de Galicia, Xosé Manuel Pereiro.

En confluencia con el, Manuel Bragado pensa que pode existir espazo para «unha revista dixital cultural galego-portuguesa. Na Internet galega pode haber unhas 10000 ou 15000 persoas interesadas na cultura. É un público interesante, pero non suficiente para soster un medio. Por iso opino que habería que ir cara a unha publicación plurilingüe: en galego-portugués, castelán e inglés», reflexiona. Un proxecto que está e explorar xa a resposta da Iusofonía é Palavracomum, revista de textos de creación e artigos de reflexión sobre temáticas variadas, lanzada por Alfredo Ferreiro, Tati Mancebo e Ramiro Torres. «O noso obxectivo é crear un lugar de encontro de Galiza coa lusofonía, un proxecto galego-lusófono de intercambio de ideas e de artes», salienta Ferreiro.

Malia que Palavracomum tampouco acadou polo momento un número de visitas maior que o do resto de webs culturais citadas, que contan cuns 10000 ou 12000 visitantes ao mes -menos que os blogs máis veteranos, que poden superar longamente os 1000 ao día-, o seu volume de lectores e lectoras sitúase tamén por debaixo do das noticias culturais dos medios dixitais en galego. Só por poñer un exemplo, no mes de marzo, no Sermos Galiza, unha entrevista coa cantante Sés superou as 4500 visitas, mentres que novas relativas a un vídeo de Enrique 
Iglesias gravado en Galicia pasaron das 20 000. Fóra dese tipo de temáticas máis polémicas, non é raro tampouco que nas webs especializadas os artigos máis vistos cheguen ás 3000 ou 4000 visitas.

Nunhas xornadas recentes, realizadas no Consello da Cultura, o director de culturagalega.gal e profesor da Facultade de Ciencias da Información Manuel Gago situaba, realizando un cálculo a partir dos datos das contas das redes sociais, nunha cifra aproximada de 16000 os lectores e lectoras da información cultural en Galiza, que poderían aumentar a uns 18000 ou 20000 se se consideran os seguidores dos principais medios dixitais. "Se conseguimos subir aos 50 000, si poderiamos falar de viabilidade en canto a ingresos por publicidade», comenta. Aclara, porén, que máis que un público para cultura, existen audiencias segmentadas por áreas temáticas.

Concorda con el, neste último aspecto, o xornalista Camilo Franco, que formula outra cuestión. Porque -explica- «unha boa medida da industria cultural galega, caso de que exista, é se sería quen de manter un medio de comunicación que fose o seu aliado. Hai talento e profesionais para crear un medio cultural de calidade. 0 que non sabemos é se hai, realmente, demanda de periodismo cultural. Porque se nace un medio e os profesionais e empresas da cultura, que son os primeiros que deberían estar interesados en sostelo, non responden, é que se cadra non o queren, na práctica. Ocorre que, como culminación dos últimos trinta anos de cultura galega, hai profesionais, mais non acaba de aparecer o público. $\mathrm{E}$, se non hai medios, tamén é difícil que haxa público. Da mesma maneira que, se non hai público, é complicado que haxa medios culturais».

Nese sentido, cumpriría tamén revisar a maneira en que se está a comunicar cultura. A revista Luzes, por exemplo, está a enfocala dun xeito transversal, sen restrinxir a súa presenza á sección cultural. Porque a cultura debe figurar tamén, ademais de en áreas específicas, na información diaria fornecida polos medios -telexornais e programas de entrevistas que chegan ao público máis heteroxéneo, por exemplo. 0 nivel de escolla temática -máis alá da axenda do día, das noticias proporcionadas polas axencias e da promoción de produtos concretos que a cada profesional da cultura lle poida interesar en cada momento- mais a calidade e estilo na escrita distinguiron a ese respecto suplementos culturais como o Luzes de El País.

No informe A comunicación en Galicia 2013, o escritor Xosé A. Neira Cruz sinalaba a escasa variedade de formatos na presentación dos contidos sobre literatura na rede, é dicir, a falta de propostas novas que revisen os xeitos de contar. Referíase, neste sentido, á limitada aposta por un xornalismo de opinión «con afáns creativos e innovadores» ou, mesmo, á falta de columnas literarias, nun contexto en que a porcentaxe de escritores e escritoras nas columnas é elevada. Así, se cadra, parte do futuro da prensa dixital tamén deberá camiñar por esa senda: bos cronistas literarios e bos columnistas que non desprecen o xornalismo como irmán menor da literatura. Outro perigo que afastar é reducir a información cultural á recensión ou á crónica máis ou menos compracente, ou limitar a concepción do xornalismo a unha sorte de activismo cultural, contribuíndo, así, a reforzar a percepción social daquel como unha profesión prescindible ou como un entretemento para o tempo libre. 